\title{
NEONICOTINOIDS IN GROUNDWATER: PRESENCE AND FATE IN TWO DISTINCT HYDROGEOLOGIC SETTINGS IN ONTARIO, CANADA
}

\author{
by \\ David Chalker Browne
}

\begin{abstract}
A Thesis
presented to

The University of Guelph

In partial fulfillment of requirements

for the degree of

Master of Applied Science

in

Engineering
\end{abstract}

Guelph, Ontario, Canada

(c) David Chalker Browne, September, 2017 


\title{
ABSTRACT
}

\section{NEONICOTINOIDS IN GROUNDWATER: PRESENCE AND FATE IN TWO DISTINCT HYDROGEOLOGIC SETTINGS IN ONTARIO, CANADA}

\author{
David Chalker Browne \\ Advisor: \\ University of Guelph, 2017 \\ Dr. Jana Levison
}

Neonicotinoids are a group of insecticides that are commonly used in agriculture throughout the world. Despite their widespread use, there are significant knowledge gaps related to the presence and fate of neonicotinoids in groundwater. This research consists of a seasonal groundwater sampling regime, soil sampling, a crop survey, and mathematical modelling exercises which aim to test the environmental parameters governing the transport of clothianidin, imidacloprid, and thiamethoxam to groundwater in two distinct hydrogeologic settings. Both of these research sites are located in Ontario, Canada: one comprises an unconfined, sandy quaternary aquifer while the other consists of a fractured, crystalline bedrock aquifer (Canadian Shield) under a thin layer of overburden. Groundwater sampling was conducted using between 18 and 26 monitoring intervals at each research site in April 2016, July 2016, August 2016, November 2016, and April 2017. All laboratory analysis was conducted using the LC-ESI(+)-MS/MS at the University of Guelph Ridgetown Campus. Results from groundwater sampling found the neonicotinoids clothianidin, imidacloprid, and thiamethoxam with maximum concentrations and detection frequencies above the level of quantitation of $2.09 \mu \mathrm{g} / \mathrm{L}, 0.7 \mu \mathrm{g} / \mathrm{L}, 0.46 \mu \mathrm{g} / \mathrm{L}$, and $2.2 \%, 0.9 \%, 1.3 \%$, respectively. Clothianidin peaked at four monitoring intervals in August 2016 (approximately three months after seed sowing and two months prior to harvesting). Imidacloprid was found at low concentrations that were marginally above the level of quantitation during July and August sampling. Thiamethoxam was found at one monitoring interval in Lanark County during both spring freshet (April) sampling rounds. Mathematical modelling revealed that under similar environmental conditions, clothianidin and thiamethoxam are released in a similar pattern that resembles a pulse. The delayed release of thiamethoxam to one monitoring interval in Lanark County was likely due to unusually low permeability overburden near the well. In both of these hydrogeologic settings, modelling revealed that the transport of both clothianidin and thiamethoxam is dominated by processes in 
the vadose zone. Future research into this subject should focus on how neonicotinoids behave within different climatic and hydrogeologic settings outside of Ontario, Canada. 


\section{Co-Authorship}

David C. Browne is the primary author of this text. Chapter two was completed as a literature review manuscript that has been submitted for publication to the Water Quality Research Journal of Canada. Dr. Jana Levison, Dr. Victor Limay-Rios, and Dr. Kent Novakowski are coauthors of chapter two. Chapter four is written as a manuscript that details all research associated with this thesis. It will be submitted for publication with Dr. Levison, Dr. Limay-Rios, Dr. Novakowski, and Dr. Art Schaafsma as coauthors. 


\section{Acknowledgements}

First of all, thank you to my supervisors for providing me with advice and guidance over the past two years. Primarily, thank you to Dr. Jana Levison for leading this project and taking me on as a Masters student. Dr. Levison was always available to provide feedback on planning field work and various drafts of papers (even while on maternity leave in 2016). Dr. Victor Limay-Rios has been invaluable to this research in providing expertise on the properties of neonicotinoids and laboratory analysis techniques. Thank you to Dr. Kent Novakowski for providing reliable advice throughout the project, and in particular for the modelling portion of this research. And thank you to Dr. Art Schaafsma for giving the time to provide expertise on neonicotinoid use in Ontario.

Thank you to the Ontario Ministry of Food, Agriculture and Rural Affairs, along with the Ontario Ministry of Agriculture (OFA) for funding this project. Thanks to Karl Soetemans at the OFA for providing advice on the farmer survey. Norfolk County and Queen's University provided access to wells in Norfolk and Lanark County, respectively. Thank you to Graham MacDonald and Titia Praamsma for providing information on each site. And thank you Scott Gardner and Geof Hall for taking the time to accompany me to each site and show me where each well is located. I am also grateful for the hospitality shown towards me by Sonia Nobrega and the staff at the Queen's University Biological Station. They ensured I was well fed and taken care of during my field work in Lanark County. Thank you to Don, Carolyn, Heather, and in particular, Oreo Shilton for providing food and board during my field work in Norfolk County.

The staff at the School of Engineering enabled this project to run smoothly. Thank you to Ryan Smith and Joanne Ryks for providing access to labs, advice on lab experiments, and for allowing me to store hundreds of bottles and a dozen coolers in the water lab for the past year and a half. Thank you to Jenn McCreary for help in purchasing, returning, and repairing far too many groundwater pumps. Thanks to Matthew Kent, Joel Best, and Jeff Madge for IT help. Thank you to everyone who directly contributed to my project - in particular, thanks to Laura Perron and Heather Shilton for tolerating my ambitious daily schedule during field work (which often involved 
12 hour days on weekends in $40^{\circ} \mathrm{C}$ weather). Thanks to Laura, Scott Gardner, and Peter Bishop for help with GIS during my degree.

I really enjoyed being a TA for Urban Water Systems and Fluid Mechanics over the past two years. Thank you to Dr. Zoe Zhu, Dr. Syeda Tasnim, and Dr. Bill Van Heyst for hiring me and thanks to all the students who came to my tutorials.

When I moved to Guelph, I was quite lucky to find a great group of friends within a few weeks. Thank you to Ryan, Amy, Steve, Shoaib, Peter, Ellen, Elisha, Etta, Richard, Scott, Yvonne, Mansour, Sarah, Joel, and anyone else who I forgot. And while I'm here, thanks to all of my buddies back home in St. John's.

I want to finish by thanking my family. It is a bit of an understatement to say I would not be in a position to submit this thesis without my parents. So thanks to Mom and Dad for supporting me throughout my stressful undergrad and in my decision to leave home for a school halfway across the country. Thank you to Paul, Michael, and Maria for keeping in touch when l've been too distracted to reach out. Lastly, thank you Heather for your work in keeping me happy during the long hours that are associated with a thesis on neonicotinoids. 


\section{Table of Contents}

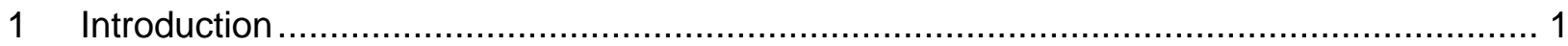

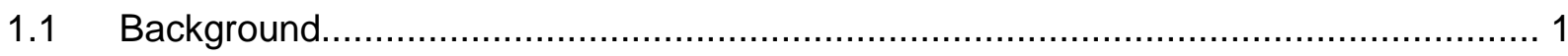

1.2 Scope and Specific Objectives ........................................................................ 2

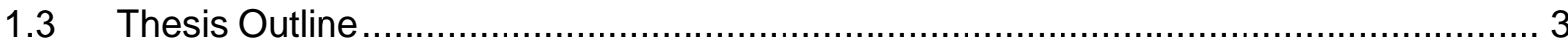

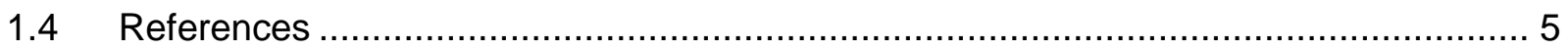

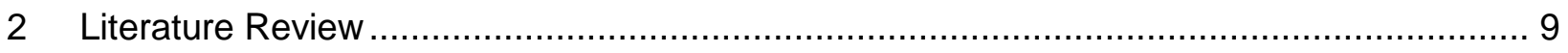

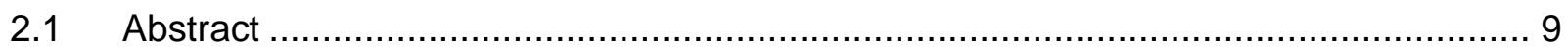

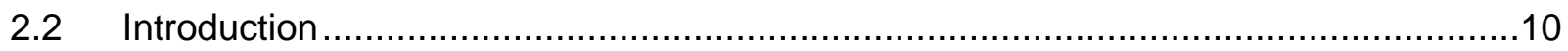



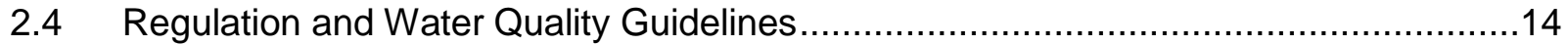

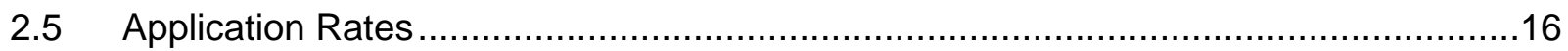

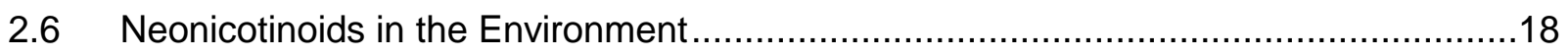

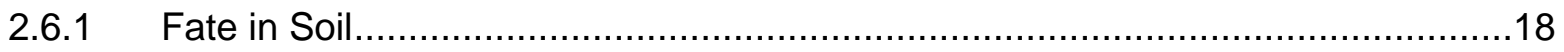

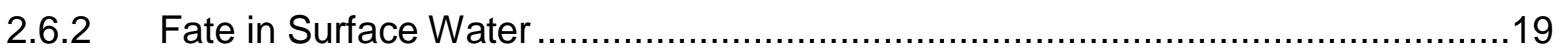

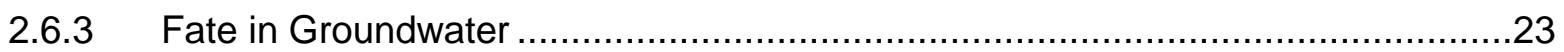

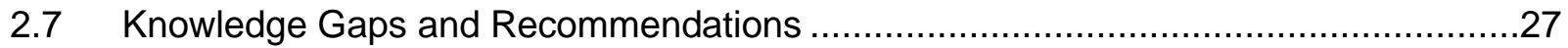

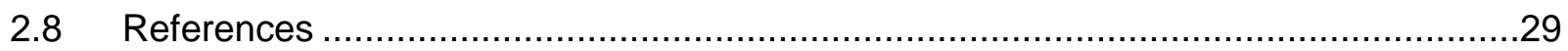

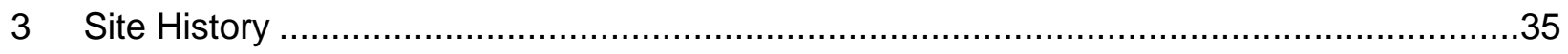

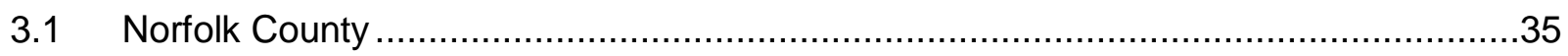

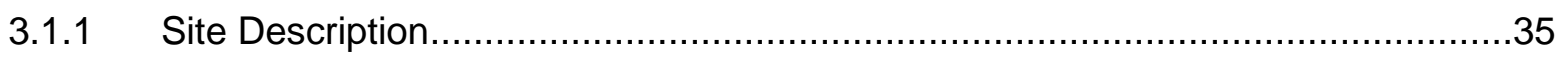

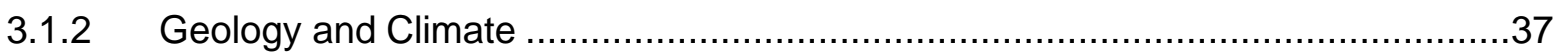

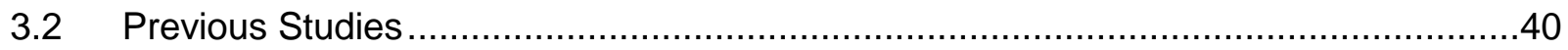

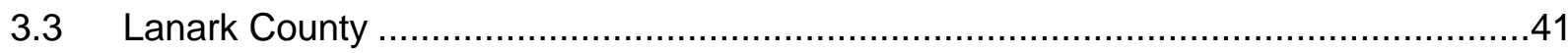

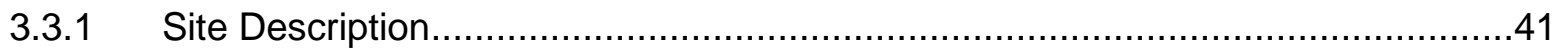

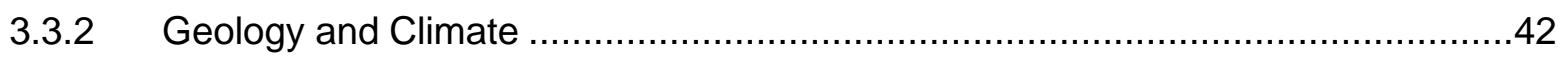

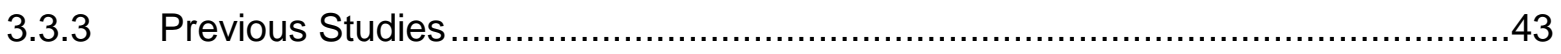




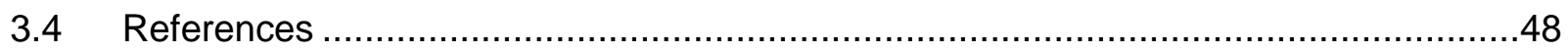

4 Neonicotinoids in Groundwater: Presence and Fate in Two Distinct Hydrogeologic Settings

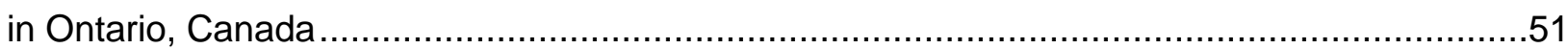

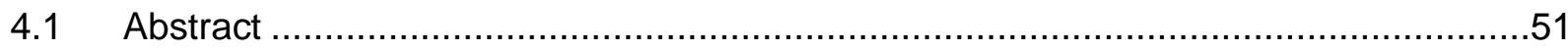



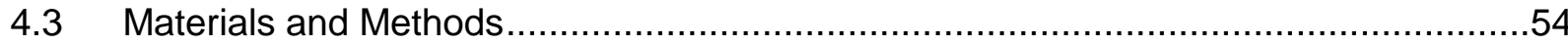

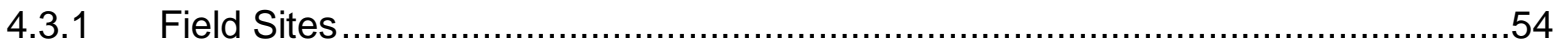

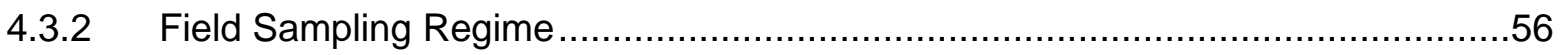

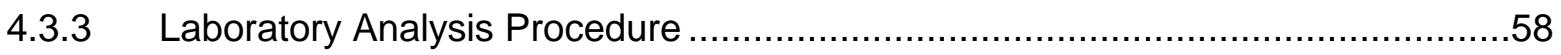

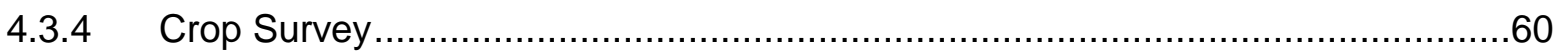

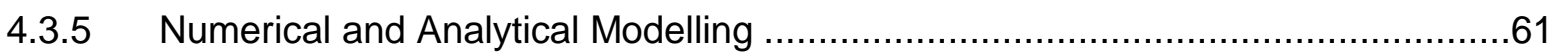

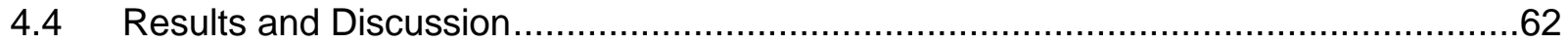

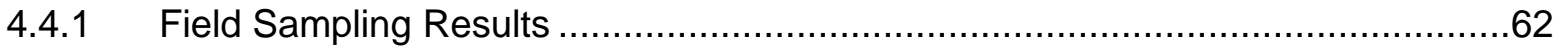

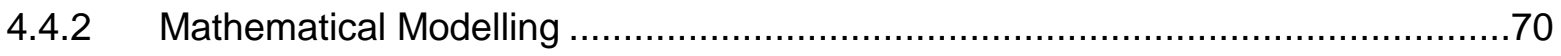

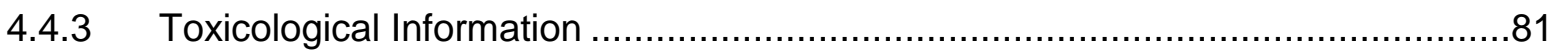

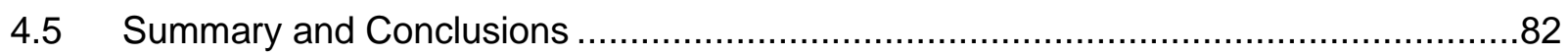

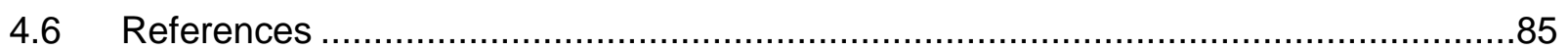

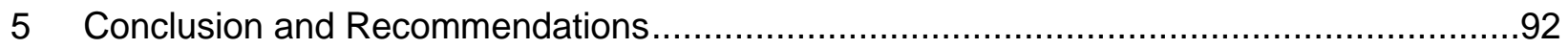

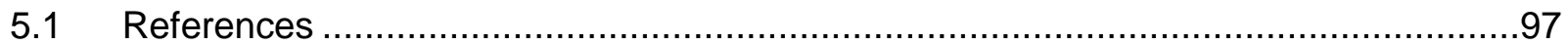




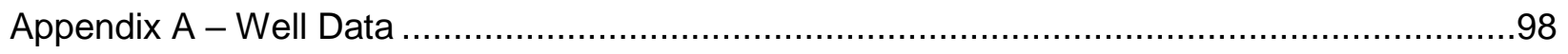

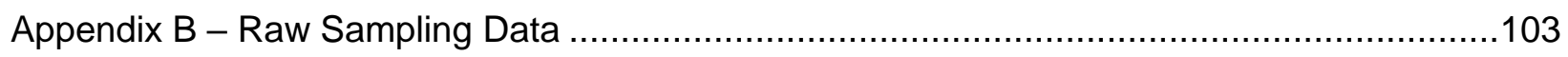

Appendix C - Pressure Transducer Data .............................................................. 132

Appendix D - Farmer Survey Questionnaire ............................................................ 141

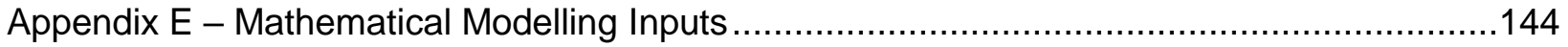

Appendix F - Soil Sampling Locations ..................................................................... 170

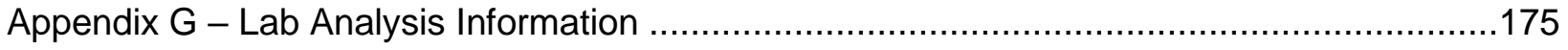

Appendix H - Field Parameters and Lab Analysis Graphs ........................................177

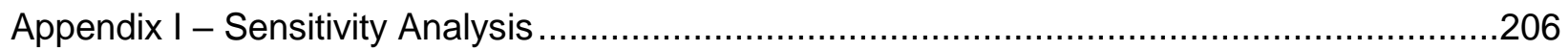




\section{List of Figures}

Figure 2.1: Conceptual diagram that depicts the current state of knowledge into the fate of neonicotinoids in groundwater and the environment. This diagram has been developed for the Ontario, Canada context. Clothianidin, imidacloprid and thiamethoxam are represented by CLO, $\mathrm{IMI}$, and THM, respectively. 28

Figure 3.1: The location of each research site in southern Ontario, Canada (upper image). Norfolk County, bottom left, is shown with monitoring wells that are referenced as 'LP'. LP20, LP21, LP23, and LP26 reside west of the domain and were not included in this study. The Lanark County research site, bottom right, is shown with the well cluster in a hay field enlarged in the bottom right corner. All wells in Lanark County are referenced as 'TW'. The elevation is contoured in metres above sea level at both research sites.

Figure 3.2: Location of the 26 multi-level Long Point Monitoring Wells in Norfolk County. Regional groundwater flow (indicated by the blue arrow) is derived from April 2016 static water levels. Digital elevation data is displayed in units of meters above sea level and was obtain from Natural Resources Canada (2017). 36

Figure 3.3: Generalized conceptual model of the central Norfolk Sand Plain, adapted from Marich (2010). Cross section is oriented from west to east.

Figure 3.4: Permeability of the quaternary geology within the confines of the Norfolk County study site (Ontario Geological Survey, 2010). Low permeability Port Stanley Till lies along the northwest extents of the study site, while the high permeability coarse-textured glaciolacustrine deposits dominate the central and southeastern limits of the region. The Paris Moraine is interpreted as a low permeability zone in the northeast corner while varied alluvial deposits acts a divide across the study region.

Figure 3.5: Location of 21 multi-level wells in Lanark County. Regional groundwater flow direction is eastward. Digital elevation data is displayed in units of meters above sea level and was obtained from Natural Resources Canada (2017). Regional groundwater flow (indicated by the blue arrow) was derived from April 2016 static water levels. 
Figure 3.6: Relative permeability of the Lanark County study site (Ontario Geological Survey, 2010). Low to medium-low permeability overburden dominates the study region with deposits of variable permeability visible throughout. 43

Figure 4.1: The location of each research site in southern Ontario, Canada (upper image). Norfolk County, bottom left, is shown with monitoring wells that are referenced as 'LP'. LP20, LP21, LP23, and LP26 reside west of the domain and were not included in this study. The Lanark County research site, bottom right, is shown with the well cluster in a hay field enlarged in the bottom right corner. All wells in Lanark County are referenced as 'TW'. The elevation is contoured in metres above sea level at both research sites.

Figure 4.2: 2016 crop map of research sites in Norfolk County (top) and Lanark County (bottom) (Agriculture and Agri-Food Canada, 2017). Wells with detections above the LOQ are show with a green background. The local groundwater flow direction is contoured from static water levels retrieved in April 2016 and is measured in metres above sea level.

Figure 4.3: Neonicotinoid and nitrate concentrations at monitoring wells in Norfolk and Lanark County. A) Clothianidin peaks at LP-MW-02D and LP-MW-11D occur roughly one month after nitrate peaks. This is likely due to the application of clothianidin as a seed dressing several weeks after manure (a possible nitrate source in this instance) is spread on agricultural fields. Precipitation and the groundwater level at LP-MW-02M is shown against typical crop planting and harvesting times in Norfolk County. The groundwater level at LP-MW-02M was found to closely resemble the level at LP-MW-02D during static water level monitoring (Appendix B Raw Sampling Data). Groundwater level data at LP-MW-11D are unavailable over large periods throughout the sampling regime due to the water level falling below the pressure transducer. B) Clothianidin, thiamethoxam, and nitrate-N peaks occur at TW17 during the spring freshet. Groundwater level data at TW17 are unavailable between April and July of 2016. Precipitation data are shown against typical crop planting and harvest times in Lanark County.

Figure 4.4: Deposit permeability map for the Lanark County research site (Ontario Geological Survey, 2010). Note that the relative overburden permeability near TW17 ranges from low to low-medium. This likely accounts for the delayed release of nitrate, clothianidin, and thiamethoxam from the overburden to the groundwater in that area 
Figure 4.5: Conceptual diagram of the modelled 1D domain at LP-MW-02. For the Hydrus 1D model, precipitation, evapotranspiration, and runoff act as the upper boundary conditions, while the groundwater level from a pressure transducer is used as the lower boundary condition. Outputs from the Hydrus model at the groundwater table were input into the Ogata-Banks solution in order to assess the horizontal distance that clothianidin will typically travel in a sandy, unconfined aquifer. .74

Figure 4.6: Breakthrough curves for clothianidin in the LP-MW-02 saturated zone. These were determined using the Ogata-Banks solution (Craig, 2014; Ogata and Banks, 1961; Van Genuchten, 1981) and reveal that clothianidin concentrations found in this well likely originated from nearby agricultural activities. The slug input $(0.15 \mu \mathrm{g} / \mathrm{L}$ over 30 days $)$ is an approximation of the output from the Hydrus 1D vadose zone model.

Figure 4.7: Conceptual model of clothianidin (CLO) and thiamethoxam (THM) movement through the unconfined, quaternary aquifer of Norfolk County. Mathematical modelling revealed that thiamethoxam is released gradually to the saturated zone before reaching a peak groundwater concentration. The peak thiamethoxam concentration occurs prior to that of clothianidin. The transport of both neonicotinoids is dominated by processes in the vadose zone where insignificant degradation occurs. Any concentrations of these contaminants that are found in groundwater are likely to originate from nearby agricultural activities. .76

Figure 4.8: Conceptual diagram of the modelled 1D domain at TW17. In Hydrus 1D, precipitation, evapotranspiration, and runoff act as the upper boundary conditions, while free drainage is used as the lower boundary condition. The output from the Hydrus 1D model is used as an input to the analytical solution for one-dimensional advection with matrix diffusion (Sudicky, 1988; Sudicky and Frind, 1982). This fracture transport equation is adapted from the Tang solution (Tang et al., 1981)

Figure 4.9: Breakthrough curves of thiamethoxam through a single fracture in Lanark County. These curves were calculated using the analytical solution for one-dimensional advection with matrix diffusion (Sudicky, 1988; Sudicky and Frind, 1982; Tang et al., 1981). The input concentration to this model was $0.065 \mu \mathrm{g} / \mathrm{L}$. These curves reveal that once thiamethoxam reaches a fracture, it can travel several meters within a few hours. 
Figure 4.10: Conceptual model of clothianidin (CLO) and thiamethoxam (THM) transport to the fractured bedrock aquifer of Lanark County. Neonicotinoid movement through fractures is represented by the yellow dotted line. Due to the low permeability of the overburden near TW17, both neonicotinoids are relatively immobile in the topsoil until the high downward water flux associated with the spring freshet. The concentrations of both neonicotinoids are likely reduced through soil degradation over the 10 to 12 -month period prior to leaching. It is also possible that a portion of thiamethoxam is metabolized into clothianidin during this period. Once either neonicotinoid reaches a fracture, it are rapidly transported (on an order of days) through a fracture. It is likely that these neonicotinoids are further diluted due to the high volume of water in the $24 \mathrm{~m}$ open well.

Figure 4.11: Hydrus 1D graphical outputs from LP-MW-02 and TW17. A) The field detections for clothianidin (LP-MW-02D) and thiamethoxam (TW17) are contrasted with the modelled concentrations for those same wells. The modelled clothianidin peak at the groundwater table occurs roughly one month after the field peak in groundwater. Model simulations were unable to reproduce the freshet thiamethoxam peak that occurred at TW17. B) Clothianidin and thiamethoxam concentrations at the groundwater table at LP-MW-02. Thiamethoxam appears to be released in a similar, but more gradual manner than clothianidin at this location. This may result in thiamethoxam concentrations that fall below the LOQ in the field. C) Clothianidin and thiamethoxam concentrations at the groundwater table at TW17. The small domain $(0.6 \mathrm{~m})$ results in a similar release of both neonicotinoids at this location. D) The transport of clothianidin and thiamethoxam at LP-MW-02 at the groundwater table, $2.5 \mathrm{~m}$ above the groundwater table, and $5 \mathrm{~m}$ above the groundwater table. The peak magnitude of both neonicotinoids decreases by half with each depth increase. 


\section{List of Tables}

Table 2.1: Application rates of neonicotinoids in Ontario (Ontario Ministry of Agriculture and Food and Rural Affairs, 2016). Unless otherwise stated, neonicotinoids are applied as a seed dressing. All neonicotinoids listed in this table are registered by the Government of Canada and classified by the Ontario Ministry of Environment and Climate Change. This means the neonicotinoids have been authorized for use in Ontario after the evaluation of scientific data to ensure the product is effective and has acceptable environmental risks.

Table 2.2: Physical properties of neonicotinoids (Bonmatin et al., 2015; Hladik et al., 2014; Morrissey et al., 2015).

Table 2.3: Published ecological quality reference values (average and maximum) for neonicotinoids in freshwater environments. Average (acute) and maximum (peak) values are compared. This table was adapted from Morrissey et al. (2015).

Table 2.4: Active Ingredient of neonicotinoids sold in Canada in 2008, 2011 and 2014 .16

Table 2.5: Active ingredient of neonicotinoids in southwestern Ontario (Schaafsma et al., 2016).

Table 2.6: Application rate of neonicotinoid seed treatments in Ontario (Stewart et al., 2013)...17

Table 2.7: Summary of field studies about neonicotinoids in soil and soil leachate. DF, LOD and, LOQ refer to Detection Frequency, Level of Detection, and Level of Quantitation, respectively. Peak is the maximum concentration that was recorded during each study.

Table 2.8: Summary of field studies on neonicotinoids in surface water bodies. DF, LOD and, LOQ refer to Detection Frequency, Level of Detection, and Level of Quantitation, respectively. Peak is the maximum concentration that was recorded during each study. 21

Table 2.9: Summary of field studies on neonicotinoid concentrations in groundwater. DF, LOD and, LOQ refer to Detection Frequency, Level of Detection, and Level of Quantitation, 
respectively. Peak is the maximum concentration that was recorded during each study. Aquifer type was only specified in Bortoluzzi et al. (2007). .26

Table 3.1: Sedimentary packages across the central Norfolk Sand Plain, as per Marich (2010).

Table 3.2: Summary of all studies performed using the Tay River wells in Lanark County 44

Table 4.1: Physical properties of clothianidin, imidacloprid, and thiamethoxam (Bonmatin et al., 2015; Hladik et al., 2014; Morrissey et al., 2015). Note that clothianidin and thiamethoxam are significantly more persistent in soil compared to water.

Table 4.2: Incidence of six neonicotinoids, two fungicides, two herbicides, and one ryanoid in 228 water samples collected from Long Point Monitoring Wells $(n=122)$ and Tay Wells $(n=104)$ between 2016 and 2017. Two additional samples were taken from the Tay River near TW4 and TW21 in August 2016. These two samples had no pesticide detections above the LOD. The LOD and LOQ vary for each round of samples and their standard deviation was calculated directly from calibration curves.

Table 4.3: List of clothianidin, imidacloprid, and thiamethoxam detections and their detection frequency. All neonicotinoid detections above the LOQ are listed with the concentration shown in brackets.

Table 4.4: Typical application rates of neonicotinoids in Norfolk and Lanark County. The types of seed dressings and number of seeds per acre are based on responses to the farmer survey (Appendix D - Farmer Survey Questionnaire). Treatment rates are based on information from OMAFRA (2016) and PMRA Pesticide Labels (Syngenta Canada Inc., 2016). Note that application rates associated with soybeans are larger than rates associated with maize crops as a result of seeding rate.

Table 4.5: Results from sieve, hydrometer, and loss-on-ignition tests for the overburden near LP-MW-02 and TW17. Concentrations of clothianidin and thiamethoxam were measured for the bulk reference core and used as inputs to the Hydrus 1D models (Forero, 2017). .70 
Table 4.6: Concentrations of clothianidin and thiamethoxam in the reference core (Forero, 2017). These concentrations were used as inputs to the Hydrus 1D models. The clothianidin concentration is higher than the concentration from July 2016 soil sampling at LP-MW-02 $(0.75 \mu \mathrm{g} / \mathrm{L})$, while the thiamethoxam concentration is lower than what was detected in the soil near TW17 in July $2016(1.01 \mu \mathrm{g} / \mathrm{L})$. Thiamethoxam concentrations in the reference core (Forero, 2017) are residual concentrations from the 2013 planting season. This is likely why the overburden near TW17 has higher thiamethoxam concentrations compared to what was found in August 2014 by Forero (2017)

Table 4.7: Key input parameters for the Hydrus 1D models at LP-MW-02 and TW17. Note that LP-MW-02 is composed of four quaternary material layers, whereas TW17 only includes the thin till over the fractured bedrock.

Table 4.8: Inputs for the analytical Ogata-Banks solution in the LP-MW-02 saturated zone. This model was used in order to determine the movement of the clothianidin pulse in groundwater within a sandy, unconfined aquifer. The Ogata-Banks solution was evaluated using the spreadsheet developed by Craig (2014) based on Van Genuchten (1981). .75

Table 4.9: Inputs to the analytical solution for one-dimensional advection with matrix diffusion. Fracture velocity was calculated according to the cubic law. There is minimal matrix diffusion in crystalline bedrock aquifers such as in the Tay River Watershed (Mutch et al., 1993). Fracture spacing was set at an unrealistically high number $\left(1.0 \times 10^{10}\right)$ in order to approximate flow through a single fracture.

Table 4.10: Toxicological endpoints are shown against the maximum concentrations of clothianidin, imidacloprid, and thiamethoxam that were detected in groundwater. Unless otherwise noted, all acute and chronic endpoints for honeybees, bumblebees, and solitary bees are $48 \mathrm{~h}$ LD50 and $10 \mathrm{~d}$ LD50 values, respectively. All aquatic invertebrate acute and chronic toxicological endpoints are 48 h EC50 and 21 d NOEC values, respectively. Maximum exposure rates for honeybees, bumblebees, and solitary bees are calculated assuming a maximum water consumption of $11 \mu \mathrm{L}$ of water at $35^{\circ} \mathrm{C}$ (Free and Spencer-Booth, 1958) with maximum neonicotinoid concentrations found in the field. This table is based on information found in European Food Safety Authority (2016a, 2016b, 2015) and Pesticide Properties Database (2017). 


\section{Introduction}

\subsection{Background}

Neonicotinoids are a group of insecticides that are commonly used in agriculture. These insecticides, most commonly applied as a seed treatment, reduce pest infestations and the prolificacy of plant disease at very low application rates (Kurwadkar and Evans, 2016). They are taken in by the roots of plants and transported to where they can act on feeding insects (Canadian Council of Ministers of the Environment, 2007). All neonicotinoids act as an agonist at nicotinoid acetylcholine receptors (nAChRs) within the central nervous system of target insects; once ingested by the insect, neonicotinoids cause paralysis and/or death (Canadian Council of Ministers of the Environment, 2007; Goulson, 2013; Matsuda et al., 2001).

The first neonicotinoid, imidacloprid, was introduced in 1991 by Bayer Crop Science Inc. (Maienfisch et al., 2001). Imidacloprid was followed by other first generation neonicotinoids nitenpyram, thiacloprid and acetamiprid in the mid-1990s (Maienfisch et al., 2001). Second generation neonicotinoids include clothianidin and thiamethoxam; the third generation is dinotefuran. These generations differ from each other in chemical composition - the first generation uses a chloropyridinyl moiety; the second generation uses a chlorothiazolyl group; and the third generation uses acetylcholine instead of nicotine (Sheets, 2010).

In the late 2000s, neonicotinoids started to come under global scrutiny due to contentious links between their use and the decline of both aquatic invertebrate and pollinator populations (Canadian Council of Ministers of the Environment, 2007; Girolami et al., 2009; Goulson, 2013; Miranda et al., 2011; Morrissey et al., 2015; Woodcock et al., 2017). International regulations that have been implemented target the three most popular neonicotinoids - clothianidin, imidacloprid, and thiamethoxam. On July 1, 2015, rules for the sale and use of neonicotinoid-treated seeds were introduced in Ontario, Canada. They stipulate certain actions with the target of an $80 \%$ reduction (compared to 2015 levels) of the number of acres planted with neonicotinoid-treated maize and soybean crops by 2017 (Government of Ontario, 2009). Federally, Health Canada's Pest Management Regulatory Agency (PMRA) is proposing a phase-out of all agricultural and many other outdoor uses of imidacloprid over three to five years (PMRA, 2016a). Additional PMRA reports on clothianidin and thiamethoxam are forthcoming. Other bans implemented around the world include a partial restriction on imidacloprid, clothianidin, and thiamethoxam use throughout the European Union. This two-year proposal came into effect in December 2013 and has been extended so that it remains in place as of publication date (European Commission, 2013). 
Due to these disputed impacts on non-target organisms, there has been extensive research on the presence of neonicotinoids in soil, dust, and surface water (Bonmatin et al., 2015; Fossen, 2006; Goulson, 2014, 2013; Limay-Rios et al., 2016; Schaafsma et al., 2016, 2015). However, there has been limited research into the presence and fate of neonicotinoids in groundwater. This is, in part, because early studies about the environmental fate of neonicotinoids found a limited potential for groundwater contamination (Miles Inc., 1993 as reported in Bacey, 2000). However, recent research cites a high likelihood of leaching to the saturated zone based on physical properties and observed behavior in soil and surface water (Anderson et al., 2015; Bacey, 2000; Fossen, 2006; Goulson, 2013; Gupta et al., 2002; Hladik et al., 2014; Kurwadkar et al., 2013; PMRA, 2016a).

Many studies into the presence of neonicotinoids in groundwater omit pertinent information such as surface data (soil type, land use, land-rate application), spatial/temporal contaminant input patterns, along with aquifer and well characteristics. In addition to this, any research about groundwater contamination by neonicotinoids, with the exception of imidacloprid, is limited. Typically, research has summarized the findings from monitoring programs and has not proposed theories for the transport mechanisms of neonicotinoids to groundwater (Department of Environmental Conservation, 2014; Giroux, 2003; Giroux and Sarrasin, 2011; Huseth and Groves, 2014).

\subsection{Scope and Specific Objectives}

Given the sparse and inconsistent nature of research about neonicotinoids in groundwater, there is justification for a more focused study into the presence and fate of these popular insecticides in different aquifers. The purpose of this research is to quantify the fate and presence of neonicotinoids in two distinct Ontario aquifers: the sandy, unconfined aquifer in Norfolk County and the fractured, crystalline bedrock aquifer of Lanark County. This entails a seasonal groundwater sampling regime and subsequent mathematical modelling to determine the environmental parameters that influence the movement of neonicotinoids to groundwater.

This research involved five sampling rounds at both research sites in 2016 and 2017; sampling occurred in April 2016, July 2016, August 2016, November 2016, and April 2017. The April sampling occurred during the spring freshet, the July and August sampling took place between seed sowing and crop harvesting, while the November sampling occurred during corn and soybean crop harvest. Additionally, soil sampling occurred in July 2016 to link surficial neonicotinoid concentrations to those found in groundwater. 
Between 18 and 26 monitoring intervals were sampled at each site during every sampling round (Appendix A - Well Data). These wells were chosen due to past history of past history of vulnerability to surface-applied contaminants, surrounding land use, variations in depth, and well accessibility. For each sample that was taken, a calibrated YSI 556 handheld instrument measured temperature, dissolved oxygen, electrical conductivity, and oxidation-reduction potential (ORP). Nitrate readings were taken on site using a Satlantic SUNA V2 (Satlantic, 2017) and water levels were also monitored at several wells using barometrically-compensated pressure transducers (Solinst Canada Ltd., 2015). Precipitation levels were monitored using rain gauges and local Environment Canada weather stations (Environment and Climate Change Canada, 2017; Hoskin Scientific, 2017).

All samples were analyzed at the University of Guelph Ridgetown campus for the neonicotinoids acetamiprid, clothianidin, dinotefuran, imidacloprid, thiacloprid, and thiamethoxam. Additionally, samples were analyzed for atrazine, azoxystrobin, cyantraniliprole, mefenoxam, and Metolachlor.

A field survey was also conducted using crop data for the years 2015 and 2016 (Agriculture and Agri-Food Canada, 2017). This was coupled with a February 2017 farmer survey in order to estimate the quantity of land-applied neonicotinoids (Appendix D - Farmer Survey Questionnaire).

Numerical and analytical modelling was conducted at LP-MW-02 in Norfolk County and TW17 in Lanark County because they tested positive for clothianidin and thiamethoxam, respectively, at various points throughout the sampling regime. The intention of these modeling exercises was to determine what factors led to the different pattern of neonicotinoid release to these wells. The numerical model Hydrus 1D (Šimůnek et al., 2013) was used to simulate flow and transport through the vadose zone at LP-MW-02, while the analytical Ogata-Banks solution (Ogata and Banks, 1961; Van Genuchten, 1981) was used to simulate transport through the saturated subsurface. At TW17, Hydrus 1D was used to simulate flow through the overburden; the analytical solution for one-dimensional advection with matrix diffusion was used to analyze flow through a fracture (Sudicky, 1988; Sudicky and Frind, 1982; Tang et al., 1981).

\subsection{Thesis Outline}

This section is the first of the five chapters within this thesis. Chapter two is a literature review that has been submitted for publication to the Water Quality Research Journal of Canada. That chapter reviews research into the presence of neonicotinoids in soil, soil dust, leachate, and surface water before providing an encompassing overview of research into neonicotinoids in 
groundwater. An emphasis is placed on studies that have been conducted within Canada. The third chapter details the site history (site description, regional geology and climate, and past research) of the Long Point Monitoring Wells in Norfolk County and the Tay River Watershed Wells in Lanark County. The fourth chapter reviews the objectives and outcomes of this project. It has been written as a manuscript and will be submitted to the Journal of Contaminant Hydrology. Chapter five provides conclusions and recommendations for future research. 


\subsection{References}

Agriculture and Agri-Food Canada, 2017. AAFC Crop Type Feature Catalog.

Anderson, Dubetz, C., Palace, V.P., 2015. Neonicotinoids in the Canadian aquatic environment: A literature review on current use products with a focus on fate, exposure, and biological effects. Sci. Total Environ. doi:10.1016/j.scitotenv.2014.09.090

Bacey, J., 2000. Environmental Fate of Imidacloprid. Sacramento.

Bonmatin, J.M., Giorio, C., Girolami, V., Goulson, D., Kreutzweiser, D.P., Krupke, C., Liess, M., Long, E., Marzaro, M., Mitchell, E.A., Noome, D.A., Simon-Delso, N., Tapparo, A., 2015.

Environmental fate and exposure; neonicotinoids and fipronil. Environ. Sci. Pollut. Res. 22, 3567. doi:10.1007/s11356-014-3332-7

Canadian Council of Ministers of the Environment, 2007. Canadian Water Quality Guidelines for the Protection of Aquatic Life - Imidacloprid. Can. Environ. Qual. Guidel.

Department of Environmental Conservation, 2014. Long Island Pesticide Pollution Prevention Strategy.

Environment and Climate Change Canada, 2017. Historical Data [WWW Document]. URL http://climate.weather.gc.ca/historical_data/search_historic_data_e.html (accessed 6.1.17).

European Commission, 2013. Bee Health: EU-wide restrictions on Pesticide use to enter into force on 1 December, Europa Press Release Database. Brussels.

Fossen, M., 2006. Environmental Fate of Imidacloprid. Regulation 1-16.

Girolami, V., Mazzon, L., Squartini, a, Mori, N., Marzaro, M., Di Bernardo, a, Greatti, M., Giorio, C., Tapparo, a, 2009. Translocation of neonicotinoid insecticides from coated seeds to seedling guttation drops: a novel way of intoxication for bees. J. Econ. Entomol. 1808-1815. doi:10.1603/029.102.0511

Giroux, I., 2003. Contamination de l'eau souterraine par les pesticides et les nitrates dans les régions en culture de pommes de terre, Campagnes d'Echantillonage.

Giroux, I., Sarrasin, B., 2011. Pesticides et nitrates dans l'eau souterraine près de cultures de pommes de terre - Échantillonnage dans quelques régions du Québec en 2008 et 2009.

Goulson, D., 2014. Pesticides linked to bird declines. Nature 511, 295-296. doi:10.1038/nature13642 
Goulson, D., 2013. An overview of the environmental risks posed by neonicotinoid insecticides. J. Appl. Ecol. 50, 977-987. doi:10.1111/1365-2664.12111

Government of Ontario, 2009. Ontario Pesticide Act. Canada.

Gupta, S., Gajbhiye, V.T., Agnihotri, N.P.K., 2002. Leaching behaviour of imidacloprid formulations in soil, Bull. Environ. Contam. Toxicol. 68, 502-508. doi:10.1007/s00128-0010283-8

Hladik, M., Kolpin, D.W., Kuivila, K.M., 2014. Widespread occurrence of neonicotinoid insecticides in streams in a high corn and soybean producing region, USA. Environ. Pollut. 193, 189-196. doi:10.1016/j.envpol.2014.06.033

Hoskin Scientific, 2017. HOBO Rain Gauge Data Logger [WWW Document]. URL https://shoponset.hoskin.ca/products/hobo-rain-gauge-data-logger (accessed 6.29.17).

Huseth, A.S., Groves, R.L., 2014. Environmental fate of soil applied neonicotinoid insecticides in an irrigated potato agroecosystem. PLoS One 9. doi:10.1371/journal.pone.0097081

Kurwadkar, S., Dewinne, D., Wheat, R., McGahan, D.G., Mitchell, F.L., 2013. Time dependent sorption behavior of dinotefuran, imidacloprid and thiamethoxam. J. Environ. Sci. Health. B. 48, 237-42. doi:10.1080/03601234.2013.742412

Kurwadkar, S., Evans, A., 2016. Neonicotinoids: Systemic Insecticides and Systematic Failure. Bull. Environ. Contam. Toxicol. 97, 745-748. doi:10.1007/s00128-016-1968-3

Limay-Rios, V., Forero, L.G., Xue, Y., Smith, J., Baute, T., Schaafsma, A., 2016. Neonicotinoid insecticide residues in soil dust and associated parent soil in fields with a history of seed treatment use on crops in southwestern Ontario. Environ. Toxicol. Chem. 35, 303-310. doi:10.1002/etc.3257

Maienfisch, P., Angst, M., Brandl, F., Fischer, W., Hofer, D., Kayser, H., Kobel, W., Rindlisbacher, A., Senn, R., Steinemann, A., Widmer, H., 2001. Chemistry and biology of thiamethoxam: A second generation neonicotinoid. Pest Manag. Sci. 57, 906-913. doi:10.1002/ps.365

Matsuda, K., Buckingham, S.D., Kleier, D., Rauh, J.J., Grauso, M., Sattelle, D.B., 2001. Neonicotinoids: Insecticides acting on insect nicotinic acetylcholine receptors. Trends Pharmacol. Sci. 22, 573-580. doi:10.1016/S0165-6147(00)01820-4 
Miranda, G.R.B., Raetano, C.G., Silva, E., Daam, M. a., Cerejeira, M.J., 2011. Environmental Fate of Neonicotinoids and Classification of Their Potential Risks to Hypogean, Epygean, and Surface Water Ecosystems in Brazil. Hum. Ecol. Risk Assess. An Int. J. 17, 981-995. doi:10.1080/10807039.2011.588159

Morrissey, C.A., Mineau, P., Devries, J.H., Sanchez-Bayo, F., Liess, M., Cavallaro, M.C., Liber, K., 2015. Neonicotinoid contamination of global surface waters and associated risk to aquatic invertebrates: A review. Environ. Int. doi:10.1016/j.envint.2014.10.024

Ogata, A., Banks, R.B., 1961. A Solution of the Differential Equation of Longitudinal Dispersion in Porous Media, Professional Paper 411-A. Washington, D.C.

PMRA, 2016. Imidacloprid - Proposed Re-Evaluation Decision. Ottawa.

Satlantic, 2017. SUNA [WWW Document]. URL http://satlantic.com/suna Savard, (accessed 6.29.17).

Schaafsma, A., Limay-Rios, V., Baute, T., Smith, J., Xue, Y., 2015. Neonicotinoid insecticide residues in surface water and soil associated with commercial maize (corn) fields in Southwestern Ontario. PLoS One 10, 1-21. doi:10.1371/journal.pone.0118139

Schaafsma, A., Limay-Rios, V., Xue, Y., Smith, J., Baute, T., 2016. Field-scale examination of neonicotinoid insecticide persistence in soil as a result of seed treatment use in commercial maize (corn) fields in southwestern Ontario. Environ. Toxicol. Chem. 35, 295-302. doi:10.1002/etc.3231

Sheets, L.P., 2010. Imidacloprid: A Neonicotinoid Insecticide. Hayes' Handb. Pestic. Toxicol. 2055-2064. doi:10.1016/B978-0-12-374367-1.00095-1

Šimůnek, J., Sejna, M., van Genuchten, M.T., 2013. Code for Simulating the One-Dimensional Movement of Water, Heat, and Multiple Solutes in Variabe Saturated Porous Media.

Solinst Canada Ltd., 2015. Levelogger Series Quick Start Guide. Georgetown, Ontario.

Sudicky, E.A., 1988. CRAFLUSH, Programmer's Guide.

Sudicky, E.A., Frind, E.O., 1982. Contaminant transport in fractured porous media: Analytical solutions for a system of parallel fractures. Water Resour. Res. 18, 1634-1642.

Tang, D.H., Frind, E.O., Sudicky, E.A., 1981. Contaminant transport in fractured porous media: Analytical solution for a single fracture. Water Resour. Res. 17, 555-564. 
Van Genuchten, M.T., 1981. Analytical solutions for chemical transport with simultaneous adsorption, zero-order production and first-order decay. J. Hydrol. 49, 213-233.

doi:10.1016/0022-1694(81)90214-6

Woodcock, B.A., Bullock, J.M., Shore, R.F., Heard, M.S., Pereira, M.G., Redhead, J., Ridding,

L., Dean, H., Sleep, D., Henrys, P., Peyton, J., Hulmes, S., Hulmes, L., Sárospataki, M., Saure,

C., Edwards, M., Genersch, E., Knäbe, S., Pywell, R.F., 2017. Country-specific effects of neonicotinoid pesticides on honey bees and wild bees. Science (80-. ). 356, 1393-1395. doi:10.1126/science.aaa1190 


\section{Literature Review}

\subsection{Abstract}

Neonicotinoids are a group of insecticides that were developed and introduced to commercial use in the 1990s and early 2000s. These insecticides rapidly became popular and widespread in agriculture due to their ease of use and the perception that they are environmentally friendly due to their low-application rates. Despite the widespread application of these insecticides, knowledge surrounding their fate in the environment is not comprehensive. To date, field studies have largely focused on detecting neonicotinoids in soil, soil dust and surface water bodies; studies that monitor and analyze the presence of neonicotinoids in groundwater are far less robust. This review examines the current state of knowledge about the presence and fate of neonicotinoids in soil, surface water and groundwater. A particular focus is placed on research that is either based in the Canadian environment or that examines the presence of neonicotinoids in groundwater. Findings indicate substantial knowledge gaps regarding the fate of neonicotinoids in groundwater. Further research about the presence of neonicotinoids in groundwater should be conducted in agricultural-intensive regions. 


\subsection{Introduction}

Neonicotinoids are a group of insecticides that are commonly used in agriculture. Initially applied as a spray or seed treatment, these insecticides reduce pest infestations and the prolificacy of plant disease at very low application rates (Kurwadkar and Evans, 2016). When applied as a seed treatment, neonicotinoids are taken in by the roots of plants and transported through the plant where they can act on feeding insects (Canadian Council of Ministers of the Environment, 2007). All neonicotinoids act as an agonist at nicotinoid acetylcholine receptors (nAChRs) within the central nervous system of target insects; once ingested by the insect, neonicotinoids cause paralysis and/or death (Canadian Council of Ministers of the Environment, 2007; Goulson, 2013; Matsuda et al., 2001).

The first neonicotinoid, imidacloprid, was introduced in 1991 by Bayer Crop Science Inc. (Maienfisch et al., 2001). Imidacloprid was followed by other first generation neonicotinoids nitenpyram, thiacloprid and acetamiprid in the mid-1990s (Maienfisch et al., 2001). Second generation neonicotinoids include clothianidin and thiamethoxam; the third generation is dinotefuran. These generations differ from each other in chemical composition - the first generation uses a chloropyridinyl moiety; the second generation uses a chlorothiazolyl group; while the third generation uses acetylcholine instead of nicotine (Sheets, 2010).

When neonicotinoids entered the market, they were seen as an environmentally-friendly alternative to older treatments since they do not affect non-target organisms such as mammals (Schaafsma et al., 2015). This success, in conjunction with the perception that neonicotinoids are environmentally-friendly, led to a shift from their use in response to pest infestation to their application prior to any sign of pest damage. In Ontario, clothianidin and thiamethoxam are the most widespread neonicotinoids; they are typically used as a seed treatment on corn, soybeans, cereals, dry edible beans and canola/mustard (Schaafsma et al., 2016) 
Table 2.1: Application rates of neonicotinoids in Ontario (Ontario Ministry of Agriculture and Food and Rural Affairs, 2016). Unless otherwise stated, neonicotinoids are applied as a seed dressing. All neonicotinoids listed in this table are registered by the Government of Canada and classified by the Ontario Ministry of Environment and Climate Change. This means the neonicotinoids have been authorized for use in Ontario after the evaluation of scientific data to ensure the product is effective and has acceptable environmental risks.

\begin{tabular}{|c|c|c|c|}
\hline Neonicotinoid & Crop Type & Trade Name & Application Rate \\
\hline Acetamiprid & $\begin{array}{l}\text { Not recommended } \\
\text { for use }\end{array}$ & $\mathrm{N} / \mathrm{A}$ & $N / A$ \\
\hline \multirow{9}{*}{ Clothianidin } & \multirow{4}{*}{ Corn } & Poncho 1250 & $166.7 \mathrm{~mL} / 80,000$ kernels \\
\hline & & Poncho 250 & $33.3 \mathrm{~mL} / 80,000$ kernels \\
\hline & & \multirow{2}{*}{ Nipsit Inside 600} & $166.7 \mathrm{~mL} / 80,000$ kernels \\
\hline & & & $33.3 \mathrm{~mL} / 80,000$ kernels \\
\hline & \multirow{3}{*}{ Cereals } & \multirow{2}{*}{ Nipsit Inside 600} & 33-100 mL / $100 \mathrm{~kg}$ seed \\
\hline & & & $50 \mathrm{~mL} / 100 \mathrm{~kg}$ seed \\
\hline & & $\begin{array}{l}\text { Nipsit SUITE } \\
\text { Cereals OF }\end{array}$ & $326 \mathrm{~mL} / 100 \mathrm{~kg}$ seed \\
\hline & \multirow[b]{2}{*}{$\begin{array}{l}\text { Canola and } \\
\text { Mustard }\end{array}$} & Prosper FL & $1.25 \mathrm{~L} / 100 \mathrm{~kg}$ seed \\
\hline & & $\begin{array}{l}\text { Nipsit Suite Canola } \\
\text { Seed Protection }\end{array}$ & $1.43 \mathrm{~L} / 100 \mathrm{~kg}$ seed \\
\hline Dinotefuran & $\begin{array}{l}\text { Not recommended } \\
\text { for use }\end{array}$ & $N / A$ & $\mathrm{~N} / \mathrm{A}$ \\
\hline \multirow{10}{*}{ Imidacloprid } & \multirow{3}{*}{ Corn } & \multirow{2}{*}{ Gaucho $480 \mathrm{FL}$} & $27 \mathrm{~mL} / 80,000$ kernels \\
\hline & & & $100 \mathrm{~mL} / 80,000$ kernels \\
\hline & & Sombrero 600 FS & $21.3 \mathrm{~mL} / 80,000$ kernels \\
\hline & \multirow{2}{*}{ Soybean } & Stress Shield 600 & 104-208 mL / $100 \mathrm{~kg}$ seed \\
\hline & & Concept & 325-650 mL / ha* \\
\hline & \multirow{3}{*}{ Cereals } & Alias 240 SC & $42-125 \mathrm{~mL} / 100 \mathrm{~kg}$ seed \\
\hline & & \multirow{2}{*}{ Stress Shield 600} & $17-50 \mathrm{~mL} / 100 \mathrm{~kg}$ seed \\
\hline & & & $104 \mathrm{~mL} / 100 \mathrm{~kg}$ seed \\
\hline & \multirow{2}{*}{$\begin{array}{l}\text { Canola and } \\
\text { Mustard }\end{array}$} & Gaucho $480 \mathrm{FL}$ & $\begin{array}{l}820-1640 \mathrm{~mL} / 100 \mathrm{~kg} \\
\text { seed }\end{array}$ \\
\hline & & Gaucho CS FL & $1.4 \mathrm{~L} \mathrm{/} 100 \mathrm{~kg}$ seed \\
\hline Nitenpyram & $\begin{array}{l}\text { Not recommended } \\
\text { for use }\end{array}$ & $\mathrm{N} / \mathrm{A}$ & $\mathrm{N} / \mathrm{A}$ \\
\hline Thiacloprid & $\begin{array}{l}\text { Not recommended } \\
\text { for use }\end{array}$ & $\mathrm{N} / \mathrm{A}$ & $\mathrm{N} / \mathrm{A}$ \\
\hline \multirow{8}{*}{ Thiamethoxam } & \multirow[b]{2}{*}{ Corn } & \multirow[b]{2}{*}{ Cruiser 5 FS } & $166.7 \mathrm{~mL} / 80,000$ kernels \\
\hline & & & $\begin{array}{c}\text { 16.7-33.3 } \mathrm{mL} / 80,000 \\
\text { kernels }\end{array}$ \\
\hline & \multirow{3}{*}{ Soybeans } & Cruiser 5 FS & $50-83 \mathrm{~mL} / 100 \mathrm{~kg}$ seed \\
\hline & & $\begin{array}{c}\text { Cruiser Maxx } \\
\text { Beans }\end{array}$ & $195 \mathrm{~mL} / 100 \mathrm{~kg}$ seed \\
\hline & & Endigo & $180 \mathrm{~mL} / \mathrm{ha}^{*}$ \\
\hline & Cereals & Cruiser 5 FS & $33-50 \mathrm{~mL} / 100 \mathrm{~kg}$ seed \\
\hline & \multirow{2}{*}{ Dry Edible Beans } & \multirow{2}{*}{ Cruiser 5 FS } & $50-80 \mathrm{~mL} / 100 \mathrm{~kg}$ seed \\
\hline & & & $86-183 \mathrm{~mL} / 100 \mathrm{~kg}$ seed \\
\hline
\end{tabular}




\begin{tabular}{|c|c|c|c|} 
& \multirow{2}{*}{} & $\begin{array}{c}\text { Cruiser Maxx } \\
\text { Beans }\end{array}$ & $195 \mathrm{~mL} / 100 \mathrm{~kg}$ seed \\
\cline { 2 - 3 } & Endigo & $180 \mathrm{~mL} / \mathrm{ha}^{*}$ \\
\cline { 2 - 3 } & $\begin{array}{c}\text { Canola and } \\
\text { Mustard }\end{array}$ & Helix Vibrance & $1.5 \mathrm{~L} / 100 \mathrm{~kg}$ seed \\
\hline
\end{tabular}

${ }^{*}$ Applied as a foliar treatment

In 2012, neonicotinoids were used more than any other type of insecticide with a global market value of approximately $\$ 2.6$ billion (Goulson, 2013). In 2016, imidacloprid was the most widely used insecticide in the world (Kurwadkar and Evans, 2016). As of 2013 in Ontario, Canada, neonicotinoid-treated seeds were used on $99 \%$ of corn, $65 \%$ of soybeans, $25-33 \%$ of cereals, $95 \%$ of dry beans and $100 \%$ of canola (Stewart et al., 2013). This widespread use goes against the principles of integrated pest management (Goulson, 2013).

In December 2013, the European Union (EU) imposed a partial restriction on neonicotinoids usage due to concerns about their impact on pollinators and other beneficial insects. This decision has been criticized on the grounds that the benefits of neonicotinoid use outweigh any detriment they might cause (Godfray et al., 2014). On July 1, 2015, rules for the sale and use of neonicotinoid-treated seeds were introduced in Ontario. This legislation stipulates certain actions with the target of an $80 \%$ reduction (compared to 2015 levels) of the number of acres planted with neonicotinoid-treated maize and soybean crops by 2017 (Government of Ontario, 2009). Health Canada's Pest Management Regulatory Agency (PMRA) is also proposing to phase-out all agricultural and many other outdoor uses of imidacloprid over three to five years (PMRA, 2016a).

In certain hydrogeological settings, groundwater is sensitive to contamination from land-applied substances in agricultural areas (Kohn et al., 2015; Levison and Novakowski, 2012; Lockhart et al., 2013; Neshat et al., 2014; Paradis et al., 2016). Since neonicotinoids have been used extensively in agriculture, it is important to quantify their movement through the environment. To date, research has typically focused on the presence and fate of neonicotinoids in dust particles, soil and surface water. Research about the presence of neonicotinoids in groundwater is much less common.

The presence of neonicotinoids in groundwater should be quantified to assess whether mean or peak concentrations pose a risk to non-target species. In rural regions where the agricultural use of neonicotinoids is ubiquitous, residents typically rely on private wells for their potable water supply - this presents a potential risk to human health. Groundwater can also directly and indirectly (through discharge) come into contact with non-target species. 
The purpose of this paper is to review literature and outline knowledge gaps about the presence of neonicotinoids in the environment - this includes studies about soil and surface water but focuses on groundwater media. Throughout this paper, groundwater is defined as the saturated subsurface.

This paper provides a comprehensive review of past studies concerning neonicotinoids in groundwater. While research about neonicotinoids in international environments such as Vietnam, Brazil, the United States and Europe are noted for context and comparison, a particular emphasis is placed on research conducted in and throughout Canada. A conceptual diagram that depicts the current state of knowledge about that fate of neonicotinoids in groundwater and the environment is developed.

\subsection{Physical Properties}

The persistence of neonicotinoids varies with field conditions such as environmental $\mathrm{pH}$, the presence of a microbial community, exposure to sunlight, temperature, and formulation of the insecticide (Bonmatin et al., 2015). Their physical properties are presented in Table 2.2.

In the absence of metal ions and minerals, imidacloprid and thiamethoxam are hydrolytically stable at a pH between 4 and 8, yet decline rapidly in alkaline media (Engan, 2016). Imidacloprid, clothianidin, dinotefuran and thiamethoxam degrade rapidly through photolysis in water (Goulson, 2013). It is also important to note that neonicotinoids are non-volatile and thiamethoxam metabolizes into clothianidin under agricultural soil conditions (Anderson et al., 2015; Food and Agriculture Organization of the United Nations and World Health Organization, 2011; Schaafsma et al., 2015). Thiamethoxam is not converted to clothianidin under aqueous field conditions (Maienfisch, 2006).

The Groundwater Ubiquity Score (GUS) is a calculation of the potential for a substance to contaminate groundwater based on $\mathrm{K}_{\mathrm{oc}}$ and half-life (DT50) values (Bonmatin et al., 2015). It is calculated as follows:

$$
G U S=\log _{10}(D T 50) x\left(4-\log _{10}\left(K_{O C}\right)\right)
$$

Hydrolytic properties indicate a tendency for water solubility among neonicotinoids, ranging from moderate (thiacloprid at $184 \mathrm{mg} / \mathrm{L}$ ) to high (dinotefuran at $39,830 \mathrm{mg} / \mathrm{L}$ ) ( Table 2.2). All neonicotinoids have an octanol-water partition coefficient $\left(\log \left(K_{o w}\right)\right)$ value below or near 1 - this indicates a preference for solubility in water versus octanol (fat) in non-target species. Thus, $\log \left(\mathrm{K}_{\mathrm{ow}}\right)$ values indicate a low potential for all neonicotinoids to accumulate in the 
food chain. The soil adsorption coefficient $\left(\log \left(K_{o c}\right)\right)$ is a measure of tendency to sorb to organic carbon in soil. $\log \left(\mathrm{K}_{\mathrm{OC}}\right)$ values for neonicotinoids are less than 2.5 - this indicates a low organic carbon adsorption tendency and suggests a potential to leach. The GUS displays a potential for leaching to groundwater for most neonicotinoids; the aqueous dissipation and water hydrolysis half-lives indicate that neonicotinoids can persist in groundwater for weeks before breaking down, while the aqueous photolysis half-life means that neonicotinoids are unlikely to be found in surface water that is exposed to sunlight. Considering these physical properties, neonicotinoids are likely to be found in groundwater for a short period of time (on the order of weeks).

Table 2.2: Physical properties of neonicotinoids (Bonmatin et al., 2015; Hladik et al., 2014; Morrissey et al., 2015).

\begin{tabular}{|c|c|c|c|c|c|c|c|}
\hline Neonicotinoid & $\begin{array}{l}\log \\
K_{O C}\end{array}$ & $\begin{array}{l}\text { Log } \\
\text { Kow }\end{array}$ & $\begin{array}{c}\text { Groundwater } \\
\text { Ubiquity } \\
\text { Score (GUS) }\end{array}$ & $\begin{array}{c}\text { Solubility } \\
\text { in water at } \\
20^{\circ} \mathrm{C} \text { at pH } \\
7(\mathrm{mg} / \mathrm{L})\end{array}$ & $\begin{array}{l}\text { Aqueous } \\
\text { Dissipation } \\
\text { Half-Life } \\
\text { (days) }\end{array}$ & $\begin{array}{c}\text { Aqueous } \\
\text { Photolysis } \\
\text { DT50 at } \\
\text { pH } 7 \text { (days) }\end{array}$ & $\begin{array}{l}\text { Water } \\
\text { Hydrolysis } \\
\text { Half-Life } \\
\text { (days) }\end{array}$ \\
\hline Acetamiprid & 2.3 & 0.80 & $\begin{array}{c}0.94 \\
\text { (very low) }\end{array}$ & $\begin{array}{l}2950 \\
\text { (high) }\end{array}$ & 4.7 & 34 (stable) & $\begin{array}{c}420 \\
\text { (stable) }\end{array}$ \\
\hline Clothianidin & 2.1 & 0.91 & $\begin{array}{c}4.91 \\
\text { (very high) }\end{array}$ & $\begin{array}{c}340 \\
\text { (moderate) }\end{array}$ & 40.3 & 0.1 (fast) & $\begin{array}{c}14.4 \\
\text { (stable) }\end{array}$ \\
\hline Dinotefuran & 1.4 & -0.55 & $\begin{array}{c}4.95 \\
\text { (very high) }\end{array}$ & $\begin{array}{c}39,830 \\
\text { (high) }\end{array}$ & $\mathrm{N} / \mathrm{A}$ & 0.2 (fast) & Stable \\
\hline Imidacloprid & $\begin{array}{l}2.1 \\
\text { to } \\
2.5\end{array}$ & 0.57 & $\begin{array}{l}3.76 \\
\text { (high) }\end{array}$ & 610 (high) & 30 & 0.2 (fast) & $\begin{array}{l}\text { > } 1 \text { year } \\
\text { (stable) }\end{array}$ \\
\hline Nitenpyram & 1.78 & -0.66 & $\begin{array}{c}2.01 \\
\text { (moderate) }\end{array}$ & 590,000 & $\mathrm{~N} / \mathrm{A}$ & $\mathrm{N} / \mathrm{A}$ & $\begin{array}{c}2.9 \\
\text { (stable) }\end{array}$ \\
\hline Thiacloprid & $\mathrm{N} / \mathrm{A}$ & 1.26 & $\begin{array}{l}1.44 \\
\text { (low) }\end{array}$ & $\begin{array}{c}184 \\
\text { (moderate) }\end{array}$ & 8.5 & Stable & Stable \\
\hline Thiamethoxam & 1.8 & -0.13 & $\begin{array}{c}3.82 \\
\text { (high) }\end{array}$ & $\begin{array}{l}4100 \\
\text { (high) }\end{array}$ & 30.6 & $\begin{array}{c}2.7 \\
\text { (moderately } \\
\text { fast) }\end{array}$ & $\begin{array}{c}11.5 \\
\text { (stable) }\end{array}$ \\
\hline
\end{tabular}

\subsection{Regulation and Water Quality Guidelines}

Published ecological aquatic reference values for various jurisdictions are listed in Table 2.3. These values are either chronic or acute levels of aquatic contamination that can be considered harmful to non-target species. Reference values vary around the world with $0.36 \mu \mathrm{g} / \mathrm{L}$ and $0.041 \mu \mathrm{g} / \mathrm{L}$ recommended as the respective average and maximum acceptable levels of imidacloprid in Canadian freshwaters. Imidacloprid is the only neonicotinoid with a reference value in Canada. 
Table 2.3: Published ecological quality reference values (average and maximum) for neonicotinoids in freshwater environments. Average (acute) and maximum (peak) values are compared. This table was adapted from Morrissey et al. (2015).

\begin{tabular}{|c|c|c|c|}
\hline Location & Neonicotinoid & $\begin{array}{l}\text { Reference Value } \\
(\mu \mathrm{g} / \mathrm{L})\end{array}$ & Source \\
\hline Canada & Imidacloprid & $\begin{array}{c}0.36 \text { (average) } \\
0.041 \text { (maximum) }\end{array}$ & (PMRA, 2016a) \\
\hline United States & Imidacloprid & $\begin{array}{c}1.05 \text { (average) } \\
35.0 \text { (maximum) }\end{array}$ & EPA (2014) \\
\hline $\begin{array}{c}\text { Europe } \\
\text { Netherlands }\end{array}$ & $\begin{array}{l}\text { Imidacloprid } \\
\text { Imidacloprid }\end{array}$ & $\begin{array}{l}0.2 \text { (maximum) } \\
0.067 \text { (average) }\end{array}$ & $\begin{array}{l}\text { EFSA (2008) } \\
\text { RIVM (2008) }\end{array}$ \\
\hline Sweden & Imidacloprid & $\begin{array}{c}\text { Acetamiprid: } 0.1 \\
\text { Imidacloprid: } 0.013\end{array}$ & Kreuger et al. (2010) \\
\hline $\begin{array}{c}\text { Independent United } \\
\text { States Study } \\
\text { Recommendation }\end{array}$ & Imidacloprid & 0.0086 (average) & $\begin{array}{l}\text { Mineau \& Palmer } \\
(2013)\end{array}$ \\
\hline $\begin{array}{l}\text { Independent Canadian } \\
\text { Study Recommendation }\end{array}$ & All neonicotinoids & $\begin{array}{l}0.035 \text { (average) } \\
0.2 \text { (maximum) }\end{array}$ & Morrissey et al. (2015) \\
\hline
\end{tabular}

Regulation of neonicotinoids varies across the globe. The European Union imposed a temporary moratorium on all neonicotinoids in 2013 (Kurwadkar and Evans, 2016). This ban was put into place due to concerns about the effect of neonicotinoids on pollinator populations. The EU moratorium has been extended beyond the two year timeline and is still in place as of publication date.

The United States Environmental Protection Agency has not banned any neonicotinoids in agriculture (Kurwadkar and Evans, 2016). Regionally, the only state to place restrictions in neonicotinoid use is Minnesota; they permit the use of neonicotinoid insecticides only after a farmer demonstrates a need for their use (Gunderson and Bunbar, 2016). In January of 2017, the US EPA released pollinator and risk assessments for imidacloprid, clothianidin and thiamethoxam. These files state that some neonicotinoids can pose a risk to pollinator populations and aquatic species; regulatory recommendations will be released in 2018 (Unglesbee, 2017).

In Ontario, legislation stipulates certain actions with the goal of reducing the use of all registered neonicotinoids (imidacloprid, clothianidin and thiamethoxam) by $80 \%$ in 2017 compared to 2015 levels (Arkins, 2015). If $50 \%$ or more of a farmer's crop is treated with neonicotinoids, the farmer must complete a report that shows they have an insect problem. In addition to this, Ontario has banned neonicotinoids for use as a cosmetic pesticide in urban centers (Government of Ontario, 2009). Federally, in late 2016 the Canadian PMRA proposed a full phase out of imidacloprid within three to five years (PMRA, 2016a). This proposed ban was based on the impact of imidacloprid 
on aquatic species. Similar reports on clothianidin and thiamethoxam are forthcoming (PMRA, 2016b).

\subsection{Application Rates}

In developed countries, neonicotinoids are typically applied as a seed dressing in order to reduce human exposure to the insecticide (Goulson, 2013). A seed dressing involves applying the insecticide to the seed prior to purchasing and field application (Taylor and Harman, 1990). As of 2015 in Ontario, these seed treatments were typically applied to more than 99\% of maize (corn), $60 \%$ to $80 \%$ of soybean, $95 \%$ of dry bean, $25 \%$ of winter wheat and $100 \%$ of canola (Schaafsma et al., 2016).

Application rates of neonicotinoids are not monitored in Canada. However, sales of insecticide active ingredients indicate a rapid rise in the use of neonicotinoids between 2008 and 2011 (Table 2.4). In 2008, there were no neonicotinoids among the 10 most popular insecticides sold in Canada (Health Canada, 2008). By 2011, both thiamethoxam and clothianidin were among the top 10 (Health Canada, 2011). However in 2014, only clothianidin was in that group (Health Canada, 2014). Dinotefuran and nitenpyram are not registered for use in Canada.

Table 2.4: Active Ingredient of neonicotinoids sold in Canada in 2008, 2011 and 2014.

\begin{tabular}{cccc}
\hline Neonicotinoid & $\begin{array}{c}\text { Active Ingredient Sold } \\
\text { in } 2008^{\mathrm{a}}(\mathrm{kg})\end{array}$ & $\begin{array}{c}\text { Active Ingredient Sold } \\
\text { in } 2011^{\mathrm{b}}(\mathrm{kg})\end{array}$ & $\begin{array}{c}\text { Active Ingredient Sold } \\
\text { in } 2014^{\mathrm{c}}(\mathrm{kg})\end{array}$ \\
\hline $\begin{array}{c}\text { Acetamiprid } \\
\text { Clothianidin }\end{array}$ & $<50,000$ & $<50,000$ & $<50,000$ \\
Imidacloprid & $<50,000$ & $100,000-500,000$ & $100,000-500,000$ \\
Thiacloprid & $<50,000$ & $50,000-100,000$ & $50,000-100,000$ \\
Thiamethoxam & $50,000-100,000$ & $<50,000$ & $<50,000$ \\
a Health Canada (2008) & ${ }^{\mathrm{b}}$ Health Canada (2011) & ${ }^{\mathrm{c}}$ Health Canada $(2014)$
\end{tabular}

The amount of active ingredient used per seed varies depending on crop and seed type. Past studies that have investigated neonicotinoid application rates in Canada have used several approaches to estimate field application rates.

Schaafsma et al. (2016) reported crop seed treatment application rates in southwestern Ontario based on information provided by local seed dealers (Table 2.5). This study used a cumulative neonicotinoid application rate because thiamethoxam metabolizes into clothianidin while all other neonicotinoids were not common in the southwestern Ontario study area. 
Table 2.5: Active ingredient of neonicotinoids in southwestern Ontario (Schaafsma et al., 2016).

\begin{tabular}{cc}
\hline Crop & $\begin{array}{c}\text { Neonicotinoid Seed Treatment } \\
\text { Application Rate }\end{array}$ \\
\hline Soybean & $0.026 \mathrm{mg}$ a.i./seed \\
Corn & $0.25 \mathrm{mg} \mathrm{a.i./seed}$ \\
Canola & $4 \mathrm{~g}$ a.i./. $/ \mathrm{kg}$ seed \\
Winter Wheat & $0.3 \mathrm{~g}$ a.i./seed \\
\hline a.i. = active ingredient.
\end{tabular}

Stewart et al. (2013) estimated an application rate of neonicotinoids from seed treatments based on a sample product used per crop (Table 2.6). This method is effective when the type of seed treatment is a known constant within the study site.

Table 2.6: Application rate of neonicotinoid seed treatments in Ontario (Stewart et al., 2013).

\begin{tabular}{cccc}
\hline Crop & Product & Active Ingredient & Rate (grams a.i./acre) \\
\hline Corn & Poncho 600FS & Clothianidin & 8.25 \\
Soybeans & Cruiser 350FS & Thiamethoxam & 4.25 \\
Canola & Gaucho 480 & Imidacloprid & $9-17$ \\
Dry Beans & Cruiser 5FS & Thiamethoxam & $6-10$ \\
Wheat & Cruiser 5FS & Thiamethoxam & $12-18$ \\
\hline a.i. = active ingredient & &
\end{tabular}

a.i. = active ingredient

The OMAFRA (2016) crop protection guide provides information about regulations for application rates of neonicotinoids given the insect on the field crop. A summary of these application rates is provided in Table 2.1. Acetamiprid, dinotefuran, nitenpyram and thiacloprid are not registered for use in Ontario.

Anderson et al. (2015) used neonicotinoid sales data (provided by Environment Canada) to estimate national application rates. This approach makes the assumption that all neonicotinoid-treated seeds purchased in a particular year are used in that year.

Main et al. (2014) used an integrated approach to estimate neonicotinoid application rates. This involved a combination of field crop inventory maps (provided by Agri-Food Canada), the percentage of each crop treated with neonicotinoids (obtained from confidential PMRA data), and the recommended pesticide application rates. This approach provides a robust depiction of regional application rates, but is dependent on the error inherent in the field crop inventory maps (85\% accuracy with a spatial resolution of $30 \mathrm{~m}$ ) (OMAFRA, 2016). 


\subsection{Neonicotinoids in the Environment}

\subsubsection{Fate in Soil}

Research about the fate of neonicotinoids in the environment typically focuses on their persistence and accumulation in the soil over time. As a result, the literature about neonicotinoids in soil (both lab and field experiments) is extensive.

The bulk of neonicotinoid active ingredient - typically more than 90\% - enters the soil (Goulson, 2013). However, the half-life of neonicotinoids in soil has been found to vary substantially between studies. Imidacloprid half-life was found to vary from 3 to 4 months to over 1 year in soils within the United States (US EPA, 1993). Clothianidin half-life in soil varies from 148 to 7000 days, while acetamiprid, dinotefuran, thiacloprid and thiamethoxam vary from 31-450 days, 75-82 days, 3.4 to greater than 1000 days, and from 7 to 335 days, respectively, in soil (Decant, 2010; Goulson, 2013).

This variation in soil half-life is dependent on environmental conditions such as soil type, exposure to sunlight, moisture, temperature, $\mathrm{pH}$, and field cropping practice (Anderson et al., 2015; Bonmatin et al., 2015; Canadian Council of Ministers of the Environment, 2007; Schaafsma et al., 2016). Imidacloprid, for example, was found to sorb persistently in soil with low water content, high $\mathrm{pH}$, high organic matter and high mineral clay content. It also desorbs slowly from soil with low temperatures and low pesticide concentrations (Bonmatin et al., 2015; Fossen, 2006; Goulson, 2013). Acetamiprid and thiamethoxam, on the other hand, are immobile under dry soil conditions (Bonmatin et al., 2015). Imidacloprid, dinotefuran and thiamethoxam have demonstrated a limited ability to sorb with sandy-loam soils (Kurwadkar et al., 2013).

Imidacloprid leachate dissipates in a biphasic pattern. This involves an initial rapid phase followed by a slower second phase (Junior et al., 2004). Thiamethoxam and clothianidin have displayed the highest leaching rate during crop harvest (roughly 100 days after planting). Thiamethoxam concentrations in leachate increase during precipitation events (Huseth and Groves, 2014).

Schaafsma et al. (2016) conducted a study about neonicotinoid persistence in agricultural soils in southwestern Ontario between 2013 and 2014. This found that after 3 to 4 years of repeated use, neonicotinoid residues in soil plateau to a mean concentration of $6 \mathrm{ng} / \mathrm{g}$. Persistence of neonicotinoids correlates with soil silt content and negatively correlates with soil sand content. This is consistent with findings by Bacey (2000) which found that imidacloprid was relatively immobile in silty soils. 
Several studies concerning the presence and fate of neonicotinoids in soils cite a potential for leaching into surface water and groundwater (Canadian Council of Ministers of the Environment, 2007; Goulson, 2013; PMRA, 2016a; Schaafsma et al., 2016). Research about the fate of neonicotinoids in surface water is widespread. Several of these studies are summarized in Table

\section{7 .}

Table 2.7: Summary of field studies about neonicotinoids in soil and soil leachate. DF, LOD and, LOQ refer to Detection Frequency, Level of Detection, and Level of Quantitation, respectively. Peak is the maximum concentration that was recorded during each study.

\begin{tabular}{|c|c|c|c|c|c|c|c|c|}
\hline Medium & Neonicotinoid & Location & Soil & $\begin{array}{l}\text { Land Use or } \\
\text { Land-Rate } \\
\text { Application }\end{array}$ & $\begin{array}{l}\text { DF } \\
(\%)\end{array}$ & $\begin{array}{c}\text { LOD } \\
\text { [LOQ] } \\
\text { (ppb) }\end{array}$ & $\begin{array}{l}\text { Peak } \\
\text { (ppb) }\end{array}$ & Reference \\
\hline Soil & Imidacloprid & Netherlands & Clay & $\begin{array}{l}\text { Winter } \\
\text { Wheat }\end{array}$ & 100 & [0.6] & 111 & $\begin{array}{c}\text { Junior et al. } \\
(2004)\end{array}$ \\
\hline Soil & Imidacloprid & $\mathrm{N} / \mathrm{A}$ & Varied & Varied & 92.5 & 0.1 & ס & $\begin{array}{l}\text { Bonmatin et } \\
\text { al. (2005) }\end{array}$ \\
\hline Soil & $\begin{array}{l}\text { Clothianidin + } \\
\text { Thiamethoxam }\end{array}$ & $\begin{array}{l}\text { Southwestern } \\
\text { Ontario }\end{array}$ & Varied & $\begin{array}{l}\text { Maize } \\
\text { (corn) }\end{array}$ & 100 & $\begin{array}{c}0.023 \\
{[0.063]} \\
0.017 \\
{[0.045]} \\
0.023\end{array}$ & 20.3 & $\begin{array}{l}\text { Schaafsma } \\
\text { et al. (2016) }\end{array}$ \\
\hline Soil & $\begin{array}{l}\text { Clothianidin + } \\
\text { Thiamethoxam }\end{array}$ & $\begin{array}{l}\text { Southwestern } \\
\text { Ontario }\end{array}$ & Varied & Varied & 100 & $\begin{array}{c}{[0.063]} \\
0.017 \\
{[0.045]}\end{array}$ & $\begin{array}{l}14.55 \\
\text { (total) }\end{array}$ & $\begin{array}{l}\text { Limay Rios } \\
\text { et al. (2016) }\end{array}$ \\
\hline $\begin{array}{c}\text { Soil } \\
\text { leachate }\end{array}$ & Imidacloprid & $\begin{array}{c}\text { California, } \\
\text { USA }\end{array}$ & $\begin{array}{l}\text { Sandy } \\
\text { loam }\end{array}$ & $N / A$ & $\mathrm{~N} / \mathrm{A}$ & $\mathrm{N} / \mathrm{A}$ & BDL & $\begin{array}{c}\text { Miles Inc. } \\
(1992)\end{array}$ \\
\hline $\begin{array}{c}\text { Soil } \\
\text { leachate }\end{array}$ & Imidacloprid & Netherlands & Clay & $\begin{array}{l}\text { Winter } \\
\text { Wheat }\end{array}$ & 100 & [0.05] & 0.7 & $\begin{array}{c}\text { Junior et al. } \\
(2004)\end{array}$ \\
\hline $\begin{array}{c}\text { Soil } \\
\text { leachate }\end{array}$ & $\begin{array}{l}\text { Clothianidin } \\
\text { Thiamethoxam }\end{array}$ & $\begin{array}{c}\text { Wisconsin, } \\
\text { USA }\end{array}$ & $\begin{array}{l}\text { Loamy } \\
\text { sand }\end{array}$ & Potato farm & $\begin{array}{c}25 \\
100\end{array}$ & 0.2 & $\begin{array}{l}0.225 \\
0.580\end{array}$ & $\begin{array}{c}\text { Huseth and } \\
\text { Groves } \\
\text { (2014) }\end{array}$ \\
\hline
\end{tabular}

\subsubsection{Fate in Surface Water}

The presence of neonicotinoids in surface waters depends on water temperature, $\mathrm{pH}$, exposure to sunlight and the physical state of the applied insecticide (Bonmatin et al., 2015). These insecticides are most frequently detected in surface runoff from agricultural fields (Canadian Council of Ministers of the Environment, 2007). Temporal patterns of neonicotinoid concentrations in stream water can be correlated to rain events during crop planting (Hladik et al., 2014). This indicates that seed treatments are the likely source of surface water contamination from neonicotinoids. It's not clear whether neonicotinoids absorb to water or are carried by soil particles (Limay-Rios et al., 2016). 
Neonicotinoids are either moderately or highly soluble in water at $20^{\circ} \mathrm{C}$ and $\mathrm{pH} 7-$ ranging from $184 \mathrm{mg} / \mathrm{L}$ to $590,000 \mathrm{mg} / \mathrm{L}$ for thiacloprid and nitenpyram, respectively (Morrissey et al., 2015). In surface water, the breakdown of most neonicotinoids is due to aqueous photolysis; acetamiprid and thiacloprid are the only neonicotinoids that are photolytically stable (Bonmatin et al., 2015; Fossen, 2006)

Table 2.2). At an environmentally-relevant $\mathrm{pH}$, hydrolysis is not expected to be a major fate process of imidacloprid in surface water (Canadian Council of Ministers of the Environment, 2007). However, the rate of hydrolysis of imidacloprid in an aqueous environment is expected to increase with temperature (Bonmatin et al., 2015).

Before returning to pre-planting levels, neonicotinoid residues (clothianidin and thiamethoxam) increased in puddles within southwestern Ontario maize fields for 5 to 6 weeks after planting (Schaafsma et al., 2015). These residues did not display a significant fluctuation in puddles surrounding the agricultural fields over the course of a growing season, indicating that these neonicotinoids may not move into offsite surface waters.

However, imidacloprid, has been found to move offsite and contaminate surface waters (Starner and Goh, 2012). According to The Health Canada Pest Management Regulatory Agency (2016), imidacloprid detection in surface water is likely the result of its persistence in soil, potential for mobility and its widespread use. The report calculated that imidacloprid has been detected in 15\% of approximately 11,350 surface water samples in Canada and the United States. Between 2010 and 2014, imidacloprid was found above the level of detection in $68 \%$ of 355 surface water samples. In Ontario, 86\% of 470 surface water samples between 2011 and 2014 found imidacloprid above the level of detection (PMRA, 2016a).

Neonicotinoids can contaminate surface runoff in pulses (Main et al., 2014). The highest concentrations and detection frequencies are typically found during the spring freshet when stagnant neonicotinoids from the previous growing season are flushed into aquatic systems (Main et al., 2014). Precipitation is an important factor in neonicotinoid transport to streams; aquatic acetamiprid concentrations spike with tilling and rain events (Anderson et al., 2013; Hladik and Kolpin, 2015). Subsurface tile drains can also contribute to surface water contamination (Wettstein et al., 2016).

Clothianidin and thiamethoxam detections were positively correlated to agricultural land use, while imidacloprid was positively correlated to urban land use (Chrétien et al., 2017; Hladik and Kolpin, 2015). This relationship between land use and aquatic detection frequency is reinforced by 
studies showing increasing detections imidacloprid in eastern Canadian surface water with increased land-rate application over time (Denning et al., 2004).

Between 2010 and 2012, Giroux (2014) monitored neonicotinoids in streams near agricultural activity. Thiamethoxam was detected most frequently in the potato-intensive regions, while areas with potato, corn and soy agriculture found imidacloprid, thiamethoxam and clothianidin in similar concentrations and at similar frequencies. No temporal patterns were observed.

Struger et al. (2017) correlated land use to the presence of neonicotinoids in 15 ponds across southwestern Ontario between 2012 and 2014. Thiamethoxam was detected at similar frequencies and locations as clothianidin. These two neonicotinoids are synonymous with row crops in Ontario and were frequently found in water bodies near these crops. Imidacloprid and acetamiprid were positively correlated with greenhouses, vegetables, vineyards and orchards. In Canada, thiacloprid is registered for use on pome fruits and was measured in surface water in the vicinity of apple and pear orchards. Temporally, this study found the highest concentrations and greatest frequency of neonicotinoid concentrations in conjunction with the spring freshet, spring rains and crop planting. Bimodal distributions were also observed - likely a result of seasonal insecticide application and the release of residues several months after application.

Research about neonicotinoid surface water contamination indicates a potential for surface water contamination in agricultural regions at concentrations in the parts per billions range (Table 2.8). Given that this group of insecticides has the potential for long-term persistence, mobility and degradation to harmful metabolites, it is critical to assess potential for groundwater contamination (Morrissey et al., 2015).

Table 2.8: Summary of field studies on neonicotinoids in surface water bodies. DF, LOD and, LOQ refer to Detection Frequency, Level of Detection, and Level of Quantitation, respectively. Peak is the maximum concentration that was recorded during each study.

\begin{tabular}{|c|c|c|c|c|c|c|c|}
\hline Medium & Neonicotinoid & Location & $\begin{array}{l}\text { Land Use or } \\
\text { Land-Rate } \\
\text { Application }\end{array}$ & DF (\%) & $\begin{array}{l}\text { LOD } \\
{[\mathrm{LOQ}]} \\
(\mathrm{ppb})\end{array}$ & $\begin{array}{l}\text { Peak } \\
\text { (ppb) }\end{array}$ & Reference \\
\hline $\begin{array}{l}\text { Wetland } \\
\text { sediment }\end{array}$ & $\begin{array}{l}\text { Thiamethoxam } \\
\text { Imidacloprid } \\
\text { Clothianidin } \\
\text { Acetamiprid }\end{array}$ & $\begin{array}{c}\text { Canadian } \\
\text { Prairies }\end{array}$ & $\begin{array}{l}\text { Barley, } \\
\text { canola, } \\
\text { field pea, } \\
\text { wheat }\end{array}$ & $\begin{array}{c}6 \% \text { of } \\
\text { wetland } \\
\text { sites } \\
\text { were } \\
\text { positive }\end{array}$ & $\begin{array}{c}{[0.9]} \\
{[0.55]} \\
{[0.6]} \\
{[0.25]}\end{array}$ & $\begin{array}{c}20.0 \\
17.5 \\
4.4 \\
\text { BDL }\end{array}$ & $\begin{array}{l}\text { Main et al. } \\
(2014)\end{array}$ \\
\hline Wetlands & $\begin{array}{l}\text { Clothianidin } \\
\text { Thiamethoxam } \\
\text { Imidacloprid } \\
\text { Acetamiprid }\end{array}$ & $\begin{array}{c}\text { Canadian } \\
\text { Prairies }\end{array}$ & $\begin{array}{l}\text { Barley, } \\
\text { canola, } \\
\text { field pea, } \\
\text { wheat }\end{array}$ & $\begin{array}{c}87 \\
23 \\
4.8 \\
0\end{array}$ & $\begin{array}{c}{[0.9]} \\
{[0.55]} \\
{[0.6]} \\
{[0.25]}\end{array}$ & $\begin{array}{c}3.11 \\
1.49 \\
0.256 \\
\text { BDL }\end{array}$ & $\begin{array}{l}\text { Main et al. } \\
(2014)\end{array}$ \\
\hline
\end{tabular}




\begin{tabular}{|c|c|c|c|c|c|c|c|}
\hline Wetlands & $\begin{array}{l}\text { Acetamiprid } \\
\text { Thiamethoxam }\end{array}$ & $\begin{array}{l}\text { Southern } \\
\text { High Plains, } \\
\text { USA }\end{array}$ & $\begin{array}{l}\text { Crop Playas } \\
\text { Grassland } \\
\text { Playas }\end{array}$ & $\begin{array}{c}10.5 \\
28\end{array}$ & $\mathrm{~N} / \mathrm{A}$ & $\begin{array}{l}44.1 \\
225\end{array}$ & $\begin{array}{c}\text { T.A. } \\
\text { Anderson et } \\
\text { al. (2013) }\end{array}$ \\
\hline Streams & $\begin{array}{l}\text { Acetamiprid } \\
\text { Imidacloprid } \\
\text { Thiacloprid } \\
\text { Thiamethoxam }\end{array}$ & Sweden & $\begin{array}{l}\text { Vegetables, } \\
\text { fruits, } \\
\text { greenhouses }\end{array}$ & $\begin{array}{c}9 \\
36 \\
0 \\
3\end{array}$ & $\begin{array}{l}0.001 \\
0.013 \\
0.002 \\
0.003\end{array}$ & $\begin{array}{c}0.41 \\
15 \\
\mathrm{BDL} \\
0.16\end{array}$ & $\begin{array}{l}\text { Kreuger et } \\
\text { al. (2010) }\end{array}$ \\
\hline Streams & $\begin{array}{l}\text { Imidacloprid } \\
\text { Dinotefuran }\end{array}$ & $\begin{array}{l}\text { Georgia, } \\
\text { USA }\end{array}$ & $\begin{array}{l}\text { Varied } \\
\text { agricultural } \\
\text { lands }\end{array}$ & $\begin{array}{c}70 \\
0\end{array}$ & $\begin{array}{l}0.0049 \\
0.0055\end{array}$ & $\begin{array}{c}0.035 \\
3 \\
B D L\end{array}$ & $\begin{array}{l}\text { Hladik and } \\
\text { Calhoun } \\
(2012)\end{array}$ \\
\hline Streams & $\begin{array}{l}\text { Clothianidin } \\
\text { Thiamethoxam } \\
\text { Imidacloprid }\end{array}$ & $\begin{array}{l}\text { Midwestern } \\
\text { USA }\end{array}$ & $\begin{array}{l}\text { Corn and } \\
\text { soybeans }\end{array}$ & $\begin{array}{l}75 \\
47 \\
23\end{array}$ & $\begin{array}{l}0.0062 \\
0.0039 \\
0.0049\end{array}$ & $\begin{array}{l}0.257 \\
0.185 \\
<0.00 \\
2\end{array}$ & $\begin{array}{l}\text { Hladik et al. } \\
\qquad(2014)\end{array}$ \\
\hline Streams & Imidacloprid & $\begin{array}{l}\text { Eastern } \\
\text { Canada }\end{array}$ & $\mathrm{N} / \mathrm{A}$ & $\mathrm{N} / \mathrm{A}$ & 0.5 & 11.9 & $\begin{array}{l}\text { Denning et } \\
\text { al. (2004) } \\
\text { Water }\end{array}$ \\
\hline Streams & Imidacloprid & $\begin{array}{c}\text { New } \\
\text { Brunswick, } \\
\text { PEl, and } \\
\text { Nova Scotia, } \\
\text { Canada }\end{array}$ & $\mathrm{N} / \mathrm{A}$ & $\begin{array}{l}4 \text { (NB) } \\
0 \text { (PEI) } \\
0 \text { (NS) }\end{array}$ & $0.1-0.3$ & $\mathrm{~N} / \mathrm{A}$ & $\begin{array}{c}\text { Science and } \\
\text { Technology } \\
\text { Directorate } \\
\text { Environment } \\
\text { Canada } \\
(2011)\end{array}$ \\
\hline Streams & $\begin{array}{l}\text { Imidacloprid } \\
\text { Thiamethoxam } \\
\text { Clothianidin }\end{array}$ & $\begin{array}{l}\text { Quebec, } \\
\text { Canada }\end{array}$ & $\begin{array}{l}\text { Potato, corn, } \\
\text { soy }\end{array}$ & $\begin{array}{l}\text { Varied } \\
\text { per site }\end{array}$ & $\begin{array}{l}0.002 \\
0.002 \\
0.002\end{array}$ & $\begin{array}{c}0.31 \\
1.5 \\
0.26\end{array}$ & $\begin{array}{l}\text { Giroux } \\
(2014)\end{array}$ \\
\hline River & Imidacloprid & Spain & $\begin{array}{l}\text { Olive trees, } \\
\text { cotton, } \\
\text { sugar beet, } \\
\text { wheat, } \\
\text { maize, } \\
\text { sunflower }\end{array}$ & 37.8 & 0.04 [0.2] & $\begin{array}{l}0.019 \\
2\end{array}$ & $\begin{array}{l}\text { Masiá et al. } \\
\text { (2013) }\end{array}$ \\
\hline Ponds & Imidacloprid & $\begin{array}{l}\text { California, } \\
\text { USA }\end{array}$ & $\begin{array}{l}\text { Varied } \\
\text { agricultural } \\
\text { lands }\end{array}$ & 89 & 0.010 & 3.29 & $\begin{array}{l}\text { Starner and } \\
\text { Goh (2012) }\end{array}$ \\
\hline Ponds & $\begin{array}{l}\text { Imidacloprid } \\
\text { Acetamiprid } \\
\text { Thiacloprid } \\
\text { Clothianidin } \\
\text { Thiamethoxam }\end{array}$ & $\begin{array}{l}\text { Southwestern } \\
\text { Ontario }\end{array}$ & Varied & $\begin{array}{c}100 \\
>50 \\
\text { Minimal } \\
80 \\
80\end{array}$ & $\mathrm{~N} / \mathrm{A}$ & $\begin{array}{l}10.4 \\
0.491 \\
0.427 \\
0.399 \\
1.340\end{array}$ & $\begin{array}{l}\text { Struger et } \\
\text { al. (2017) }\end{array}$ \\
\hline Puddles & $\begin{array}{l}\text { Clothianidin } \\
\text { Thiamethoxam }\end{array}$ & $\begin{array}{l}\text { Southwestern } \\
\text { Ontario }\end{array}$ & Maize (corn) & $\begin{array}{l}100 \\
98.7\end{array}$ & $\begin{array}{c}0.023 \\
{[0.063]} \\
0.017 \\
{[0.045]}\end{array}$ & $\begin{array}{l}44.38 \\
\text { (total) }\end{array}$ & $\begin{array}{l}\text { Schaafsma } \\
\text { et al. (2015) }\end{array}$ \\
\hline
\end{tabular}




\begin{tabular}{|c|c|c|c|c|c|c|c|}
\hline $\begin{array}{c}\text { Tile } \\
\text { Drains }\end{array}$ & $\begin{array}{l}\text { Imidacloprid } \\
\text { Clothiaidin } \\
\text { Thiamethoxam }\end{array}$ & Switzerland & $\begin{array}{l}\text { Sugar beet } \\
\text { fields }\end{array}$ & N/A & $\begin{array}{c}0.0001 \\
{[0.0005],} \\
0.0004 \\
{[0.0014],} \\
0.0002 \\
{[0.0007]}\end{array}$ & $\begin{array}{l}1.290 \\
0.053 \\
2.830\end{array}$ & $\begin{array}{l}\text { Wettstein et } \\
\text { al. (2016) }\end{array}$ \\
\hline $\begin{array}{l}\text { Tile } \\
\text { Drains }\end{array}$ & $\begin{array}{l}\text { Clothianidin } \\
\text { Thiamethoxam }\end{array}$ & $\begin{array}{l}\text { Quebec, } \\
\text { Canada }\end{array}$ & $\begin{array}{l}\text { Corn and } \\
\text { soybeans }\end{array}$ & $\begin{array}{l}100 \\
100\end{array}$ & $\begin{array}{l}0.002 \\
0.001\end{array}$ & $\begin{array}{l}0.05 \\
0.44\end{array}$ & $\begin{array}{l}\text { Chrétien et } \\
\text { al. (2017) }\end{array}$ \\
\hline Runoff & $\begin{array}{l}\text { Clothianidin } \\
\text { Thiamethoxam }\end{array}$ & $\begin{array}{l}\text { Quebec, } \\
\text { Canada }\end{array}$ & $\begin{array}{l}\text { Corn and } \\
\text { soybeans }\end{array}$ & $\begin{array}{l}100 \\
100\end{array}$ & $\begin{array}{l}0.002 \\
0.001\end{array}$ & $\begin{array}{l}0.07 \\
2.20\end{array}$ & $\begin{array}{l}\text { Chrétien et } \\
\text { al. (2017) }\end{array}$ \\
\hline
\end{tabular}

\subsubsection{Fate in Groundwater}

While early studies about the environmental fate of neonicotinoids found a limited potential for groundwater contamination (Miles Inc. 1993 as reported in Bacey 2000), more recent research cite a high likelihood of leaching to the saturated zone based on observed surficial behavior and physical properties (Anderson et al., 2015; Bacey, 2000; Fossen, 2006; Goulson, 2013; Gupta et al., 2002; Hladik et al., 2014; Kurwadkar et al., 2013; PMRA, 2016a). Research specifically concerning the presence of neonicotinoids in groundwater (defined as the saturated subsurface layer) are examined in this section.

A study from the 1990s found that imidacloprid was detected in a Long Island, New York, agricultural well at a depth of $5.5 \mathrm{~m}$ (Bayer Corporation, 1998). Imidacloprid concentrations ranged between $0.1 \mu \mathrm{g} / \mathrm{L}$ and $1 \mu \mathrm{g} / \mathrm{L}$ over a five month sampling period. The well was located in a sandy loam soil. These results indicated an early potential for neonicotinoid contamination in groundwater. However, the sampling procedure was not described and no further information on this study is available.

Huseth and Groves (2014) summarized groundwater survey data from the Wisconsin Department of Agriculture, Trade and Consumer Protection from between 2008 and 2012. These surveys were conducted annually at locations considered geologically or hydrologically sensitive to non-point source agrochemical leaching. Up to 30 different wells were monitored annually for acetamiprid, clothianidin, dinotefuran, imidacloprid and thiamethoxam. The regions where the survey was conducted have well-drained, sandy soils and a shallow groundwater table (well depths were not reported). The most common crops in the region are potato, carrots, onions, peas, pepper, cucumber, corn and beans. Thiamethoxam, imidacloprid and clothianidin were repeatedly detected above the level of detection at 23 different well locations. Maximum concentrations of clothianidin, imidacloprid and thiamethoxam were $3.33 \mu \mathrm{g} / \mathrm{L}, 3.34 \mu \mathrm{g} / \mathrm{L}$, and 
$8.93 \mu \mathrm{g} / \mathrm{L}$, respectively. Acetamiprid and dinotefuran were not detected. It was determined that groundwater contamination occurs in areas of intense agricultural activity. The neonicotinoid detection frequencies were not reported.

Lamers et al. (2011) studied imidacloprid concentrations in groundwater near paddy rice fields in Vietnam. During 2008, eight wells were sampled three times during the rice farming season. A field survey revealed that farmers applied an average of $0.12 \mathrm{~kg} / \mathrm{ha}$ imidacloprid in the sampling region. Results showed a maximum imidacloprid concentration of $1.53 \mu \mathrm{g} / \mathrm{L}$ with a detection frequency of $45 \%$. Peak imidacloprid concentrations were found in late August ( 2 to 3 weeks after pesticide application). Drinking and domestic wells were used in this study and screen depths were not provided.

Bortoluzzi et al. (2007) took five samples from four domestic wells between 2001 and 2002 in a Brazilian basaltic rock aquifer. Tobacco farming occurs in the sampling region in spring and summer. This sampling regime found imidacloprid in the spring during seedling transplantation (maximum concentration of $6.22 \mu \mathrm{g} / \mathrm{L}$ with a detection frequency of $25 \%$ ), and in the spring just after tobacco leaves began to sprout $(0.81 \mu \mathrm{g} / \mathrm{L}$ and $58.3 \%$ detection frequency). Soils in this study site have a high clay content. Well depths and land-rate application of imidacloprid were not published.

Weaver and Nordmark (2004) monitored 33 wells between October and November of 2003 in six California counties. Targeted wells had characteristics such as shallow groundwater, permeable soils and a high land-rate application (between $1.36 \mathrm{~kg}$ and $512.1 \mathrm{~kg}$ imidacloprid was applied in the area surrounding each well). No imidacloprid was detected in this study. Well type and depth were not provided.

A follow-up study in California was conducted by Bergin and Nordmark (2009) between February and March of 2009. Imidacloprid was monitored in 34 domestic wells in agricultural-intensive areas with shallow groundwater and soils that facilitate leaching. Known well depths ranged from $5.2 \mathrm{~m}$ to $32.6 \mathrm{~m}$ below ground surface. Land-rate application of neonicotinoids ranged from 14.1 $\mathrm{kg}$ to $547.9 \mathrm{~kg}$ for the years between 1996 and 2003. No neonicotinoids were found above the $0.05 \mu \mathrm{g} / \mathrm{L}$ detection limit.

Felsot (2001) references findings by the United States Environmental Protection Agency that found residues of imidacloprid between $0.1-0.2 \mu \mathrm{g} / \mathrm{L}$ and in groundwater in California and Michigan along with a concentration of $1.9 \mu \mathrm{g} / \mathrm{L}$ in Long Island. No further information on these studies was available. 
Department of Environmental Conservation (2014) reports on monitoring of imidacloprid in New York State groundwater from between 2000 and 2010. This sampling occurred up to four times per year in that time span. Maximum concentrations were approximately $12.5 \mu \mathrm{g} / \mathrm{L}, 0.50 \mu \mathrm{g} / \mathrm{L}$ and $400 \mu \mathrm{g} / \mathrm{L}$ from private water supply wells, public water supply wells, and public monitoring wells, respectively. Temporal patterns show a spike in imidacloprid concentrations in the spring of most years. No information is given on sampling procedure, land use, well depths or detection frequency. This information which is required to understand these anomalously high concentrations

The only published research about neonicotinoid concentrations in Canadian groundwater are Giroux (2003) and Giroux and Sarrasin (2011). Both studies look at a potato-growing region of Quebec with highly conductive sandy soil.

Giroux (2003) annually sampled 28 domestic wells in the fall of 1999, 2000 and 2001. Well depths varied from $1.5 \mathrm{~m}$ to $76 \mathrm{~m}$ with a median depth of $5.7 \mathrm{~m}$. These wells were frequently located on or within $30 \mathrm{~m}$ of a potato farm. Imidacloprid was found in $35 \%$ of wells with a maximum and median concentration of $6.4 \mu \mathrm{g} / \mathrm{L}$ and $0.0385 \mu \mathrm{g} / \mathrm{L}$, respectively.

In the follow-up study, 77 wells (34 agricultural and 43 residential) were sampled between 2008 and 2009. The majority of well depths were less than $9 \mathrm{~m}$ below ground surface. $51 \%$ of these samples were positive for imidacloprid with a maximum concentration of $6.1 \mu \mathrm{g} / \mathrm{L}$. Out of the 25 wells that were sampled in both studies, imidacloprid concentrations increased in 17 wells. Imidacloprid concentrations and detection frequency increased from Giroux (2003) alongside increased imidacloprid sales in Quebec. Thiamethoxam and clothianidin were also measured with respective detection frequencies (maximum concentrations) of $8 \%(0.83 \mu \mathrm{g} / \mathrm{L})$ and $4 \%$ $(0.059 \mu \mathrm{g} / \mathrm{L})$. The only noted temporal trend found that thiamethoxam was at its highest concentration between September 2009 and March 2010. No correlation was found between neonicotinoid contamination and well depth or well distance to potato farms.

Thus, the literature is sparse regarding monitoring of neonicotinoid concentrations in various groundwater settings. A summary of the available research is presented in Table 2.9. 
Table 2.9: Summary of field studies on neonicotinoid concentrations in groundwater. DF, LOD and, LOQ refer to Detection Frequency, Level of Detection, and Level of Quantitation, respectively. Peak is the maximum concentration that was recorded during each study. Aquifer type was only specified in Bortoluzzi et al. (2007).

\begin{tabular}{|c|c|c|c|c|c|c|c|c|}
\hline Neonicotinoids & Location & Soil & $\begin{array}{c}\text { Well } \\
\text { Depth } \\
\text { Range } \\
(\mathrm{m})\end{array}$ & $\begin{array}{l}\text { Land Use } \\
\text { or } \\
\text { Land-Rate } \\
\text { Application }\end{array}$ & $\begin{array}{l}\text { DF } \\
(\%)\end{array}$ & $\begin{array}{c}\text { LOD } \\
{[\text { LOQ] }} \\
(p p b)\end{array}$ & $\begin{array}{l}\text { Peak } \\
\text { (ppb) }\end{array}$ & Reference \\
\hline Imidacloprid & Brazil & Clay & $\mathrm{N} / \mathrm{A}$ & Tobacco & 27.8 & 0.05 & 6.22 & $\begin{array}{l}\text { Bortoluzzi et } \\
\text { al. }(2007)^{*}\end{array}$ \\
\hline Imidacloprid & Vietnam & $\mathrm{N} / \mathrm{A}$ & $\mathrm{N} / \mathrm{A}$ & $\begin{array}{l}0.12 \mathrm{~kg} / \mathrm{ha} \\
\text { Paddy rice }\end{array}$ & 45 & 0.001 & 1.53 & $\begin{array}{l}\text { Lamers et al. } \\
\qquad(2011)\end{array}$ \\
\hline $\begin{array}{l}\text { Acetamiprid } \\
\text { Clothianidin } \\
\text { Dinotefuran } \\
\text { Imidacloprid } \\
\text { Thiamethoxam }\end{array}$ & $\begin{array}{c}\text { Wisconsin, } \\
\text { USA }\end{array}$ & Sandy & $\mathrm{N} / \mathrm{A}$ & $\begin{array}{c}\text { Potato, } \\
\text { carrots, } \\
\text { onions, } \\
\text { peas, } \\
\text { pepper, } \\
\text { cucumber, } \\
\text { corn and } \\
\text { beans }\end{array}$ & $\mathrm{N} / \mathrm{A}$ & $\mathrm{N} / \mathrm{A}$ & $\begin{array}{l}\text { BDL } \\
3.33 \\
\text { BDL } \\
3.34 \\
8.93\end{array}$ & $\begin{array}{l}\text { Huseth and } \\
\text { Groves (2014) }\end{array}$ \\
\hline Imidacloprid & $\begin{array}{c}\text { California, } \\
\text { USA }\end{array}$ & Permeable & $\mathrm{N} / \mathrm{A}$ & $\begin{array}{l}1.36 \mathrm{~kg} \text { to } \\
512.1 \mathrm{~kg}\end{array}$ & 0 & 0.05 & BDL & $\begin{array}{l}\text { Weaver and } \\
\text { Nordmark } \\
(2004)\end{array}$ \\
\hline Imidacloprid & $\begin{array}{c}\text { California, } \\
\text { USA }\end{array}$ & Permeable & $\begin{array}{l}5.2- \\
32.6\end{array}$ & $\begin{array}{c}14.1 \mathrm{~kg} \text { to } \\
547.9 \mathrm{~kg}\end{array}$ & 0 & 0.05 & BDL & $\begin{array}{c}\text { Bergin and } \\
\text { Nordmark } \\
(2004)\end{array}$ \\
\hline Imidacloprid & $\begin{array}{l}\text { California, } \\
\text { USA } \\
\text { Michigan, } \\
\text { USA }\end{array}$ & $\mathrm{N} / \mathrm{A}$ & $\mathrm{N} / \mathrm{A}$ & N/A & $\mathrm{N} / \mathrm{A}$ & $\mathrm{N} / \mathrm{A}$ & $\begin{array}{c}0.1- \\
0.2\end{array}$ & Felsot (2001) \\
\hline Imidacloprid & $\begin{array}{l}\text { Long } \\
\text { Island, } \\
\text { USA }\end{array}$ & $\mathrm{N} / \mathrm{A}$ & $\mathrm{N} / \mathrm{A}$ & $\mathrm{N} / \mathrm{A}$ & $\mathrm{N} / \mathrm{A}$ & $\mathrm{N} / \mathrm{A}$ & 1.9 & Felsot (2001) \\
\hline Imidacloprid & $\begin{array}{l}\text { Long } \\
\text { Island, } \\
\text { USA }\end{array}$ & Varied & $\mathrm{N} / \mathrm{A}$ & $N / A$ & $\mathrm{~N} / \mathrm{A}$ & $\mathrm{N} / \mathrm{A}$ & 400 & $\begin{array}{c}\text { Department of } \\
\text { Environmental } \\
\text { Conservation } \\
(2014)\end{array}$ \\
\hline Imidacloprid & $\begin{array}{l}\text { Quebec, } \\
\text { Canada }\end{array}$ & Sandy & $1.5-76$ & Potato & 35 & 0.002 & 6.4 & Giroux (2003) \\
\hline $\begin{array}{l}\text { Imidacloprid } \\
\text { Thiamethoxam } \\
\text { Clothianidin }\end{array}$ & $\begin{array}{l}\text { Quebec, } \\
\text { Canada }\end{array}$ & Sandy & $\begin{array}{l}\text { Majority } \\
\text { less } \\
\text { than } 9 \\
\text { mBGS }\end{array}$ & Potato & $\begin{array}{c}51 \\
8 \\
4\end{array}$ & $\begin{array}{l}0.002 \\
0.002 \\
0.002\end{array}$ & $\begin{array}{c}6.1 \\
0.83 \\
0.059\end{array}$ & $\begin{array}{c}\text { Giroux \& } \\
\text { Sarrasin } \\
(2011)\end{array}$ \\
\hline
\end{tabular}

${ }^{\star}$ Study conducted in a basaltic rock aquifer underlying soil with good drainage

It is difficult to make broad statements about patterns concerning the detection of neonicotinoids in groundwater. Detection frequencies are typically much lower in groundwater when compared to surface water; using the data from sample studies summarized in Table 2.8 and Table 2.9, a mean neonicotinoid detection frequency of $17.9 \%$ and $42.4 \%$ exists for groundwater and 
surface water, respectively. The presence of neonicotinoids can be positively correlated with land-rate application of the insecticide for both groundwater and surface water. It should be noted that there is no Canadian reference value for neonicotinoids in groundwater; however, past studies have shown that imidacloprid can be found in groundwater above the freshwater reference value of $0.36 \mu \mathrm{g} / \mathrm{L}$ (Bayer Corporation, 1998; Bortoluzzi et al., 2007; Department of Environmental Conservation, 2014; Felsot, 2001; Giroux, 2003; Giroux and Sarrasin, 2011; Huseth and Groves, 2014; Lamers et al., 2011). This suggests that there may be some value in conducting further research to fill knowledge gaps about the presence of neonicotinoids in Canadian groundwater.

\subsection{Knowledge Gaps and Recommendations}

The potential for the persistence and mobility of neonicotinoids in the environment is well documented. Due to low application rates, neonicotinoids are typically found in soil, surface water, and groundwater at concentrations in the parts-per-billion range, which initially led to the perception that they are environmentally-friendly.

Alongside reports about the potential for neonicotinoids to harm non-target species (such as aquatic invertebrates and pollinators) at low concentrations, these insecticides are being studied more extensively for their ability to travel as dust drift, persist in soil and travel into aquatic bodies. The bulk of the research on aquatic bodies has focused on the ability of these insecticides to travel into surface water such as ponds, streams and puddles.

The body of knowledge about neonicotinoids in groundwater is far less robust. Research analyzing the presence of neonicotinoids in groundwater often omit pertinent information such as surface data (soil type, land use, land-rate application), spatial/temporal contamination patterns, along with aquifer and well characteristics. In addition to this, research about groundwater contamination by neonicotinoids, with the exception of imidacloprid, is inadequate.

Based on the information reviewed in this paper, the knowledge gaps surrounding neonicotinoids in groundwater is depicted in Figure 2.1. 


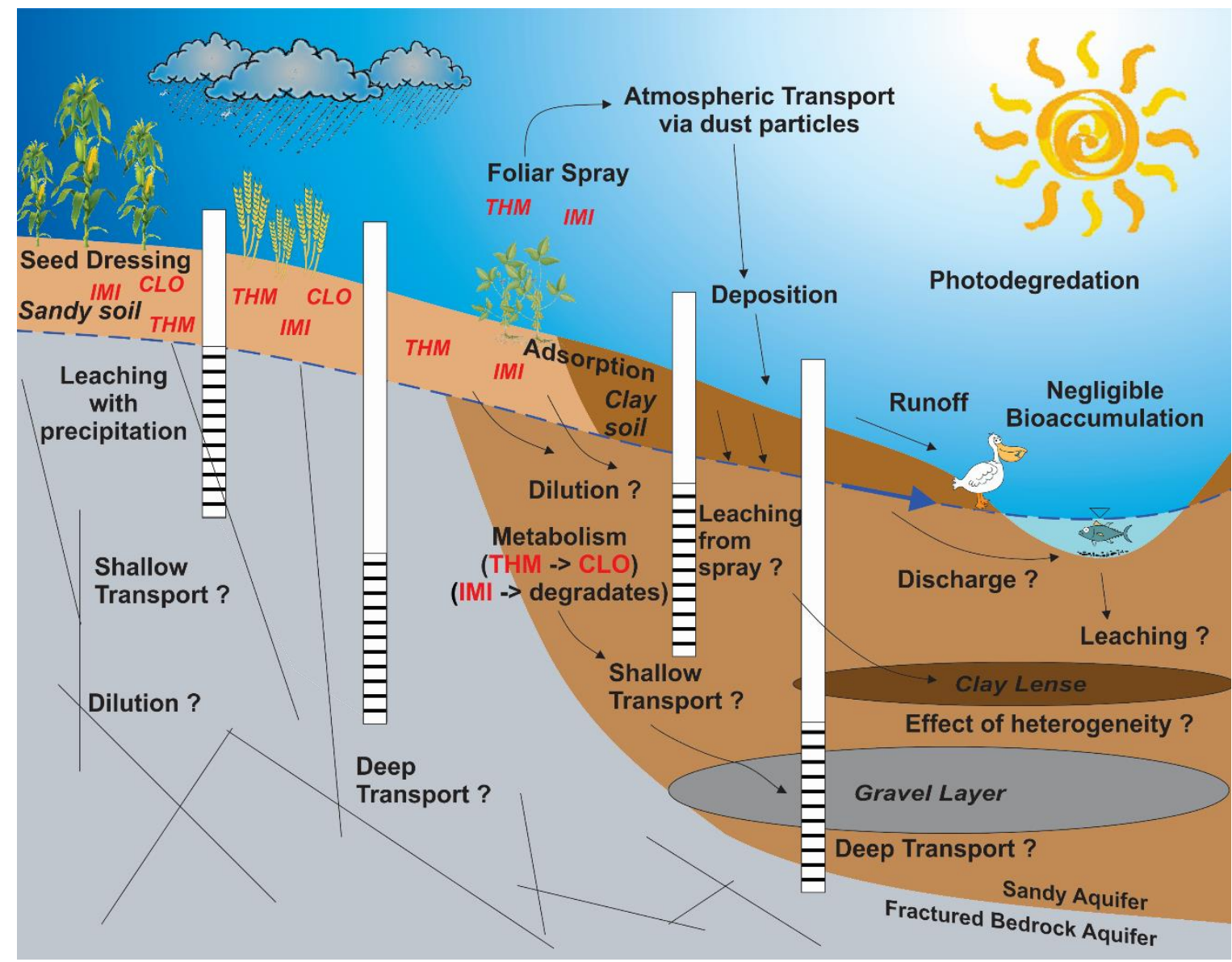

Figure 2.1: Conceptual diagram that depicts the current state of knowledge into the fate of neonicotinoids in groundwater and the environment. This diagram has been developed for the Ontario, Canada context. Clothianidin, imidacloprid and thiamethoxam are represented by CLO, IMI, and THM, respectively.

Knowledge gaps, highlighted in the conceptual diagram, necessitate future research on the presence of neonicotinoids in groundwater. The following issues should be addressed:

1. Spatial distribution of neonicotinoids in groundwater at both local and regional scales.

2. Temporal patterns of neonicotinoids in groundwater through intensive seasonal sampling;

3. Links between surface material and groundwater contamination. Surface material includes soil type and land use.

4. The effect of aquifer material on neonicotinoid contamination.

5. The presence of neonicotinoids in groundwater at different depths.

6. The potential for neonicotinoid contamination in groundwater to be discharged to the surface where it can harm non-target species. 


\subsection{References}

Anderson, T.A., Salice, C.J., Erickson, R.A., McMurry, S.T., Cox, S.B., Smith, L.M., 2013.

Effects of landuse and precipitation on pesticides and water quality in playa lakes of the southern high plains. Chemosphere 92, 84-90. doi:10.1016/j.chemosphere.2013.02.054

Anderson, Dubetz, C., Palace, V.P., 2015. Neonicotinoids in the Canadian aquatic environment:

A literature review on current use products with a focus on fate, exposure, and biological effects.

Sci. Total Environ. doi:10.1016/j.scitotenv.2014.09.090

Arkins, E., 2015. Ontario restricts use of pesticides blamed for decline of bee populations. Globe Mail 2015-2016.

Bacey, J., 2000. Environmental Fate of Imidacloprid. Sacramento.

Bayer Corporation, 1998. Imidacloprid Memo to U.S. EPA.

Bergin, R., Nordmark, C., 2009. GW 09 : Ground Water Monitoring for Imidacloprid and Four Degradates in High Use Areas in California.

Bonmatin, J.M., Giorio, C., Girolami, V., Goulson, D., Kreutzweiser, D.P., Krupke, C., Liess, M., Long, E., Marzaro, M., Mitchell, E.A., Noome, D.A., Simon-Delso, N., Tapparo, A., 2015.

Environmental fate and exposure; neonicotinoids and fipronil. Environ. Sci. Pollut. Res. 22, 3567. doi:10.1007/s11356-014-3332-7

Bortoluzzi, E.C., Rheinheimer, D.S., Gonçalves, C.S., Pellegrini, J.B.R., Maroneze, A.M., Kurz, M.H.S., Bacar, N.M., Zanella, R., 2007. Investigation of the occurrence of pesticide residues in rural wells and surface water following application to tobacco. Quim. Nova 30, 1872-1876. doi:10.1590/S0100-40422007000800014

Canadian Council of Ministers of the Environment, 2007. Canadian Water Quality Guidelines for the Protection of Aquatic Life - Imidacloprid. Can. Environ. Qual. Guidel.

Chrétien, F., Giroux, I., Thériault, G., Gagnon, P., Corriveau, J., 2017. Surface runoff and subsurface tile drain losses of neonicotinoids and companion herbicides at edge-of-field. Environ. Pollut. 1-10. doi:10.1016/j.envpol.2017.02.002

Decant, J., 2010. Clothianidin registration of Prosper T400 seed treatment on mustard seed (oilseed and condiment) and Poncho/Votivo seed treatment on cotton. Washington, D.C. 
Denning, A., Ernst, W.R., Julien, G.R., Doe, K.G., Cook, A., Bernier, M., Jackman, P., Loiser, C., 2004. An assessment of buffer zone effectiveness in reducing pesticide runoff from potato fields in Prince Edward Island (2001-2002).

Department of Environmental Conservation, 2014. Long Island Pesticide Pollution Prevention Strategy.

Engan, I., 2016. The Effect of pH, Dissolved Metals and Suspended Minerals on the Hydrolysis of Neonicotinoids.

Felsot, A., 2001. Imidacloprid: Insecticide on the Move. Agrichem. Environ. News Index.

Food and Agriculture Organization of the United Nations and World Health Organization, 2011. Pesticide residues in food 2010. Evaluations Part I - Residues. Rome.

Fossen, M., 2006. Environmental Fate of Imidacloprid. Regulation 1-16.

Giroux, I., 2014. Présence de pesticides dans l'eau au Québec- Zones de vergers et de pommes de terre, 2010 à 2012. Québec.

Giroux, I., 2003. Contamination de l'eau souterraine par les pesticides et les nitrates dans les régions en culture de pommes de terre, Campagnes d'Echantillonage.

Giroux, I., Sarrasin, B., 2011. Pesticides et nitrates dans l'eau souterraine près de cultures de pommes de terre - Échantillonnage dans quelques régions du Québec en 2008 et 2009.

Godfray, Blacquière, T., Field, L.M., Hails, R.S., Petrokofsky, G., Potts, S.G., Raine, N.E., Vanbergen, a. J., McLean, a. R., 2014. A restatement of the natural science evidence base concerning neonicotinoid insecticides and insect pollinators. Proc. R. Soc. B Biol. Sci. 281, 20140558. doi:10.1098/rspb.2014.0558

Goulson, D., 2013. An overview of the environmental risks posed by neonicotinoid insecticides. J. Appl. Ecol. 50, 977-987. doi:10.1111/1365-2664.12111

Government of Ontario, 2009. Ontario Pesticide Act. Canada.

Gunderson, D., Bunbar, E., 2016. Seeking to reverse bee decline, Dayton orders limits on pesticide use [WWW Document]. MPR News. URL https://www.mprnews.org/story/2016/08/26/dayton-orders-steps-protect-bees-pollinators (accessed 1.23.17). 
Gupta, S., Gajbhiye, V.T., Agnihotri, N.P.K., 2002. Leaching behaviour of imidacloprid formulations in soil, Bull. Environ. Contam. Toxicol. 68, 502-508. doi:10.1007/s00128-0010283-8

Health Canada, 2014. Pest Control Products Sales Report for 2014. Ottawa.

Health Canada, 2011. Pest Control Products Sales Report for 2011. Ottawa.

Health Canada, 2008. Pest Control Products Sales Report for 2007 and 2008. Ottawa.

Hladik, M., Kolpin, D., 2015. First national-scale occurrence of neonicotinoid insecticides in streams across the U.S.A. Environ. Chem. 12-20. doi:10.1071/EN15061

Hladik, M., Kolpin, D.W., Kuivila, K.M., 2014. Widespread occurrence of neonicotinoid insecticides in streams in a high corn and soybean producing region, USA. Environ. Pollut. 193, 189-196. doi:10.1016/j.envpol.2014.06.033

Huseth, A.S., Groves, R.L., 2014. Environmental fate of soil applied neonicotinoid insecticides in an irrigated potato agroecosystem. PLoS One 9. doi:10.1371/journal.pone.0097081

Junior, R.P.S., Smelt, J.H., Boeston, J.J.T.I., Hendriks, R.F.A., Zee, S.E.A.T.M. van der, 2004. Vadose Zone Processes and Chemical Transport. J. Environ. Qual. 33, 1033-1040.

Kohn, J., Soto, D.X., Iwanyshyn, M., Olson, B., Kalischuk, A., Lorenz, K., Hendry, M.J., 2015. Groundwater nitrate and chloride trends in an agriculture-intensive area in southern Alberta, Canada. Water Qual. Res. J. Canada wqrjc2015132. doi:10.2166/wqrjc.2015.132

Kreuger, J., Graaf, S., Patring, J., Adielsson, S., 2010. Pesticides in surface water in areas with open ground and greenhouse horticultural crops in Sweden 2008. Swedish Univ. Agric. Sci. 49. Kurwadkar, S., Dewinne, D., Wheat, R., McGahan, D.G., Mitchell, F.L., 2013. Time dependent sorption behavior of dinotefuran, imidacloprid and thiamethoxam. J. Environ. Sci. Health. B. 48, 237-42. doi:10.1080/03601234.2013.742412

Kurwadkar, S., Evans, A., 2016. Neonicotinoids: Systemic Insecticides and Systematic Failure. Bull. Environ. Contam. Toxicol. 97, 745-748. doi:10.1007/s00128-016-1968-3

Lamers, M., Anyusheva, M., La, N., Nguyen, V.V., Streck, T., 2011. Pesticide Pollution in Surface- and Groundwater by Paddy Rice Cultivation: A Case Study from Northern Vietnam. Clean - Soil, Air, Water 39, 356-361. doi:10.1002/clen.201000268 
Levison, J.K., Novakowski, K.S., 2012. Rapid transport from the surface to wells in fractured rock: A unique infiltration tracer experiment. J. Contam. Hydrol. 131, 29-38.

doi:10.1016/j.jconhyd.2012.01.001

Limay-Rios, V., Forero, L.G., Xue, Y., Smith, J., Baute, T., Schaafsma, A., 2016. Neonicotinoid insecticide residues in soil dust and associated parent soil in fields with a history of seed treatment use on crops in southwestern Ontario. Environ. Toxicol. Chem. 35, 303-310. doi:10.1002/etc.3257

Lockhart, K.M., King, A.M., Harter, T., 2013. Identifying sources of groundwater nitrate contamination in a large alluvial groundwater basin with highly diversified intensive agricultural production. J. Contam. Hydrol. 151, 140-154. doi:10.1016/j.jconhyd.2013.05.008

Maienfisch, P., 2006. Synthesis and properties of 3,6-dideoxyhexulosonic acids and related compounds. Zeitschrift für Naturforsch. 61b, 353-359. doi:10.1016/S0008-6215(00)80155-X

Maienfisch, P., Angst, M., Brandl, F., Fischer, W., Hofer, D., Kayser, H., Kobel, W., Rindlisbacher, A., Senn, R., Steinemann, A., Widmer, H., 2001. Chemistry and biology of thiamethoxam: A second generation neonicotinoid. Pest Manag. Sci. 57, 906-913. doi:10.1002/ps.365

Main, A.R., Headley, J. V., Peru, K.M., Michel, N.L., Cessna, A.J., Morrissey, C.A., 2014. Widespread use and frequent detection of neonicotinoid insecticides in wetlands of Canada's prairie pothole region. PLoS One 9. doi:10.1371/journal.pone.0092821

Matsuda, K., Buckingham, S.D., Kleier, D., Rauh, J.J., Grauso, M., Sattelle, D.B., 2001. Neonicotinoids: Insecticides acting on insect nicotinic acetylcholine receptors. Trends Pharmacol. Sci. 22, 573-580. doi:10.1016/S0165-6147(00)01820-4

Mineau, P., Palmer, C., 2013. The Impact of the Nation's Most Widely Used Insecticides on Birds.

Morrissey, C.A., Mineau, P., Devries, J.H., Sanchez-Bayo, F., Liess, M., Cavallaro, M.C., Liber, K., 2015. Neonicotinoid contamination of global surface waters and associated risk to aquatic invertebrates: A review. Environ. Int. doi:10.1016/j.envint.2014.10.024

Neshat, A., Pradhan, B., Pirasteh, S., Shafri, H.Z.M., 2014. Estimating groundwater vulnerability to pollution using a modified DRASTIC model in the Kerman agricultural area, Iran. Environ. Earth Sci. 71, 3119-3131. doi:10.1007/s12665-013-2690-7 
OMAFRA, 2016. Field Crop Protection Guide 2016-2017, 812. Guelph.

Ontario Ministry of Agriculture, Food and Rural Affairs, 2016. Publication 812, Field Crop

Protection Guide 2016-2017.

Paradis, D., Vigneault, H., Lefebvre, R., Savard, M.M., Ballard, J.M., Qian, B., 2016.

Groundwater nitrate concentration evolution under climate change and agricultural adaptation scenarios: Prince Edward Island, Canada. Earth Syst. Dyn. 7, 183-202. doi:10.5194/esd-7-1832016

PMRA, 2016a. Imidacloprid - Proposed Re-Evaluation Decision. Ottawa.

PMRA, 2016b. Initiation of Special Reviews: Potential Environmental Risk to Aquatic Invertebrates Related to the Use of Clothianidin and Thiamethoxam. Ottawa.

Schaafsma, A., Limay-Rios, V., Baute, T., Smith, J., Xue, Y., 2015. Neonicotinoid insecticide residues in surface water and soil associated with commercial maize (corn) fields in Southwestern Ontario. PLoS One 10,1-21. doi:10.1371/journal.pone.0118139

Schaafsma, A., Limay-Rios, V., Xue, Y., Smith, J., Baute, T., 2016. Field-scale examination of neonicotinoid insecticide persistence in soil as a result of seed treatment use in commercial maize (corn) fields in southwestern Ontario. Environ. Toxicol. Chem. 35, 295-302. doi:10.1002/etc.3231

Sheets, L.P., 2010. Imidacloprid: A Neonicotinoid Insecticide. Hayes' Handb. Pestic. Toxicol. 2055-2064. doi:10.1016/B978-0-12-374367-1.00095-1

Starner, K., Goh, K.S., 2012. Detections of the neonicotinoid insecticide imidacloprid in surface waters of three agricultural regions of California, USA, 2010-2011. Bull. Environ. Contam. Toxicol. 88, 316-321. doi:10.1007/s00128-011-0515-5

Stewart, G., Baute, T., Lead, P., 2013. Neonicotinoids and Field Crop Production in Ontario [WWW Document]. URL http://www.omafra.gov.on.ca/english/about/beehealthpresentations/omafcrop.htm (accessed 1.17.17).

Struger, J., Grabuski, J., Cagampan, S., Sverko, E., McGoldrick, D., Marvin, C.H., 2017. Factors influencing the occurrence and distribution of neonicotinoid insecticides in surface waters of southern Ontario, Canada. Chemosphere 169, 516-523. doi:10.1016/j.chemosphere.2016.11.036 
Taylor, A.G., Harman, G.E., 1990. Concepts and Technologies of Selected Seed Treatments. Annu. Rev. Phytopathol. 28, 321-339. doi:10.1146/annurev.py.28.090190.001541

Unglesbee, E., 2017. Neonic Update - EPA Releases Flurry of Risk Assessments for Neonics. DTN.

US EPA, 1993. EFGWB Review of imidacloprid. Washington, D.C.

Weaver, D., Nordmark, C., 2004. Summary of Results for Fiscal Year 2003/04 Ground Water Protection List Monitoring for Imidacloprid and Three of it's Degradates, Memorandum to Bob Rollins. Sacramento.

Wettstein, F.E., Kasteel, R., Garcia Delgado, M.F., Hanke, I., Huntscha, S., Balmer, M.E., Poiger, T., Bucheli, T.D., 2016. Leaching of the Neonicotinoids Thiamethoxam and Imidacloprid from Sugar Beet Seed Dressings to Subsurface Tile Drains. J. Agric. Food Chem. 64, 64076415. doi:10.1021/acs.jafc.6b02619 


\section{Site History}

Research sites selected for this project are located in Norfolk County and Lanark County in Ontario, Canada (Figure 3.1). Norfolk County has a shallow, unconfined granular aquifer while the groundwater in Lanark County resides in the Canadian Shield with a gneissic aquifer and thin overburden (generally less than $1 \mathrm{~m}$, but ranging from $0 \mathrm{~m}$ to $8 \mathrm{~m}$ at TW3 and TW5, respectively). These two distinct sites were chosen due to their contrasting hydrogeologic settings and past evidence of groundwater vulnerability to agricultural contaminants (Hollingham, 2011; Levison et al., 2012; Levison and Novakowski, 2009; Macdonald, 2015). All wells at both research sites were drilled between 2004 and 2011 for previous studies. This chapter provides a detailed overview of these two research sites.

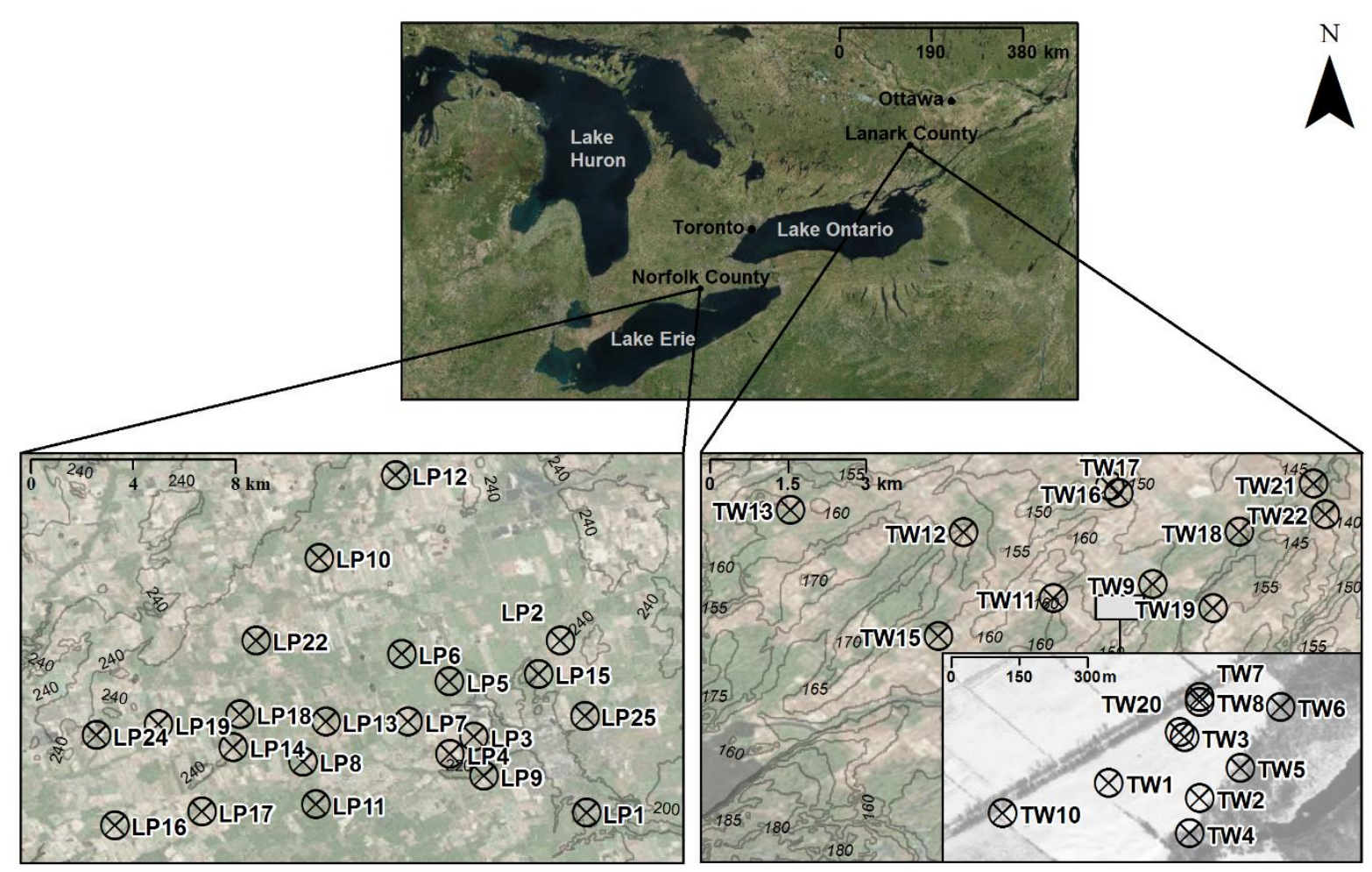

Figure 3.1: The location of each research site in southern Ontario, Canada (upper image). Norfolk County, bottom left, is shown with monitoring wells that are referenced as 'LP'. LP20, LP21, LP23, and LP26 reside west of the domain and were not included in this study. The Lanark County research site, bottom right, is shown with the well cluster in a hay field enlarged in the bottom right corner. All wells in Lanark County are referenced as 'TW'. The elevation is contoured in metres above sea level at both research sites.

\subsection{Norfolk County}

\subsubsection{Site Description}

The research site in Norfolk County is located predominantly between the municipalities of Delhi and Simcoe (Figure 3.2). It consists of 26 multi-level wells (58 monitoring intervals) within the 140,000 ha extent. These well clusters were installed by the Grand River Conservation Authority 
and Norfolk County for the Long Point Tier Three Water Budget Study (Matrix Solutions Inc., 2015). All wells are $85 \mathrm{~mm}$ in diameter and were drilled using track mounted drill rigs between September of 2010 and January of 2011 (Appendix A - Well Data). Grout, holeplugs, and \#2 silica sand were used to isolate each interval. These wells are henceforth referenced as Long Point Monitoring Wells, or "LP-MW".

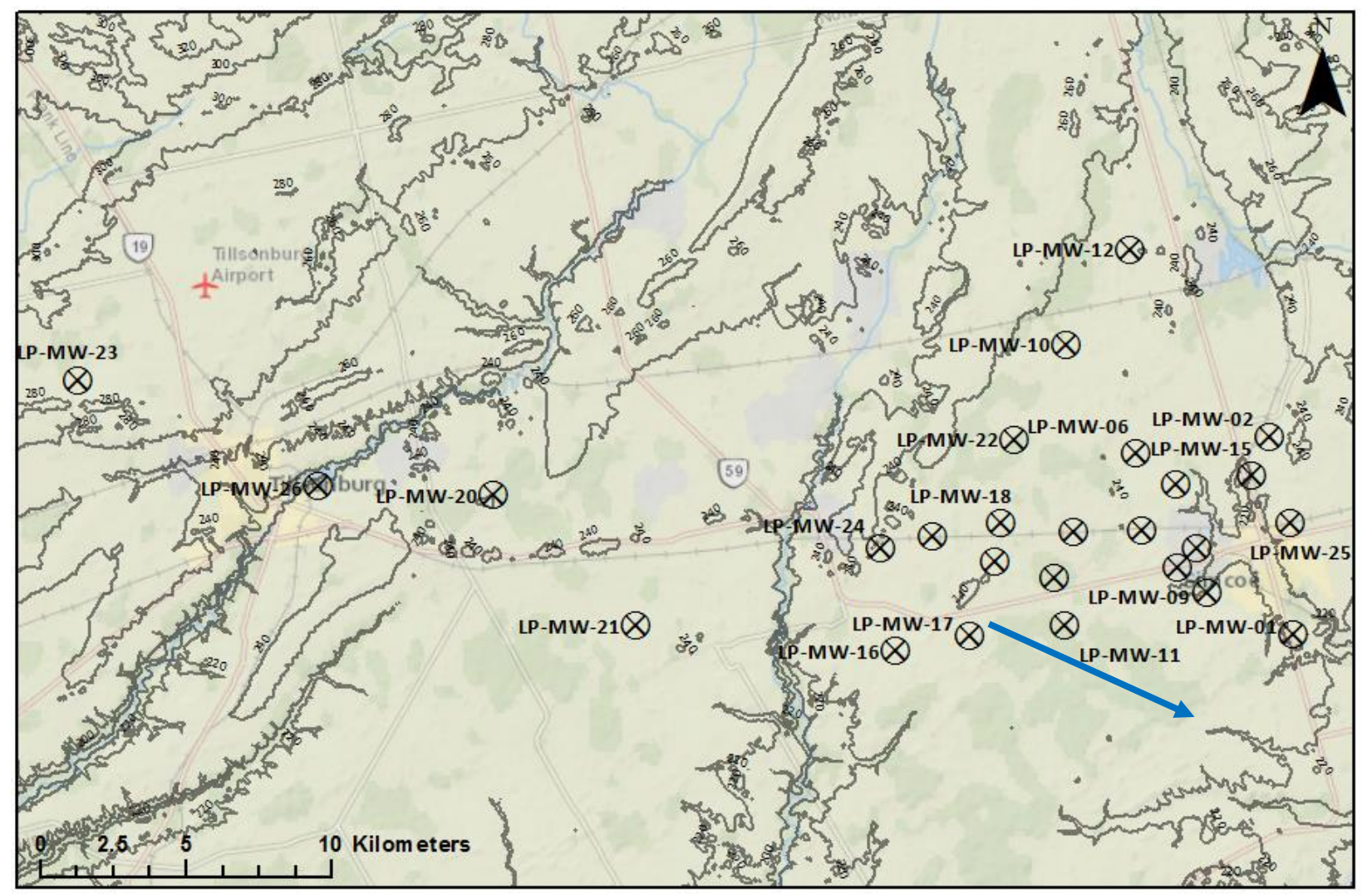

Figure 3.2: Location of the 26 multi-level Long Point Monitoring Wells in Norfolk County. Regional groundwater flow (indicated by the blue arrow) is derived from April 2016 static water levels. Digital elevation data is displayed in units of meters above sea level and was obtain from Natural Resources Canada (2017).

Norfolk County is an agricultural-intensive region with approximately $78 \%$ of the land actively farmed (LPRCA, 2008). Typical crops in the region include corn, soybeans, ginseng, tobacco, and wheat. Due to the combination of intensive agriculture and sandy soil with good drainage, the regional Norfolk Sand Plain aquifer has been characterized as highly vulnerable to contamination (LPRCA, 2008). This characterization poses issues because $45 \%$ of the Norfolk County population relies on a municipal groundwater distribution system, while another $25 \%$ rely on private wells for potable water use (Matrix Solutions Inc., 2013). 


\subsubsection{Geology and Climate}

The bedrock geology in Norfolk County is composed of limestone and dolostone that was deposited between 280 and 425 million years ago (Armstrong and Carter, 2010). Quaternary geology consists of the Horseshoe Moraine and Mount Elgin, the Norfolk Sand Plain, and the Haldimand Sand Plain. Within the confines of the research site, the Norfolk Sand Plain dominates. This low-relief plain is composed of silty sand and gravel sediments that are up to $27 \mathrm{~m}$ thick (LPRCA, 2008). Deposition of the Norfolk Sand Plain began between 17,000 and 25,000 years ago (Marich, 2010).

In order to evaluate the vulnerability of groundwater resources for the Tier Three study, the Norfolk Sand Plain was assessed and assigned sedimentary packages across the extent of the study domain (Marich, 2010). The Ontario Geological Survey delineated seven sedimentary packages as summarized in Table 3.1 .

Table 3.1: Sedimentary packages across the central Norfolk Sand Plain, as per Marich (2010).

\begin{tabular}{cc}
\hline Sedimentary Package & Description \\
\hline Catfish Creek Till & Massive and compact sandy-silt diamicton \\
Erie Phase Deposits & Discontinuous clay, silt to fine-textured sands \\
Port Stanley Till & Patchy sandy silt to clayey silt diamicton \\
Fine-textured Erie basin deposits & Silt, clay, and laminated silt, clay and fine-textured sands \\
Coarse-textured Lake Ypsilanti & Medium- to coarse-textured sands and gravels \\
low level deposits & \\
Fine to medium-textured Erie & Coarsening upward clay, silt to medium-textured sands \\
Basin deposits & Discontinuous silt, very fine-textured sands, and clay \\
Wentworth Till &
\end{tabular}

Generally, fine to medium-textured Erie Basin deposits overlie Port Stanley till to the west and fine-textured Erie Basin deposits in the central and eastern plain extents. These are underlain by a thin layer of fine-textured Erie phase deposits and Catfish Creek till before Paleozoic bedrock is encountered. Wentworth till and course-textured Lake Ypsilanti low level deposits are encountered unevenly across the eastern portion of the plain (Figure 3.3). 


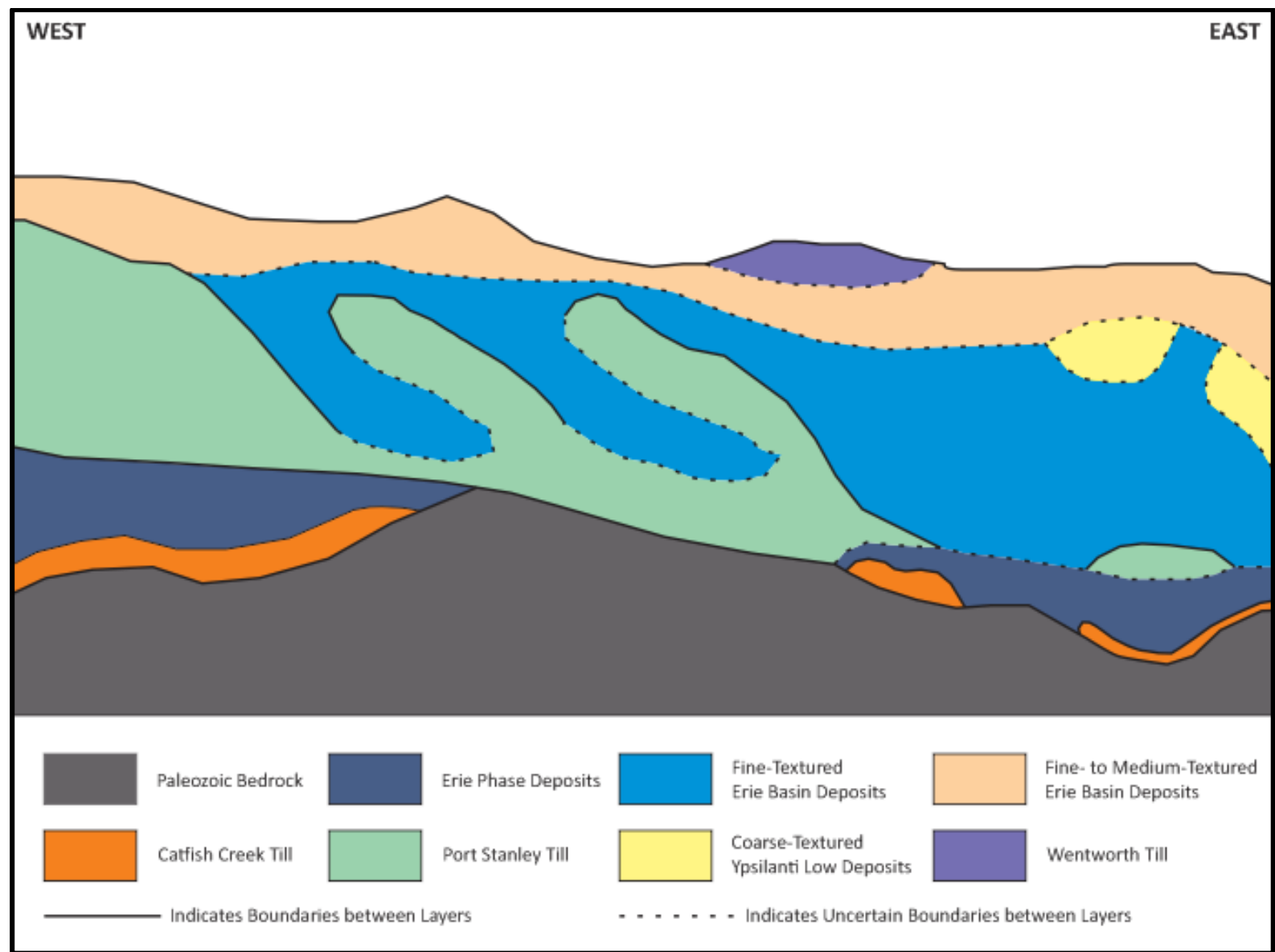

Figure 3.3: Generalized conceptual model of the central Norfolk Sand Plain, adapted from Marich (2010). Cross section is oriented from west to east.

The local soils within the Norfolk Sand Plain are predominantly high permeability coarse-grained sand with some fine-grained areas (Figure 3.4). These well-drained soils are ideally suited for the intensive agriculture that occurs throughout Norfolk County (Matrix Solutions Inc., 2013). 


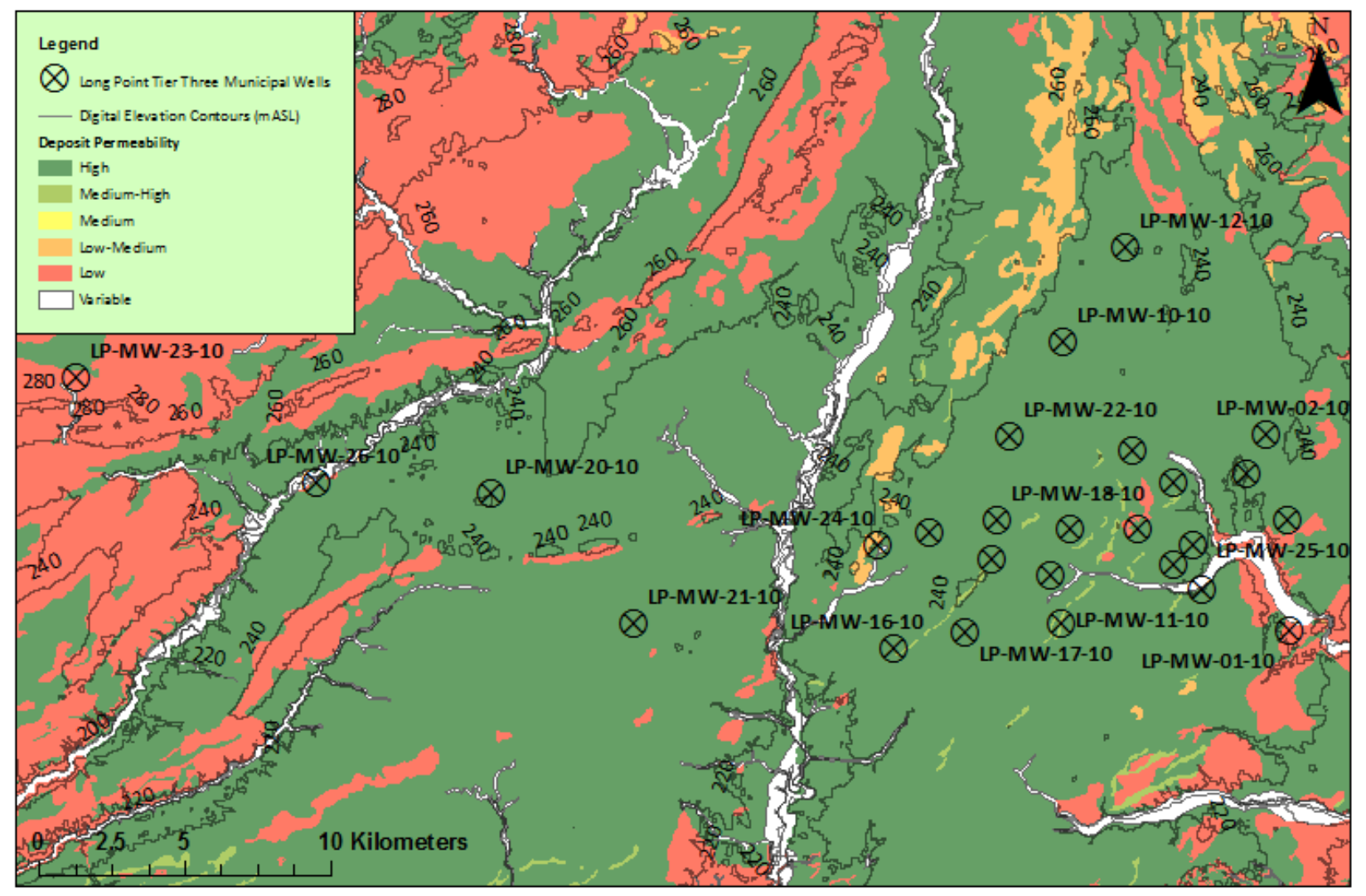

Figure 3.4: Permeability of the quaternary geology within the confines of the Norfolk County study site (Ontario Geological Survey, 2010). Low permeability Port Stanley Till lies along the northwest extents of the study site, while the high permeability coarse-textured glaciolacustrine deposits dominate the central and southeastern limits of the region. The Paris Moraine is interpreted as a low permeability zone in the northeast corner while varied alluvial deposits acts a divide across the study region.

Groundwater elevations are between $1.5 \mathrm{~m}$ and $10.3 \mathrm{~m}$ below ground surface throughout the year at the research site. The Norfolk Sand Plain has high groundwater recharge (average annual recharge of $224 \mathrm{~mm} /$ year) and low runoff (Matrix Solutions Inc., 2015). Regionally, groundwater flow generally follows the gently undulating topography unless impeded by geologic conditions or local changes in relief (Matrix Solutions Inc., 2013). Negligible differences in water level between separate aquifers suggest that aquitards are discontinuous at a regional scale. Connectivity between aquifers provides a potential path for contaminant transport (Marich, 2010).

The climate in Norfolk County is humid temperate continental with cold winters and hot summers. The proximity to Lake Erie provides a moderating effect throughout the year. Average monthly temperature and precipitation between 1981 and 2010 ranges from $-5.4^{\circ} \mathrm{C}$ to $21.1^{\circ} \mathrm{C}$ and from $62.7 \mathrm{~mm}$ to $110.5 \mathrm{~mm}$, respectively (Government of Canada, 2017). 


\subsection{Previous Studies}

Several studies have used the Tier Three wells in Norfolk County to evaluate water budgets and agricultural contamination in the region. Marich (2010) used the Tier Three boreholes to develop sedimentary packages that were developed into conceptual and numerical water budget models (Matrix Solutions Inc., 2014, 2013). Macdonald (2015) used the monitoring wells to evaluate new technologies in measuring nitrate throughout the region.

The Tier Two Water Quantity Stress Assessment was conducted in 2009 (AquaResource Inc., 2009). This report involved a regional continuous streamflow model using GAWSER and steady-state groundwater flow model using FEFLOW. This assessment found that groundwater in Simcoe, Waterford, and Tillsonburg, along with groundwater and surface water in Delhi, have a moderate or significant potential for hydrologic stress (AquaResource Inc., 2009). As a result, a Tier Three study was conducted and the Long Point Monitoring Wells were drilled in 2009-2010. Based on these borehole logs, stratigraphic packages were developed by the Ontario Geological Survey (Marich, 2010). Hydrogeological studies conducted prior to the publication of these packages are not reviewed in this report.

The first step of the Tier Three study involved updating the FEFLOW model to include this revised stratigraphic information. This resulted in the removal of the Tillsonburg subwatershed from the Tier Three study because these revised assessments found a low potential for hydrologic stress in the area (Matrix Solutions Inc., 2013). A regional-scale and several local-scale integrated surface and groundwater flow models were then developed using MIKE SHE (Matrix Solutions Inc., 2014). This conceptual and numerical modelling found that most areas within the study zone have a low risk of water quantity threats. One area was found to have significant threats to its water supply (a small region within the eastern extents of Simcoe). Recommendations from this report include maintaining and rehabilitating/updating wells, along with enacting water conservation programs and monitoring programs.

Research into Norfolk County groundwater quality have found nitrate concentrations ranging from below the detection limit to $23.1 \mathrm{mg} / \mathrm{L}$ (Hollingham, 2011). The nitrogen source was linked to fertilizer-derived ammonium at most wells; nitrate from septic sources was detected at LP-MW-04. Nitrate contamination spikes have occurred in the early spring and after harvest in the fall before subsiding during the winter months (Macdonald, 2015). Further studies into conceptual and numerical models are ongoing and forthcoming (e.g. Gardner (2017); Saleem et al. (2016)). 


\subsection{Lanark County}

\subsubsection{Site Description}

The research site in Lanark County is located in the Tay River Watershed near a stretch of the Tay River in Glen Tay ( $7 \mathrm{~km}$ southwest of Perth, Ontario). The 21 multi-level wells (52 monitoring intervals) are located within a 3400 ha area in Glen Tay; ten of these wells are located within a 5 ha hay field (Figure 3.5). All well casings are $0.15 \mathrm{~m}$ in diameter and were drilled with an air rotary rig (Appendix A - Well Data). Casing was installed into the upper $0.5 \mathrm{~m}$ of competent bedrock. Thirteen wells within the study region were completed as nested wells with three multi-level piezometers using $0.05 \mathrm{~m}$ diameter PVC pipes with bentonite and \#2 sand to isolate each interval. Four wells were completed with two multi-level nested piezometers while four more were left open. These wells are herein referenced as Tay River Watershed wells, or "TW". Overburden thickness encountered during drilling ranged from $0 \mathrm{~m}$ to $8 \mathrm{~m}$. The thickest overburden was encountered near the Tay River (Praamsma, 2016).

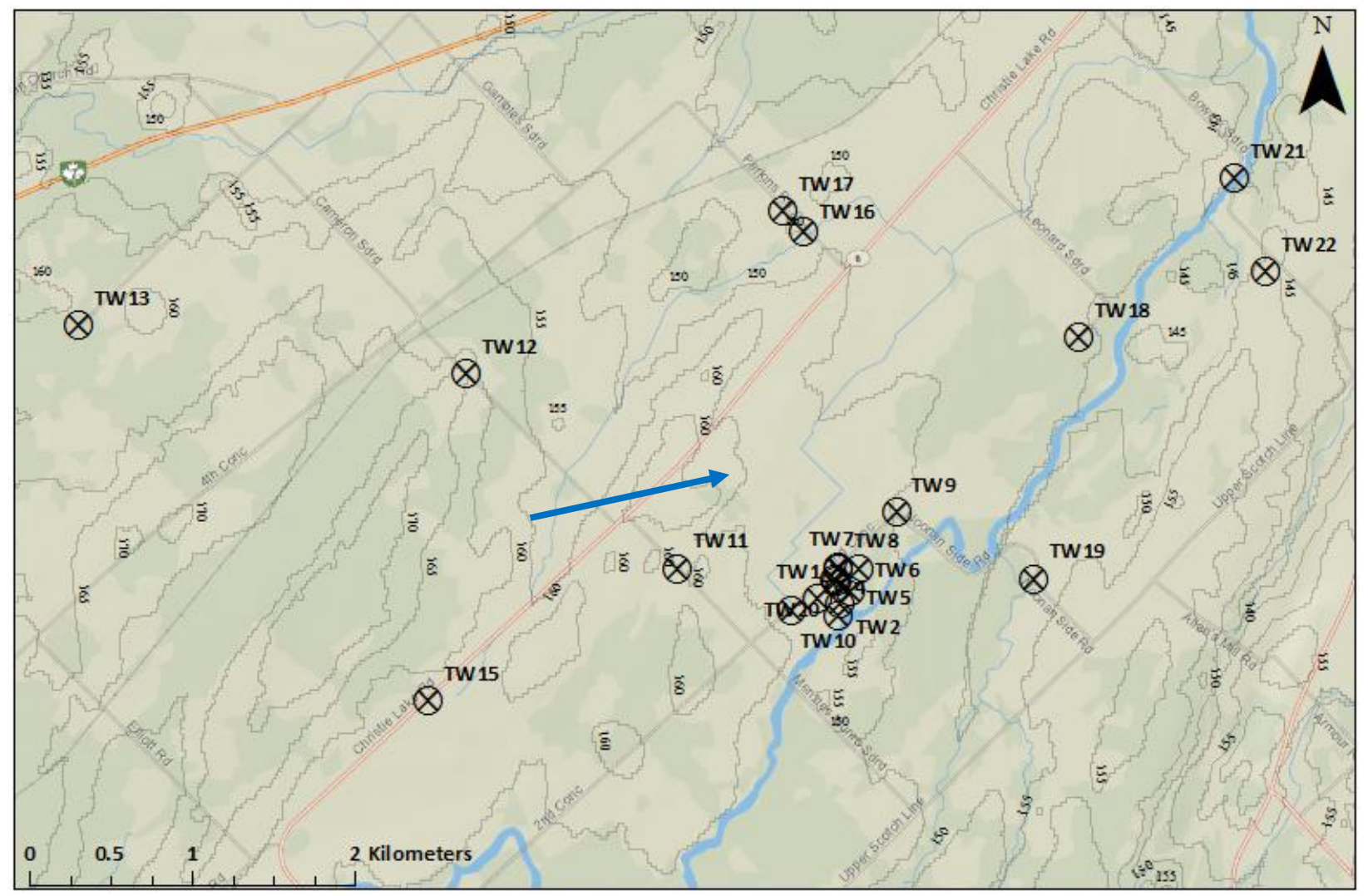

Figure 3.5: Location of 21 multi-level wells in Lanark County. Regional groundwater flow direction is eastward. Digital elevation data is displayed in units of meters above sea level and was obtained from Natural Resources Canada (2017). Regional groundwater flow (indicated by the blue arrow) was derived from April 2016 static water levels. 
Intensive agriculture is generally not practiced in the $865 \mathrm{~km}^{2}$ Tay River watershed approximately $22 \%$ of the watershed is farmed while $63 \%$ is forested (Milloy, 2007). Agricultural land is predominantly pasture for beef cattle, dairy cattle, horses, sheep, pigs, and turkeys. Typical crops in the regions include alfalfa, barley, corn, oats and soybeans. Within the confines of the research site, the largest agricultural farm has an area of $2 \mathrm{~km}^{2}$ and alternates between corn and soybean crops.

The Tay River Watershed is a tributary of the Rideau River system in the Great Lakes St. Lawrence drainage basin on the Canadian Shield (RVCA, 2002). Rural Tay Valley residents rely on groundwater for their potable water supply while the nearby town of Perth uses water from the Tay River (Milloy, 2007). The low-gradient Tay River flows over exposed, fractured bedrock or a thin veneer of coarse-grained sediments (Gleeson et al., 2009b).

Tile drainage exists on the hay field and is common throughout the study area (Gleeson et al., 2009b; Praamsma, 2016). Farmers generally install drainage piecemeal in areas of their fields where water pools. As a result of this patchy installation regime, there are incomplete records of tile drain locations within the hay field and broader study area. Fractures connected to the overburden near tile drains could act as an efficient path for contaminant transport to groundwater (Praamsma, 2016).

\subsubsection{Geology and Climate}

The Tay River Watershed is underlain by Precambrian and Paleozoic units (Wilson, 1961). The Precambrian syenite-migmatite gneiss is encountered as a banded gneissic rock; it is overlain by Ordovician-aged Nepean sandstone that only occurs at high elevations in the study area (Gleeson et al., 2009b; Wilson, 1961).

The aquifer is overlain by a thin, highly heterogeneous till veneer that generally has a low to medium-low permeability (Figure 3.6). Overburden layers range in depth between $0 \mathrm{~m}$ and $8 \mathrm{~m}$; they consist of organic deposits and unconsolidated glacial material (Kettles, 1992). The topography is hummocky and heterogeneous with complex surface water patterns due to its glacial history (Gleeson and Novakowski, 2009). Surface elevations near wells range from 143 to $168 \mathrm{mASL}$. Much of the heterogeneous surficial material is underlain by silty sand with a thickness greater than $1 \mathrm{~m}$ (Gleeson et al., 2009b). Outcrops are common throughout the study area. 


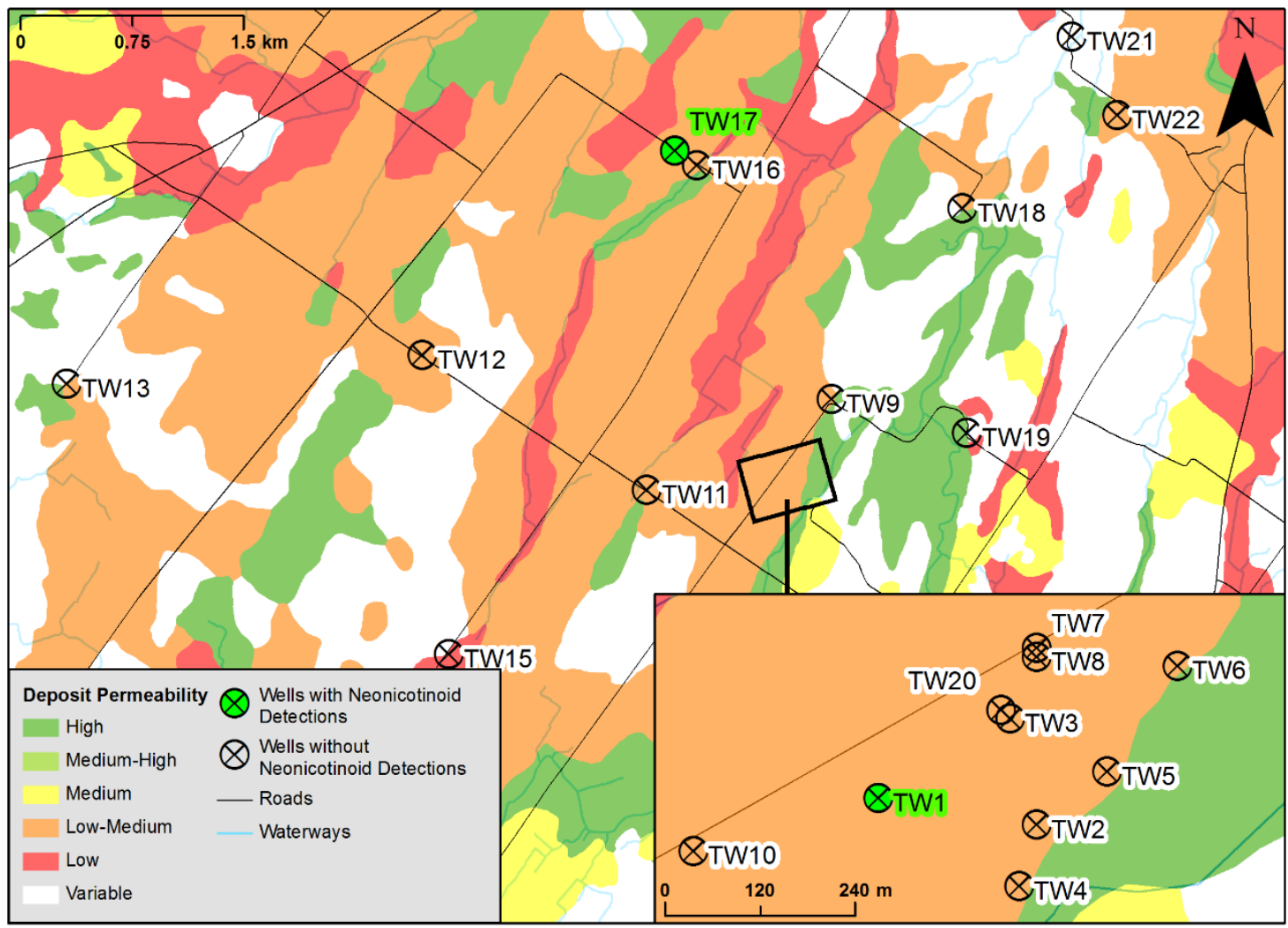

Figure 3.6: Relative permeability of the Lanark County study site (Ontario Geological Survey, 2010). Low to medium-low permeability overburden dominates the study region with deposits of variable permeability visible throughout.

Regional groundwater flow is towards the northeast (parallel to the Tay River) across the study site with an approximate gradient of 0.001 (Gleeson and Novakowski, 2009). Local variability in groundwater flow can occur due to seasonal variations in the hydraulic gradient and erratic fracture connectivity throughout the site (Levison et al., 2012). Groundwater levels are typically no more than $4 \mathrm{~m}$ below ground surface when recharge rates are low (Gleeson, 2009; Milloy, 2007; Praamsma et al., 2009). In the Tay River watershed, 93\% of private water wells are completed in the Precambrian bedrock (Golder Associates Ltd., 2003).

The climate in the Tay River watershed is humid temperate continental with cold winters and hot summers. Average monthly temperatures and precipitation between 1981 and 2010 range from $-9.8^{\circ} \mathrm{C}$ to $20.3^{\circ} \mathrm{C}$ and from $55.1 \mathrm{~mm}$ to $91.8 \mathrm{~mm}$ (Government of Canada, 2017). Evapotranspiration returns $60 \%$ of precipitation to the atmosphere, while runoff and infiltration account for $12 \%$ and $28 \%$ (Golder Associates Ltd., 2003).

\subsubsection{Previous Studies}

Research at the Lanark County field site began in 2004 when the first observation well was drilled (Milloy, 2007). The most recent well was drilled in 2008 - expanding the total number of 
observation wells to 21 (52 monitoring intervals). All studies that have been performed using these wells are summarized in Table 3.2.

Table 3.2: Summary of all studies performed using the Tay River wells in Lanark County

\begin{tabular}{|c|c|c|c|c|}
\hline Study Objectives & $\begin{array}{l}\text { Methodology } \\
\text { Highlights }\end{array}$ & Key Findings & $\begin{array}{l}\text { Field } \\
\text { Work } \\
\text { Dates }\end{array}$ & Source \\
\hline $\begin{array}{c}\text { - Investigate recharge } \\
\text { processes }\end{array}$ & $\begin{array}{l}\text { - Developed three } \\
\text { multilevel wells } \\
\text { - Slug tests using } \\
1.77 \text { m straddle } \\
\text { packer system }\end{array}$ & $\begin{array}{l}\text { - Long term barometric } \\
\text { efficiencies suggest an } \\
\text { unconfined aquifer } \\
\text { - Low recharge } \\
\text { correlates to minimal } \\
\text { aquifer storage } \\
\text { capacity }\end{array}$ & $\begin{array}{l}2004- \\
2005\end{array}$ & $\begin{array}{l}\text { Milloy } \\
\text { (2007) }\end{array}$ \\
\hline $\begin{array}{l}\text { - Provide a } \\
\text { comprehensive } \\
\text { conceptual model of } \\
\text { groundwater - surface } \\
\text { water interaction and } \\
\text { recharge in a gneissic } \\
\text { terrain at a local scale }\end{array}$ & $\begin{array}{l}\text { - Slug tests using } \\
\text { straddle packer } \\
\text { system } \\
\text { - Fracture } \\
\text { mapping and } \\
\text { electrical } \\
\text { conductivity } \\
\text { surveys } \\
\text { - Isotope } \\
\text { sampling }\end{array}$ & $\begin{array}{c}\text { - Groundwater flow in } \\
\text { upper } 30 \text { to } 40 \text { m of } \\
\text { bedrock is dominated by } \\
\text { a few horizontal fractures } \\
\text { that are weakly } \\
\text { connected by vertical } \\
\text { fractures } \\
\text { - Recharge does not } \\
\text { penetrate into deep } \\
\text { groundwater } \\
\text { - Groundwater likely } \\
\text { underflows Tay River at } \\
\text { hay field }\end{array}$ & $\begin{array}{l}2005- \\
2006\end{array}$ & $\begin{array}{l}\text { Praamsma } \\
\text { et al. (2009) }\end{array}$ \\
\hline $\begin{array}{l}\text { - Improve the } \\
\text { understanding } \\
\text { of biofilm growth and } \\
\text { biofouling on well } \\
\text { performance in a } \\
\text { fractured } \\
\text { rock aquifer }\end{array}$ & $\begin{array}{l}\text { - Grew biofilm in } \\
\text { new wells } \\
\text { - Slug tests using } \\
\text { straddle packer } \\
\text { system } \\
\text { - Downhole } \\
\text { videotaping } \\
\end{array}$ & $\begin{array}{c}\text { - Fractures with low } \\
\text { transmissivity are } \\
\text { susceptible to effects of } \\
\text { biofouling }\end{array}$ & 2006 & $\begin{array}{l}\text { Cooke } \\
(2007)\end{array}$ \\
\hline $\begin{array}{l}\text { - To determine if } \\
\text { lineaments are } \\
\text { hydraulic barriers to } \\
\text { groundwater recharge } \\
\text { and flow }\end{array}$ & $\begin{array}{l}\text { - Fracture } \\
\text { mapping } \\
\text { - Slug tests } \\
\text { - Numerical } \\
\text { simulations }\end{array}$ & $\begin{array}{l}\text { - Lineament areas are } \\
\text { barriers to recharge and } \\
\text { flow in this setting }\end{array}$ & 2006 & $\begin{array}{c}\text { Gleeson } \\
\text { and } \\
\text { Novakowski } \\
\text { (2009) }\end{array}$ \\
\hline
\end{tabular}




\begin{tabular}{|c|c|c|c|c|}
\hline $\begin{array}{l}\text { - Conduct a tracer } \\
\text { experiment to } \\
\text { investigate role of } \\
\text { overburden thickness } \\
\text { and effects of vertical } \\
\text { fracture connectivity } \\
\text { on contaminant } \\
\text { transport }\end{array}$ & $\begin{array}{c}\text { - infiltration tracer } \\
\text { experiment } \\
\text { - Loss on ignition } \\
\text { - Pumping tests } \\
\text { - Slug tests using } \\
\text { straddle } \\
\text { packer system } \\
\text { - Down-hole } \\
\text { videotaping } \\
\text { - Numerical } \\
\text { modelling }\end{array}$ & $\begin{array}{l}\text { - Solute transport from } \\
\text { ground surface to wells } \\
\text { through thin soil can be } \\
\text { rapid (on the order of } \\
\text { hours) } \\
\text { - Maximum } \\
\text { concentrations will not } \\
\text { necessarily be in the } \\
\text { shallow aquifer horizon }\end{array}$ & 2006 & $\begin{array}{c}\text { Levison and } \\
\text { Novakowski } \\
\text { (2012) }\end{array}$ \\
\hline $\begin{array}{l}\text { - Investigate whether } \\
\text { recharge is governed } \\
\text { by fracture networks } \\
\text { and/or overlying soil } \\
\text { characteristics }\end{array}$ & $\begin{array}{c}\text { - Isotope } \\
\text { sampling } \\
\text { - Numerical } \\
\text { simulation } \\
\text { - Slug tests } \\
\text { - Air-photo } \\
\text { interpretation, } \\
\text { seismic refraction } \\
\text { - Double-ring } \\
\text { infilitrometer }\end{array}$ & $\begin{array}{c}\text { - Rapid shallow recharge } \\
\text { from snowmelt occurs } \\
\text { near } \\
\text { thin layers of soil } \\
\text { - Soil thickness and } \\
\text { hydraulic conductivity are } \\
\text { key recharge parameters }\end{array}$ & $\begin{array}{l}2006- \\
2007\end{array}$ & $\begin{array}{l}\text { Gleeson et } \\
\text { al. (2009) }\end{array}$ \\
\hline $\begin{array}{l}\text { - To expand } \\
\text { knowledge on the } \\
\text { potential impact of } \\
\text { agricultural activities } \\
\text { on groundwater } \\
\text { quality in bedrock } \\
\text { aquifers }\end{array}$ & $\begin{array}{l}\text { - Pumping tests } \\
\text { - Slug tests using } \\
\text { straddle } \\
\text { packer system } \\
\text { - Down-hole } \\
\text { videotaping } \\
\text { - Groundwater } \\
\text { sampling }\end{array}$ & $\begin{array}{c}\text { - Recharge influences } \\
\text { contaminant transport in } \\
\text { this setting } \\
\text { - Periodic upgradient } \\
\text { sources, dilution from } \\
\text { recharge, and } \\
\text { heterogeneous flow } \\
\text { systems lead to } \\
\text { unpredictable } \\
\text { contaminant } \\
\text { concentrations in } \\
\text { bedrock aquifers with } \\
\text { minimal overburden }\end{array}$ & $\begin{array}{l}2006- \\
2007\end{array}$ & $\begin{array}{c}\text { Levison and } \\
\text { Novakowski } \\
\text { (2009) }\end{array}$ \\
\hline $\begin{array}{l}\text { - To investigate the } \\
\text { potential of PBDE } \\
\text { contamination }\end{array}$ & $\begin{array}{l}\text { - Pumping tests } \\
\text { - Slug tests using } \\
\text { straddle packer } \\
\text { system } \\
\text { - Down-hole } \\
\text { videotaping } \\
\text { - Groundwater } \\
\text { sampling }\end{array}$ & $\begin{array}{l}\text { - The complex } \\
\text { hydrogeological setting } \\
\text { and variable sources can } \\
\text { lead to unpredictable } \\
\text { PBDE groundwater } \\
\text { concentrations }\end{array}$ & $\begin{array}{l}2006- \\
2007\end{array}$ & $\begin{array}{l}\text { Levison et } \\
\text { al. (2012) }\end{array}$ \\
\hline
\end{tabular}




\begin{tabular}{|c|c|c|c|c|}
\hline $\begin{array}{l}\text { - To evaluate the } \\
\text { pattern and rate of } \\
\text { groundwater } \\
\text { discharge in a } \\
\text { fractured bedrock } \\
\text { aquifer using novel } \\
\text { and standard } \\
\text { methods }\end{array}$ & $\begin{array}{l}\text { - Measurement of } \\
\text { natural, } \\
\text { radioactive, and } \\
\text { thermal tracers } \\
\text { - Streamflow } \\
\text { measurements } \\
\text { - Steady-state } \\
\text { advective model }\end{array}$ & $\begin{array}{l}\text { - Groundwater and } \\
\text { surface water can be } \\
\text { largely decoupled in this } \\
\text { watershed } \\
\text { - Groundwater discharge } \\
\text { is distributed regionally } \\
\text { across the watershed }\end{array}$ & $\begin{array}{l}2006- \\
2008\end{array}$ & $\begin{array}{l}\text { (Gleeson et } \\
\text { al., 2009a) }\end{array}$ \\
\hline $\begin{array}{l}\text { - Explore the } \\
\text { occurrence } \\
\text { rate and transport } \\
\text { mechanisms of } \\
\text { human viruses in } \\
\text { fractured rock aquifers }\end{array}$ & $\begin{array}{l}\text { - Field survey } \\
\text { - Viral infiltration } \\
\text { (tracer) } \\
\text { experiment }\end{array}$ & $\begin{array}{l}\text { - Viral contamination } \\
\text { poses a threat to } \\
\text { fractured rock } \\
\text { groundwater in rural } \\
\text { areas where onsite } \\
\text { septic tanks exist } \\
\text { - Current monitoring } \\
\text { practices may be } \\
\text { inadequate to prevent } \\
\text { exposure to human } \\
\text { viruses }\end{array}$ & $\begin{array}{l}2008- \\
2009\end{array}$ & $\begin{array}{l}\text { Trimper } \\
(2010)\end{array}$ \\
\hline $\begin{array}{l}\text { - Explore the } \\
\text { mechanisms behind } \\
\text { rapid response in } \\
\text { hydraulic head in } \\
\text { shallow fractured rock } \\
\text { at the scale of an } \\
\text { outcrop }\end{array}$ & $\begin{array}{c}\text { - Slug tests using } \\
\text { straddle packer } \\
\text { system } \\
\text { - Down-hole } \\
\text { videotaping } \\
\text { - Ground } \\
\text { penetrating radar } \\
\text { survey } \\
\text { - Guelph } \\
\text { permeameter } \\
\text { tests } \\
\text { - Numerical } \\
\text { modelling }\end{array}$ & $\begin{array}{l}\text { - A small amount }(0.4 \mathrm{~m}) \\
\text { of drift material can } \\
\text { completely eliminate } \\
\text { response in well } \\
\text { - High ET, low specific } \\
\text { yield of the rock, and } \\
\text { outcropping results in } \\
\text { localized rapid recharge } \\
\text { events at this site }\end{array}$ & 2012 & $\begin{array}{c}\text { Miles and } \\
\text { Novakowski } \\
(2016)\end{array}$ \\
\hline $\begin{array}{c}\text { - Explore flow, } \\
\text { recharge, } \\
\text { and transport } \\
\text { dynamics in fractured } \\
\text { rock aquifers with low- } \\
\text { lying outcrops }\end{array}$ & $\begin{array}{l}\text { - Regional } \\
\text { groundwater } \\
\text { quality study } \\
\text { - Infiltration } \\
\text { experiment } \\
\text { - Numerical } \\
\text { modelling }\end{array}$ & $\begin{array}{l}\text { - Overburden hinders } \\
\text { transport to fractures } \\
\text { - High groundwater } \\
\text { velocities occur in large } \\
\text { fractures } \\
\text { - High fracture gradients } \\
\text { dilute tracer } \\
\text { concentrations }\end{array}$ & 2007 & $\begin{array}{c}\text { Praamsma } \\
\text { (2016) }\end{array}$ \\
\hline
\end{tabular}

Within the Lanark County research site, groundwater flow in the upper 30-40 m of bedrock in the region is likely dominated by horizontal fractures that are connected by sporadic and dispersed vertical fractures (Praamsma et al., 2009). High gradients can be found in surface water bodies in the region - this further suggests poor subsurface connectivity (Gleeson and Novakowski, 2009). Regionally, the groundwater generally follows the Tay River eastward while topographic 
highs at TW11, TW12, and TW13 exemplify the local, heterogonous nature of the fracture rock aquifer.

Poor subsurface connectivity is again demonstrated through the small number of wells that show discernable hydraulic connectivity. Wells TW3 and TW20 (8 m apart), along with TW7 and TW8 (12 $\mathrm{m}$ apart) are the only two pairs of wells that show clear signs of a hydraulic connection (Praamsma, 2016). Wells TW3, TW20 and TW8 demonstrate connections to the surface (Gleeson et al., 2009b; Levison and Novakowski, 2012; Praamsma et al., 2009); wells TW4 and TW21 exhibit connections to the Tay River (Praamsma et al., 2009).

Despite high water quality throughout the year, contaminant transport can occur quickly in this watershed - especially in areas with negligible overburden (Praamsma, 2016). Nitrate studies and tracer experiments have found that contamination can occur at depths up to $30 \mathrm{mBGS}$ in wells TW3D, TW1D, and TW17. Significant nitrate levels occur downgradient of pasture lands at TW1, TW3, and TW10 (Levison and Novakowski, 2009; Praamsma, 2016). E. coli has been detected at 10 well intervals throughout the study site (TW3S, TW6M, TW7S, TW7D, TW8, TW12D, TW16D, TW19S, TW21D, TW22S). Concentrations of $E$. coli have been linked to increased precipitation events in the autumn months (Levison and Novakowski, 2009; Praamsma, 2016). 


\subsection{References}

AquaResource Inc., 2009. Long Point Region , Kettle Creek and Catfish Creek Integrated Water Budget.

Armstrong, T.R., Carter, D.K., 2010. The subsurface Paleozoic stratigraphy of southern Ontario.

Cooke, B.E., 2007. Investigation of the Effects of Biofouling on the Hydraulic Properties of Wells in Fractured.

Gardner, S.G., 2017. Groundwater Nitrate in Three Hydrogeologic Settings throughout Southwestern Ontario. University of Guelph.

Gleeson, T., Novakowski, K., 2009. Identifying watershed-scale barriers to groundwater flow: Lineaments in the Canadian shield. Bull. Geol. Soc. Am. 121, 333-347. doi:10.1130/B26241.1

Gleeson, T., Novakowski, K., Cook, P.G., Kyser, T.K., 2009a. Constraining groundwater discharge in a large watershed: Integrated isotopic, hydraulic, and thermal data from the Canadian shield. Water Resour. Res. 45. doi:10.1029/2008WR007622

Gleeson, T., Novakowski, K., Kurt Kyser, T., 2009b. Extremely rapid and localized recharge to a fractured rock aquifer. J. Hydrol. 376, 496-509. doi:10.1016/j.jhydrol.2009.07.056

Gleeson, T.P., 2009. Groundwater recharge, flow and discharge in a large crystalline watershed 268.

Golder Associates Ltd., 2003. Renfrew County-Mississippi-Rideau Groundwater Study. Ottawa, ON.

Government of Canada, 2017. Canadian Climate Normals [WWW Document]. URL http://climate.weather.gc.ca/climate_normals/index_e.html (accessed 5.23.17).

Hollingham, M., 2011. Sources of elevated nitrate concentrations in municipal groundwater supplies in Norfolk and Oxford Counties. University of Waterloo.

Kettles, I.M., 1992. Surficial Geology, A Series Map, Report 1800A. Perth, ON.

Levison, J., Novakowski, K., 2009. The impact of cattle pasturing on groundwater quality in bedrock aquifers having minimal overburden. Hydrogeol. J. 17, 559-569. doi:10.1007/s10040008-0385-z 
Levison, J., Novakowski, K., Reiner, E.J., Kolic, T., 2012. Potential of groundwater contamination by polybrominated diphenyl ethers (PBDEs) in a sensitive bedrock aquifer (Canada). Hydrogeol. J. 20, 401-412. doi:10.1007/s10040-011-0813-3

Levison, J.K., Novakowski, K.S., 2012. Rapid transport from the surface to wells in fractured rock: A unique infiltration tracer experiment. J. Contam. Hydrol. 131, 29-38. doi:10.1016/j.jconhyd.2012.01.001

LPRCA, 2008. Long Point Region Watershed Characterization Report. Toronto.

Macdonald, G.D., 2015. Developing Novel Techniques for Measuring In Situ Groundwater Nitrate Concentrations, Vertical Geochemical Profiling , and Real-time Remote Groundwater Quality Monitoring. University of Guelph.

Marich, A.S., 2010. An Assessment of Subsurface Sediments in the Central Norfolk Sand Plain; Norfolk and Oxford Counties, Southern Ontario, Groundwater Resources Study 14. Ontario Geological Survey.

Matrix Solutions Inc., 2015. Long Point Region Tier Three Water Budget and Local Area Risk Assessment. Waterloo.

Matrix Solutions Inc., 2014. Long Point Region Tier Three Water Budget and Local Area Risk Assessment Appendix B: Model Development and Calibration Report. Waterloo.

Matrix Solutions Inc., 2013. Long Point Region Tier Three Water Budget and Local Area Risk Assessment Appendix A: Physical Characterization Report. Waterloo.

Miles, O.W., Novakowski, K.S., 2016. Large water-table response to rainfall in a shallow bedrock aquifer having minimal overburden cover. J. Hydrol. 541, 1316-1328. doi:10.1016/j.jhydrol.2016.08.034

Milloy, C.A., 2007. Measurement of Hydraulic Head for the Evaluation fo Groundwater Recharge to Discrete Fracture Zones in a Crystalline Bedrock Aquifer. Queen's University. Natural Resources Canada, 2017. Canadian Digital Elevation Model Mosaic. Ottawa, ON. Ontario Geological Survey, 2010. Surficial Geology of Southern Ontario.

Praamsma, T., Novakowski, K., Kyser, K., Hall, K., 2009. Using stable isotopes and hydraulic head data to investigate groundwater recharge and discharge in a fractured rock aquifer. J. Hydrol. 366, 35-45. doi:10.1016/j.jhydrol.2008.12.011 
Praamsma, T.W., 2016. Rock Outcrops in the Canadian Shield: An Investigation of Contaminant Transport from Surface Sources in Fractured Rock Aquifers. Queen's University.

RVCA, 2002. Tay River Watershed Management Plan. Manotick.

Saleem, S.R., Levison, J., Parker, B., Martin, R.C., 2016. Development of a Field-Scale Model to Simulate Nitrate Transport in Groundwater from Agricultural Lands, in: The Geological Society of America Joint 52nd Northeastern Annual Section. Pittsburgh.

Trimper, S.A., 2010. The Presence and Transport of Human Enteric Viruses in Fractured Bedrock Aquifers. Queen's University.

Wilson, M.E., 1961. Geology of Perth-Lanark and Leeds counties, Ontario. Map 1089 A. Ottawa, ON. 


\section{Neonicotinoids in Groundwater: Presence and Fate in Two Distinct Hydrogeologic Settings in Ontario, Canada}

\subsection{Abstract}

Neonicotinoids are a group of insecticides that are commonly used in agriculture throughout the world. Despite their widespread use, there are significant knowledge gaps related to the presence and fate of neonicotinoids in groundwater. This research consists of a seasonal groundwater sampling regime, soil sampling, a crop survey, and mathematical modelling exercises which aim to test the environmental parameters governing the transport of clothianidin, imidacloprid, and thiamethoxam to groundwater in two distinct hydrogeologic settings. Both of these research sites are located in Ontario, Canada: one comprises an unconfined, sandy quaternary aquifer while the other consists of a fractured, crystalline bedrock aquifer (Canadian Shield) under a thin layer of overburden. Groundwater sampling was conducted using between 18 and 26 monitoring intervals at each research site in April 2016, July 2016, August 2016, November 2016, and April 2017. All laboratory analysis was conducted using the LC-ESI(+)-MS/MS at the University of Guelph Ridgetown Campus. Results from groundwater sampling found the neonicotinoids clothianidin, imidacloprid, and thiamethoxam with maximum concentrations and detection frequencies above the level of quantitation of $2.09 \mu \mathrm{g} / \mathrm{L}, 0.7 \mu \mathrm{g} / \mathrm{L}, 0.46 \mu \mathrm{g} / \mathrm{L}$, and $2.2 \%, 0.9 \%, 1.3 \%$, respectively. Clothianidin peaked at four monitoring intervals in August 2016 (approximately three months after seed sowing and two months prior to harvesting). Imidacloprid was found at low concentrations that were marginally above the level of quantitation during July and August sampling. Thiamethoxam was found at one monitoring interval in Lanark County during both spring freshet (April) sampling rounds. Mathematical modelling revealed that under similar environmental conditions, clothianidin and thiamethoxam are released in a similar pattern that resembles a pulse. The delayed release of thiamethoxam to one monitoring interval in Lanark County was likely due to unusually low permeability overburden near the well. In both of these hydrogeologic settings, modelling revealed that the transport of both clothianidin and thiamethoxam is dominated by processes in the vadose zone. Future research into this subject should focus on how neonicotinoids behave within different climatic and hydrogeologic settings outside of Ontario, Canada. 


\subsection{Introduction}

Neonicotinoids are a group of insecticides that are commonly used on crops such as potato, wheat, maize, and soybeans. These insecticides have become prevalent largely due to their ease of application; they are most often applied as a seed dressing prior to purchasing by farmers. The first neonicotinoid, imidacloprid, was introduced in 1991, followed in the mid-1990s by the other first generation neonicotinoids: acetamiprid, nitenpyram, and thiacloprid (Maienfisch et al., 2001). Clothianidin and thiamethoxam are second generation neonicotinoids, while the third generation only includes dinotefuran. Each neonicotinoid generation has a unique chemical composition; these insecticides are grouped together due to their mode of action on target insects (Sheets, 2010).

In the late 2000s, neonicotinoids began to come under global scrutiny due to contentious links between their use and the potentially associated decline of both aquatic invertebrate and pollinator populations (Canadian Council of Ministers of the Environment, 2007; Girolami et al., 2009; Godfray et al., 2014; Goulson, 2013; Miranda et al., 2011; Morrissey et al., 2015; Woodcock et al., 2017). Such scrutiny has led to controversial restrictions and bans on neonicotinoid use in the European Union and Canada (Godfray et al., 2014). International regulations target the three most popular neonicotinoids: clothianidin, imidacloprid, and thiamethoxam (European Commission, 2013; Government of Ontario, 2009; PMRA, 2016a). In Ontario, Canada, legislation stipulates certain actions with the target of an $80 \%$ reduction (compared to 2015 levels) of the number of acres planted with neonicotinoid-treated maize and soybean crops by 2017 (Government of Ontario, 2009). Despite this legislation, the presence and fate of neonicotinoids in Ontario water resources has not been comprehensively researched (Chapter 2 - Literature Review)

Typically less than $10 \%$ of the active ingredient in neonicotinoid seed treatments is absorbed by the target crop-the remainder degrades or enters the environment (Goulson, 2014). All neonicotinoids are either moderately or highly soluble and can be broken down in an order of hours through aqueous photolysis (Bonmatin et al., 2015; Fossen, 2006; Morrissey et al., 2015). All neonicotinoids have low octanol-water coefficients $\left(\mathrm{K}_{\mathrm{oc}}\right)$; this suggests a low likelihood of absorbing to organic carbon in soil and therefore a potential to leach into the groundwater supply (Bonmatin et al., 2015; Hladik et al., 2014; Morrissey et al., 2015). Most research about neonicotinoids in the natural environment has focused on their presence in and transport to soil, dust, and surface water (Chapter 2 - Literature Review). 
Imidacloprid, the first neonicotinoid, can remain in soil with a low water content, high $\mathrm{pH}$, high organic matter, and high mineral clay content (Bonmatin et al., 2015; Fossen, 2006; Goulson, 2013). In groundwater, imidacloprid concentrations can peak during and after seed sowing or in the early stages of plant growth (Bortoluzzi et al., 2007; Department of Environmental Conservation, 2014). Imidacloprid has been detected in basaltic rock aquifers underlying clayey soils in southern Brazil and unspecified aquifers underlying sandy, permeable soils in northern Québec, Canada, at concentrations up to $6.22 \mu \mathrm{g} / \mathrm{L}$ and $6.4 \mu \mathrm{g} / \mathrm{L}$, respectively (Bortoluzzi et al., 2007; Giroux, 2003). Clothianidin and thiamethoxam are more persistent in silty soil than sandy soil (Schaafsma et al., 2016), while thiamethoxam can be immobile under dry soil conditions (Bonmatin et al., 2015). Thiamethoxam has been detected most frequently in groundwater during the fall and winter months (Giroux and Sarrasin, 2011). The highest reported clothianidin and thiamethoxam concentrations occurred in unspecified aquifers underlying well-drained, sandy soils in Wisconsin, USA, at respective concentrations of $3.33 \mu \mathrm{g} / \mathrm{L}$ and $8.93 \mu \mathrm{g} / \mathrm{L}$ (Huseth and Groves, 2014).

Recent research has found that the physical properties of neonicotinoids, along with their observed behavior in soil and surface water, justify further study into their presence in groundwater (Anderson et al., 2015; Bacey, 2000; Fossen, 2006; Goulson, 2013; Gupta et al., 2002; Hladik et al., 2014; Kurwadkar et al., 2013; PMRA, 2016a). There are substantial knowledge gaps regarding the presence and fate of neonicotinoids in groundwater - existing research often omits pertinent information such as land use, land-rate application, and the type of soil and aquifer (Bergin and Nordmark, 2009; Bortoluzzi et al., 2007; Browne et al., 2017; Department of Environmental Conservation, 2014; Felsot, 2001; Giroux, 2014; Giroux and Sarrasin, 2011; Huseth and Groves, 2014; Lamers et al., 2011; Weaver and Nordmark, 2004). Typically, previous research has simply summarized the findings from monitoring programs and has not proposed theories for transport mechanisms to groundwater. It is necessary to evaluate these environmental parameters in order to make predictions and assess risk for the current and future uses of neonicotinoids.

Given the inconsistent nature of studies on neonicotinoids in groundwater and the uncertainties around their transport mechanisms in the subsurface, there is justification for further detailed research regarding the presence and fate of these popular insecticides in different hydrogeological settings. Thus, the purpose of this research is to quantify the presence and fate of clothianidin, imidacloprid, and thiamethoxam in two distinct aquifers located in Ontario, Canada: the sandy, unconfined aquifer in Norfolk County and the fractured, crystalline bedrock aquifer of 
Lanark County. This research includes a seasonal groundwater sampling regime conducted over one year as well as subsequent mathematical modelling to examine the factors that influence the movement of neonicotinoids to the water table and subsequently in the underlying groundwater setting.

\subsection{Materials and Methods}

This research is comprised of an extensive site assessment, a monitoring well and soil sampling program, an analytical program for detecting contaminants, crop surveys, and mathematical modelling exercises. These methods are described in the following section.

\subsubsection{Field Sites}

Research was conducted at two field sites within Ontario, Canada-Norfolk County and Lanark County (Figure 4.1). Norfolk County is an agricultural-intensive region with approximately $78 \%$ of the land actively cultivated (LPRCA, 2008), while neonicotinoid-treated maize, soybean, and wheat crops are common in the region (Agriculture and Agri-Food Canada, 2017; OMAFRA, 2016). It was predicted that Norfolk County would have a high probability of neonicotinoid contamination in groundwater due to the intense use of these crops and a regional history of agricultural contaminants in groundwater (Gardner, 2017; Hollingham, 2011; Macdonald, 2015; Saleem et al., 2016). Intensive agriculture is generally not practiced in Lanark County; within the extents of the research site in 2016, only $29 \%$ of the land was cultivated (Agriculture and AgriFood Canada, 2017). However, past research has found that the groundwater in Lanark County can still be vulnerable to agricultural and other land-applied contaminants (Levison et al., 2012; Levison and Novakowski, 2009; Praamsma, 2016; Trimper, 2010). Due to the presence of small-scale maize and soybean fields in the region (Agriculture and Agri-Food Canada, 2017), it was predicted that neonicotinoids could be detected in the monitoring wells with a history of agricultural contamination. 


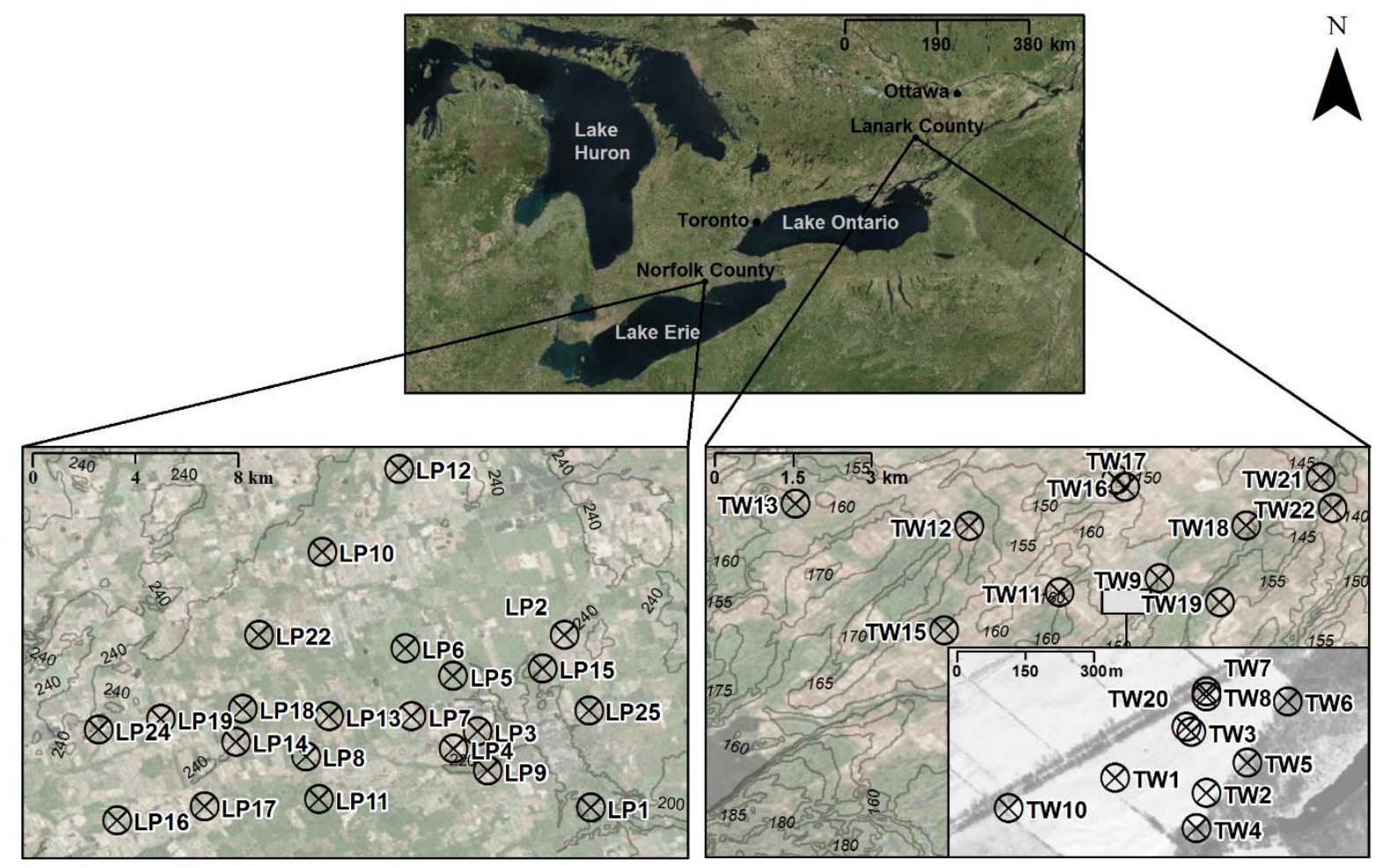

Figure 4.1: The location of each research site in southern Ontario, Canada (upper image). Norfolk County, bottom left, is shown with monitoring wells that are referenced as 'LP'. LP20, LP21, LP23, and LP26 reside west of the domain and were not included in this study. The Lanark County research site, bottom right, is shown with the well cluster in a hay field enlarged in the bottom right corner. All wells in Lanark County are referenced as 'TW'. The elevation is contoured in metres above sea level at both research sites.

The soils at the Norfolk County study site are predominantly highly permeable, coarse-grained sand with some fine-grained areas (Chapman and Putnam, 1984). Norfolk County quaternary geology consists of the Horseshoe Moraine and Mount Elgin, the Norfolk Sand Plain, and the Haldimand Sand Plain (Armstrong and Carter, 2010). Within the confines of the research site, the Norfolk Sand Plain dominates. This low-relief plain is composed of silty sand and gravel sediments that are up to $27 \mathrm{~m}$ thick (LPRCA, 2008). All monitoring wells used in this research were drilled into the quaternary aquifer above the bedrock. Using slug tests and pumping tests, the hydraulic conductivity values within the Norfolk Sand Plain were calculated to range from $1.8 \times 10^{-8}$ to $1.7 \times 10^{-3} \mathrm{~m} / \mathrm{s}$ (Matrix Solutions Inc., 2014). The Lanark County aquifer is overlain by a thin to non-existent, low-permeability till veneer (outcrops are common throughout the study area). Overburden layers consist of organic deposits and unconsolidated glacial material (Kettles, 1992). The topography is hummocky and heterogeneous with complex surface water patterns 
due to its glacial history (Gleeson and Novakowski, 2009). Double-ring infiltrometer experiments that were completed on the hay field with the well cluster determined a shallow vertical hydraulic conductivity within the range of $4.8 \times 10^{-7}$ to $3.6 \times 10^{-6} \mathrm{~m} / \mathrm{s}$ (Gleeson et al., 2009a). The Tay River Watershed is underlain by Precambrian and Paleozoic units (Wilson, 1961). The Precambrian syenite-migmatite is encountered as a banded gneissic rock; it is overlain by an isolated Ordovician-aged Nepean sandstone that only occurs at high elevations in the study area (Gleeson et al., 2009b; Wilson, 1961). The formation at the location of the monitoring wells at this research site has a transmissivity range between $1.00 \times 10^{-10}$ to $3.73 \times 10^{-2} \mathrm{~m}^{2} / \mathrm{s}$ for a $1.77 \mathrm{~m}$ packer interval (Praamsma, 2016).

One set of 26 multi-level wells (58 clustered monitoring intervals) is located in Norfolk County. They are located predominately between the population centres of Delhi and Simcoe within a 140,000 ha extent. All of these monitoring wells in Norfolk County are $85 \mathrm{~mm}$ in diameter and were drilled for the Long Point Tier Three Water Budget Study using track mounted drill rigs between September of 2010 and January of 2011 (Matrix Solutions Inc., 2015). Grout, holeplugs (bentonite), and \#2 silica sand were used to isolate each screened interval (2.8 to $51.1 \mathrm{mBGS}$ ) (Appendix A - Well Data). Monitoring wells at the Lanark County field site were drilled progressively for research (Queen's University) between 2004 and 2008 (Milloy, 2007; Praamsma, 2016). These 21 multi-level wells (52 nested monitoring intervals) are located within a 3400 ha area in the Tay River Watershed (a tributary of the Rideau river system), with ten of the wells clustered in a 10 ha hay field. All of the Lanark County wells are $0.15 \mathrm{~m}$ in diameter and were drilled with an air rotary rig (Milloy, 2007; Praamsma, 2016). Casing was installed into the upper $0.5 \mathrm{~m}$ of competent bedrock. Four wells were left open with no distinct monitoring intervals while the remainder were completed using either two or three $0.05 \mathrm{~m}$ diameter PVC pipes. These multi-level piezometers were completed with bentonite and \#2 sand emplaced to isolate each screened interval (3.6 to 56.0 mBGS) (Appendix A - Well Data).

The monitoring wells in Norfolk County and Lanark County are hereafter referenced as Long Point Monitoring Wells ("LP-MW") and Tay Wells ("TW"), respectively. Well labels are typically followed by the letters "S", "M", and "D", which refers to shallow, mid, and deep intervals, respectively. When no label is attached, it connotes an open well that resembles a domestic well.

\subsubsection{Field Sampling Regime}

Five groundwater sampling rounds were conducted at both research sites between 2016 and 2017 (April 2016, July 2016, August 2016, November 2016, and April 2017). The April sampling occurred during the spring freshet, the July and August sampling took place between seed sowing 
and crop harvesting, while the November sampling occurred during maize and soybean crop harvest. Soil samples were collected at both research sites in July 2016 to link surficial neonicotinoid concentrations to those measured in the groundwater.

Between 18 and 26 monitoring intervals were sampled at each site per sampling round (Appendix B - Raw Sampling Data). These intervals were chosen out of the 110 available monitoring intervals based on: surrounding land use; past history of vulnerability to surface-applied contaminants; variations in depth; and well accessibility. All wells were purged using a submersible groundwater pump (either a Grundfos Redi-Flow 2, a GeoSub SS pump, or a Monsoon SS pump). Purge water was pumped through a flow cell while a calibrated YSI 556 handheld instrument measured temperature, dissolved oxygen, electrical conductivity, and oxidation-reduction potential (ORP). These field parameters were recorded upon stabilization, which typically occurred after a 15 to 25 -minute purge. At that point, nitrate- $\mathrm{N}$ readings were recorded on site using a Satlantic SUNA V2 (Satlantic, 2017) with the procedure described in Macdonald (2015). Samples were collected in clean $1 \mathrm{~L}$ amber glass bottles and placed in a new plastic freezer bag. The bottle cleaning procedure was determined through rinsing each bottle with deionized water (Fernbrook Springs Water, Amaranth, Ontario, Canada) until neonicotinoid residues were not detected. It was determined that rinsing each bottle three times with deionized water was sufficient for removing neonicotinoid residue. Each bottle and bottle cap was rinsed with well water three times before the sample was taken. Efforts were made to eliminate cross-contamination of samples by wearing disposable nitrile gloves while each bottle was handled, and by shielding each sample from wind and sunlight during the collection of groundwater. The samples were chilled in darkness in the field (using ice packs and a cooler) and then frozen upon return to the laboratory each night. The samples remained frozen until laboratory analysis.

Due to the low concentrations at which neonicotinoids occur in groundwater, triplicate samples were taken during the first sampling round (April 2016) to verify field and laboratory QA/QC practices. One set of field blanks and equipment blanks was also taken.

The Tay River was also sampled adjacent to TW4 and TW21 in August 2016 in order to assess possible connections between river and groundwater contamination. These two samples were collected from the centre of the river. The bottle was rinsed three times with river water and the sample was taken from mid-depth. The samples were stored and analyzed with the same procedure used for all groundwater samples. 
Soil sampling was conducted around wells near agricultural fields that have a history of groundwater contamination (Appendix F - Soil Sampling Locations). Near each of these wells, four auger cores were taken to a depth of $15 \mathrm{~cm}$ in upgradient easement ditches. Seventeen soil samples were taken using the methods developed by Schaafsma et al. (2015) which involved mixing each of the four cores into a single sample within a black garbage bag, chilling the sample in darkness until the end of each day when it was placed in a freezer and frozen. Samples were thawed overnight at room temperature in darkness before laboratory analysis. Soil sampling was conducted at the well cluster in Lanark County through taking four auger cores on and upgradient of the hay field. These four cores were combined and analyzed as one sample. Prior to the collection of each soil sample, the auger was cleaned with Spray Nine® Heavy Duty Cleaner, scrubbed, and rinsed with bottled water to reduce the likelihood of cross-contamination. New, disposal nitrile gloves were used for each soil sample.

Groundwater elevations were also monitored at several wells using barometrically-compensated pressure transducers (Solinst Canada Ltd., 2015). These water levels were verified by manually measuring static water levels in the monitoring wells during each sampling round. Local precipitation was recorded using on site rain gauges and local Environment and Climate Change Canada weather stations (Environment and Climate Change Canada, 2017; Hoskin Scientific, 2017). The Delhi CS weather station was used to gather all precipitation data for the Norfolk County research site (it is located approximately $5 \mathrm{~km}$ northwest of Delhi, Ontario). A rain gauge was installed in the hay field at the Lanark County research site in July 2016 and used to gather precipitation data until April 2017. Prior to the installation of this rain gauge, the Drummond Centre weather station (located $24 \mathrm{~km}$ northeast of the hay field) was used to acquire precipitation data for Lanark County.

Samples were also taken from five domestic farm wells in the area of Ridgetown, Ontario, in January 2016. The sampling point for each well was the faucet closest to the pump before any treatment and before the pressure tank. Prior to any sampling, the faucet was rinsed with clean tap water and run for five minutes to purge the line and faucet bib. While the pump was running, $500 \mathrm{~mL}$ of water was collected in a new, screw-top, amber glass sampling bottle. The samples were kept chilled and dark until analysis.

\subsubsection{Laboratory Analysis Procedure}

All samples were analyzed for six neonicotinoid insecticides (acetamiprid, clothianidin, dinotefuran, imidacloprid, thiacloprid, and thiamethoxam), one ryanoid insecticide (cyantraniliprole), two herbicides (atrazine, metolachlor), and two fungicides (azoxystrobin, 
mefenoxam) using a liquid chromatography-positive electrospray ionization-mass spectrometery tandem-mass spectrometry system (LC-ESI(+)-MS/MS) (Schaafsma et al., 2017).

Frozen water samples were thawed overnight in darkness at room temperature before extraction. Each sample was extracted in triplicates in order to assess the random injection error. Initially, $10 \mathrm{ml}$ aliquots were transferred into a $50 \mathrm{ml}$ centrifuge tube containing $20 \mathrm{ml}$ of acetonitrile. After that, the solution was vortexed for $1 \mathrm{~min}$ and mixed with $4 \mathrm{~g}$ of anhydrous magnesium sulfate, $1 \mathrm{~g}$ of sodium chloride, $1 \mathrm{~g}$ of sodium citrate tribasic and $0.5 \mathrm{~g}$ of sodium hydrogencitrate sesquihydrate. Water subsamples were then hand-shaken for one-minute and centrifuged at $3000 \mathrm{rpm}$ for five-minutes. The resulting acetonitrile supernatant $(4 \mathrm{ml})$ was transferred to a $5 \mathrm{~mL}$ test tube and mixed with $20 \mu \mathrm{L}$ of $100 \mathrm{ng} / \mathrm{ml}$ internal standard stock solution that was prepared in acetonitrile. The $5 \mathrm{~mL}$ test tube was then placed under a nitrogen stream (Nitrovap Generator, Parker Balston, Haverhill, MA, USA) at $40^{\circ} \mathrm{C}$ and evaporated to dryness. Subsamples were then reconstituted in the dilution solvent (1:1 methanol/water (v/v) containing $5 \mathrm{mM}$ formic acid), vortexed for 2 mins, and transferred into a $2 \mathrm{~mL}$ amber glass auto-sampler vial. This was followed by random injection sequences (50 $\mu \mathrm{L}$ aliquot) into an Agilent 1100 Series HPLC (Agilent Technologies, Santa Clara, CA, USA). The HPLC was equipped with a $150 \mathrm{~mm}$ Gemini C18 reverse phase column (Phenomenex, Torrance, CA) coupled with an lonics EP 10+ modified API triple quadruple mass spectrometer ( $A B$ SCIEX, Concord, ON) system using a positive electrospray ionization.

Optimal LC-ESI(+)-MS/MS parameters for each analyte and relevant deuterium-labeled internal standard were determined through manual tuning (10 $\mathrm{ng} / \mu \mathrm{L}$ solutions in dilution solvent) using the multiple reaction monitoring procedure reported in detail by Schaafsma et al. (2017). Results of the optimized mass spectrometry parameters used in this study are summarized in Appendix G - Lab Analysis Information. Clothianidin, thiamethoxam, imidacloprid, acetamiprid, metolachlor, and atrazine parameters were analysed using clothianidin-d3, thiamethoxam-d3, imidacloprid-d4, acetamiprid-d3, metolachlor-d6, and atrazine-d5, respectively (pestanal class, purity $\geq 99.5 \%$ ). No internal standards were commercially available for dinotefuran, thiachloprid, cyantraniliprole, azoxystrobin and mefenoxam; instead, matrix-matched calibration curves were developed through injecting nine unique concentrations (ranging from $0.06 \mu \mathrm{g} / \mathrm{L}$ to $4.00 \mu \mathrm{g} / \mathrm{L}$ ) into the LC-ESI(+)-MS/MS system. The level of detection (LOD) and quantitation (LOQ) were respectively defined as 3 and 10 times the standard deviation of the peak signal-to-noise ratio found in the nine calibration curves. The percentage of recovery was obtained by injecting $0.05 \mathrm{ng}$ triplicates of each pesticide into $1 \mathrm{~L}$ of LC grade water and allowing the solution to equilibrate for three days 
at $40^{\circ} \mathrm{C}$ before extraction (Schaafsma et al., 2017). Results are presented as mean concentrations $(\mu \mathrm{g} / \mathrm{L})$ of the three subsamples. Water samples were re-extracted and re-analysed if there was a random injection error (measured as RSD in triplicate subsamples) greater than $100 \%$ around the LOD or $10 \%$ around the LOQ. A minimum of $18 \%$ of samples were re-extracted and re-analyzed for each sampling round.

\subsubsection{Crop Survey}

The Government of Canada does not provide data on local neonicotinoid use throughout the country. Field and farmer surveys were performed in order to estimate the land-rate application of neonicotinoids in both Norfolk and Lanark County.

The field survey was conducted using crop data for the years 2015 and 2016 (Agriculture and Agri-Food Canada, 2017). The data were noted for those years because half-lives indicate that any neonicotinoids detected in groundwater during the sampling timeframe were unlikely to originate in the years prior to 2015 (Table 4.1). All crop data that were acquired are at an accuracy of at least $85 \%$ at a spatial resolution of $30 \mathrm{~m}$ (Agriculture and Agri-Food Canada, 2017).

Table 4.1: Physical properties of clothianidin, imidacloprid, and thiamethoxam (Bonmatin et al., 2015; Hladik et al., 2014; Morrissey et al., 2015). Note that clothianidin and thiamethoxam are significantly more persistent in soil compared to water.

\begin{tabular}{cccccc}
\hline Neonicotinoid & $\begin{array}{c}\text { Log } \\
K_{O C}\end{array}$ & $\begin{array}{c}\text { Soil } \\
\text { Degradation } \\
\text { Half-Life }(\mathrm{d})\end{array}$ & $\begin{array}{c}\text { Solubility in } \\
\text { water at } 20^{\circ} \mathrm{C} \text { at } \\
\mathrm{pH} \mathrm{7} \mathrm{(mg/L)}\end{array}$ & $\begin{array}{c}\text { Aqueous } \\
\text { Photolysis DT50 } \\
\text { at pH 7 (d) }\end{array}$ & $\begin{array}{c}\text { Aqueous } \\
\text { Dissipation } \\
\text { Half-Life (d) }\end{array}$ \\
\hline Clothianidin & 2.1 & 545 & 340 (moderate) & 0.1 & 40.3 \\
Imidacloprid & $2.1-2.5$ & 191 & 610 (high) & 0.2 & 30 \\
Thiamethoxam & 1.8 & 50 & 4100 (high) & 2.7 & 30.6 \\
\hline
\end{tabular}

In order to estimate the quantity of land-applied neonicotinoids, a survey was conducted in February of 2017 that targeted maize, soybean, and wheat farmers (Appendix D - Farmer Survey Questionnaire). These three crops are prevalent in the two regions and commonly use neonicotinoids as a seed coating or foliar treatment (Agriculture and Agri-Food Canada, 2017; OMAFRA, 2016). The intention of the survey was to determine the types of neonicotinoids that are typically used as a seed coating or foliar spray in the two regions. Farmers were asked about the types of neonicotinoid seed coatings that they have used, the number of seeds sown per unit area with that seed coating, and the land area that is used for each neonicotinoid-treated crop. The field crop protection guide details the quantity of neonicotinoids typically used for each seed coating or foliar spray throughout Ontario (OMAFRA, 2016). Paired together, the farmer survey and field crop protection guide provide a reasonable quantitation of land-applied neonicotinoids in the two regions. 


\subsubsection{Numerical and Analytical Modelling}

Neonicotinoid transport was investigated using numerical and analytical models for the monitoring wells with groundwater elevation data and any clothianidin or thiamethoxam detections above the LOQ. The intention of these modeling exercises was to determine what factors led to the different neonicotinoid concentrations that were observed. The numerical model Hydrus 1D (Šimůnek et al., 2013) was used to simulate flow and transport through the vadose zone in Norfolk County, while the analytical Ogata-Banks solution (Ogata and Banks, 1961; Van Genuchten, 1981) was used to simulate transport through the saturated subsurface. In Lanark County, Hydrus 1D was used to simulate flow through the overburden; the analytical solution for one-dimensional advection with matrix diffusion (Sudicky, 1988; Sudicky and Frind, 1982; Tang et al., 1981) was used to analyze flow in parallel plate fractures. Hydrus 1D was used to model the quaternary unsaturated zone in order to manipulate and assess the effects of parameters such as precipitation and evapotranspiration on neonicotinoid transport. A slug concentration that approximates the output from Hydrus 1D at the water table was used as the input for the Ogata-Banks solution to simulate transport in the saturated zone in Norfolk County. For the Lanark County site, the analytical solution for contaminant transport in a discrete fracture (one-dimensional advection with matrix diffusion) was used in order to incorporate the effects of dispersion in the fracture network.

Soil texture and organic matter content was determined through sieve, hydrometer, and loss-on-ignition tests. These were carried out at University of Guelph using collected soil samples. Hydrometer tests (Bowles, 1992) were conducted to determine the soil texture at each monitoring well that was being modelled. This involved oven-heating the samples overnight at $105^{\circ} \mathrm{C}$ to remove moisture and then running a sieve test to determine sand content and the amount of fine material passing the No. $200(0.075 \mathrm{~mm})$ sieve. In order to determine silt and clay content, $50 \mathrm{~g}$ of the fine material was mixed with a $4 \%$ sodium hexametaphosphate solution, manually mixed, allowed to settle for $1 \mathrm{~h}$, mechanically mixed, and then monitored for $48 \mathrm{~h}$ using a hydrometer and thermometer. The loss-on-ignition tests (Smith and Atkinson, 1975) were performed to determine the organic matter content for the overburden materials in the vicinity of the monitoring wells that were being modelled. This involved oven-heating samples overnight at $105^{\circ} \mathrm{C}$ to remove hygroscopic moisture before heating samples at $400^{\circ} \mathrm{C}$ for $8 \mathrm{~h}$ to burn off organic matter. After samples were cooled, organic matter content was calculated by finding the difference in weight before and after the samples were placed in the $400^{\circ} \mathrm{C}$ oven. Triplicates were analyzed for each site to ensure accuracy. 
Hydrus 1D requires input parameters such as soil water content, soil water retention function parameters, hydraulic conductivity, and tortuosity. In order to quantify these parameters, layer composition inputs (\% sand, \% silt, and \% clay) were input into the Rosetta Lite Neural Network predictor (Schaap and Brown, 2003). Layer compositions were determined through borehole logs along with sieve and hydrometer tests that were performed on the shallow soil.

The land-rate application of clothianidin and thiamethoxam was found using crop surveys, farmer surveys, along with information from the Agriculture and Agri-Food Canada and the Ontario Ministry of Agriculture, Food, and Rural Affairs (OMAFRA) (Agriculture and Agri-Food Canada, 2017; OMAFRA, 2016). These data offer a reasonable estimation of neonicotinoid application rates on the ground surface, but they do not provide information on neonicotinoid leaching rates. Forero (2017) took soil cores to a depth of $35 \mathrm{~cm}$ in August 2014 at a southwestern Ontario maize farm. Forero (2017) used LC-MS/MS at the University of Guelph Ridgetown Campus to determine neonicotinoid concentrations in the core at $0-5 \mathrm{~cm}, 5-15 \mathrm{~cm}, 15-25 \mathrm{~cm}$, and $25-35 \mathrm{~cm}$ segments. That study also performed sieve, hydrometer, and loss-on-ignition tests on the bulk core to determine soil texture and organic matter content. Clothianidin and thiamethoxam concentrations from Forero (2017) were used as model inputs for the core that most closely resembled the soil near the monitoring wells that were being modelled.

Samples from Forero (2017) were used for as the Hydrus 1D input because they were taken to a depth of $35 \mathrm{~cm}$ in an agricultural field; the soil samples taken in July 2016 were from road easements and ditches to a depth of only $15 \mathrm{~cm}$. Additionally, any neonicotinoid concentrations that were detected in the July 2016 soil samples were likely sourced from runoff and/or soil dust (Schaafsma et al., 2015). It is more likely that neonicotinoid concentrations in groundwater were sourced from concentrations found in agricultural fields as opposed to the lower, secondary sources of the contaminant found in nearby ditches (see Appendix B - Raw Sampling Data for soil sampling concentrations).

\subsection{Results and Discussion}

The results of the monitoring well and soil sampling program, crop surveys, and mathematical modelling exercises are detailed in the following sections. Data are described and considered in order to evaluate the processes by which neonicotinoids are transported to groundwater.

\subsubsection{Field Sampling Results}

In this groundwater field study, one neonicotinoid was detected above the LOD in 17 samples, and at least one neonicotinoid detected above the LOQ in another 9 samples (Table 4.2). All neonicotinoid detections in the other 202 samples were below the LOD. Thus, $4.1 \%(8.5 \%)$ and 
$3.8 \%(13.3 \%)$ of the samples had neonicotinoids above the LOQ (LOD) in Norfolk and Lanark County, respectively. There was only one sample (TW17 in April 2016) in which multiple neonicotinoids were detected above the LOD or LOQ. Both samples that were collected in the Tay River in August 2016 had no pesticide detections above the LOD. See Appendix B - Raw Sampling Data for tables of all of the groundwater and soil sampling results.

Table 4.2: Incidence of six neonicotinoids, two fungicides, two herbicides, and one ryanoid in 228 water samples collected from Long Point Monitoring Wells $(n=122)$ and Tay Wells $(n=104)$ between 2016 and 2017. Two additional samples were taken from the Tay River near TW4 and TW21 in August 2016. These two samples had no pesticide detections above the LOD. The LOD and LOQ vary for each round of samples and their standard deviation was calculated directly from calibration curves.

\begin{tabular}{|c|c|c|c|c|c|c|c|c|}
\hline \multirow{2}{*}{ Pesticides } & \multirow{2}{*}{$\begin{array}{c}\mathrm{LOD} \pm S D \\
\mu \mathrm{g} / \mathrm{L}\end{array}$} & \multirow{2}{*}{$\begin{array}{c}\mathrm{LOQ} \pm S D \\
\mu \mathrm{g} / \mathrm{L}\end{array}$} & \multicolumn{2}{|c|}{$<L O D$} & \multicolumn{2}{|c|}{$>\mathrm{LOD}<\mathrm{LOQ}$} & \multicolumn{2}{|c|}{$>\mathrm{LOQ}$} \\
\hline & & & $\mathrm{n}$ & $(\%)$ & $\mathrm{n}$ & $(\%)$ & $\mathrm{n}$ & $(\%)$ \\
\hline \multicolumn{9}{|l|}{ Neonicotinoids } \\
\hline Acetamiprid & $0.008 \pm 0.001$ & $0.025 \pm 0.003$ & 228 & $(100)$ & 0 & $(0)$ & 0 & $(0)$ \\
\hline Clothianidin & $0.043 \pm 0.006$ & $0.114 \pm 0.017$ & 216 & $(94.7)$ & 7 & $(3.1)$ & 5 & $(2.2)$ \\
\hline Dinotefuran & $0.009 \pm 0.012$ & $0.025 \pm 0.035$ & 228 & $(100)$ & 0 & (0) & 0 & (0) \\
\hline Imidacloprid & $0.025 \pm 0.012$ & $0.076 \pm 0.034$ & 225 & $(98.7)$ & 1 & $(0.4)$ & 2 & $(0.9)$ \\
\hline Thiacloprid & $0.012 \pm 0.041$ & $0.032 \pm 0.128$ & 228 & $(100)$ & 0 & $(0)$ & 0 & $(0)$ \\
\hline $\begin{array}{c}\text { Thiamethoxam } \\
\text { Fungicides }\end{array}$ & $0.012 \pm 0.001$ & $0.038 \pm 0.003$ & 216 & $(94.7)$ & 9 & (3.9) & 3 & $(1.3)$ \\
\hline Azoxystrobin & $0.007 \pm 0.001$ & $0.017 \pm 0.004$ & 228 & $(100)$ & 0 & $(0)$ & 0 & $(0)$ \\
\hline $\begin{array}{c}\text { Mefenoxam* } \\
\text { Herbicides }\end{array}$ & $0.003 \pm 0.002$ & $0.008 \pm 0.004$ & 173 & $(93.0)$ & 5 & $(2.7)$ & 8 & $(4.3)$ \\
\hline Atrazine & $0.004 \pm 0.002$ & $0.013 \pm 0.005$ & 207 & $(90.8)$ & 4 & $(1.8)$ & 17 & $(7.5)$ \\
\hline $\begin{array}{c}\text { Metolachlor* } \\
\text { Ryanoid }\end{array}$ & $0.015 \pm 0.006$ & $0.033 \pm 0.013$ & 152 & $(81.7)$ & 10 & $(5.4)$ & 24 & (12.9) \\
\hline Cyantraniliprole & $0.005 \pm 0.003$ & $0.016 \pm 0.008$ & 227 & $(99.6)$ & 0 & $(0)$ & 1 & $(0.4)$ \\
\hline
\end{tabular}

*Samples taken in April 2016 were not analyzed for this compound.

$\mathrm{LOD}=$ level of detection, $\mathrm{LOQ}=$ level of quantitation, $\mathrm{SD}=$ standard deviation, $<\mathrm{LOD}=$ not detected, $>\mathrm{LOD}<\mathrm{LOQ}=$ trace levels, $>\mathrm{LOQ}=$ quantifiable levels.

Triplicate field samples from April 2016 revealed that trace detections can inconsistently occur in samples collected from the same monitoring interval. However, the detection frequency was consistent when detections below the LOQ were treated as negative. As a result, all sample concentrations that were measured below the LOQ are hereafter considered inconclusive; analysis will focus on samples with neonicotinoid detections above the LOQ.

The maximum clothianidin concentration of $2.09 \mu \mathrm{g} / \mathrm{L}$ was detected at LP-MW-08D in August 2016, the maximum imidacloprid concentration of $0.07 \mu \mathrm{g} / \mathrm{L}$ was detected at LP-MW-08S in July 2016, and the maximum thiamethoxam concentration of $0.46 \mu \mathrm{g} / \mathrm{L}$ was detected at TW17 in April 2016. All other analyzed neonicotinoids - acetamiprid, dinotefuran, thiacloprid - are not 
recommended for use in Ontario (OMAFRA, 2016) and were not detected above the LOD at any point throughout the sampling regime. All detections above the LOQ for clothianidin, imidacloprid, and thiamethoxam in each sampling round are presented in Table 4.3. It should be noted that all imidacloprid detections occurred in well LP-MW-08S in Norfolk County, while all thiamethoxam detections occurred in well TW17 in Lanark County. Clothianidin detections occurred at TW17, LP-MW-02D, LP-MW-08D, LP-MW-11D, and TW1D.

Table 4.3: List of clothianidin, imidacloprid, and thiamethoxam detections and their detection frequency. All neonicotinoid detections above the LOQ are listed with the concentration shown in brackets.

\begin{tabular}{|c|c|c|c|c|}
\hline $\begin{array}{l}\text { Sampling } \\
\text { Round }\end{array}$ & $\begin{array}{l}\text { Clothianidin } \\
\qquad(\mu \mathrm{g} / \mathrm{L})\end{array}$ & $\begin{array}{l}\text { Imidacloprid } \\
\qquad(\mu \mathrm{g} / \mathrm{L})\end{array}$ & $\begin{array}{c}\text { Thiamethoxam } \\
(\mu \mathrm{g} / \mathrm{L})\end{array}$ & $\begin{array}{c}\text { Number of } \\
\text { samples }\end{array}$ \\
\hline April 2016 & TW17 (0.095) & --- & TW17 (0.46) & 50 \\
\hline July 2016 & --- & LP-MW-08S (0.07) & TW17 (0.061) & 44 \\
\hline August 2016 & $\begin{array}{l}\text { LP-MW-02D (1.68) } \\
\text { LP-MW-08D (2.09) } \\
\text { LP-MW-11D (1.67) } \\
\text { TW1D (1.16) }\end{array}$ & LP-MW-08S (0.03) & --- & 51 \\
\hline November 2016 & --- & --- & --- & 41 \\
\hline April 2017 & --- & --- & TW17 (0.42) & 42 \\
\hline $\begin{array}{c}\text { Detection } \\
\text { Frequency (\%) }\end{array}$ & 2.2 & 0.9 & 1.3 & 228 \\
\hline
\end{tabular}

The concentration of imidacloprid in LP-MW-08S during July 2016 and August 2016 sampling were $0.070 \mu \mathrm{g} / \mathrm{L}$ and $0.031 \mu \mathrm{g} / \mathrm{L}$, respectively. These detections were marginally above the LOQ values of $0.066 \mu \mathrm{g} / \mathrm{L}$ in July 2016 , and $0.030 \mu \mathrm{g} / \mathrm{L}$ in August 2016. Juxtaposing this, thiamethoxam concentrations were higher at $0.46 \mu \mathrm{g} / \mathrm{L}, 0.061 \mu \mathrm{g} / \mathrm{L}$, and $0.42 \mu \mathrm{g} / \mathrm{L}$. These concentrations were significantly above the LOQ for each sampling round $-0.042 \mu \mathrm{g} / \mathrm{L}, 0.028 \mu \mathrm{g} / \mathrm{L}$, and $0.068 \mu \mathrm{g} / \mathrm{L}$, respectively.

According to the farmer survey, the detection of clothianidin and thiamethoxam in groundwater is consistent with the types of neonicotinoids that are used in the two regions (Table 4.4). Crop data revealed that in 2015 and 2016, soybeans and maize were the prevalent crops that used neonicotinoids in the two regions (Figure 4.2). In Norfolk County, clothianidin and thiamethoxam 
seed coatings are used on typically maize hybrids and soybean varieties, respectively. In Lanark County, thiamethoxam seed coatings are typically used on both maize hybrids and soybean varieties.

Table 4.4: Typical application rates of neonicotinoids in Norfolk and Lanark County. The types of seed dressings and number of seeds per acre are based on responses to the farmer survey (Appendix D - Farmer Survey Questionnaire). Treatment rates are based on information from OMAFRA (2016) and PMRA Pesticide Labels (Syngenta Canada Inc., 2016). Note that application rates associated with soybeans are larger than rates associated with maize crops as a result of seeding rate.

\begin{tabular}{cccccc}
\hline Location & Crop & Neonicotinoid & $\begin{array}{c}\text { Treatment } \\
\text { Rate } \\
\text { (mg a.i./seed) }\end{array}$ & $\begin{array}{c}\text { Seeding } \\
\text { Rate } \\
\text { (seeds/ha) }\end{array}$ & $\begin{array}{c}\text { Neonicotinoid } \\
\text { Application } \\
\text { Rate (g a.i./ha) }\end{array}$ \\
\hline Norfolk & Corn & Clothianidin & 0.25 & 74,000 & 18.5 \\
County & Soybeans & Thiamethoxam & 0.076 & 432,000 & 32.8 \\
Lanark & Corn & Thiamethoxam & 0.25 & 79,000 & 19.8 \\
County & Soybeans & Thiamethoxam & 0.076 & 402,000 & 30.6 \\
\hline
\end{tabular}

a.i. = active ingredient. 

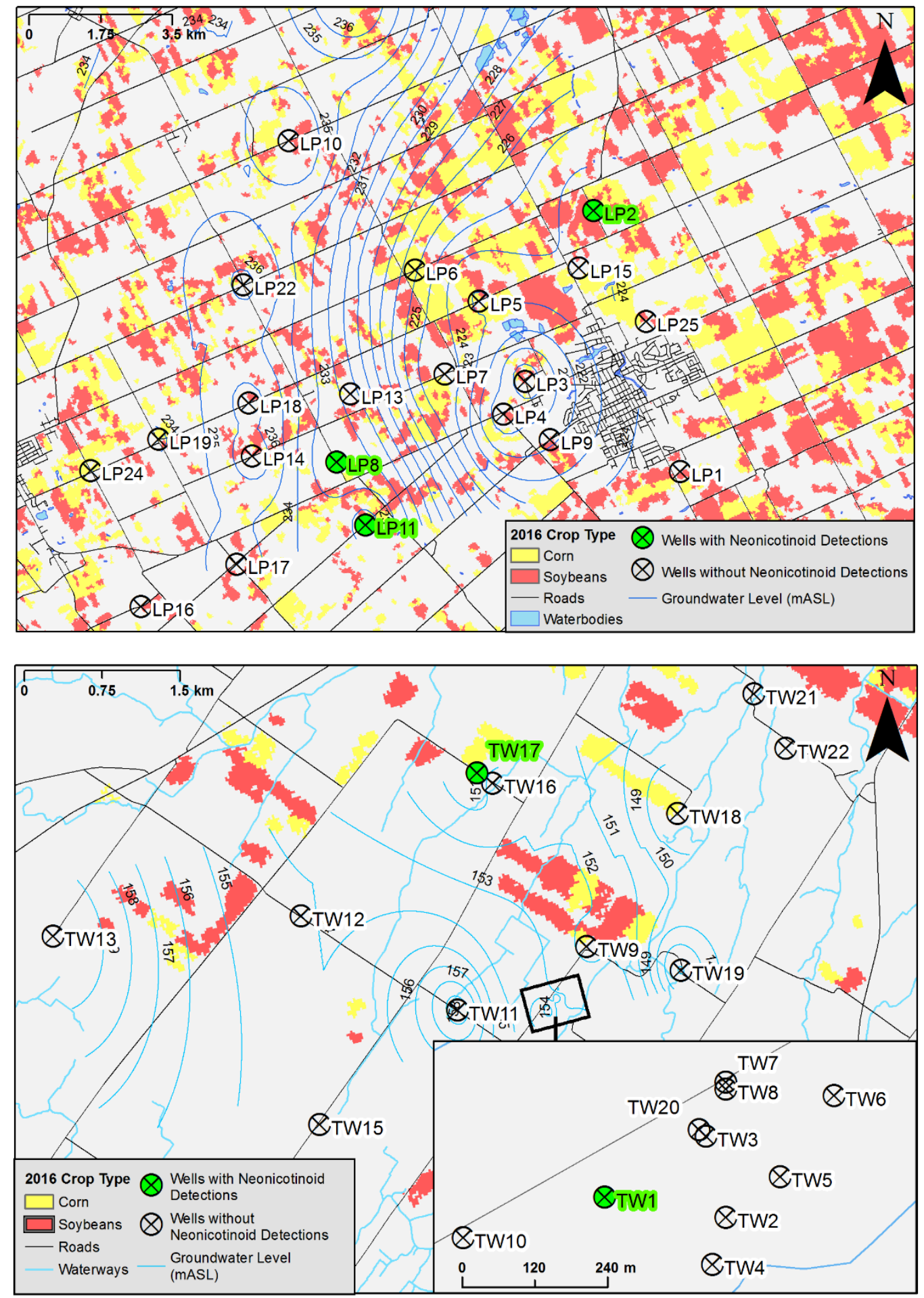

Figure 4.2: 2016 crop map of research sites in Norfolk County (top) and Lanark County (bottom) (Agriculture and Agri-Food Canada, 2017). Wells with detections above the LOQ are show with a green background. The local groundwater flow direction is contoured from static water levels retrieved in April 2016 and is measured in metres above sea level.

Clothianidin concentrations were almost consistently inconclusive at all monitoring wells during every sampling round, exempting peaks at four monitoring intervals in August 2016 and the 
$0.095 \mu \mathrm{g} / \mathrm{L}$ concentration measured at TW17 in April 2016. The concentration found in TW17 is noteworthy due to the same well having positive concentrations of thiamethoxam in three out of five sampling rounds; the observed clothianidin concentration could be a metabolite of thiamethoxam (Pesticide Properties Database, 2017). Other clothianidin concentrations peaked in August 2016. Concentrations of $1.68 \mu \mathrm{g} / \mathrm{L}, 2.09 \mu \mathrm{g} / \mathrm{L}, 1.67 \mu \mathrm{g} / \mathrm{L}$, and $1.16 \mu \mathrm{g} / \mathrm{L}$ occurred at LP-MW-02D, LP-MW-08D, LP-MW-11D, and TW1D within this timeframe. This suggests that clothianidin may occur in groundwater in an annual pulse; a finer sampling timeframe would be necessary to confirm this theory.

The contamination at TW1D is consistent with past studies on groundwater quality in Lanark County. TW1D has been impacted by nitrate, and $E$. coli from an upgradient manure source (Levison et al., 2012; Levison and Novakowski, 2009) as well as PBDE congeners (Levison et al., 2012). Studies also show that nitrate and PBDE congener concentrations have peaked at TW1D in August of previous years. This has been partially attributed to low groundwater elevations towards the end of the summer baseflow period - nitrate concentrations typically decline at this location due to the effects of dilution after autumn precipitation (Levison and Novakowski, 2009). Additionally, TW1 was drilled into a rock outcrop; rapid recharge and associated contaminant transport can occur through outcrops (Gleeson et al., 2009b; Levison and Novakowski, 2012; Praamsma et al., 2009).

The highest clothianidin concentrations in Norfolk County were detected at three monitoring intervals in August 2016, but it is possible that a similar contamination peak occurred at other intervals before or after that sampling round. Clothianidin contamination in Norfolk County coincides with summer baseflow conditions; no neonicotinoids were detected in the region after autumn precipitation events. Correlations between nitrate and clothianidin concentrations at LP-MW-02D and LP-MW-11D likely mean that clothianidin peaks occur in groundwater prior to dilution (Figure 4.3). Additionally, the half-life of clothianidin in the water phase of water-sediment systems is 40.3 days (Pesticide Properties Database, 2017)-degradation likely plays a factor in the decline of clothianidin concentrations during the autumn months.

TW17 differs from the other monitoring intervals in that it is the only well in which both thiamethoxam and clothianidin were detected during the spring freshet sampling rounds. Thiamethoxam was detected in 2016 and 2017, while clothianidin was only detected in 2016. These April neonicotinoid detections appear to correlate with the presence of nitrate at TW17 (Figure 4.3). This seemingly uniform movement of nitrate and neonicotinoids to the well likely results from a low permeability ( $0.6 \mathrm{~m}$ thick) soil layer, delaying the release of both contaminants 
until they are transported to groundwater by the spring freshet (Figure 4.4). Additionally, thiamethoxam is immobile in dry soil (Bonmatin et al., 2015). This likely exacerbates the delayed release of thiamethoxam to TW17. During the July 2016 soil sampling, concentrations of clothianidin and thiamethoxam $(6.33 \mathrm{ng} / \mathrm{g}$ and $1.01 \mathrm{ng} / \mathrm{g}$ respectively) were highest in the overburden near TW17 (Appendix B - Raw Sampling Data). This further supports the theory that there is a delayed release of neonicotinoid residues from this relatively low permeability overburden. Thiamethoxam has a half-life in soil of 50 days (Hladik et al., 2014); it is possible that the observed freshet peaks at TW17 were lower than clothianidin peaks in August 2016 due to degradation that occurred in soil. It is also possible that these thiamethoxam peaks were lower due to dilution that occurred in the $24 \mathrm{~m}$ open well. The July 2016 observation of thiamethoxam at TW17 was likely the tail end of that contamination, which could mean that thiamethoxam is released more gradually than clothianidin.

Past studies have found that atrazine can behave similarly to clothianidin and thiamethoxam in soil and surface water (Schaafsma et al., 2017). Atrazine is typically applied after seed sowing during pre- and post-mergence broadleaf weeds. However, there were no apparent correlations between the incidence of these two neonicotinoids and atrazine in groundwater. Furthermore, no correlations were apparent between these neonicotinoids and any other analyzed contaminant (azoxystrobin, cyantraniliprole, mefenoxam, and metolachlor) or field parameters measured by the handheld YSI (temperature, dissolved oxygen, electrical conductivity, and ORP) (Appendix H - Field Parameters and Lab Analysis Graphs). Nitrate was the only contaminant that appeared to behave in a similar manner to clothianidin and thiamethoxam in groundwater (Figure 4.3).

It should also be noted that preliminary groundwater sampling occurred at five domestic wells in agricultural-intensive areas within southwestern Ontario in January 2016. This sampling regime found no neonicotinoids above the LOD. These domestic wells were screened between $27 \mathrm{~m}$ and $37 \mathrm{~m}$ below ground surface into a predominately sandy aquifer. 

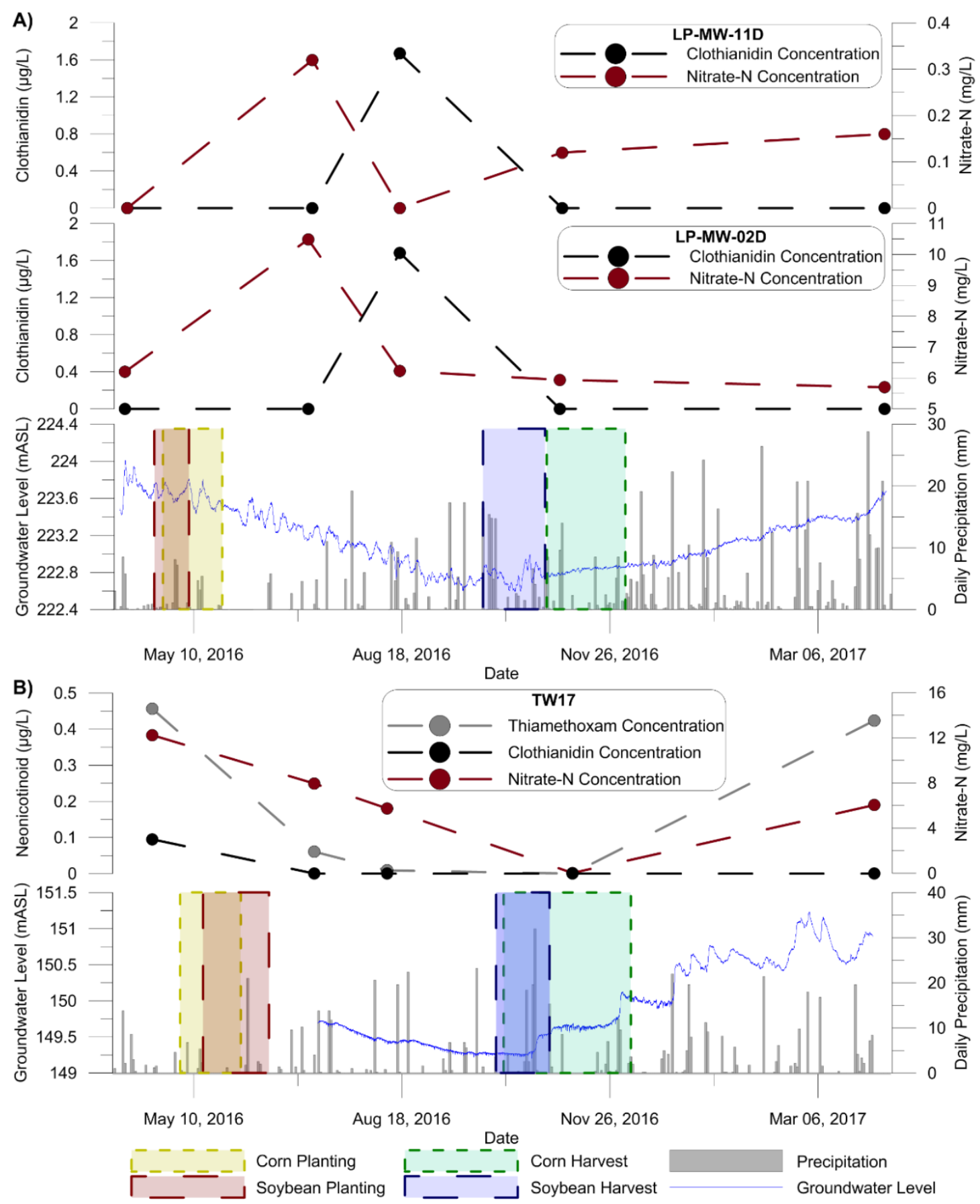

Figure 4.3: Neonicotinoid and nitrate concentrations at monitoring wells in Norfolk and Lanark County. A) Clothianidin peaks at LP-MW-02D and LP-MW-11D occur roughly one month after nitrate peaks. This is likely due to the application of clothianidin as a seed dressing several weeks after manure (a possible nitrate source in this instance) is spread on agricultural fields. Precipitation and the groundwater level at LP-MW-02M is shown against typical crop planting and harvesting times in Norfolk County. The groundwater level at LP-MW-02M was found to closely resemble the level at LP-MW-02D during static water level monitoring (Appendix B - Raw Sampling Data). Groundwater level data at LP-MW-11D are unavailable over large periods throughout the sampling regime due to the water level falling below the pressure transducer. B) Clothianidin, thiamethoxam, and nitrate-N peaks occur at TW17 during the spring freshet. Groundwater level data at TW17 are unavailable between April and July of 2016. Precipitation data are shown against typical crop planting and harvest times in Lanark County. 


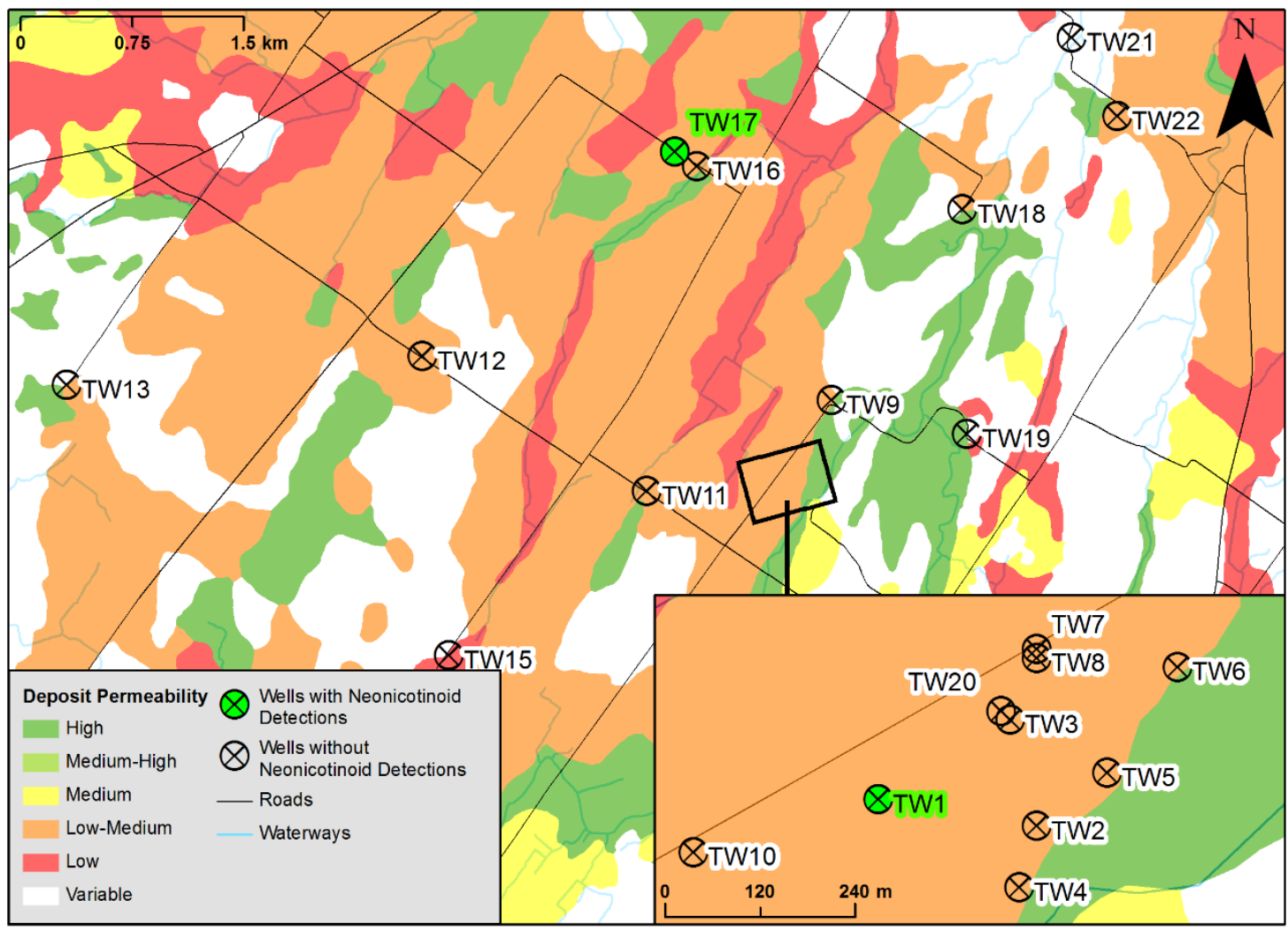

Figure 4.4: Deposit permeability map for the Lanark County research site (Ontario Geological Survey, 2010). Note that the relative overburden permeability near TW17 ranges from low to low-medium. This likely accounts for the delayed release of nitrate, clothianidin, and thiamethoxam from the overburden to the groundwater in that area.

\subsubsection{Mathematical Modelling}

Analytical and numerical models were used to analyze clothianidin transport at LP-MW-02 and thiamethoxam transport at TW17. Imidacloprid was not measured at concentrations that justified modelling.

Contaminant source concentrations were determined from soil core data compiled by Forero (2017). The core with the most similar texture and organic matter content to the soil at LP-MW-02 and TW17 was used for the clothianidin and thiamethoxam source concentration for each mathematical model (Table 4.5).

Table 4.5: Results from sieve, hydrometer, and loss-on-ignition tests for the overburden near LP-MW-02 and TW17. Concentrations of clothianidin and thiamethoxam were measured for the bulk reference core and used as inputs to the Hydrus 1D models (Forero, 2017).

\begin{tabular}{cccc}
\hline Soil Characteristic & LP-MW-02 & TW17 & $\begin{array}{c}\text { Reference Core } \\
\text { (Forero, 2017) }\end{array}$ \\
\hline \% Sand & 89.5 & 88.0 & 62 \\
\% Silt & 9.6 & 10.9 & 10 \\
\% Clay & 0.9 & 1.1 & 28 \\
\% Organic Matter & 2.35 & 6.9 & 2.3 \\
\hline
\end{tabular}


These soil cores were sampled in August 2014. In order to use the neonicotinoid concentrations detected in that core as the model contaminant input, an assumption was made that the August 2014 core represents conditions after May planting at LP-MW-02 and TW17. This opens a potential for error in that neonicotinoid leaching and moderate degradation may have occurred prior to August 2014 at that maize field. Thus, the modelled concentration peak of both neonicotinoids is lower than concentrations that were encountered in the field. As a result, these models were not used to analyze neonicotinoid concentrations that were found in the field; rather, they were used to analyze the patterns of clothianidin and thiamethoxam transport to groundwater at both research sites.

It should also be noted that the concentration of thiamethoxam is significantly lower in the soil core compared to clothianidin (Table 4.6). It is speculated that thiamethoxam was most recently applied as a seed dressing to the soybean varieties that were sown in 2013, while clothianidin was used as a seed dressing on the maize hybrids that were planted in 2014. As a result, the modelling exercises found thiamethoxam concentrations in groundwater that are significantly lower than those of clothianidin. It is important to note that the concentrations found through these modelling exercises are not necessarily representative of field conditions. Instead, the patterns of how each neonicotinoid is transported to groundwater will be used to analyze field data.

Table 4.6: Concentrations of clothianidin and thiamethoxam in the reference core (Forero, 2017). These concentrations were used as inputs to the Hydrus 1D models. The clothianidin concentration is higher than the concentration from July 2016 soil sampling at LP-MW-02 $(0.75 \mu \mathrm{g} / \mathrm{L})$, while the thiamethoxam concentration is lower than what was detected in the soil near TW17 in July $2016(1.01 \mu \mathrm{g} / \mathrm{L})$. Thiamethoxam concentrations in the reference core (Forero, 2017) are residual concentrations from the 2013 planting season. This is likely why the overburden near TW17 has higher thiamethoxam concentrations compared to what was found in August 2014 by Forero (2017).

\begin{tabular}{ccc}
\hline $\begin{array}{c}\text { Depth Below } \\
\text { Ground Surface }(\mathrm{cm})\end{array}$ & $\begin{array}{c}\text { Clothianidin } \\
(\mu \mathrm{g} / \mathrm{L})\end{array}$ & $\begin{array}{c}\text { Thiamethoxam } \\
(\mu \mathrm{g} / \mathrm{L})\end{array}$ \\
\hline $0-5$ & 17.07 & 0.28 \\
$5-15$ & 1.26 & 0.35 \\
$15-25$ & 12.08 & 0.45 \\
$25-35$ & 7.43 & 0.32 \\
\hline
\end{tabular}

Layer composition inputs (\% sand, \% silt, and \% clay) were determined for LP-MW-02 and TW17 through qualitative estimates (silty-sand, sandy-clay, etc.) provided by borehole logs along with hydrometer and sieve tests that were performed on the shallow soil (Table 4.7). This compositional information was input into the Rosetta Lite Neural Network predictor (Schaap and 
Brown, 2003) and outputs were adjusted in order to match the simulated output concentrations with those observed in the field.

In Norfolk County, the numerical model Hydrus 1D was used to simulate transport through the vadose zone. This model was composed of four materials that were compositionally similar to soil packages interpreted by Marich (2010). The domain extended from the surface to $21 \mathrm{~m}$ below ground surface (BGS). It was composed of topsoil (to a depth of $0.5 \mathrm{mBGS}$ ), sand to silty sand (2.0 mBGS), clay to sand (10 mBGS), and sand (21 mBGS). The observation point was placed at approximately $10 \mathrm{mBGS}$, which is the average annual depth to the groundwater table at this location. Upper boundary conditions were precipitation, evapotranspiration, and runoff; the lower boundary condition was set as specified head, with values obtained from dynamic groundwater elevations recorded by a pressure transducer at LP-MW-02M (Figure 4.5). Evapotranspiration was calculated using the Penman-Montieth equation (Allen et al., 1998) with data obtained from Environment and Climate Change Canada (2017) and Stackhouse et al. (2015). Leaf area index (LAI) data were obtained from NASA Earth Observations (2017). Root water uptake associated with maize was also simulated on the ground surface. This model was run to simulate the period between May 1 and October 31 of 2016. A modified version of the model was also run beginning in September of 2014 in order to confirm that this increased spin-up period did not influence the release of the contaminant to the saturated subsurface (Appendix $E$ - Mathematical Modelling Inputs). 
Table 4.7: Key input parameters for the Hydrus 1D models at LP-MW-02 and TW17. Note that LP-MW-02 is composed of four quaternary material layers, whereas TW17 only includes the thin till over the fractured bedrock.

\begin{tabular}{|c|c|c|c|c|c|c|}
\hline \multirow[b]{2}{*}{ Parameter } & \multicolumn{4}{|c|}{ LP-MW-02 (clothianidin) } & \multirow{2}{*}{\begin{tabular}{|c}
$\begin{array}{c}\text { TW17 } \\
\text { (thiamethoxam) }\end{array}$ \\
Overburden
\end{tabular}} & \multirow[b]{2}{*}{ Source } \\
\hline & $\begin{array}{c}\text { Material } \\
1 \\
\end{array}$ & $\begin{array}{l}\text { Material } \\
2 \\
\end{array}$ & $\begin{array}{c}\text { Material } \\
3 \\
\end{array}$ & $\begin{array}{c}\text { Material } \\
4 \\
\end{array}$ & & \\
\hline Textural Class & Sand & $\begin{array}{l}\text { Silty } \\
\text { Sand }\end{array}$ & $\begin{array}{l}\text { Sandy } \\
\text { Clay }\end{array}$ & $\begin{array}{l}\text { Coarse } \\
\text { Sand }\end{array}$ & Sand & Borehole logs \\
\hline $\begin{array}{l}\text { Material Depth } \\
\quad(\mathrm{mBGS})\end{array}$ & $0-0.5$ & $0.5-2$ & $2-10$ & $10-21$ & $0-0.6$ & --- \\
\hline $\begin{array}{c}\text { Saturated Hydraulic } \\
\text { Conductivity }(\mathrm{m} / \mathrm{d})\end{array}$ & 3.42 & 1.05 & 0.80 & 6.43 & $8.00 \times 10^{-3}$ * & $\begin{array}{l}\text { Schaap and } \\
\text { Brown (2003) }\end{array}$ \\
\hline $\begin{array}{l}\text { Bulk Density } \\
\qquad\left(\mathrm{kg} / \mathrm{m}^{3}\right)\end{array}$ & 1600 & 1400 & 1700 & 1400 & 2000 & $\begin{array}{l}\text { United States } \\
\text { Department of } \\
\text { Agriculture } \\
(2017)\end{array}$ \\
\hline $\begin{array}{l}\text { Molecular } \\
\text { Dispersion } \\
\text { Coefficient in } \\
\text { Free Water } \\
\left(\times 10^{-12} \mathrm{~m}^{2} / \mathrm{d}\right)\end{array}$ & 1.00 & 1.00 & 1.00 & 1.00 & 1.00 & Fetter (1993) \\
\hline $\begin{array}{l}\text { Longitudinal } \\
\text { Dispersivity (m) }\end{array}$ & 0.05 & 0.20 & 1.00 & 2.10 & 6.00 & $\begin{array}{l}\text { Gelhar et al. } \\
\text { (1992) }\end{array}$ \\
\hline $\begin{array}{c}\text { Aqueous Rate } \\
\text { Constant } \\
\left(\times 10^{-2} \mathrm{~d}^{-1}\right)\end{array}$ & 1.72 & 1.72 & 1.72 & 1.72 & 2.27 & $\begin{array}{c}\text { Pesticide } \\
\text { Properties } \\
\text { Database }(2017)\end{array}$ \\
\hline $\begin{array}{l}\text { Soil Adsorption } \\
\text { Coefficient (-) }\end{array}$ & 2.89 & 1.5 & 0.246 & 0.246 & 3.59 & $\begin{array}{c}\text { Pesticide } \\
\text { Properties } \\
\text { Database }(2017)\end{array}$ \\
\hline
\end{tabular}

*Saturated hydraulic conductivity was reduced through iterations for the overburden at TW17. 


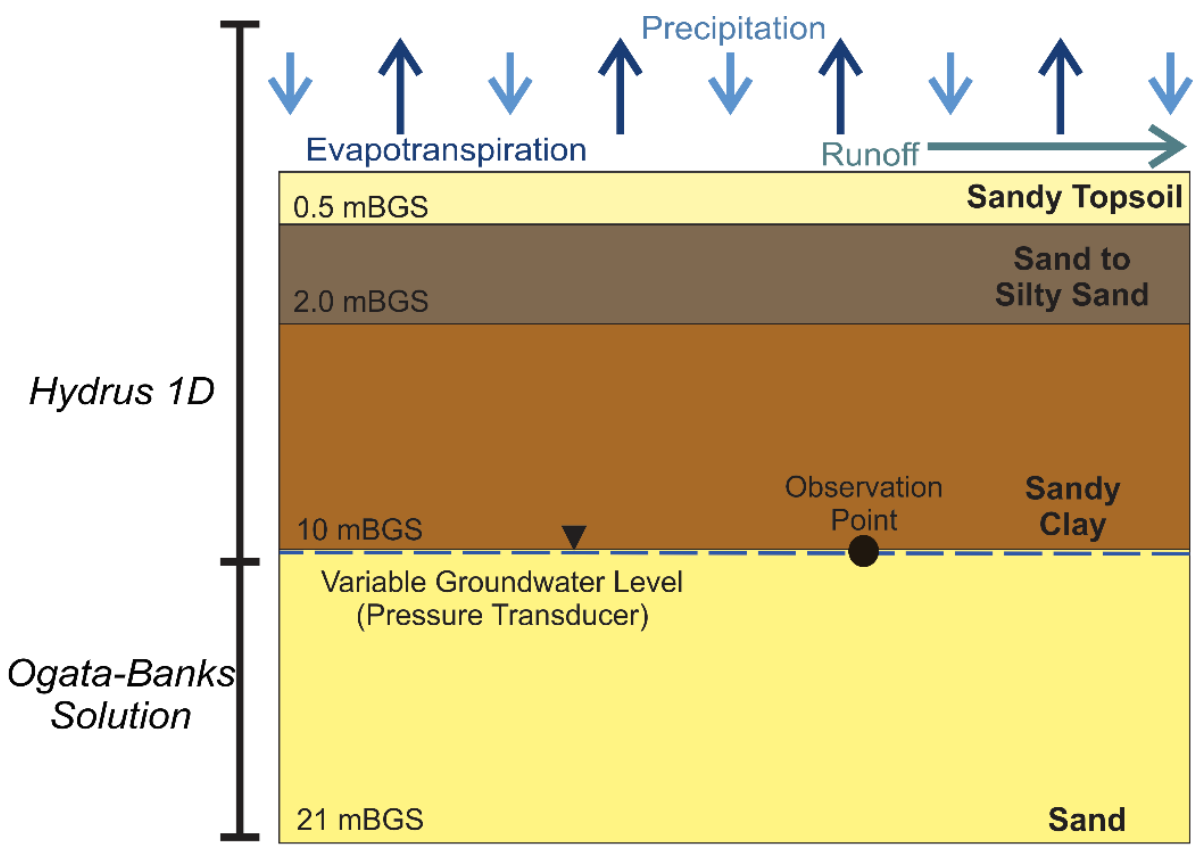

Figure 4.5: Conceptual diagram of the modelled 1D domain at LP-MW-02. For the Hydrus 1D model, precipitation, evapotranspiration, and runoff act as the upper boundary conditions, while the groundwater level from a pressure transducer is used as the lower boundary condition. Outputs from the Hydrus model at the groundwater table were input into the Ogata-Banks solution in order to assess the horizontal distance that clothianidin will typically travel in a sandy, unconfined aquifer.

The modelled clothianidin pulse through the LP-MW-02 vadose zone closely resembled the contamination peak that was observed in groundwater sampling. However, the modelled pulse occurred later during the year (late September) than the observed field contamination peak (mid-August) (Figure 4.11a). It is also possible that the contamination peak that was detected in August 2016 was not the peak concentration that occurred in the field; past studies have found clothianidin in groundwater at concentrations up to $3.33 \mu \mathrm{g} / \mathrm{L}$ (Huseth and Groves, 2014).

The Ogata-Banks solution was used to determine contaminant transport in the saturated subsurface using the Hydrus 1D outputs and soil composition information associated with a predominately sandy aquifer (Table 4.8). Specifically, outputs from Hydrus 1D were approximated as a slug input $(0.15 \mu \mathrm{g} / \mathrm{L}$ for 30 days $)$ and input into the Ogata-Banks solution. The results of this analytical model revealed that once the clothianidin pulse reaches the saturated zone, it can travel $10 \mathrm{~m}$ in 30 days and $50 \mathrm{~m}$ in 40 days at concentrations approaching the input concentration before gradually dissipating (Figure 4.6). This means that clothianidin concentrations observed in groundwater likely originate from nearby agricultural activities (Figure 4.7). 
Table 4.8: Inputs for the analytical Ogata-Banks solution in the LP-MW-02 saturated zone. This model was used in order to determine the movement of the clothianidin pulse in groundwater within a sandy, unconfined aquifer. The Ogata-Banks solution was evaluated using the spreadsheet developed by Craig (2014) based on Van Genuchten (1981).

\begin{tabular}{ccc}
\hline Parameter & Value & Source \\
\hline Source Concentration $(\mu \mathrm{g} / \mathrm{L})$ & 0.15 & Hydrus 1D unsaturated model \\
Hydraulic Gradient $(-)$ & 0.002 & Pressure transducer data \\
Hydraulic Conductivity $(\mathrm{m} / \mathrm{d})$ & 518.40 & Domenico and Schwartz (1990) \\
Porosity $(-)$ & 0.25 & Domenico and Schwartz (1990) \\
Calculated \\
Average Linear Groundwater Velocity $(\mathrm{m} / \mathrm{d})$ & 4.15 & Gelhar et al. (1992) \\
Dispersivity $(\mathrm{m})$ & 2 & Pesticide Properties Database \\
Soil Organic Carbon-Water Partitioning & 123 & (2017) \\
Coefficient & 1.67 & Calculated \\
Retardation Factor $(-)$ & 0.0172 & Pesticide Properties Database \\
Decay Coefficient $\left(\right.$ day $\left.^{-1}\right)$ & & (2017) \\
\hline
\end{tabular}

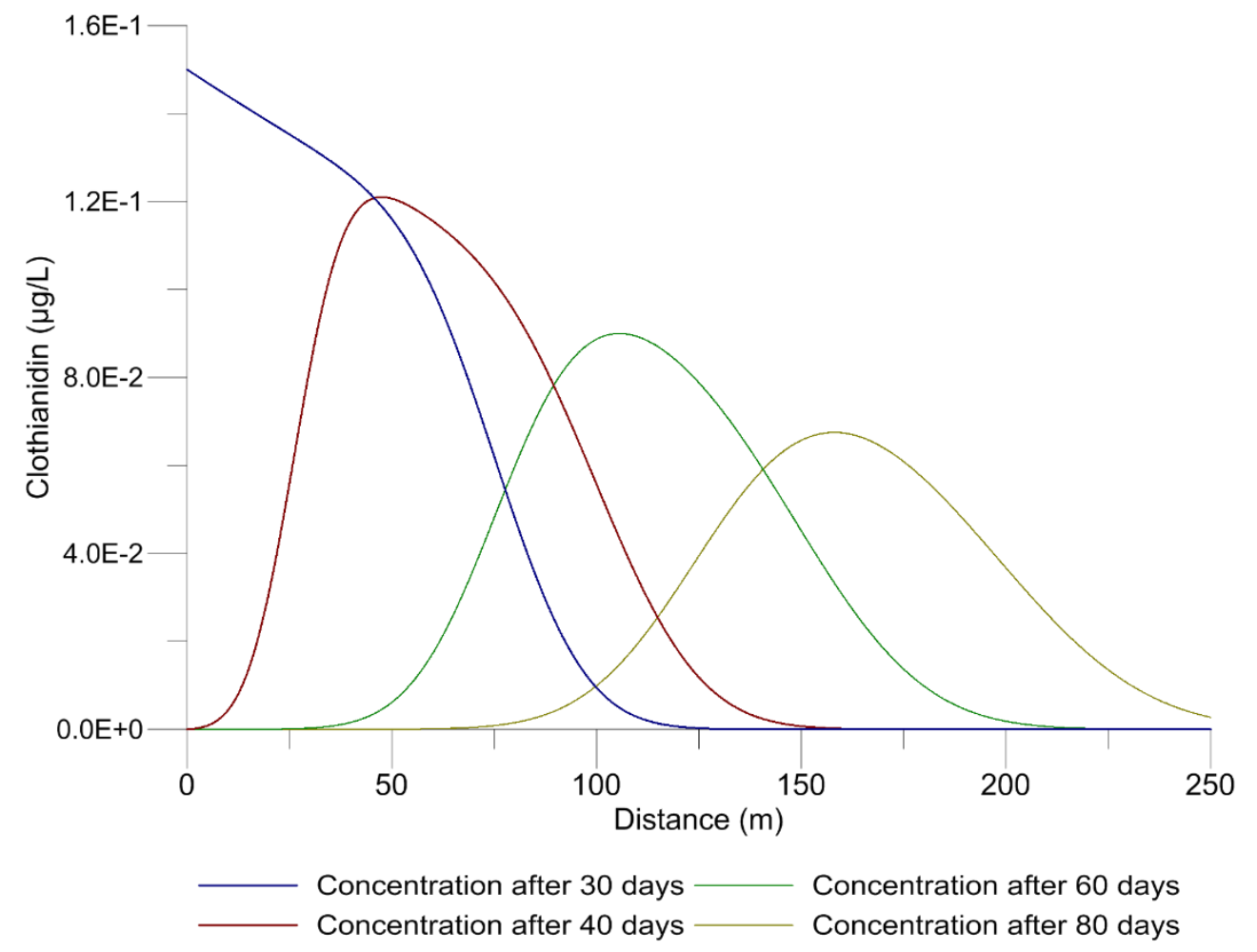

Figure 4.6: Breakthrough curves for clothianidin in the LP-MW-02 saturated zone. These were determined using the Ogata-Banks solution (Craig, 2014; Ogata and Banks, 1961; Van Genuchten, 1981) and reveal that clothianidin concentrations found in this well likely originated from nearby agricultural activities. The slug input $(0.15 \mu \mathrm{g} / \mathrm{L}$ over 30 days $)$ is an approximation of the output from the Hydrus 1D vadose zone model. 


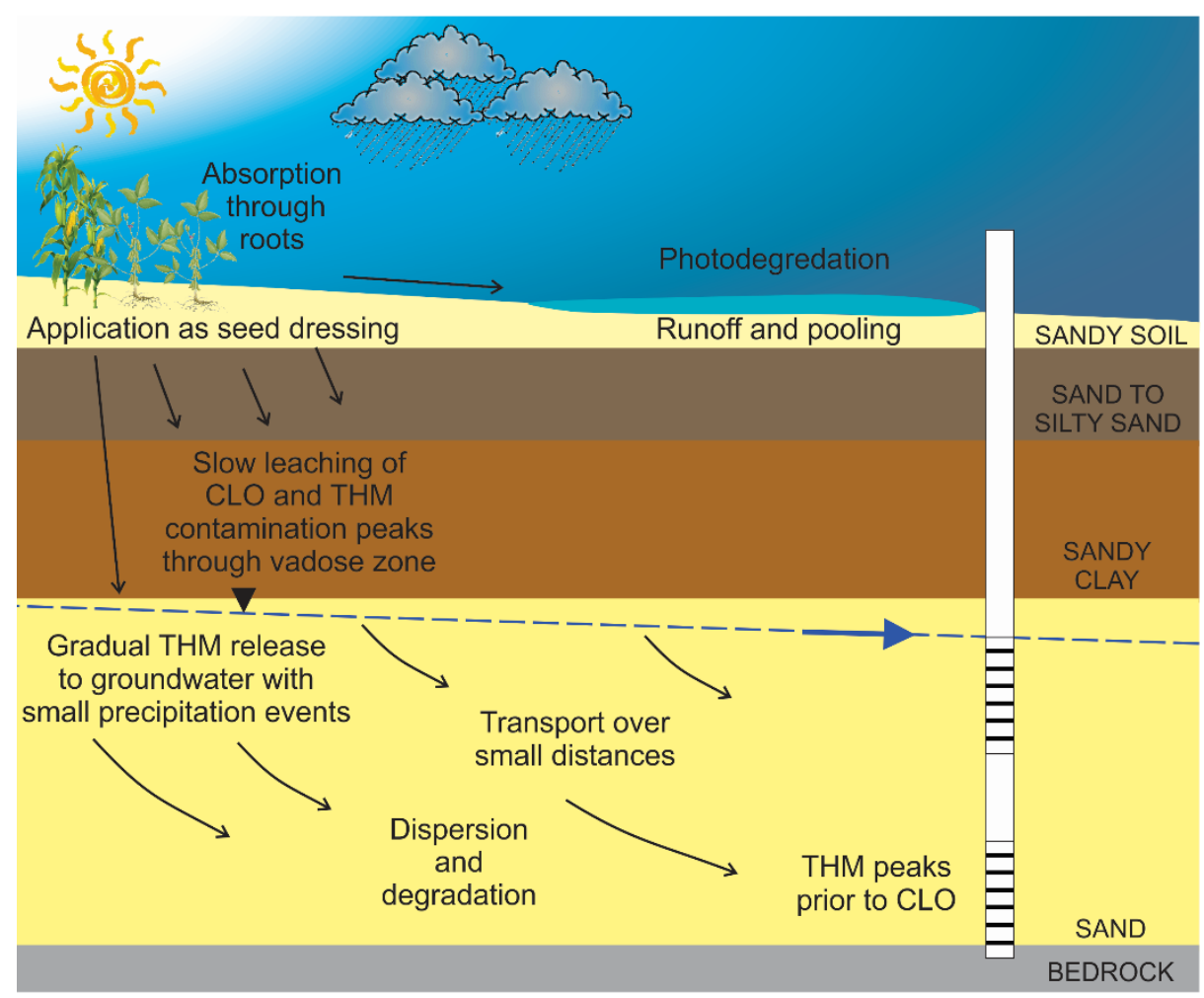

Figure 4.7: Conceptual model of clothianidin (CLO) and thiamethoxam (THM) movement through the unconfined, quaternary aquifer of Norfolk County. Mathematical modelling revealed that thiamethoxam is released gradually to the saturated zone before reaching a peak groundwater concentration. The peak thiamethoxam concentration occurs prior to that of clothianidin. The transport of both neonicotinoids is dominated by processes in the vadose zone where insignificant degradation occurs. Any concentrations of these contaminants that are found in groundwater are likely to originate from nearby agricultural activities.

In Lanark County, Hydrus 1D was used to simulate thiamethoxam transport through the $60 \mathrm{~cm}$ of overburden that exists above the bedrock at TW17; the analytical solution for one-dimensional advection with matrix diffusion was used to simulate transport through the fracture network. The Hydrus 1D simulation was run over 335 days between May 1, 2016 and March 31, 2017 (Table 4.7). The lower boundary condition was free drainage because the water table is between 1.5 and $2.5 \mathrm{~m}$ below the bottom of the overburden for the duration of the simulation. This lower boundary condition is appropriate for simulations that occur in the vadose zone (Šimůnek et al., 2013). Precipitation, runoff, and evapotranspiration were input as the upper boundary conditions (Figure 4.8). Evapotranspiration was calculated using the Penman-Montieth equation (Allen et al., 1998) with data obtained from Environment Canada (2017) and Stackhouse et al. (2015). Leaf area index (LAI) data were obtained from NASA Earth Observations (2017). It was difficult to simulate the delayed release of thiamethoxam from the overburden-a 50-day delay was only achieved after reducing the saturated hydraulic conductivity value to $0.8 \mathrm{~cm} /$ day. Further reductions in hydraulic conductivity caused the model to become unstable. The analytical solution for 
one-dimensional advection with matrix diffusion revealed that when thiamethoxam reaches crystalline bedrock it can be transported rapidly (on the order of days) through a fracture (Figure 4.9). This likely means that the soil with low permeability near TW17 governs the delayed release of thiamethoxam (Figure 4.10). This conclusion is consistent with the physical properties of thiamethoxam as the relatively low organic carbon-water partitioning coefficient and high solubility make it unlikely to adhere to permeable soil and probable to leach soon after application.

It is also possible that there are no fractures in the crystalline bedrock underneath the source agricultural field that are able to transport thiamethoxam. This would mean that the contaminant would have to move horizontally through the low permeability overburden before being reaching a fracture. It is feasible that this horizontal movement of the contaminant through the unsaturated overburden would delay release to groundwater until the spring freshet.

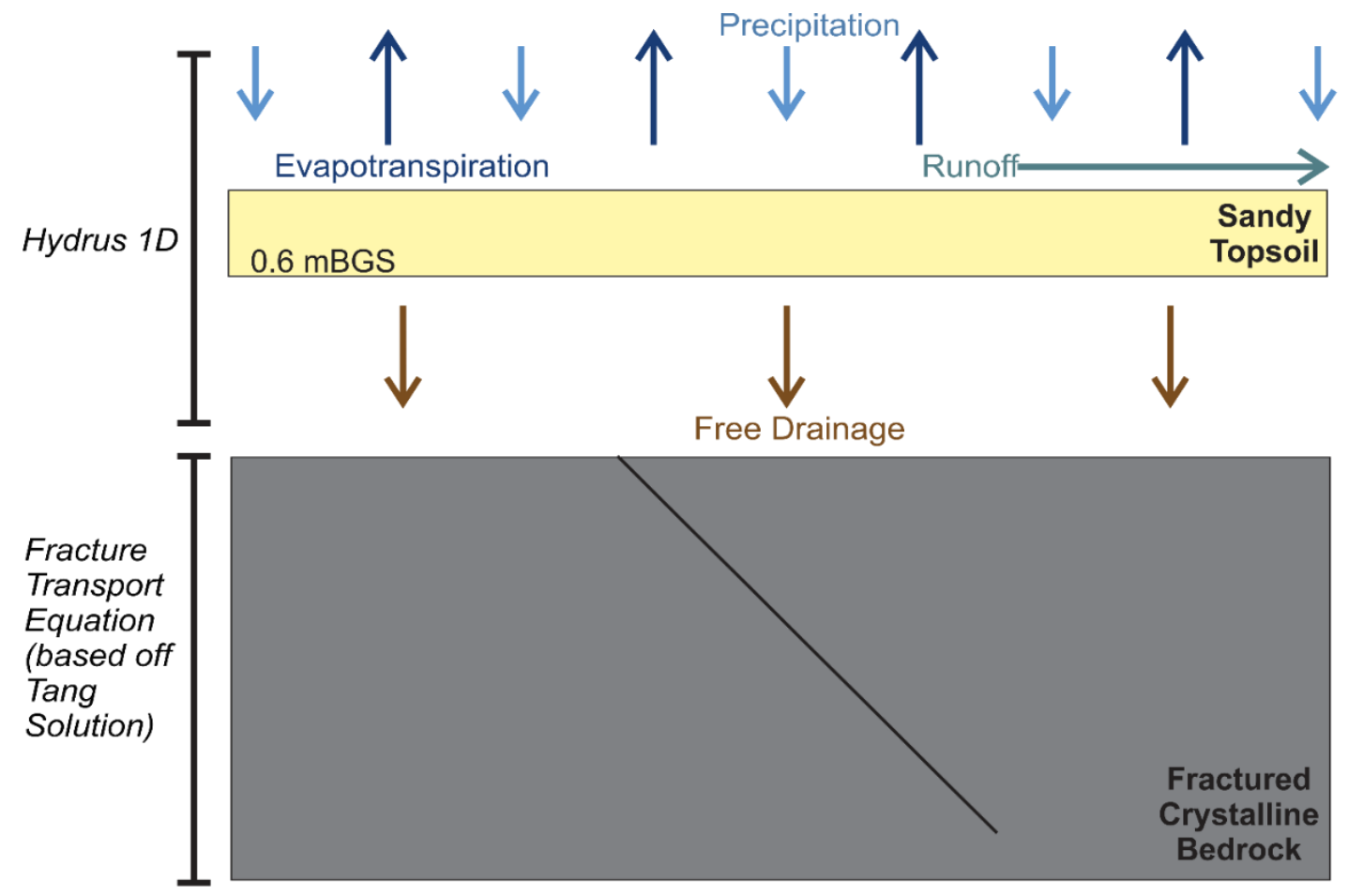

Figure 4.8: Conceptual diagram of the modelled 1D domain at TW17. In Hydrus 1D, precipitation, evapotranspiration, and runoff act as the upper boundary conditions, while free drainage is used as the lower boundary condition. The output from the Hydrus 1D model is used as an input to the analytical solution for one-dimensional advection with matrix diffusion (Sudicky, 1988; Sudicky and Frind, 1982). This fracture transport equation is adapted from the Tang solution (Tang et al., 1981). 


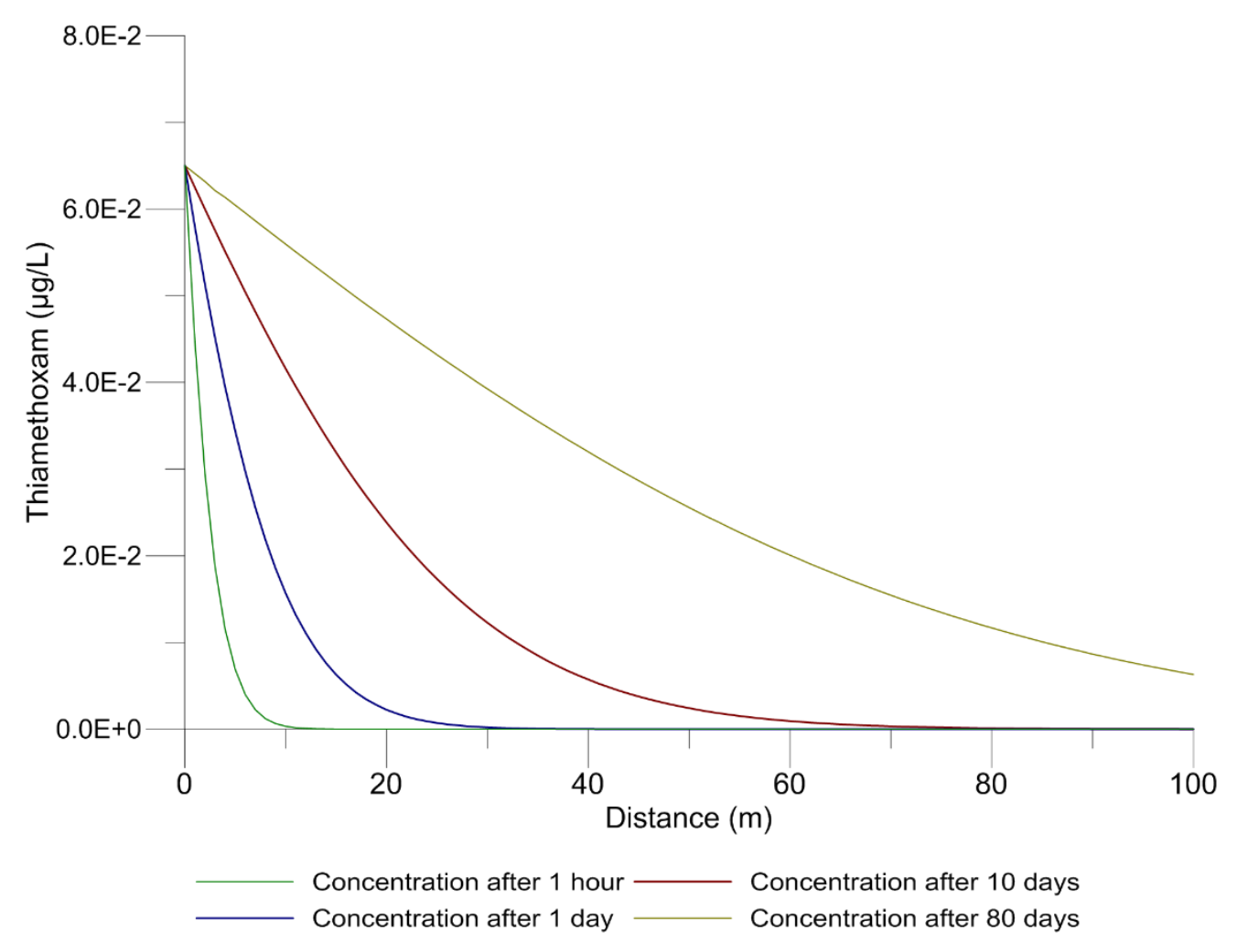

Figure 4.9: Breakthrough curves of thiamethoxam through a single fracture in Lanark County. These curves were calculated using the analytical solution for one-dimensional advection with matrix diffusion (Sudicky, 1988; Sudicky and Frind, 1982; Tang et al., 1981). The input concentration to this model was $0.065 \mu \mathrm{g} / \mathrm{L}$. These curves reveal that once thiamethoxam reaches a fracture, it can travel several meters within a few hours.

Table 4.9: Inputs to the analytical solution for one-dimensional advection with matrix diffusion. Fracture velocity was calculated according to the cubic law. There is minimal matrix diffusion in crystalline bedrock aquifers such as in the Tay River Watershed (Mutch et al., 1993). Fracture spacing was set at an unrealistically high number $\left(1.0 \times \mathbf{1 0}^{10}\right)$ in order to approximate flow through a single fracture.

\begin{tabular}{ccc}
\hline Parameter & Value & Source \\
\hline Source Concentration $(\mu \mathrm{g} / \mathrm{L})$ & 0.065 & Hydrus 1D unsaturated model \\
Fracture Aperture $(\mathrm{m})$ & $5.0 \times 10^{-4}$ & Praamsma (2016) \\
Fracture Gradient $(-)$ & 0.02 & Regional pressure transducer data \\
Velocity in Fracture $(\mathrm{m} / \mathrm{d})$ & 352 & Cubic Law (Witherspoon et al., 1980) \\
Fracture Dispersivity $(\mathrm{m})$ & 2.4 & Zhou et al. (2007) \\
Matrix Porosity (-) & 0.001 & Praamsma (2016) \\
Matrix and Fracture Retardation Factor $(-)$ & 1.0 & Praamsma (2016) \\
Diffusion Coefficient in Water (m²/d) & $3.89 \times 10^{-5}$ & Praamsma (2016) \\
Matrix Tortuosity $(-)$ & 0.1 & Praamsma (2016) \\
Contaminant Half-Life $(\mathrm{d})$ & 30.6 & Pesticide Properties Database (2017) \\
\hline
\end{tabular}




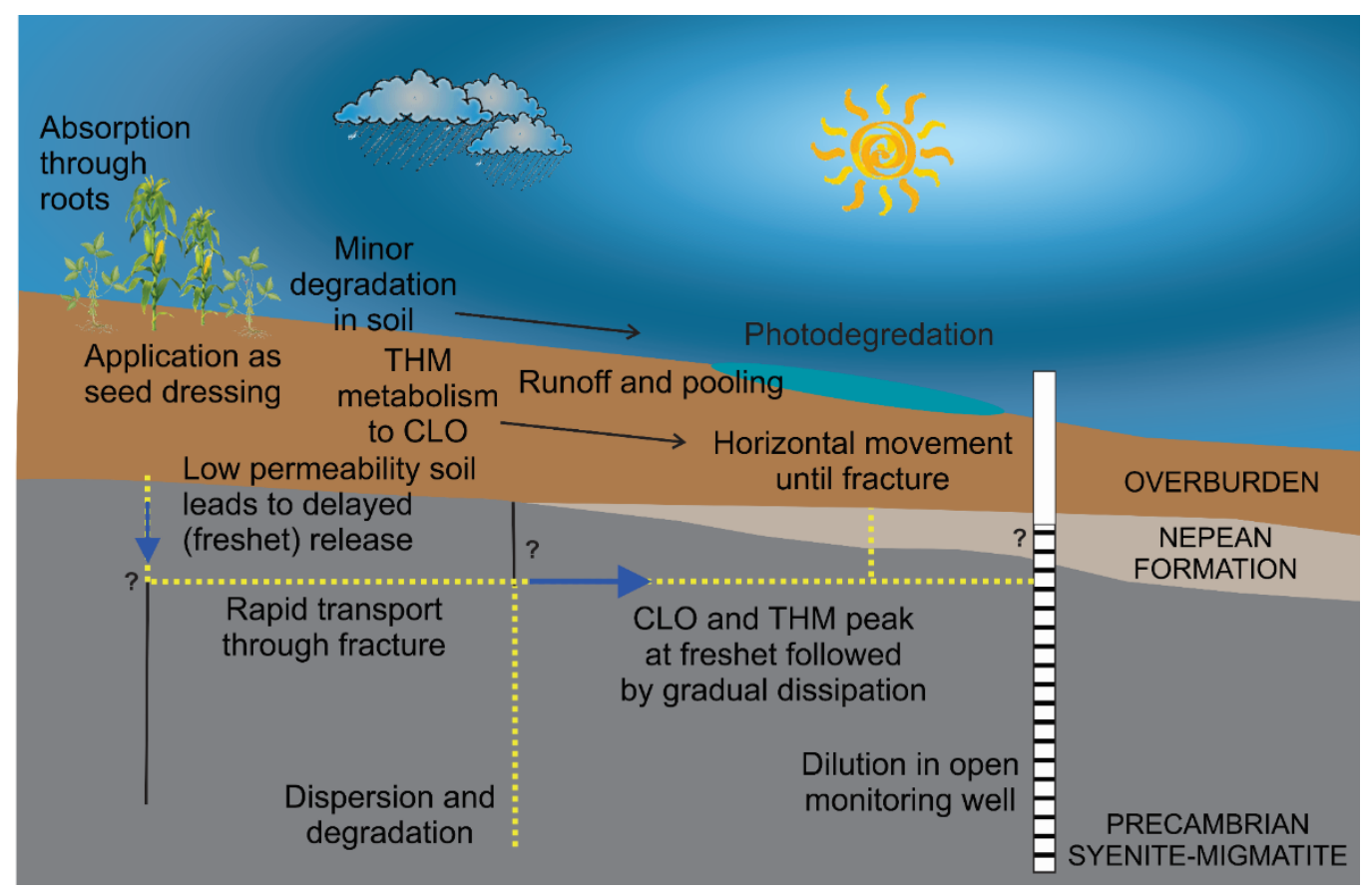

Figure 4.10: Conceptual model of clothianidin (CLO) and thiamethoxam (THM) transport to the fractured bedrock aquifer of Lanark County. Neonicotinoid movement through fractures is represented by the yellow dotted line. Due to the low permeability of the overburden near TW17, both neonicotinoids are relatively immobile in the topsoil until the high downward water flux associated with the spring freshet. The concentrations of both neonicotinoids are likely reduced through soil degradation over the 10 to 12 -month period prior to leaching. It is also possible that a portion of thiamethoxam is metabolized into clothianidin during this period. Once either neonicotinoid reaches a fracture, it are rapidly transported (on an order of days) through a fracture. It is likely that these neonicotinoids are further diluted due to the high volume of water in the $24 \mathrm{~m}$ open well.

These models were manipulated to give further insight into the movement of thiamethoxam and clothianidin in the subsurface. A sensitivity analysis revealed that the movement of neonicotinoids to groundwater is dependent on precipitation; increasing the precipitation by $15 \%$ causes an earlier release (approximately one month) of clothianidin and thiamethoxam from the Norfolk County unsaturated zone. However, there were only minor changes in the transport of both clothianidin and thiamethoxam when the hydraulic conductivity of each material in the Norfolk County model was adjusted by $15 \%$ (Appendix I - Sensitivity Analysis). However, the movement of thiamethoxam through the topsoil near TW17 was not affected by increased or decreased precipitation (Appendix I - Sensitivity Analysis). This is likely due to the thin overburden near that well.

The unsaturated Norfolk County model was also rerun using thiamethoxam as the input. Thiamethoxam was released from the vadose zone in the model at roughly the same time as clothianidin but at much lower concentrations and in a slightly more gradual fashion (Figure 4.11b). This may explain why thiamethoxam was not observed in Norfolk County groundwater- 
the gradual release could lead to low concentrations in groundwater that fall below the level of detection. Alternatively, the early release of thiamethoxam could mean that the sampling regime missed any thiamethoxam peak that occurred in Norfolk County. It is also possible that the relatively rapid rate of thiamethoxam degradation in the soil medium (compared to that of clothianidin) results in lower thiamethoxam concentrations reaching the saturated subsurface (Table 4.1). Inversely, clothianidin release from the TW17 Hydrus model was almost identical to that of thiamethoxam (Figure 4.11c). This strengthens the argument that the delayed release of thiamethoxam at TW17 is a function of the unusually low permeability overburden at this location.

Manipulations to the modelled parameters also revealed that the modelled clothianidin concentrations at the groundwater table did not equal those observed at LP-MW-02 until the source concentration was increased by an order of seven (Appendix I - Sensitivity Analysis), which confirms that the source concentrations used in these models were likely underestimated. Within 30 days, that concentration would travel a distance of $10 \mathrm{~m}$ from the groundwater table through the saturated subsurface before dissipating at greater distances. Additionally, in order for the clothianidin peak to travel $100 \mathrm{~m}$ in the saturated porous media at concentrations equal to what was detected in groundwater at LP-MW-02D (calculated with the Ogata-Banks solution using outputs from Hydrus 1D), the contaminant input to the Hydrus 1D model would need to be increased by an order of 9 (Appendix I - Sensitivity Analysis). This high input concentration supports the argument that clothianidin found in groundwater likely originates from nearby agricultural activities. Overall, these models also revealed that the transport of both clothianidin and thiamethoxam to groundwater is dominated by processes occurring in the vadose zone (Figure 4.11d). 
A)

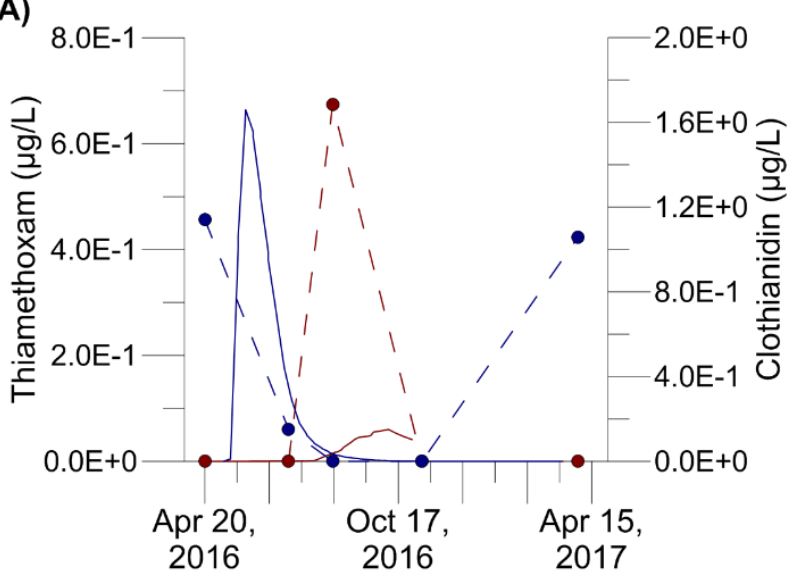

C)

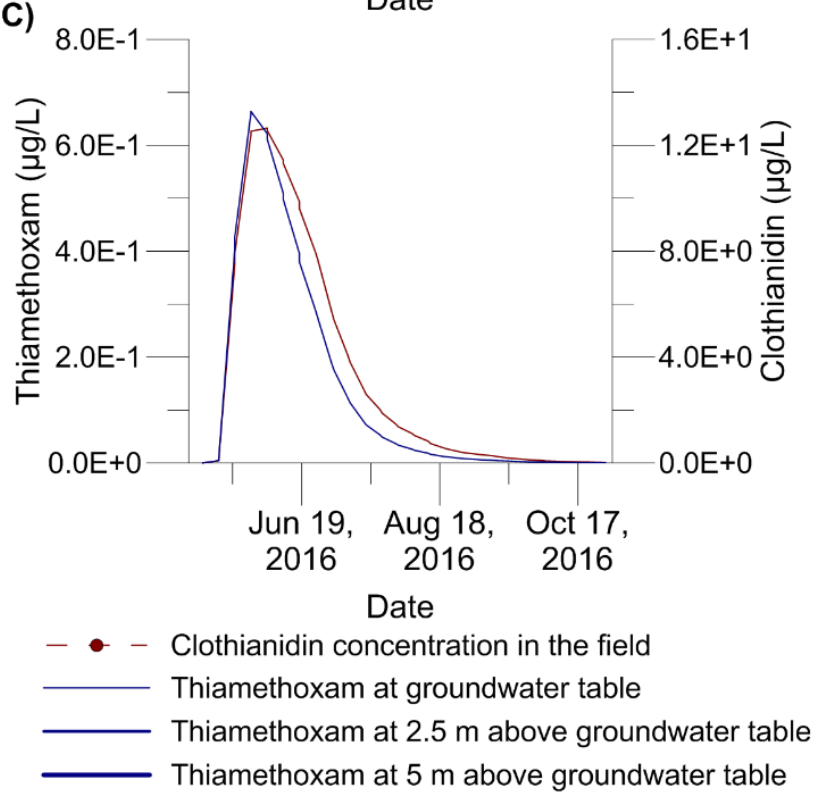

B)

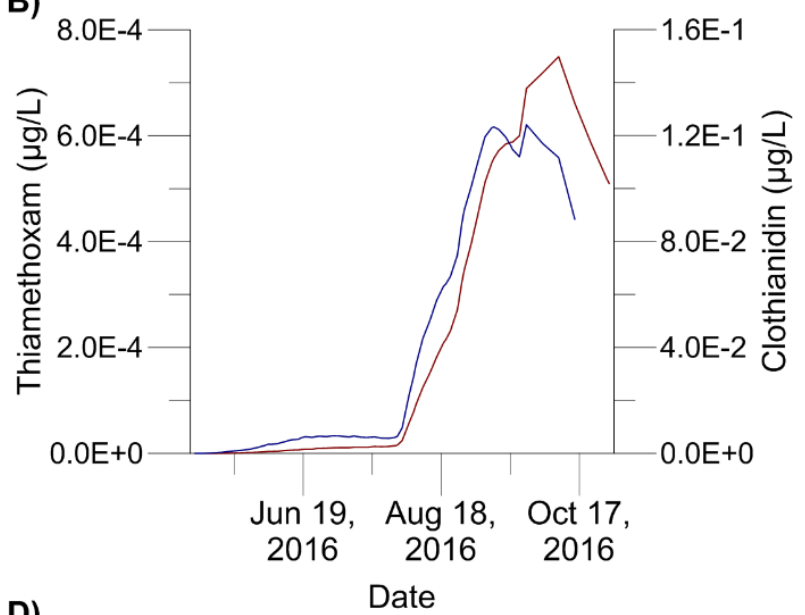

D)

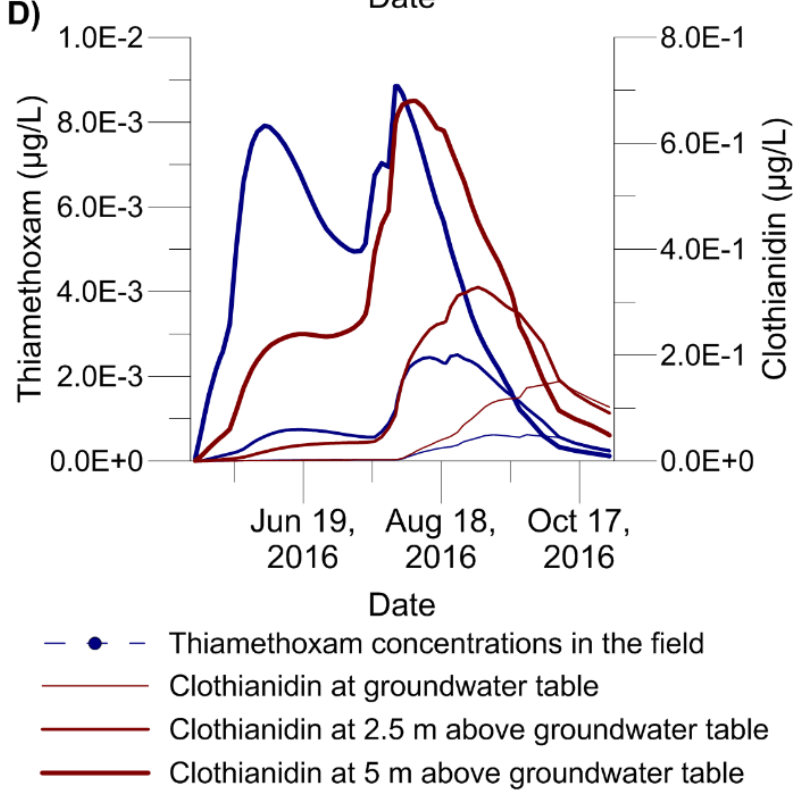

Figure 4.11: Hydrus 1D graphical outputs from LP-MW-02 and TW17.

A) The field detections for clothianidin (LP-MW-02D) and thiamethoxam (TW17) are contrasted with the modelled concentrations for those same wells. The modelled clothianidin peak at the groundwater table occurs roughly one month after the field peak in groundwater. Model simulations were unable to reproduce the freshet thiamethoxam peak that occurred at TW17.

B) Clothianidin and thiamethoxam concentrations at the groundwater table at LP-MW-02. Thiamethoxam appears to be released in a similar, but more gradual manner than clothianidin at this location. This may result in thiamethoxam concentrations that fall below the LOQ in the field.

C) Clothianidin and thiamethoxam concentrations at the groundwater table at TW17. The small domain $(0.6 \mathrm{~m})$ results in a similar release of both neonicotinoids at this location.

D) The transport of clothianidin and thiamethoxam at LP-MW-02 at the groundwater table, $2.5 \mathrm{~m}$ above the groundwater table, and $5 \mathrm{~m}$ above the groundwater table. The peak magnitude of both neonicotinoids decreases by half with each depth increase.

\subsubsection{Toxicological Information}

Peak concentrations of clothianidin, imidacloprid, and thiamethoxam that were found in the groundwater sampling regime were compared to toxicological endpoints (both acute and chronic) for honeybees, bumblebees, solitary bees, and aquatic invertebrates (Table 4.10). This was done 
because groundwater can come into contact with honeybee, bumblebee, solitary bee, and aquatic invertebrate species through springs and domestic/municipal groundwater pumping systems (this could occur through groundwater-fed irrigation). It was revealed that all neonicotinoid concentrations found in groundwater in this study are not of concern to the heath of any of these species. In fact, maximum concentrations are at least an order of magnitude lower than what would be considered harmful to these species.

Table 4.10: Toxicological endpoints are shown against the maximum concentrations of clothianidin, imidacloprid, and thiamethoxam that were detected in groundwater. Unless otherwise noted, all acute and chronic endpoints for honeybees, bumblebees, and solitary bees are 48 h LD50 and $10 \mathrm{~d}$ LD50 values, respectively. All aquatic invertebrate acute and chronic toxicological endpoints are $48 \mathrm{~h}$ EC50 and $21 \mathrm{~d}$ NOEC values, respectively. Maximum exposure rates for honeybees, bumblebees, and solitary bees are calculated assuming a maximum water consumption of $11 \mu \mathrm{L}$ of water at $35^{\circ} \mathrm{C}$ (Free and Spencer-Booth, 1958) with maximum neonicotinoid concentrations found in the field. This table is based on information found in European Food Safety Authority (2016a, 2016b, 2015) and Pesticide Properties Database (2017).

\begin{tabular}{|c|c|c|c|c|c|}
\hline Neonicotinoid & $\begin{array}{l}\text { Toxicological } \\
\text { Endpoint }\end{array}$ & $\begin{array}{l}\text { Honeybees } \\
\text { ( } \mu \mathrm{g} \text { a.i./bee) }\end{array}$ & $\begin{array}{l}\text { Bumblebees } \\
\text { ( } \mu \mathrm{g} \text { a.i./bee) }\end{array}$ & $\begin{array}{l}\text { Solitary Bees } \\
\text { ( } \mu \text { g a.i./bee) }\end{array}$ & $\begin{array}{c}\text { Aquatic } \\
\text { Invertebrates } \\
(\mathrm{mg} / \mathrm{L})\end{array}$ \\
\hline \multirow{3}{*}{ Clothianidin } & Acute & $3.79 \times 10^{-3}$ & $1.91 \times 10^{-3}$ & $3.79 \times 10^{-4}$ & $>40$ \\
\hline & Chronic & $1.38 \times 10^{-3}$ & $1.38 \times 10^{-4}$ & $1.38 \times 10^{-4}$ & 0.12 \\
\hline & $\begin{array}{l}\text { Maximum } \\
\text { Exposure }\end{array}$ & \multicolumn{3}{|c|}{$2.30 \times 10^{-5}$} & $2.09 \times 10^{-3}$ \\
\hline \multirow{3}{*}{ Imidacloprid } & Acute & $3.79 \times 10^{-3}$ & $3.8 \times 10^{-2 \star}$ & $3.7 \times 10^{-4}$ & 85 \\
\hline & Chronic & $>2.82 \times 10^{-3}$ & $>2.82 \times 10^{-4}$ & $>2.82 \times 10^{-4}$ & 1.8 \\
\hline & $\begin{array}{l}\text { Maximum } \\
\text { Exposure }\end{array}$ & \multicolumn{3}{|c|}{$7.70 \times 10^{-7}$} & $0.07 \times 10^{-3}$ \\
\hline \multirow{3}{*}{ Thiamethoxam } & Acute & $5.0 \times 10^{-3}$ & $5.0 \times 10^{-3}$ & $5.0 \times 10^{-4}$ & $>100$ \\
\hline & Chronic & $\mathrm{N} / \mathrm{A}$ & $\mathrm{N} / \mathrm{A}$ & $\mathrm{N} / \mathrm{A}$ & $>100$ \\
\hline & $\begin{array}{l}\text { Maximum } \\
\text { Exposure }\end{array}$ & \multicolumn{3}{|c|}{$5.06 \times 10^{-6}$} & $0.46 \times 10^{-3}$ \\
\hline
\end{tabular}

\subsection{Summary and Conclusions}

A groundwater monitoring program was conducted between April 2016 and April 2017 in order to investigate the presence and fate of neonicotinoids in groundwater. This research was conducted at two distinct hydrogeological locations: in the sandy, unconfined aquifer of Norfolk County and the fractured bedrock aquifer of Lanark County. Crop data and a farmer survey revealed that the main neonicotinoids used in the two regions were clothianidin and thiamethoxam. Imidacloprid is also used on a smaller scale and was detected twice (in July 2016 and August 2016) at concentrations marginally above the level of quantitation. Clothianidin was found at three wells in Norfolk County and one well in Lanark County during the August 2016 sampling round. All thiamethoxam detections occurred in one well (TW17) during the two spring freshet sampling 
rounds. This late thiamethoxam peak was attributed to a low permeability overburden which delayed the release of that contaminant to groundwater. Mathematical modelling exercises found that clothianidin and thiamethoxam are likely transported to groundwater as a pulse. This aligns with the field data; however, more frequent sampling rounds should be conducted near neonicotinoid peaks to validate the theory that neonicotinoids move to groundwater in a pulse.

Overall, clothianidin and thiamethoxam were observed at low concentrations in groundwater throughout agriculturally-intensive Norfolk County and the vulnerable groundwater of Lanark County. All groundwater concentrations were at least an order of magnitude lower than what is considered harmful to honeybee, bumblebee, solitary bee, and aquatic invertebrate species. These samples were taken during the time period in which neonicotinoid use was being phased out by the Government of Ontario (Government of Ontario, 2009). The farmer survey revealed that there was only a minor reduction of agricultural neonicotinoid use in 2016; neonicotinoid use will decline dramatically in 2017 and 2018 due to the increasing availability of insecticide alternatives. Maize crops will predominantly use fungicide seed coatings in 2017, while it is expected that many soybean crops will use neonicotinoid seed coatings in 2017. The fungicide replacement for soybean seed coatings will be in place during the 2018 season in Ontario. The low presence of neonicotinoids in groundwater combined with this ongoing phase-out makes future research into this topic untenable within Ontario. Additionally, the modelling and interpretation portion of this study did not focus on imidacloprid due to the low concentrations found in groundwater. Future studies could build on past research into the presence of imidacloprid in Canadian groundwater resources (Giroux, 2003; Giroux and Sarrasin, 2011); however, such research would be contingent on the proposal by the Canadian Pest Management Regulatory Agency to phase-out the use of imidacloprid within three to five years (PMRA, 2016a).

If future studies into the toxicity of neonicotinoids on non-target organisms find that they can be negatively impacted by clothianidin or thiamethoxam at concentrations that have been observed in groundwater, further research should be performed on the probability of contaminated groundwater coming into contact with these organisms.

Overall, the main conclusions from this study about the presence and fate of neonicotinoids in groundwater are as follows:

1. The transport of clothianidin and thiamethoxam are dominated by processes which occur in the vadose zone. When either neonicotinoid reaches groundwater, it can move significant distances within an order of weeks in an unconfined sandy aquifer. They 
move rapidly (on the order of hours) within a fractured, crystalline bedrock aquifer system.

2. The delayed release of thiamethoxam that occurred at one location in Lanark County was likely due to the relatively low permeability overburden; neonicotinoids can be retained in these types of high risk soils at low concentrations. Mathematical modelling suggests that thiamethoxam can be released from topsoil prior to and in a slightly more gradual manner than clothianidin under similar environmental conditions.

3. Field studies show that neonicotinoids appear to follow an annual cycle with peaks in the late summer into autumn. Mathematical modelling revealed that clothianidin and thiamethoxam appear to occur as a pulse in groundwater. Further field studies should be performed to validate this modelling output. These studies should involve more regular sampling rounds (bi-weekly would likely be sufficient) between late July into early September.

4. Further research into how neonicotinoids move in groundwater within different climatic settings and hydrogeologic settings is recommended. Future studies could also analyze the effects of crop rotations on neonicotinoid movement.

5. Several neonicotinoids are not registered for use in Ontario but are used throughout the United States and many countries in the southern hemisphere. Further research should be conducted to analyze the movement of acetamiprid, dinotefuran, nitenpyram, and thiacloprid to groundwater.

6. While future research into the movement of neonicotinoids to Ontario groundwater is likely untenable due to the ongoing phase-out of these compounds, subsequent studies could focus on the presence and fate of any insecticides in groundwater that will be used in lieu of neonicotinoids.

\section{Acknowledgements}

This research was supported by the OMAFRA-University of Guelph Partnership and the Ontario Federation of Agriculture. The authors acknowledge Norfolk County and Chris Miller for providing access to monitoring wells. Thank you also to farmers/landowners in Norfolk and Lanark Counties who provided information about their land use practices. Thank you to Laura Perron, Heather Shilton, and Peter Bishop for help with field work and generating maps. 


\subsection{References}

Agriculture and Agri-Food Canada, 2017. AAFC Crop Type Feature Catalog.

Allen, R.G., Pereira, L.S., Raes, D., Smith, M., 1998. Crop Evapotranspiration - Guidelines for Computing Crop Water Requirements. Rome. doi:10.1016/j.eja.2010.12.001

Anderson, Dubetz, C., Palace, V.P., 2015. Neonicotinoids in the Canadian aquatic environment: A literature review on current use products with a focus on fate, exposure, and biological effects. Sci. Total Environ. doi:10.1016/j.scitotenv.2014.09.090

Armstrong, T.R., Carter, D.K., 2010. The subsurface Paleozoic stratigraphy of southern Ontario.

Bacey, J., 2000. Environmental Fate of Imidacloprid. Sacramento.

Bergin, R., Nordmark, C., 2009. GW 09: Ground Water Monitoring for Imidacloprid and Four Degradates in High Use Areas in California.

Bonmatin, J.M., Giorio, C., Girolami, V., Goulson, D., Kreutzweiser, D.P., Krupke, C., Liess, M., Long, E., Marzaro, M., Mitchell, E.A., Noome, D.A., Simon-Delso, N., Tapparo, A., 2015. Environmental fate and exposure; neonicotinoids and fipronil. Environ. Sci. Pollut. Res. 22, 3567. doi:10.1007/s11356-014-3332-7

Bortoluzzi, E.C., Rheinheimer, D.S., Gonçalves, C.S., Pellegrini, J.B.R., Maroneze, A.M., Kurz, M.H.S., Bacar, N.M., Zanella, R., 2007. Investigation of the occurrence of pesticide residues in rural wells and surface water following application to tobacco. Quim. Nova 30, 1872-1876. doi:10.1590/S0100-40422007000800014

Bowles, J.E., 1992. Engineering Properties of Soils and their Measurement, 4th ed. Irwin McGraw-Hill, Boston, MA.

Browne, D., Levison, J., Limay-Rios, V., Novakowski, K., 2017. A Review of the Presence and Fate of Neonicotinoids in the Environment with a Focus on Groundwater. Submitt. to Water Qual. Res. J. Canada.

Canadian Council of Ministers of the Environment, 2007. Canadian Water Quality Guidelines for the Protection of Aquatic Life - Imidacloprid. Can. Environ. Qual. Guidel.

Chapman, L.J., Putnam, D.F., 1984. The physiography of southern Ontario, 3rd ed.; 3.

Craig, J.R., 2014. Ogata-Banks 1D Transport Solution. 
Department of Environmental Conservation, 2014. Long Island Pesticide Pollution Prevention Strategy.

Domenico, P.A., Schwartz, F.W., 1990. Physical and Chemical Hydrogeology. John Wiley \& Sons, Inc., New York.

Environment and Climate Change Canada, 2017. Historical Data [WWW Document]. URL http://climate.weather.gc.ca/historical_data/search_historic_data_e.html (accessed 6.1.17).

US EPA, 1996. Soil Screening Guidance: User's Guide. Washington, D.C.

European Commission, 2013. Bee Health: EU-wide restrictions on Pesticide use to enter into force on 1 December, Europa Press Release Database. Brussels.

European Food Safety Authority, 2016a. Peer review of the pesticide risk assessment for the active substance clothianidin in light of confirmatory data submitted. EFSA J. 14. doi:10.2903/j.efsa.2016.4606

European Food Safety Authority, 2016b. Peer review of the pesticide risk assessment for the active substance imidacloprid in light of confirmatory data submitted. EFSA J. 14. doi:10.2903/j.efsa.2016.4607

European Food Safety Authority, 2015. Conclusion on the peer review of the pesticide risk assessment for bees for the active substance thiamethoxam considering all uses other than seed treatments and granules. EFSA J. 13, 4211. doi:10.2903/j.efsa.2015.4211

Felsot, A., 2001. Imidacloprid: Insecticide on the Move. Agrichem. Environ. News Index.

Forero, L.G., 2017. Concentration and Off-target Movement of Neonicotinoid Residues During Agricultural Practices in Southwestern Ontario by CONCENTRATION AND OFF-TARGET MOVEMENT OF NEONICOTINOID RESIDUES DURING AGRICULTURAL PRACTICES.

Fossen, M., 2006. Environmental Fate of Imidacloprid. Regulation 1-16.

Free, J.B., Spencer-Booth, Y., 1958. Observations on the Temperature Regulation and Food Consumption of Honeybees (Apis mellifera). J. Exp. Biol. 35, 930-937.

Gardner, S.G., 2017. Groundwater Nitrate in Three Hydrogeologic Settings throughout Southwestern Ontario. University of Guelph.

Gelhar, L.W., Welty, C., Rehfeldt, K.R., 1992. A Critical Review of Data on Field-Scale Dispersion in Aquifers. Water Resour. Res. 28, 1955-1974. 
Girolami, V., Mazzon, L., Squartini, a, Mori, N., Marzaro, M., Di Bernardo, a, Greatti, M., Giorio, C., Tapparo, a, 2009. Translocation of neonicotinoid insecticides from coated seeds to seedling guttation drops: a novel way of intoxication for bees. J. Econ. Entomol. 1808-1815. doi:10.1603/029.102.0511

Giroux, I., 2014. Présence de pesticides dans l'eau au Québec- Zones de vergers et de pommes de terre, 2010 à 2012. Québec.

Giroux, I., 2003. Contamination de l'eau souterraine par les pesticides et les nitrates dans les régions en culture de pommes de terre, Campagnes d'Echantillonage.

Giroux, I., Sarrasin, B., 2011. Pesticides et nitrates dans l'eau souterraine près de cultures de pommes de terre - Échantillonnage dans quelques régions du Québec en 2008 et 2009.

Gleeson, T., Novakowski, K., 2009. Identifying watershed-scale barriers to groundwater flow: Lineaments in the Canadian shield. Bull. Geol. Soc. Am. 121, 333-347. doi:10.1130/B26241.1

Gleeson, T., Novakowski, K., Cook, P.G., Kyser, T.K., 2009a. Constraining groundwater discharge in a large watershed: Integrated isotopic, hydraulic, and thermal data from the Canadian shield. Water Resour. Res. 45. doi:10.1029/2008WR007622

Gleeson, T., Novakowski, K., Kurt Kyser, T., 2009b. Extremely rapid and localized recharge to a fractured rock aquifer. J. Hydrol. 376, 496-509. doi:10.1016/j.jhydrol.2009.07.056

Godfray, Blacquière, T., Field, L.M., Hails, R.S., Petrokofsky, G., Potts, S.G., Raine, N.E., Vanbergen, a. J., McLean, a. R., 2014. A restatement of the natural science evidence base concerning neonicotinoid insecticides and insect pollinators. Proc. R. Soc. B Biol. Sci. 281, 20140558. doi:10.1098/rspb.2014.0558

Goulson, D., 2014. Pesticides linked to bird declines. Nature 511, 295-296. doi:10.1038/nature13642

Goulson, D., 2013. An overview of the environmental risks posed by neonicotinoid insecticides. J. Appl. Ecol. 50, 977-987. doi:10.1111/1365-2664.12111

Government of Ontario, 2009. Ontario Pesticide Act. Canada.

Gupta, S., Gajbhiye, V.T., Agnihotri, N.P.K., 2002. Leaching behaviour of imidacloprid formulations in soil, Bull. Environ. Contam. Toxicol. 68, 502-508. doi:10.1007/s00128-001-02838 
Hladik, M., Kolpin, D.W., Kuivila, K.M., 2014. Widespread occurrence of neonicotinoid insecticides in streams in a high corn and soybean producing region, USA. Environ. Pollut. 193, 189-196. doi:10.1016/j.envpol.2014.06.033

Hollingham, M., 2011. Sources of elevated nitrate concentrations in municipal groundwater supplies in Norfolk and Oxford Counties. University of Waterloo.

Hoskin Scientific, 2017. HOBO Rain Gauge Data Logger [WWW Document]. URL https://shoponset.hoskin.ca/products/hobo-rain-gauge-data-logger (accessed 6.29.17).

Huseth, A.S., Groves, R.L., 2014. Environmental fate of soil applied neonicotinoid insecticides in an irrigated potato agroecosystem. PLoS One 9. doi:10.1371/journal.pone.0097081

Kettles, I.M., 1992. Surficial Geology, A Series Map, Report 1800A. Perth, ON.

Kurwadkar, S., Dewinne, D., Wheat, R., McGahan, D.G., Mitchell, F.L., 2013. Time dependent sorption behavior of dinotefuran, imidacloprid and thiamethoxam. J. Environ. Sci. Health. B. 48, 237-42. doi:10.1080/03601234.2013.742412

Lamers, M., Anyusheva, M., La, N., Nguyen, V.V., Streck, T., 2011. Pesticide Pollution in Surfaceand Groundwater by Paddy Rice Cultivation: A Case Study from Northern Vietnam. Clean - Soil, Air, Water 39, 356-361. doi:10.1002/clen.201000268

Levison, J., Novakowski, K., 2009. The impact of cattle pasturing on groundwater quality in bedrock aquifers having minimal overburden. Hydrogeol. J. 17, 559-569. doi:10.1007/s10040008-0385-z

Levison, J., Novakowski, K., Reiner, E.J., Kolic, T., 2012. Potential of groundwater contamination by polybrominated diphenyl ethers (PBDEs) in a sensitive bedrock aquifer (Canada). Hydrogeol. J. 20, 401-412. doi:10.1007/s10040-011-0813-3

Levison, J.K., Novakowski, K.S., 2012. Rapid transport from the surface to wells in fractured rock: A unique infiltration tracer experiment. J. Contam. Hydrol. 131, 29-38. doi:10.1016/j.jconhyd.2012.01.001

LPRCA, 2008. Long Point Region Watershed Characterization Report. Toronto.

Macdonald, G.D., 2015. Developing Novel Techniques for Measuring In Situ Groundwater Nitrate Concentrations, Vertical Geochemical Profiling, and Real-time Remote Groundwater Quality Monitoring. University of Guelph. 
Maienfisch, P., Angst, M., Brandl, F., Fischer, W., Hofer, D., Kayser, H., Kobel, W., Rindlisbacher, A., Senn, R., Steinemann, A., Widmer, H., 2001. Chemistry and biology of thiamethoxam: A second generation neonicotinoid. Pest Manag. Sci. 57, 906-913. doi:10.1002/ps.365

Marich, A.S., 2010. An Assessment of Subsurface Sediments in the Central Norfolk Sand Plain; Norfolk and Oxford Counties, Southern Ontario, Groundwater Resources Study 14. Ontario Geological Survey.

Matrix Solutions Inc., 2015. Long Point Region Tier Three Water Budget and Local Area Risk Assessment. Waterloo.

Matrix Solutions Inc., 2014. Long Point Region Tier Three Water Budget and Local Area Risk Assessment Appendix B: Model Development and Calibration Report. Waterloo.

Milloy, C.A., 2007. Measurement of Hydraulic Head for the Evaluation fo Groundwater Recharge to Discrete Fracture Zones in a Crystalline Bedrock Aquifer. Queen's University.

Miranda, G.R.B., Raetano, C.G., Silva, E., Daam, M. a., Cerejeira, M.J., 2011. Environmental Fate of Neonicotinoids and Classification of Their Potential Risks to Hypogean, Epygean, and Surface Water Ecosystems in Brazil. Hum. Ecol. Risk Assess. An Int. J. 17, 981-995. doi:10.1080/10807039.2011.588159

Morrissey, C.A., Mineau, P., Devries, J.H., Sanchez-Bayo, F., Liess, M., Cavallaro, M.C., Liber, K., 2015. Neonicotinoid contamination of global surface waters and associated risk to aquatic invertebrates: A review. Environ. Int. doi:10.1016/j.envint.2014.10.024

Mutch, R.D., Scott, J.I., Wilson, D.J., 1993. Cleanup of Fractured Rock Aquifers: Implications of Matrix Diffusion. Environ. Monit. Assess. 24, 45-70.

NASA Earth Observations, 2017. Leaf Area Index (8 Day - Terra/MODIS) [WWW Document]. URL https://neo.sci.gsfc.nasa.gov/view.php?datasetld=MOD15A2_E_LAI\&year=2016 (accessed 7.10.17).

Ogata, A., Banks, R.B., 1961. A Solution of the Differential Equation of Longitudinal Dispersion in Porous Media, Professional Paper 411-A. Washington, D.C.

OMAFRA, 2016. Field Crop Protection Guide 2016-2017, 812. Guelph.

Ontario Geological Survey, 2010. Surficial Geology of Southern Ontario.

Pesticide Properties Database, 2017. Clothianidin. 
PMRA, 2016. Imidacloprid - Proposed Re-Evaluation Decision. Ottawa.

Praamsma, T., Novakowski, K., Kyser, K., Hall, K., 2009. Using stable isotopes and hydraulic head data to investigate groundwater recharge and discharge in a fractured rock aquifer. $J$. Hydrol. 366, 35-45. doi:10.1016/j.jhydrol.2008.12.011

Praamsma, T.W., 2016. Rock Outcrops in the Canadian Shield: An Investigation of Contaminant Transport from Surface Sources in Fractured Rock Aquifers. Queen's University.

Saleem, S.R., Levison, J., Parker, B., Martin, R.C., 2016. Development of a Field-Scale Model to Simulate Nitrate Transport in Groundwater from Agricultural Lands, in: The Geological Society of America Joint 52nd Northeastern Annual Section. Pittsburgh.

Satlantic, 2017. SUNA [WWW Document]. URL http://satlantic.com/suna Savard, (accessed 6.29.17).

Schaafsma, A., Limay-Rios, V., Baute, T., Smith, J., Xue, Y., 2015. Neonicotinoid insecticide residues in surface water and soil associated with commercial maize (corn) fields in Southwestern Ontario. PLoS One 10, 1-21. doi:10.1371/journal.pone.0118139

Schaafsma, A., Limay-Rios, V., Xue, Y., Jiang, Y., Forero, L.G., 2017. Neonicotinoid insecticide residues in subsurface drainage and open ditch water around maize fields in southwestern Ontario, Canada. Chemosph. Press.

Schaafsma, A., Limay-Rios, V., Xue, Y., Smith, J., Baute, T., 2016. Field-scale examination of neonicotinoid insecticide persistence in soil as a result of seed treatment use in commercial maize (corn) fields in southwestern Ontario. Environ. Toxicol. Chem. 35, 295-302. doi:10.1002/etc.3231

Schaap, M., Brown, G.E., 2003. Rosetta Lite.

Sheets, L.P., 2010. Imidacloprid: A Neonicotinoid Insecticide. Hayes' Handb. Pestic. Toxicol. 2055-2064. doi:10.1016/B978-0-12-374367-1.00095-1

Šimůnek, J., Sejna, M., van Genuchten, M.T., 2013. Code for Simulating the One-Dimensional Movement of Water, Heat, and Multiple Solutes in Variabe Saturated Porous Media.

Smith, R.T., Atkinson, K., 1975. Techniques in pedology: a handbook for environmental and resource studies. Elek Science, London, England.

Solinst Canada Ltd., 2015. Levelogger Series Quick Start Guide. Georgetown, Ontario. 
Stackhouse, P.W., Westberg, D., Hoell, J.M., Chandler, W.S., Zhang, T., 2015. Prediction Of Worldwide Energy Resource - Agroclimatology Methodology.

Sudicky, E.A., 1988. CRAFLUSH, Programmer's Guide.

Sudicky, E.A., Frind, E.O., 1982. Contaminant transport in fractured porous media: Analytical solutions for a system of parallel fractures. Water Resour. Res. 18, 1634-1642.

Syngenta Canada Inc., 2016. Cruiser Maxx $®$ Pesticide Label. Guelph, ON.

Tang, D.H., Frind, E.O., Sudicky, E.A., 1981. Contaminant transport in fractured porous media: Analytical solution for a single fracture. Water Resour. Res. 17, 555-564.

Trimper, S.A., 2010. The Presence and Transport of Human Enteric Viruses in Fractured Bedrock Aquifers. Queen's University.

Van Genuchten, M.T., 1981. Analytical solutions for chemical transport with simultaneous adsorption, zero-order production and first-order decay. J. Hydrol. 49, 213-233. doi:10.1016/0022-1694(81)90214-6 


\section{Conclusion and Recommendations}

The purpose of this research was to quantify the presence and fate of neonicotinoids in two distinct Ontario aquifers: the sandy, unconfined aquifer in Norfolk County and the fractured, crystalline bedrock aquifer of Lanark County. This involved a seasonal groundwater sampling regime and subsequent mathematical modelling to determine the environmental parameters that influence the movement of neonicotinoids to groundwater.

This research included five sampling rounds at both research sites between 2016 and 2017 sampling occurred in April 2016, July 2016, August 2016, November 2016, and April 2017. The April sampling occurred during the spring freshet, the July and August sampling took place between seed sowing and crop harvesting, while the November sampling occurred during soybean and corn harvesting. Additionally, soil sampling occurred in July 2016 to link surficial neonicotinoid concentrations to those found in groundwater.

Between 18 and 26 monitoring intervals were sampled at each site during every sampling round (Appendix B - Raw Sampling Data). For each sample that was taken, a calibrated YSI 556 handheld instrument measured temperature, dissolved oxygen, electrical conductivity, and oxidation-reduction potential (ORP). Nitrate readings were taken on site using a Satlantic SUNA V2 (Satlantic, 2017). Water levels were also monitored at several wells using barometrically-compensated pressure transducers (Solinst Canada Ltd., 2015). Precipitation levels were monitored using rain gauges and local Environment Canada weather stations (Environment and Climate Change Canada, 2017; Hoskin Scientific, 2017).

All samples were analyzed at the University of Guelph Ridgetown campus for the neonicotinoids acetamiprid, clothianidin, dinotefuran, imidacloprid, thiacloprid, and thiamethoxam. Additionally, samples were analyzed for atrazine, azoxystrobin, cyantraniliprole, mefenoxam, and metolachlor. A field survey was also conducted using crop data for the years 2015 and 2016 (Agriculture and Agri-Food Canada, 2017). This was coupled with a farmer survey that was done in order to estimate the quantity of land-applied neonicotinoids during those years (Appendix D - Farmer Survey Questionnaire).

The field survey and farmer survey revealed that clothianidin and thiamethoxam are the prevalent neonicotinoids used in these research sites. Imidacloprid is also popular throughout the province, but is not widely used on crops in Norfolk or Lanark County. In both of these regions, corn and soybeans are the most popular crops. Corn hybrids typically have either a clothianidin or thiamethoxam seed coating, while soybean varieties are typically planted with a thiamethoxam 
coating. This rate of land applied neonicotinoids is consistent with what was found in groundwater. In total, 228 samples were taken-neonicotinoids were detected above the level of detection and level of quantitation in 17 and 9, respectively, of these samples. However, analysis of triplicate samples taken in the April 2016 found that there is some uncertainty about the samples that are detected between the level of detection and level of quantification. As a result, further analysis and interpretation only occurred on samples with detections of neonicotinoids above the level of quantitation.

A clothianidin peak occurred in August 2016 at three monitoring intervals in Norfolk County, along with one monitoring interval in Lanark County. Clothianidin concentrations at these four intervals ranged from $1.16 \mu \mathrm{g} / \mathrm{L}$ to $2.09 \mu \mathrm{g} / \mathrm{L}$ during that sampling round. Thiamethoxam was found at one monitoring well in Lanark County during the spring freshet of both years $(0.46 \mu \mathrm{g} / \mathrm{L}$ in 2016 and $0.42 \mu \mathrm{g} / \mathrm{L}$ in 2017). Clothianidin was also detected at that well in April 2016 at a concentration of $0.095 \mu \mathrm{g} / \mathrm{L}$. Imidacloprid was found (marginally) above the level of quantification at one monitoring interval in Norfolk County during the July and August sampling rounds at concentrations of $0.07 \mu \mathrm{g} / \mathrm{L}$ and $0.03 \mu \mathrm{g} / \mathrm{L}$, respectively. Overall, clothianidin, imidacloprid, thiamethoxam were detected at frequencies of $2.2 \%, 0.9 \%, 1.3 \%$, respectively.

Neonicotinoid transport was investigated using numerical and analytical models for the monitoring wells LP-MW-02 (in Norfolk County) and TW17 (Lanark County) because they tested positive for clothianidin and thiamethoxam, respectively, at various times throughout the sampling regime. The intention of these modeling exercises was to determine what factors led to the different pattern of neonicotinoid release to these wells. The numerical model Hydrus 1D (Šimůnek et al., 2013) was used to simulate flow and transport through the vadose zone at LP-MW-02, while the analytical Ogata-Banks solution (Ogata and Banks, 1961; Van Genuchten, 1981) was used to simulate transport through the saturated subsurface. At TW17, Hydrus 1D was used to simulate flow through the overburden; the analytical solution for one-dimensional advection with matrix diffusion (Sudicky, 1988; Sudicky and Frind, 1982; Tang et al., 1981) was used to analyze flow through a fracture.

These modelling exercises revealed that the thiamethoxam peak which occurred in Lanark County during the spring freshet was likely influenced by the low permeability overburden near the well. These models found that thiamethoxam is released in a similar manner (albeit more gradually and likely with an earlier peak) than clothianidin under similar environmental conditions. This finding is consistent with the physical properties of these mobile contaminants. The high solubility and low organic carbon-water partitioning coefficient indicate that clothianidin and 
thiamethoxam do not easily sorb to overburden and have a tendency to move with water. These models also revealed that the transport of these two neonicotinoids to groundwater is dominated by processes in the unsaturated zone.

A groundwater monitoring program was conducted between April 2016 and April 2017 in order to investigate the presence and fate of neonicotinoids in groundwater. This research was conducted at two distinct hydrogeological locations: in the sandy, unconfined aquifer of Norfolk County and the fractured bedrock aquifer of Lanark County. Crop data and a farmer survey revealed that the main neonicotinoids used in the two regions were clothianidin and thiamethoxam. Imidacloprid is also used on a smaller scale and was detected twice (in July 2016 and August 2016) at concentrations marginally above the level of quantitation. Clothianidin was found at three wells in Norfolk County and one well in Lanark County during the August 2016 sampling round. All thiamethoxam detections occurred in one well (TW17) during the two spring freshet sampling rounds. This late thiamethoxam peak was attributed to a low permeability overburden which delayed the release of that contaminant to groundwater. Mathematical modelling exercises found that clothianidin and thiamethoxam are likely transported to groundwater as a pulse. This aligns with the field data; however, more frequent sampling rounds should be conducted near neonicotinoid peaks to validate the theory that neonicotinoids move to groundwater in a pulse.

Overall, clothianidin and thiamethoxam were observed at low concentrations in groundwater throughout agriculturally-intensive Norfolk County and the vulnerable groundwater of Lanark County. All groundwater concentrations were at least an order of magnitude lower than what is considered harmful to honeybee, bumblebee, solitary bee, and aquatic invertebrate species. These samples were taken during the time period in which neonicotinoid use was being phased out by the Government of Ontario (Government of Ontario, 2009). The farmer survey revealed that there was only a minor reduction of agricultural neonicotinoid use in 2016; neonicotinoid use will decline dramatically in 2017 and 2018 due to the increasing availability of insecticide alternatives. Maize crops will predominantly use fungicide seed coatings in 2017, while it is expected that many soybean crops will use neonicotinoid seed coatings in 2017 . The fungicide replacement for soybean seed coatings will be in place during the 2018 season in Ontario. The low presence of neonicotinoids in groundwater combined with this ongoing phase-out makes future research into this topic untenable within Ontario. Additionally, the modelling and interpretation portion of this study did not focus on imidacloprid due to the low concentrations found in groundwater. Future studies could build on past research into the presence of imidacloprid in Canadian groundwater resources (Giroux, 2003; Giroux and Sarrasin, 2011); 
however, such research would be contingent on the proposal by the Canadian Pest Management Regulatory Agency to phase-out the use of imidacloprid within three to five years (PMRA, 2016a).

If future studies into the toxicity of neonicotinoids on non-target organisms find that they can be negatively impacted by clothianidin or thiamethoxam at concentrations that have been observed in groundwater, further research should be performed on the probability of contaminated groundwater coming into contact with these organisms.

Overall, the main conclusions from this study about the presence and fate of neonicotinoids in groundwater are as follows:

1. The transport of clothianidin and thiamethoxam are dominated by processes which occur in the vadose zone. When either neonicotinoid reaches groundwater, it can move significant distances within an order of weeks in an unconfined sandy aquifer. They move rapidly (on the order of hours) within a fractured, crystalline bedrock aquifer system.

2. The delayed release of thiamethoxam that occurred at one location in Lanark County was likely due to the relatively low permeability overburden; neonicotinoids can be retained in these types of high risk soils at low concentrations. Mathematical modelling suggests that thiamethoxam can be released from topsoil prior to and in a slightly more gradual manner than clothianidin under similar environmental conditions.

3. Field studies show that neonicotinoids appear to follow an annual cycle with peaks in the late summer into autumn. Mathematical modelling revealed that clothianidin and thiamethoxam appear to occur as a pulse in groundwater. Further field studies should be performed to validate this modelling output. These studies should involve more regular sampling rounds (bi-weekly would likely be sufficient) between late July into early September.

4. Further research into how neonicotinoids move in groundwater within different climatic settings and hydrogeologic settings is recommended. Future studies could also analyze the effects of crop rotations on neonicotinoid movement.

5. Several neonicotinoids are not registered for use in Ontario but are used throughout the United States and many countries in the southern hemisphere. Further research should be conducted to analyze the movement of acetamiprid, dinotefuran, nitenpyram, and thiacloprid to groundwater.

6. While future research into the movement of neonicotinoids to Ontario groundwater is likely untenable due to the ongoing phase-out of these compounds, subsequent studies 
could focus on the presence and fate of any insecticides in groundwater that will be used in lieu of neonicotinoids. 


\subsection{References}

Agriculture and Agri-Food Canada, 2017. AAFC Crop Type Feature Catalog.

Environment and Climate Change Canada, 2017. Historical Data [WWW Document]. URL http://climate.weather.gc.ca/historical_data/search_historic_data_e.html (accessed 6.1.17).

Giroux, I., 2003. Contamination de l'eau souterraine par les pesticides et les nitrates dans les régions en culture de pommes de terre, Campagnes d'Echantillonage.

Giroux, I., Sarrasin, B., 2011. Pesticides et nitrates dans l'eau souterraine près de cultures de pommes de terre - Échantillonnage dans quelques régions du Québec en 2008 et 2009.

Government of Ontario, 2009. Ontario Pesticide Act. Canada.

Hoskin Scientific, 2017. HOBO Rain Gauge Data Logger [WWW Document]. URL https://shoponset.hoskin.ca/products/hobo-rain-gauge-data-logger (accessed 6.29.17).

Ogata, A., Banks, R.B., 1961. A Solution of the Differential Equation of Longitudinal Dispersion in Porous Media, Professional Paper 411-A. Washington, D.C.

PMRA, 2016. Imidacloprid - Proposed Re-Evaluation Decision. Ottawa.

Satlantic, 2017. SUNA [WWW Document]. URL http://satlantic.com/suna Savard, (accessed 6.29.17).

Šimůnek, J., Sejna, M., van Genuchten, M.T., 2013. Code for Simulating the One-Dimensional Movement of Water, Heat, and Multiple Solutes in Variabe Saturated Porous Media.

Solinst Canada Ltd., 2015. Levelogger Series Quick Start Guide. Georgetown, Ontario.

Sudicky, E.A., 1988. CRAFLUSH, Programmer's Guide.

Sudicky, E.A., Frind, E.O., 1982. Contaminant transport in fractured porous media: Analytical solutions for a system of parallel fractures. Water Resour. Res. 18, 1634-1642.

Tang, D.H., Frind, E.O., Sudicky, E.A., 1981. Contaminant transport in fractured porous media: Analytical solution for a single fracture. Water Resour. Res. 17, 555-564.

Van Genuchten, M.T., 1981. Analytical solutions for chemical transport with simultaneous adsorption, zero-order production and first-order decay. J. Hydrol. 49, 213-233. doi:10.1016/0022-1694(81)90214-6 
Appendix A - Well Data 


\begin{tabular}{|c|c|c|c|c|c|c|}
\hline $\begin{array}{l}\text { Long Point } \\
\text { Monitoring Well } \\
\text { ID }\end{array}$ & Latitude & Longitude & $\begin{array}{c}\text { TOC } \\
\text { Elevation } \\
\text { (mASL) }\end{array}$ & $\begin{array}{l}\text { Mid- } \\
\text { Screen } \\
\text { Elevation } \\
\text { (mASL) }\end{array}$ & $\begin{array}{l}\text { Mid- } \\
\text { Screen } \\
\text { Depth } \\
\text { (mBGS) }\end{array}$ & $\begin{array}{c}\text { Screen } \\
\text { Length } \\
\text { (m) }\end{array}$ \\
\hline$L P-M W-01-10$ & 42.8179 & -80.2948 & 218.9 & 212.8 & 5.2 & 3.0 \\
\hline$L P-M W-02-10 S$ & 42.8785 & -80.3040 & 233.0 & 227.6 & 4.6 & 3.1 \\
\hline$L P-M W-02-10 M$ & 42.8785 & -80.3040 & 233.0 & 221.3 & 10.9 & 1.5 \\
\hline$L P-M W-02-10 D$ & 42.8785 & -80.3040 & 233.0 & 212.2 & 19.9 & 1.5 \\
\hline$L P-M W-03-10 S$ & 42.8447 & -80.3347 & 225.4 & 218.3 & 6.1 & 3.0 \\
\hline$L P-M W-03-10 D$ & 42.8447 & -80.3347 & 225.4 & 207.8 & 16.6 & 1.6 \\
\hline LP-MW-04-10 S & 42.8385 & -80.3430 & 224.8 & 219.3 & 4.6 & 3.1 \\
\hline$L P-M W-04-10 M$ & 42.8385 & -80.3430 & 224.8 & 211.5 & 12.4 & 1.5 \\
\hline$L P-M W-04-10 D$ & 42.8385 & -80.3430 & 224.8 & 203.4 & 20.5 & 3.1 \\
\hline$L P-M W-05-10 S$ & 42.8641 & -80.3432 & 226.2 & 222.6 & 2.8 & 3.1 \\
\hline$L P-M W-05-10 D$ & 42.8641 & -80.3431 & 226.1 & 211.9 & 13.4 & 3.0 \\
\hline$L P-M W-06-10 S$ & 42.8738 & -80.3600 & 232.0 & 224.1 & 7.0 & 3.0 \\
\hline LP-MW-06-10 D & 42.8738 & -80.3600 & 232.2 & 219.3 & 11.9 & 1.5 \\
\hline$L P-M W-07-10 \mathrm{~S}$ & 42.8499 & -80.3577 & 229.8 & 221.8 & 7.0 & 3.0 \\
\hline$L P-M W-07-10 D$ & 42.8499 & -80.3577 & 229.8 & 215.4 & 13.1 & 3.0 \\
\hline$L P-M W-08-10 S$ & 42.8358 & -80.3949 & 235.6 & 230.5 & 4.3 & 3.1 \\
\hline$L P-M W-08-10 M$ & 42.8358 & -80.3949 & 235.7 & 214.8 & 20.0 & 1.5 \\
\hline$L P-M W-08-10 D$ & 42.8359 & -80.3949 & 235.7 & 202.7 & 32.0 & 3.0 \\
\hline$L P-M W-09-10 S$ & 42.8308 & -80.3310 & 223.4 & 215.1 & 7.6 & 3.0 \\
\hline LP-MW-09-10 D & 42.8308 & -80.3310 & 223.2 & 198.4 & 24.0 & 3.0 \\
\hline$L P-M W-10-10$ & 42.9077 & -80.3890 & 238.1 & 232.7 & 4.6 & 3.1 \\
\hline$L P-M W-11-10 S$ & 42.8208 & -80.3903 & 237.8 & 230.2 & 6.7 & 3.0 \\
\hline$L P-M W-11-10 D$ & 42.8208 & -80.3903 & 237.8 & 219.3 & 17.6 & 1.5 \\
\hline$L P-M W-12-10$ & 42.9368 & -80.3621 & 240.3 & 233.3 & 6.1 & 3.0 \\
\hline$L P-M W-13-10 S$ & 42.8499 & -80.3866 & 237.0 & 229.9 & 6.1 & 3.0 \\
\hline$L P-M W-13-10 D$ & 42.8499 & -80.3867 & 236.9 & 215.4 & 20.6 & 1.5 \\
\hline$L P-M W-14-10 S$ & 42.8410 & -80.4193 & 239.2 & 233.8 & 4.6 & 3.1 \\
\hline$L P-M W-14-10 M$ & 42.8410 & -80.4193 & 239.2 & 220.1 & 18.5 & 1.5 \\
\hline$L P-M W-14-10 D$ & 42.8410 & -80.4193 & 239.2 & 196.8 & 41.6 & 1.6 \\
\hline$L P-M W-15-10 S$ & 42.8667 & -80.3118 & 223.7 & 218.8 & 4.0 & 3.1 \\
\hline$L P-M W-15-10 M$ & 42.8667 & -80.3118 & 223.7 & 208.6 & 14.2 & 1.5 \\
\hline$L P-M W-15-10 D$ & 42.8667 & -80.3118 & 223.8 & 201.9 & 20.9 & 1.5 \\
\hline
\end{tabular}




\begin{tabular}{|c|c|c|c|c|c|c|}
\hline$L P-M W-16-10 S$ & 42.8134 & -80.4611 & 237.0 & 232.2 & 4.0 & 3.1 \\
\hline$L P-M W-16-10 D$ & 42.8134 & -80.4611 & 237.0 & 203.0 & 33.1 & 1.5 \\
\hline$L P-M W-17-10 S$ & 42.8182 & -80.4305 & 238.4 & 234.2 & 3.4 & 3.1 \\
\hline$L P-M W-17-10 M 1$ & 42.8182 & -80.4305 & 238.3 & 223.1 & 14.5 & 1.5 \\
\hline$L P-M W-17-10 M 2$ & 42.8182 & -80.4305 & 238.3 & 211.0 & 26.7 & 1.5 \\
\hline$L P-M W-17-10 D$ & 42.8182 & -80.4304 & 238.1 & 186.5 & 51.1 & 1.5 \\
\hline$L P-M W-18-10 S$ & 42.8526 & -80.4169 & 239.0 & 233.5 & 4.6 & 3.1 \\
\hline$L P-M W-18-10 M$ & 42.8526 & -80.4169 & 239.0 & 226.6 & 11.5 & 1.5 \\
\hline$L P-M W-18-10 D$ & 42.8526 & -80.4169 & 238.9 & 211.4 & 26.7 & 1.5 \\
\hline$L P-M W-19-10$ & 42.8489 & -80.4457 & 235.5 & 231.2 & 3.7 & 3.1 \\
\hline$L P-M W-20-10 S$ & 42.8621 & -80.6294 & 239.4 & 234.7 & 4.0 & 3.1 \\
\hline$L P-M W-20-10 M$ & 42.8621 & -80.6293 & 239.4 & 224.2 & 14.5 & 1.5 \\
\hline$L P-M W-20-10 D$ & 42.8621 & -80.6294 & 239.4 & 217.5 & 21.1 & 1.5 \\
\hline$L P-M W-21-10 S$ & 42.8216 & -80.5699 & 236.5 & 231.1 & 4.6 & 3.1 \\
\hline$L P-M W-21-10 D$ & 42.8216 & -80.5699 & 236.6 & 220.2 & 15.4 & 1.6 \\
\hline$L P-M W-22-10 S$ & 42.8785 & -80.4113 & 237.6 & 233.3 & 3.7 & 3.1 \\
\hline$L P-M W-22-10 M$ & 42.8785 & -80.4113 & 237.6 & 223.2 & 13.8 & 1.5 \\
\hline$L P-M W-22-10 D$ & 42.8786 & -80.4113 & 237.6 & 187.7 & 49.3 & 1.5 \\
\hline$L P-M W-23-10$ & 42.8980 & -80.8036 & 271.3 & 265.5 & 4.9 & 3.1 \\
\hline$L P-M W-24-10 S$ & 42.8452 & -80.4675 & 235.3 & 230.0 & 4.6 & 3.1 \\
\hline$L P-M W-24-10 M$ & 42.8452 & -80.4675 & 235.2 & 207.9 & 26.7 & 1.5 \\
\hline$L P-M W-24-10 D$ & 42.8452 & -80.4675 & 235.1 & 192.7 & 41.9 & 1.6 \\
\hline$L P-M W-25-10 S$ & 42.8520 & -80.2955 & 229.2 & 225.0 & 3.1 & 3.1 \\
\hline$L P-M W-25-10 M$ & 42.8520 & -80.2955 & 228.5 & 215.1 & 13.0 & 1.5 \\
\hline$L P-M W-25-10 D$ & 42.8520 & -80.2956 & 228.7 & 195.1 & 32.9 & 3.0 \\
\hline$L P-M W-26-10$ & 42.8654 & -80.7026 & 231.2 & 224.9 & 5.2 & 3.0 \\
\hline
\end{tabular}

All wells are $85 \mathrm{~mm}$ in diameter and were drilled using track mounted drill rigs between September of 2010 and January of 2011. All wells are clusters and were completed with grout, holeplugs, and \#2 silica sand to isolate each interval. 


\begin{tabular}{|c|c|c|c|c|c|c|}
\hline $\begin{array}{c}\text { Tay Well } \\
\text { ID }\end{array}$ & Latitude & Longitude & $\begin{array}{c}\text { TOC } \\
\text { Elevation } \\
\text { (mASL) }\end{array}$ & $\begin{array}{c}\text { Mid- } \\
\text { Screen } \\
\text { Elevation } \\
\text { (mASL) }\end{array}$ & $\begin{array}{c}\text { Mid- } \\
\text { Screen } \\
\text { Depth } \\
\text { (mBGS) }\end{array}$ & $\begin{array}{c}\text { Screen } \\
\text { Length } \\
\text { (m) }\end{array}$ \\
\hline TW1S & \multirow{3}{*}{44.8397} & \multirow{3}{*}{-76.3489} & \multirow{3}{*}{158.1} & 154.8 & 3.6 & 6.7 \\
\hline TW1M & & & & 155.7 & 14.3 & 4.9 \\
\hline$T W 1 D$ & & & & 152.3 & 31.4 & 11.6 \\
\hline $\begin{array}{c}\text { TW2 } \\
\text { (open) }\end{array}$ & 44.8394 & -76.3471 & 157.0 & 142.0 & 30.5 & 30 \\
\hline TW3S & \multirow{2}{*}{44.8406} & \multirow{2}{*}{-76.3474} & \multirow{2}{*}{157.0} & 152.0 & 10.1 & 10.1 \\
\hline TW3D & & & & 151.1 & 31.0 & 11.8 \\
\hline TW4S & \multirow{2}{*}{44.8387} & \multirow{2}{*}{-76.3473} & \multirow{2}{*}{155.6} & 152.5 & 6.1 & 6.1 \\
\hline TW4D & & & & 151.4 & 21.6 & 8.4 \\
\hline TW5S & \multirow{3}{*}{44.84} & \multirow{3}{*}{-76.3463} & \multirow{3}{*}{156.5} & 149.6 & 13.1 & 13.7 \\
\hline TW5M & & & & 152.0 & 23.8 & 8.9 \\
\hline TW5D & & & & 147.4 & 56.0 & 18.2 \\
\hline TW6S & \multirow{3}{*}{44.8412} & \multirow{3}{*}{-76.3455} & \multirow{3}{*}{155.4} & 147.0 & 16.0 & 16.8 \\
\hline TW6M & & & & 151.0 & 26.9 & 8.8 \\
\hline TW6D & & & & 150.3 & 49.8 & 10.2 \\
\hline TW7S & \multirow{3}{*}{44.8414} & \multirow{3}{*}{-76.3471} & \multirow{3}{*}{156.5} & 150.1 & 12.2 & 12.8 \\
\hline$T W 7 M$ & & & & 149.8 & 29.9 & 13.4 \\
\hline TW7D & & & & 150.0 & 45.9 & 13 \\
\hline $\begin{array}{c}\text { TW8 } \\
\text { (open) }\end{array}$ & 44.8413 & -76.3471 & 156.2 & 135.7 & 45.7 & 41 \\
\hline TW9S & \multirow{3}{*}{44.8442} & \multirow{3}{*}{-76.3424} & \multirow{3}{*}{152.5} & 149.1 & 6.7 & 6.7 \\
\hline TW9M & & & & 146.6 & 20.8 & 11.8 \\
\hline TW9D & & & & 145.2 & 37.0 & 14.5 \\
\hline TW10S & \multirow{3}{*}{44.8391} & \multirow{3}{*}{-76.351} & \multirow{3}{*}{156.5} & 148.8 & 15.4 & 15.4 \\
\hline TW10M & & & & 150.0 & 33.2 & 12.9 \\
\hline TW10D & & & & 153.6 & 45.3 & 9.1 \\
\hline TW11S & \multirow{3}{*}{44.8418} & \multirow{3}{*}{-76.3596} & \multirow{3}{*}{159.8} & 152.8 & 13.9 & 13.9 \\
\hline TW11M & & & & 154.6 & 28.7 & 10.3 \\
\hline$T W 11 D$ & & & & 157.2 & 36.5 & 5.2 \\
\hline TW12S & \multirow{3}{*}{44.8532} & \multirow{3}{*}{-76.3751} & \multirow{3}{*}{168.0} & 163.1 & 7.4 & 9.9 \\
\hline TW12M & & & & 164.6 & 16.5 & 6.9 \\
\hline TW12D & & & & 162.2 & 32.1 & 11.7 \\
\hline TW13S & 44.8571 & -76.405 & 161.1 & 158.2 & 5.3 & 5.8 \\
\hline
\end{tabular}




\begin{tabular}{|c|c|c|c|c|c|c|}
\hline TW13M & & & & 157.5 & 15.9 & 7.1 \\
\hline$T W 13 D$ & & & & 157.1 & 27.5 & 8 \\
\hline TW15S & \multirow{3}{*}{44.8353} & \multirow{3}{*}{-76.3795} & \multirow{3}{*}{158.1} & 154.2 & 6.0 & 7.8 \\
\hline TW15M & & & & 153.7 & 14.0 & 8.9 \\
\hline$T W 15 D$ & & & & 152.8 & 46.7 & 10.6 \\
\hline TW16S & \multirow{2}{*}{44.86} & \multirow{2}{*}{-76.3483} & \multirow{2}{*}{152.1} & 145.2 & 11.5 & 13.8 \\
\hline$T W 16 D$ & & & & 147.8 & 38.5 & 8.6 \\
\hline $\begin{array}{l}\text { TW17 } \\
\text { (open) }\end{array}$ & 44.8612 & -76.3498 & 152.7 & 140.7 & 25.4 & 24 \\
\hline TW18S & \multirow{2}{*}{44.8533} & \multirow{2}{*}{-76.3274} & \multirow{2}{*}{149.3} & 144.2 & 10.3 & 10.2 \\
\hline TW18D & & & & 141.3 & 28.0 & 15.9 \\
\hline TW19S & \multirow{3}{*}{44.8401} & \multirow{3}{*}{-76.332} & \multirow{3}{*}{148.9} & 142.6 & 10.6 & 12.7 \\
\hline TW19M & & & & -2.9 & 19.2 & 5.8 \\
\hline TW19D & & & & -4.4 & 31.4 & 8.7 \\
\hline $\begin{array}{l}\text { TW20 } \\
\text { (open) }\end{array}$ & 44.8407 & -76.3475 & 156.7 & 149.2 & 15.5 & 15 \\
\hline TW21S & \multirow{3}{*}{44.8616} & \multirow{3}{*}{-76.3146} & \multirow{3}{*}{143.1} & 137.2 & 10.3 & 11.7 \\
\hline TW21M & & & & 139.9 & 19.2 & 6.4 \\
\hline TW21D & & & & 138.3 & 31.2 & 9.5 \\
\hline TW22S & \multirow{3}{*}{44.8563} & \multirow{3}{*}{-76.3126} & \multirow{3}{*}{148.7} & 144.6 & 13.1 & 8.3 \\
\hline TW22M & & & & 146.5 & 18.4 & 4.5 \\
\hline TW22D & & & & 143.0 & 31.0 & 11.5 \\
\hline
\end{tabular}

All well casings are $150 \mathrm{~mm}$ in diameter and were drilled with an air rotary rig between 2004 and 2008. All wells are nested and were completed using $50 \mathrm{~mm}$ PVC pipes with bentonite and \#2 sand to isolate each interval. 
Appendix B - Raw Sampling Data 


\begin{tabular}{|c|c|c|c|c|c|c|c|c|c|c|c|}
\hline \multicolumn{12}{|c|}{ April 2016 Field Data for Norfolk County } \\
\hline Well Label & Date & Time & $\begin{array}{l}\text { Depth to } \\
\text { Water } \\
\text { (m) }\end{array}$ & $\begin{array}{c}\text { Temperature } \\
\left({ }^{\circ} \mathrm{C}\right)\end{array}$ & $\begin{array}{l}\text { Conductivity } \\
\left(\mathrm{mS} / \mathrm{cm}^{2}\right)\end{array}$ & $\begin{array}{c}\mathrm{DO} \\
(\mathrm{mg} / \mathrm{L})\end{array}$ & pH & ORP & $\begin{array}{c}\text { Nitrat } \\
\text { e } \\
(\mathrm{mg} / \\
\mathrm{L})\end{array}$ & $\begin{array}{l}\text { Water } \\
\text { Quality }\end{array}$ & $\begin{array}{l}\text { Water } \\
\text { Quantity }\end{array}$ \\
\hline LP-MW-02-10 M & 07-Apr-16 & 1245 & 9.46 & 10.56 & 0.76 & 7.65 & 7.26 & 12.30 & 6.78 & Dirty & High \\
\hline LP-MW-02-10 D & 07-Apr-16 & 1325 & 9.37 & 9.94 & 0.73 & 7.47 & 7.25 & 31.20 & 6.20 & Clean & High \\
\hline LP-MW-03-10 S & 08-Apr-16 & 1015 & 6.15 & 9.22 & 642.00 & 10.40 & 7.42 & 69.60 & 21.08 & Slightly dirty & Low \\
\hline LP-MW-03-10 D & 08-Apr-16 & 1035 & 6.34 & 10.11 & 0.63 & 9.87 & 7.35 & -110.40 & 0.00 & Clean & High \\
\hline LP-MW-04-10 S & 07-Apr-16 & 1520 & 4.27 & 9.49 & 0.90 & 8.60 & 7.29 & 76.70 & 13.16 & Clean & High \\
\hline LP-MW-04-10 M & 07-Apr-16 & 1535 & 4.33 & 10.38 & 0.64 & 7.63 & 7.26 & 71.10 & 7.88 & Brownish & High \\
\hline LP-MW-04-10 D & 07-Apr-16 & 1550 & 4.36 & 10.10 & 0.63 & 7.34 & 7.32 & -91.40 & 0.00 & Brownish & High \\
\hline LP-MW-05-10 D & 07-Apr-16 & 1805 & 3.21 & 9.23 & 0.35 & 8.97 & 7.37 & -83.30 & 0.00 & Very dirty & High \\
\hline LP-MW-07-10 S & 07-Apr-16 & 1645 & 5.60 & 9.90 & 0.63 & 8.50 & 7.23 & 21.40 & 0.68 & Clean & High \\
\hline LP-MW-07-10 D & 07-Apr-16 & 1720 & 5.62 & 9.61 & 0.57 & 7.95 & 7.22 & -84.40 & 0.71 & Clean & High \\
\hline LP-MW-08-10 M & 08-Apr-16 & 1450 & 3.18 & 9.88 & 0.37 & 7.11 & 7.50 & -80.90 & 5.60 & Dirty & Low-moderate \\
\hline LP-MW-08-10 S & 08-Apr-16 & 1510 & 3.42 & 8.50 & 0.71 & 17.38 & 7.48 & -23.70 & 22.04 & Slightly dirty & Low-moderate \\
\hline LP-MW-10-10 S & 07-Apr-16 & 1025 & 2.20 & 18.19 & 0.69 & 9.03 & 6.88 & -122.70 & 0.00 & Light brown & High \\
\hline LP-MW-11-10 S & 08-Apr-16 & 1120 & 3.49 & 9.02 & 0.43 & 10.90 & 7.33 & 34.50 & 0.00 & Clean & Moderate-high \\
\hline LP-MW-11-10 D & 08-Apr-16 & 1200 & 3.60 & 9.58 & 0.04 & 9.22 & 7.52 & -94.20 & 0.00 & Clean & Moderate-high \\
\hline LP-MW-12-10 S & 07-Apr-16 & 940 & 3.20 & 9.28 & 0.50 & 7.84 & 7.26 & 24.00 & 2.25 & Clean & High \\
\hline LP-MW-14-10 S & 08-Apr-16 & 1605 & 2.63 & 9.44 & 0.29 & 10.31 & 8.04 & -96.70 & 0.09 & Clean & High \\
\hline LP-MW-14-10 M & 08-Apr-16 & 1625 & 2.66 & 9.52 & 1.07 & 10.04 & 7.02 & -97.80 & 0.00 & Greenish & High \\
\hline LP-MW-14-10 D & 08-Apr-16 & 1644 & 3.24 & 9.21 & 0.75 & 10.43 & 7.34 & -57.97 & 0.97 & & \\
\hline LP-MW-17-10 S & 09-Apr-16 & 1315 & 2.69 & 7.68 & 3.08 & 9.36 & 7.04 & 79.20 & $\mathrm{~N} / \mathrm{A}$ & Dirty & Moderate-high \\
\hline LP-MW-17-10 D & 09-Apr-16 & 1225 & 3.42 & 9.18 & 0.25 & 10.34 & 8.13 & 1.40 & 0.06 & Clean & Moderate-high \\
\hline LP-MW-18-10 S & 06-Apr-16 & 1150 & 2.69 & 10.61 & 0.87 & 7.92 & 7.42 & 18.90 & 0.91 & Clean & High \\
\hline LP-MW-18-10 M & $06-A p r-16$ & 1220 & 2.6 & 10.72 & 1.188 & 6.01 & 7.26 & -69.3 & 1.52 & Clean & High \\
\hline
\end{tabular}




\begin{tabular}{|c|c|c|c|c|c|c|c|c|c|c|c|}
\hline LP-MW-19-10 S & $06-A p r-16$ & 1030 & 1.53 & 11.43 & 0.62 & 7.11 & 7.00 & -83.20 & 0.28 & Grey-Green & Low $^{*}$ \\
\hline LP-MW-22-10 S & 07-Apr-16 & 1155 & 1.49 & 9.99 & 1.03 & 7.70 & 6.86 & -63.60 & 0.00 & Dirty gold colour & Low \\
\hline LP-MW-22-10 M & 07-Apr-16 & 1125 & 1.45 & 10.46 & 0.14 & 8.80 & 7.87 & -116.90 & 0.00 & Very dirty & Low \\
\hline
\end{tabular}

\begin{tabular}{|c|c|c|c|c|c|c|c|c|c|c|c|}
\hline \multicolumn{12}{|c|}{ April 2016 Field Data for Lanark County } \\
\hline Well Label & Date & Time & $\begin{array}{l}\text { Depth to } \\
\text { Water } \\
\text { (m) }\end{array}$ & $\begin{array}{c}\text { Temperature } \\
\left({ }^{\circ} \mathrm{C}\right)\end{array}$ & $\begin{array}{c}\text { Conductivity } \\
\left(\mathrm{mS} / \mathrm{cm}^{2}\right)\end{array}$ & $\begin{array}{c}\mathrm{DO} \\
(\mathrm{mg} / \mathrm{L})\end{array}$ & pH & ORP & $\begin{array}{l}\text { Nitrate } \\
(\mathrm{mg} / \mathrm{L})\end{array}$ & $\begin{array}{l}\text { Water } \\
\text { Quality }\end{array}$ & $\begin{array}{c}\text { Water } \\
\text { Quantity }\end{array}$ \\
\hline TW1 S & 19-Apr-16 & 1130 & 2.60 & 6.44 & 0.26 & 10.05 & $\overline{---}$ & $\overline{---}$ & 0.34 & Clean & Low \\
\hline TW1 M & 19-Apr-16 & 1205 & 2.74 & 9.05 & 0.46 & 10.70 & --- & --- & 0.46 & Clean & High \\
\hline TW1 D & 19-Apr-16 & 1240 & 3.67 & 9.51 & 0.52 & 2.57 & --- & --- & 1.22 & Clean & High \\
\hline TW3 S & 20-Apr-16 & 1320 & 2.66 & 9.13 & 0.11 & 6.27 & --- & --- & 0.42 & Clean & High \\
\hline TW4 S & 19-Apr-16 & 1320 & 2.10 & 5.50 & 0.07 & 5.48 & --- & --- & 0.19 & --- & -- \\
\hline TW5 S & 19-Apr-16 & 1410 & 3.82 & 8.63 & 0.37 & 9.99 & --- & --- & 0.51 & Clean & High \\
\hline TW6 S & 19-Apr-16 & 1532 & 3.12 & 9.04 & 0.04 & 8.72 & --- & --- & 0.47 & --- & -- \\
\hline TW7 S & 19-Apr-16 & 915 & 4.35 & 6.07 & 0.46 & 5.35 & --- & --- & 0.11 & Clean & High \\
\hline TW7 D & 19-Apr-16 & 1030 & 4.39 & 8.51 & 0.45 & 7.43 & --- & --- & 0.36 & Clean & High \\
\hline TW8 (open) & 20-Apr-16 & 1205 & 4.38 & 7.70 & 0.41 & 7.39 & --- & --- & 0.11 & Clean & High \\
\hline TW9 S & 18-Apr-16 & 1620 & 1.03 & 6.28 & 0.51 & 1.67 & --- & --- & 0.28 & Clean & High \\
\hline TW11 S & 20-Apr-16 & 1630 & 1.35 & 8.65 & 0.71 & 1.60 & --- & --- & 0.07 & Clean & High \\
\hline TW11 M & 20-Apr-16 & 1705 & 1.34 & 9.41 & 0.69 & 5.00 & --- & --- & 0.03 & Clean & Low \\
\hline TW13 S & 18-Apr-16 & 1825 & 1.28 & 7.44 & 0.38 & 7.40 & --- & --- & 1.20 & Brownish & High \\
\hline TW13 M & 18-Apr-16 & 1845 & 1.25 & 8.64 & 0.34 & 6.11 & --- & --- & 0.38 & Clean & High \\
\hline TW13 D & 18-Apr-16 & 1905 & 1.28 & 8.82 & 0.46 & 3.02 & --- & --- & 0.48 & Clean & High \\
\hline TW16 S & 20-Apr-16 & 955 & 0.71 & 5.79 & 0.59 & 0.48 & --- & --- & 0.00 & Dark, reddish* & High \\
\hline TW16 M & 20-Apr-16 & 1015 & 0.74 & 6.26 & 0.60 & 0.69 & --- & --- & 0.04 & Clean & High \\
\hline TW17 (open) & 20-Apr-16 & 920 & 2.99 & 4.94 & 0.82 & 1.20 & --- & --- & 12.24 & Clean & High \\
\hline TW18 S & 20-Apr-16 & 1730 & 1.18 & 5.95 & 0.46 & 0.53 & --- & --- & 0.00 & --- & -- \\
\hline TW19 S & 18-Apr-16 & 1435 & 1.96 & 6.65 & 0.53 & 0.65 & --- & --- & 0.06 & Clean & High \\
\hline
\end{tabular}




\begin{tabular}{|c|cc|ccccccccc} 
TW19 M & 18-Apr-16 & 1510 & 1.25 & 9.91 & 0.51 & 0.52 & --- & --- & 0.00 & Clean & Moderate-high \\
TW19 D & 18-Apr-16 & 1535 & 1.28 & 9.76 & 0.52 & 0.76 & --- & --- & 0.00 & Clean & High \\
TW20 (open) & $20-$ Apr-16 & 1240 & 2.27 & 7.07 & 0.11 & 5.36 & --- & --- & 0.85 & Clean & High \\
\hline
\end{tabular}

\begin{tabular}{|c|c|c|c|c|c|c|c|c|c|}
\hline \multirow[b]{2}{*}{ Well Label } & \multicolumn{9}{|c|}{ April 2016 Sample Analysis for Norfolk County ( $\mu \mathrm{g} / \mathrm{L})$} \\
\hline & Acetamiprid & Atrazine & Azoxystrobin & Clothianidin & Cyantraniliprole & Dinotefuran & Imidacloprid & Thiacloprid & Thiamethoxam \\
\hline \multirow{3}{*}{ LP-MW-02-10 M } & 0.0000 & 0.0000 & 0.0000 & 0.0000 & 0.0000 & 0.0000 & 0.0028 & 0.0000 & 0.0000 \\
\hline & 0.0000 & 0.0000 & 0.0000 & 0.0000 & 0.0000 & 0.0000 & 0.0000 & 0.0000 & 0.0000 \\
\hline & 0.0000 & 0.0000 & 0.0000 & 0.0000 & 0.0000 & 0.0000 & 0.0000 & 0.0000 & 0.0000 \\
\hline \multirow{3}{*}{ LP-MW-02-10 D } & 0.0000 & 0.0000 & 0.0000 & 0.0000 & 0.0000 & 0.0000 & 0.0212 & 0.0000 & 0.0000 \\
\hline & 0.0000 & 0.0000 & 0.0000 & 0.0223 & 0.0000 & 0.0000 & 0.0020 & 0.0001 & 0.0000 \\
\hline & 0.0000 & 0.0000 & 0.0000 & 0.0000 & 0.0000 & 0.0000 & 0.0000 & 0.0000 & 0.0000 \\
\hline LP-MW-03-10 S & 0.0000 & 0.0000 & 0.0000 & 0.0000 & 0.0000 & 0.0000 & 0.0000 & 0.0000 & 0.0000 \\
\hline \multirow{3}{*}{ LP-MW-03-10 D } & 0.0000 & 0.0000 & 0.0000 & 0.0000 & 0.0000 & 0.0000 & 0.0000 & 0.0000 & 0.0000 \\
\hline & 0.0000 & 0.0000 & 0.0000 & 0.0000 & 0.0000 & 0.0000 & 0.0025 & 0.0000 & 0.0000 \\
\hline & 0.0000 & 0.0000 & 0.0000 & 0.0000 & 0.0000 & 0.0000 & 0.0000 & 0.0000 & 0.0000 \\
\hline \multirow{3}{*}{$\begin{array}{l}\text { LP-MW-04-10 S } \\
\text { (negative) }\end{array}$} & 0.0000 & 0.0000 & 0.0000 & 0.0000 & 0.0000 & 0.0000 & 0.0000 & 0.0000 & 0.0000 \\
\hline & 0.0000 & 0.0000 & 0.0000 & 0.0000 & 0.0000 & 0.0000 & 0.0000 & 0.0000 & 0.0000 \\
\hline & 0.0000 & 0.0000 & 0.0000 & 0.0277 & 0.0000 & 0.0000 & 0.0000 & 0.0000 & 0.0000 \\
\hline LP-MW-04-10 M & 0.0000 & 0.0000 & 0.0000 & 0.0000 & 0.0000 & 0.0000 & 0.0056 & 0.0000 & 0.0000 \\
\hline $\begin{array}{c}\text { LP-MW-04-10 D } \\
\text { (positive) }\end{array}$ & 0.0000 & 0.0000 & 0.0000 & 0.0266 & 0.0000 & 0.0000 & 0.0000 & 0.0000 & 0.0000 \\
\hline \multirow{3}{*}{ LP-MW-05-10 D } & 0.0000 & 0.0000 & 0.0000 & 0.0000 & 0.0000 & 0.0000 & 0.0000 & 0.0000 & 0.0000 \\
\hline & 0.0000 & 0.0000 & 0.0000 & 0.0000 & 0.0000 & 0.0000 & 0.0000 & 0.0000 & 0.0000 \\
\hline & 0.0000 & 0.0000 & 0.0000 & 0.0000 & 0.0000 & 0.0000 & 0.0000 & 0.0000 & 0.0000 \\
\hline \multirow{3}{*}{ LP-MW-07-10 S } & 0.0000 & 0.0024 & 0.0000 & 0.0000 & 0.0000 & 0.0000 & 0.0000 & 0.0000 & 0.0000 \\
\hline & 0.0000 & 0.0038 & 0.0000 & 0.0000 & 0.0000 & 0.0000 & 0.0000 & 0.0000 & 0.0000 \\
\hline & 0.0000 & 0.0085 & 0.0000 & 0.0117 & 0.0000 & 0.0000 & 0.0000 & 0.0000 & 0.0000 \\
\hline LP-MW-07-10 D & 0.0000 & 0.0000 & 0.0000 & 0.0000 & 0.0000 & 0.0000 & 0.0014 & 0.0000 & 0.0000 \\
\hline
\end{tabular}




\begin{tabular}{|c|c|c|c|c|c|c|c|c|c|}
\hline LP-MW-08-10 M & 0.0000 & 0.0000 & 0.0000 & 0.0000 & 0.0000 & 0.0000 & 0.0000 & 0.0000 & 0.0000 \\
\hline \multirow{3}{*}{$\begin{array}{l}\text { LP-MW-08-10 S } \\
\text { (negative) }\end{array}$} & 0.0000 & 0.0000 & 0.0000 & 0.0000 & 0.0000 & 0.0000 & 0.0215 & 0.0000 & 0.0000 \\
\hline & 0.0000 & 0.0099 & 0.0000 & 0.0000 & 0.0000 & 0.0000 & 0.0141 & 0.0000 & 0.0855 \\
\hline & 0.0000 & 0.0000 & 0.0000 & 0.0093 & 0.0000 & 0.0000 & 0.0141 & 0.0000 & 0.0000 \\
\hline \multirow{3}{*}{ LP-MW-10-10 S } & 0.0000 & 0.0000 & 0.0000 & 0.0000 & 0.0000 & 0.0000 & 0.0054 & 0.0000 & 0.0000 \\
\hline & 0.0000 & 0.0000 & 0.0000 & 0.0000 & 0.0000 & 0.0000 & 0.0000 & 0.0000 & 0.0000 \\
\hline & 0.0000 & 0.0000 & 0.0000 & 0.0000 & 0.0000 & 0.0000 & 0.0000 & 0.0000 & 0.0000 \\
\hline \multirow{3}{*}{ LP-MW-11-10 S } & 0.0000 & 0.0000 & 0.0000 & 0.0000 & 0.0000 & 0.0000 & 0.0106 & 0.0000 & 0.0000 \\
\hline & 0.0000 & 0.0000 & 0.0000 & 0.0000 & 0.0000 & 0.0000 & 0.0000 & 0.0000 & 0.0000 \\
\hline & 0.0000 & 0.0000 & 0.0000 & 0.0122 & 0.0000 & 0.0000 & 0.0000 & 0.0000 & 0.0000 \\
\hline LP-MW-11-10 D & 0.0000 & 0.0000 & 0.0000 & 0.0177 & 0.0000 & 0.0000 & 0.0000 & 0.0000 & 0.0000 \\
\hline \multirow{3}{*}{ LP-MW-12-10 S } & 0.0000 & 0.0000 & 0.0000 & 0.0000 & 0.0000 & 0.0000 & 0.0000 & 0.0000 & 0.0000 \\
\hline & 0.0000 & 0.0000 & 0.0000 & 0.0000 & 0.0000 & 0.0000 & 0.0055 & 0.0000 & 0.0000 \\
\hline & 0.0000 & 0.0000 & 0.0000 & 0.0000 & 0.0000 & 0.0000 & 0.0000 & 0.0000 & 0.0000 \\
\hline \multirow{3}{*}{ LP-MW-14-10 S } & 0.0000 & 0.0000 & 0.0000 & 0.0000 & 0.0000 & 0.0000 & 0.0000 & 0.0000 & 0.0000 \\
\hline & 0.0000 & 0.0000 & 0.0000 & 0.0000 & 0.0000 & 0.0000 & 0.0035 & 0.0000 & 0.0000 \\
\hline & 0.0000 & 0.0000 & 0.0000 & 0.0096 & 0.0000 & 0.0000 & 0.0000 & 0.0000 & 0.0000 \\
\hline \multirow{3}{*}{$\begin{array}{l}\text { LP-MW-14-10 M } \\
\text { (negative) }\end{array}$} & 0.0000 & 0.0000 & 0.0000 & 0.0000 & 0.0000 & 0.0000 & 0.0000 & 0.0000 & 0.0000 \\
\hline & 0.0000 & 0.0000 & 0.0057 & 0.0476 & 0.0000 & 0.0000 & 0.0012 & 0.0000 & 0.0000 \\
\hline & 0.0000 & 0.0000 & 0.0000 & 0.0000 & 0.0000 & 0.0000 & 0.0000 & 0.0000 & 0.0000 \\
\hline \multirow{2}{*}{ LP-MW-14-10 D } & 0.0000 & 0.0000 & 0.0000 & 0.0000 & 0.0000 & 0.0000 & 0.0000 & 0.0000 & 0.0000 \\
\hline & 0.0000 & 0.0000 & 0.0000 & 0.0104 & 0.0000 & 0.0000 & 0.0000 & 0.0000 & 0.0000 \\
\hline \multirow{3}{*}{$\begin{array}{l}\text { LP-MW-17-10 S } \\
\text { (negative) }\end{array}$} & 0.0000 & 0.0000 & 0.0000 & 0.0122 & 0.0000 & 0.0000 & 0.0016 & 0.0000 & 0.0160 \\
\hline & 0.0000 & 0.0000 & 0.0000 & 0.0000 & 0.0000 & 0.0000 & 0.0000 & 0.0000 & 0.0000 \\
\hline & 0.0000 & 0.0000 & 0.0000 & 0.0000 & 0.0000 & 0.0000 & 0.0000 & 0.0000 & 0.0000 \\
\hline \multirow{3}{*}{ LP-MW-17-10 D } & 0.0000 & 0.0000 & 0.0000 & 0.0000 & 0.0000 & 0.0000 & 0.0000 & 0.0000 & 0.0000 \\
\hline & 0.0000 & 0.0000 & 0.0000 & 0.0000 & 0.0000 & 0.0000 & 0.0030 & 0.0000 & 0.0000 \\
\hline & 0.0000 & 0.0000 & 0.0000 & 0.0000 & 0.0000 & 0.0000 & 0.0000 & 0.0000 & 0.0000 \\
\hline LP-MW-18-10 S & 0.0000 & 0.0000 & 0.0000 & 0.0000 & 0.0000 & 0.0000 & 0.0000 & 0.0000 & 0.0000 \\
\hline LP-MW-18-10 M & 0.0000 & 0.0000 & 0.0000 & 0.0000 & 0.0000 & 0.0000 & 0.0000 & 0.0000 & 0.0000 \\
\hline
\end{tabular}




\begin{tabular}{|c|c|c|c|c|c|c|c|c|c|}
\hline & 0.0000 & 0.0000 & 0.0000 & 0.0000 & 0.0000 & 0.0000 & 0.0000 & 0.0000 & 0.0097 \\
\hline & 0.0000 & 0.0000 & 0.0000 & 0.0217 & 0.0000 & 0.0000 & 0.0041 & 0.0000 & 0.0000 \\
\hline \multirow{3}{*}{$\begin{array}{l}\text { LP-MW-19-10 S } \\
\text { (negative) }\end{array}$} & 0.0000 & 0.0000 & 0.0000 & 0.0710 & 0.0000 & 0.0000 & 0.0000 & 0.0000 & 0.0000 \\
\hline & 0.0000 & 0.0000 & 0.0000 & 0.0000 & 0.0000 & 0.0000 & 0.0081 & 0.0000 & 0.0000 \\
\hline & 0.0000 & 0.0000 & 0.0000 & 0.0000 & 0.0000 & 0.0000 & 0.0040 & 0.0000 & 0.0000 \\
\hline \multirow{3}{*}{ LP-MW-22-10 S } & 0.0000 & 0.0000 & 0.0000 & 0.0000 & 0.0000 & 0.0000 & 0.0045 & 0.0000 & 0.0000 \\
\hline & 0.0000 & 0.0000 & 0.0000 & 0.0000 & 0.0000 & 0.0000 & 0.0000 & 0.0000 & 0.0000 \\
\hline & 0.0000 & 0.0000 & 0.0000 & 0.0000 & 0.0000 & 0.0000 & 0.0036 & 0.0000 & 0.0000 \\
\hline \multirow{3}{*}{ LP-MW-22-10 M } & 0.0000 & 0.0000 & 0.0000 & 0.0000 & 0.0000 & 0.0000 & 0.0036 & 0.0000 & 0.0000 \\
\hline & 0.0000 & 0.0000 & 0.0000 & 0.0000 & 0.0000 & 0.0000 & 0.0000 & 0.0000 & 0.0000 \\
\hline & 0.0000 & 0.0000 & 0.0000 & 0.0000 & 0.0000 & 0.0000 & 0.0090 & 0.0000 & 0.0000 \\
\hline Equipment Blank & 0.0000 & 0.0000 & 0.0000 & 0.0000 & 0.0000 & 0.0000 & 0.0036 & 0.0000 & 0.0000 \\
\hline Blank & 0.0000 & 0.0000 & 0.0000 & 0.0000 & 0.0000 & 0.0000 & 0.0000 & 0.0000 & 0.0000 \\
\hline $\operatorname{LOD}(\mu \mathrm{g} / \mathrm{L})$ & 0.0138 & 0.0096 & 0.0022 & 0.0223 & 0.0037 & 0.0120 & 0.0268 & 0.0038 & 0.0127 \\
\hline $\mathrm{LOQ}(\mu \mathrm{g} / \mathrm{L})$ & 0.0461 & 0.0319 & 0.0074 & 0.0744 & 0.0124 & 0.0399 & 0.0892 & 0.0127 & 0.0422 \\
\hline
\end{tabular}

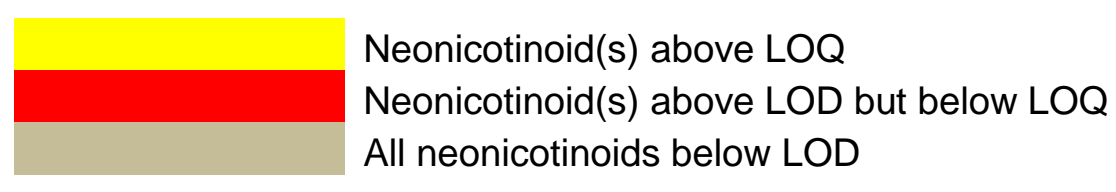

\begin{tabular}{|c|c|c|c|c|c|c|c|c|c|}
\hline \multicolumn{10}{|c|}{ April 2016 Sample Analysis for Lanark County ( $\mu g / L)$} \\
\hline Well Label & Acetamiprid & Atrazine & Azoxystrobin & Clothianidin & Cyantraniliprole & Dinotefuran & Imidacloprid & Thiacloprid & Thiamethoxam \\
\hline \multirow{3}{*}{ TW1 S } & 0.0000 & 0.0126 & 0.0000 & 0.0000 & 0.0000 & 0.0000 & 0.0000 & 0.0000 & 0.0000 \\
\hline & 0.0000 & 0.0033 & 0.0000 & 0.0000 & 0.0000 & 0.0000 & 0.0028 & 0.0000 & 0.0000 \\
\hline & 0.0000 & 0.0069 & 0.0000 & 0.0000 & 0.0000 & 0.0000 & 0.0000 & 0.0000 & 0.0000 \\
\hline \multirow{2}{*}{$\begin{array}{c}\text { TW1 M } \\
\text { (average below } \\
\text { LOQ) }\end{array}$} & 0.0000 & 0.0564 & 0.0000 & 0.0000 & 0.0000 & 0.0000 & 0.0000 & 0.0000 & 0.0000 \\
\hline & 0.0000 & 0.0548 & 0.0000 & 0.1199 & 0.0000 & 0.0000 & 0.0000 & 0.0000 & 0.0092 \\
\hline \multirow{2}{*}{ TW1 D } & 0.0000 & 0.0846 & 0.0000 & 0.0000 & 0.0000 & 0.0000 & 0.0000 & 0.0000 & 0.0000 \\
\hline & 0.0000 & 0.0865 & 0.0000 & 0.0000 & 0.0000 & 0.0000 & 0.0000 & 0.0000 & 0.0000 \\
\hline
\end{tabular}




\begin{tabular}{|c|c|c|c|c|c|c|c|c|c|}
\hline & 0.0000 & 0.0666 & 0.0000 & 0.0000 & 0.0000 & 0.0000 & 0.0000 & 0.0000 & 0.0000 \\
\hline \multirow{3}{*}{$\begin{array}{c}\text { TW3 S } \\
\text { (negative) }\end{array}$} & 0.0000 & 0.0000 & 0.0000 & 0.0000 & 0.0000 & 0.0000 & 0.0023 & 0.0000 & 0.0000 \\
\hline & 0.0000 & 0.0000 & 0.0000 & 0.0000 & 0.0000 & 0.0000 & 0.0014 & 0.0000 & 0.0000 \\
\hline & 0.0000 & 0.0000 & 0.0000 & 0.0276 & 0.0000 & 0.0000 & 0.0022 & 0.0000 & 0.0000 \\
\hline \multirow{3}{*}{$\begin{array}{c}\text { TW4 S } \\
\text { (negative) }\end{array}$} & 0.0000 & 0.0000 & 0.0000 & 0.0000 & 0.0000 & 0.0000 & 0.0000 & 0.0000 & 0.0000 \\
\hline & 0.0000 & 0.0000 & 0.0000 & 0.0000 & 0.0000 & 0.0000 & 0.0033 & 0.0000 & 0.0000 \\
\hline & 0.0000 & 0.0000 & 0.0000 & 0.0238 & 0.0000 & 0.0000 & 0.0042 & 0.0000 & 0.0000 \\
\hline \multirow{2}{*}{ TW5 S } & 0.0000 & 0.0000 & 0.0000 & 0.0000 & 0.0000 & 0.0000 & 0.0013 & 0.0000 & 0.0000 \\
\hline & 0.0000 & 0.0028 & 0.0000 & 0.0000 & 0.0000 & 0.0000 & 0.0032 & 0.0000 & 0.0000 \\
\hline TW6 S & 0.0000 & 0.0035 & 0.0000 & 0.0000 & 0.0000 & 0.0000 & 0.0000 & 0.0000 & 0.0000 \\
\hline TW7 S & 0.0000 & 0.0000 & 0.0000 & 0.0000 & 0.0000 & 0.0000 & 0.0023 & 0.0000 & 0.0000 \\
\hline \multirow{3}{*}{ TW7 D } & 0.0000 & 0.0087 & 0.0000 & 0.0000 & 0.0000 & 0.0000 & 0.0000 & 0.0000 & 0.0000 \\
\hline & 0.0000 & 0.0000 & 0.0000 & 0.0000 & 0.0000 & 0.0000 & 0.0000 & 0.0000 & 0.0000 \\
\hline & 0.0000 & 0.0053 & 0.0000 & 0.0000 & 0.0000 & 0.0000 & 0.0000 & 0.0000 & 0.0000 \\
\hline \multirow{3}{*}{ TW8 (open) } & 0.0000 & 0.0000 & 0.0000 & 0.0000 & 0.0000 & 0.0000 & 0.0000 & 0.0000 & 0.0000 \\
\hline & 0.0000 & 0.0043 & 0.0000 & 0.0000 & 0.0000 & 0.0000 & 0.0000 & 0.0000 & 0.0000 \\
\hline & 0.0000 & 0.0051 & 0.0000 & 0.0000 & 0.0000 & 0.0000 & 0.0000 & 0.0000 & 0.0000 \\
\hline \multirow{3}{*}{ TW9 S } & 0.0000 & 0.0052 & 0.0000 & 0.0000 & 0.0000 & 0.0000 & 0.0000 & 0.0000 & 0.0000 \\
\hline & 0.0000 & 0.0074 & 0.0000 & 0.0058 & 0.0000 & 0.0000 & 0.0023 & 0.0000 & 0.0000 \\
\hline & 0.0000 & 0.0075 & 0.0000 & 0.0000 & 0.0000 & 0.0000 & 0.0000 & 0.0000 & 0.0000 \\
\hline \multirow{3}{*}{ TW11 S } & 0.0000 & 0.0000 & 0.0000 & 0.0000 & 0.0000 & 0.0000 & 0.0000 & 0.0000 & 0.0000 \\
\hline & 0.0000 & 0.0000 & 0.0000 & 0.0000 & 0.0000 & 0.0000 & 0.0000 & 0.0000 & 0.0000 \\
\hline & 0.0000 & 0.0000 & 0.0000 & 0.0000 & 0.0000 & 0.0000 & 0.0023 & 0.0000 & 0.0000 \\
\hline \multirow{3}{*}{$\begin{array}{l}\text { TW11 M } \\
\text { (negative) }\end{array}$} & 0.0000 & 0.0000 & 0.0000 & 0.0226 & 0.0000 & 0.0000 & 0.0000 & 0.0000 & 0.0000 \\
\hline & 0.0000 & 0.0000 & 0.0000 & 0.0000 & 0.0000 & 0.0000 & 0.0000 & 0.0000 & 0.0000 \\
\hline & 0.0000 & 0.0000 & 0.0000 & 0.0000 & 0.0000 & 0.0000 & 0.0000 & 0.0000 & 0.0000 \\
\hline \multirow{3}{*}{ TW13 S } & 0.0000 & 0.0000 & 0.0000 & 0.0000 & 0.0000 & 0.0000 & 0.0000 & 0.0000 & 0.0000 \\
\hline & 0.0000 & 0.0000 & 0.0000 & 0.0000 & 0.0000 & 0.0000 & 0.0000 & 0.0000 & 0.0000 \\
\hline & 0.0000 & 0.0000 & 0.0000 & 0.0000 & 0.0000 & 0.0000 & 0.0000 & 0.0000 & 0.0000 \\
\hline TW13 M & 0.0000 & 0.0000 & 0.0000 & 0.0000 & 0.0000 & 0.0000 & 0.0000 & 0.0000 & 0.0000 \\
\hline
\end{tabular}




\begin{tabular}{|c|c|c|c|c|c|c|c|c|c|}
\hline & 0.0000 & 0.0000 & 0.0000 & 0.0000 & 0.0000 & 0.0000 & 0.0000 & 0.0000 & 0.0000 \\
\hline & 0.0000 & 0.0000 & 0.0000 & 0.0000 & 0.0000 & 0.0000 & 0.0000 & 0.0000 & 0.0000 \\
\hline \multirow{3}{*}{ TW13 D } & 0.0000 & 0.0000 & 0.0000 & 0.0000 & 0.0000 & 0.0000 & 0.0000 & 0.0000 & 0.0000 \\
\hline & 0.0000 & 0.0000 & 0.0000 & 0.0000 & 0.0000 & 0.0000 & 0.0000 & 0.0000 & 0.0000 \\
\hline & 0.0000 & 0.0000 & 0.0000 & 0.0000 & 0.0000 & 0.0000 & 0.0000 & 0.0000 & 0.0000 \\
\hline \multirow{3}{*}{ TW16 S } & 0.0000 & 0.0000 & 0.0000 & 0.0000 & 0.0000 & 0.0000 & 0.0000 & 0.0000 & 0.0000 \\
\hline & 0.0000 & 0.0000 & 0.0000 & 0.0000 & 0.0000 & 0.0000 & 0.0000 & 0.0000 & 0.0000 \\
\hline & 0.0000 & 0.0000 & 0.0000 & 0.0000 & 0.0000 & 0.0000 & 0.0000 & 0.0000 & 0.0000 \\
\hline \multirow{3}{*}{ TW16 M } & 0.0000 & 0.0000 & 0.0000 & 0.0000 & 0.0000 & 0.0000 & 0.0033 & 0.0000 & 0.0000 \\
\hline & 0.0000 & 0.0000 & 0.0000 & 0.0096 & 0.0000 & 0.0000 & 0.0000 & 0.0000 & 0.0000 \\
\hline & 0.0000 & 0.0000 & 0.0000 & 0.0000 & 0.0000 & 0.0000 & 0.0000 & 0.0000 & 0.0000 \\
\hline \multirow{3}{*}{ TW17 (open) } & 0.0000 & 0.2168 & 0.0000 & 0.0956 & 0.0000 & 0.0000 & 0.0130 & 0.0000 & 0.4349 \\
\hline & 0.0000 & 0.2159 & 0.0000 & 0.0835 & 0.0000 & 0.0000 & 0.0050 & 0.0000 & 0.4995 \\
\hline & 0.0000 & 0.2006 & 0.0000 & 0.1047 & 0.0000 & 0.0000 & 0.0106 & 0.0000 & 0.4373 \\
\hline \multirow{3}{*}{ TW18 S } & 0.0000 & 0.0045 & 0.0000 & 0.0000 & 0.0000 & 0.0000 & 0.0000 & 0.0000 & 0.0000 \\
\hline & 0.0000 & 0.0087 & 0.0000 & 0.0000 & 0.0000 & 0.0000 & 0.0000 & 0.0000 & 0.0000 \\
\hline & 0.0000 & 0.0089 & 0.0000 & 0.0000 & 0.0000 & 0.0000 & 0.0000 & 0.0000 & 0.0000 \\
\hline \multirow{3}{*}{ TW19 S } & 0.0000 & 0.0000 & 0.0000 & 0.0000 & 0.0000 & 0.0000 & 0.0000 & 0.0000 & 0.0000 \\
\hline & 0.0000 & 0.0000 & 0.0000 & 0.0000 & 0.0000 & 0.0000 & 0.0000 & 0.0000 & 0.0000 \\
\hline & 0.0000 & 0.0000 & 0.0000 & 0.0000 & 0.0000 & 0.0000 & 0.0000 & 0.0000 & 0.0000 \\
\hline \multirow{3}{*}{ TW19 M } & 0.0000 & 0.0000 & 0.0000 & 0.0000 & 0.0000 & 0.0000 & 0.0059 & 0.0000 & 0.0000 \\
\hline & 0.0000 & 0.0000 & 0.0000 & 0.0143 & 0.0000 & 0.0000 & 0.0166 & 0.0000 & 0.0018 \\
\hline & 0.0000 & 0.0013 & 0.0000 & 0.0000 & 0.0000 & 0.0000 & 0.0056 & 0.0000 & 0.0000 \\
\hline \multirow{3}{*}{ TW19 D } & 0.0000 & 0.0000 & 0.0000 & 0.0000 & 0.0000 & 0.0000 & 0.0025 & 0.0000 & 0.0000 \\
\hline & 0.0000 & 0.0000 & 0.0000 & 0.0000 & 0.0000 & 0.0000 & 0.0012 & 0.0000 & 0.0000 \\
\hline & 0.0000 & 0.0018 & 0.0000 & 0.0000 & 0.0000 & 0.0000 & 0.0000 & 0.0000 & 0.0000 \\
\hline \multirow{3}{*}{ TW20 (open) } & 0.0000 & 0.0000 & 0.0000 & 0.0000 & 0.0000 & 0.0000 & 0.0000 & 0.0000 & 0.0000 \\
\hline & 0.0000 & 0.0000 & 0.0000 & 0.0000 & 0.0000 & 0.0000 & 0.0011 & 0.0000 & 0.0000 \\
\hline & 0.0000 & 0.0000 & 0.0000 & 0.0000 & 0.0000 & 0.0000 & 0.0000 & 0.0000 & 0.0000 \\
\hline LOD ( $\mu \mathrm{g} / \mathrm{L})$ & 0.0138 & 0.0096 & 0.0022 & 0.0223 & 0.0037 & 0.0120 & 0.0268 & 0.0038 & 0.0127 \\
\hline
\end{tabular}


Neonicotinoid(s) above LOQ

Neonicotinoid(s) above LOD but below LOQ

All neonicotinoids below LOD 


\begin{tabular}{|c|c|c|c|c|c|c|c|c|c|c|c|}
\hline \multicolumn{12}{|c|}{ July 2016 Field Data for Norfolk County } \\
\hline Well Label & Date & Time & $\begin{array}{l}\text { Depth to } \\
\text { Water } \\
\text { (m) }\end{array}$ & $\begin{array}{c}\text { Temperature } \\
\left({ }^{\circ} \mathrm{C}\right)\end{array}$ & $\begin{array}{c}\text { Conductivity } \\
\left(\mathrm{mS} / \mathrm{cm}^{2}\right)\end{array}$ & $\begin{array}{c}\mathrm{DO} \\
(\mathrm{mg} / \mathrm{L})\end{array}$ & $\mathbf{p H}$ & ORP & $\begin{array}{l}\text { Nitrate } \\
\text { (mg/L) }\end{array}$ & $\begin{array}{l}\text { Water } \\
\text { Quality }\end{array}$ & $\begin{array}{c}\text { Water } \\
\text { Quantity }\end{array}$ \\
\hline LP-MW-02-10 M & $04 / 07 / 2016$ & 1896 & 9.84 & 11.92 & 0.711 & 8.41 & 6.71 & 76 & 6.8 & Clear & High Flow \\
\hline LP-MW-02-10 D & 04/07/2016 & 1829 & 9.74 & 11.55 & 0.697 & 8.19 & 7.05 & 72.90 & 10.49 & Clear & High Flow \\
\hline LP-MW-03-10 S & 04/07/2016 & 2012 & 6.13 & 11.87 & 0.633 & 14.97 & 6.65 & 58.80 & 34.09 & Brown \& sandy & High Flow \\
\hline LP-MW-03-10 D & 04/07/2016 & 2037 & 6.33 & 11.39 & 0.563 & 3.86 & 7.04 & -123.60 & 0.00 & $\begin{array}{l}\text { Yellow-brown. } \\
\text { Sand present }\end{array}$ & High Flow \\
\hline LP-MW-04-10 S & 02/07/2016 & 1419 & 4.39 & 12.40 & 0.961 & 11.20 & 6.85 & 41.80 & 12.96 & Clear & High Flow \\
\hline LP-MW-04-10 M & 02/07/2016 & 1509 & 4.45 & 12.74 & 0.613 & 10.15 & 6.62 & 75.80 & 8.36 & Clear & High Flow \\
\hline LP-MW-04-10 D & 04/07/2016 & 2111 & 4.50 & 10.83 & 0.560 & 3.60 & 6.98 & -121.50 & 0.40 & Clear & High flow \\
\hline LP-MW-05-10 D & 04/07/2016 & 1926 & 3.75 & 11.00 & 0.407 & 4.16 & 6.85 & -126.70 & 0.10 & Brownish & High Flow \\
\hline LP-MW-07-10 S & $02 / 07 / 2016$ & 1301 & 5.76 & 11.90 & 0.586 & 10.30 & 6.46 & 67.10 & 5.24 & Clear & High Flow \\
\hline LP-MW-07-10 D & 02/07/2016 & 1341 & 5.80 & 12.12 & 0.548 & 4.16 & 7.03 & 100.20 & 0.00 & Clear & High Flow \\
\hline LP-MW-08-10 D & $10 / 07 / 2016$ & --- & 4.09 & --- & --- & --- & --- & --- & --- & --- & -- \\
\hline LP-MW-08-10 M & $10 / 07 / 2016$ & --- & 4.00 & --- & --- & --- & --- & --- & --- & --- & --- \\
\hline LP-MW-08-10 S & $10 / 07 / 2016$ & 1402 & 3.39 & 75.16 & 1.865 & 11.16 & 10.98 & 58.90 & 20.52 & Clear & Low Flow \\
\hline LP-MW-10-10 S & 01/07/2016 & 1401 & 2.67 & 10.32 & 0.685 & 3.98 & 6.64 & -158.90 & 0.06 & Clear & High Flow \\
\hline LP-MW-11-10 S & $10 / 07 / 2016$ & 1543 & 4.52 & 9.70 & 0.434 & 15.61 & 11.77 & 54.60 & 0.11 & Clear & Moderate \\
\hline LP-MW-11-10 D & $06 / 07 / 2016$ & 1523 & 4.66 & 11.77 & 0.369 & 3.45 & 11.8 & -109.90 & 0.32 & Cloudy & $\begin{array}{l}\text { Low- } \\
\text { moderate }\end{array}$ \\
\hline LP-MW-12-10 S & 01/07/2016 & 1303 & 3.62 & 10.59 & 0.476 & 5.85 & 6.65 & -24.50 & 2.71 & Clear & High Flow \\
\hline LP-MW-14-10 S & $01 / 07 / 2016$ & 1905 & 3.27 & 10.80 & 0.576 & 6.13 & 6.9 & -30.40 & 1.69 & Cloudy & High Flow \\
\hline LP-MW-14-10 M & $01 / 07 / 2016$ & 1844 & 3.30 & 11.46 & 1.049 & 3.58 & 6.8 & -108.70 & 0.00 & Clear & High Flow \\
\hline LP-MW-14-10 D & $01 / 07 / 2016$ & 1821 & 4.01 & 11.68 & 0.280 & 3.73 & 6.72 & -132.70 & 0.00 & Clear & High Flow \\
\hline LP-MW-17-10 S & $04 / 07 / 2016$ & 1144 & 3.68 & 12.41 & 2.693 & 13.50 & 6.23 & 107.50 & 7.06 & $\begin{array}{l}\text { Brownish } \\
\text { before purge }\end{array}$ & High Flow \\
\hline LP-MW-17-10 M14 & 04/07/2016 & --- & 3.62 & --- & --- & --- & --- & --- & --- & --- & --- \\
\hline
\end{tabular}




\begin{tabular}{|c|c|c|c|c|c|c|c|c|c|c|c|}
\hline LP-MW-17-10 M26 & 04/07/2016 & --- & 4.10 & --- & --- & --- & --- & --- & --- & --- & --- \\
\hline LP-MW-17-10 D & 10/07/2016 & 1628 & 3.83 & 14.81 & 0.233 & 2.80 & 10.98 & 16.30 & 0.21 & Clear & Low flow \\
\hline LP-MW-18-10 S & 01/07/2016 & 1647 & 3.44 & 11.81 & 0.602 & 14.16 & 7.45 & 74.00 & 1.97 & Cloudy & High Flow \\
\hline LP-MW-18-10 M & 01/07/2016 & 1717 & 3.34 & 12.01 & 1.131 & 3.71 & 6.93 & -18.90 & 1.45 & Clear & High Flow \\
\hline LP-MW-19-10 S & $01 / 07 / 2016$ & 1950 & 2.07 & 10.28 & 0.591 & 4.28 & 7.03 & -98.80 & 0.06 & Greenish & High Flow \\
\hline LP-MW-22-10 S & 01/07/2016 & 1549 & 2.44 & 11.71 & 1.088 & 3.60 & 6.84 & -85.80 & 0.09 & Clear & High Flow \\
\hline LP-MW-22-10 M & $01 / 07 / 2016$ & 1524 & 2.29 & 18.62 & 0.003 & 11.56 & 6.29 & -28.00 & --- & Cloudy & High Flow \\
\hline
\end{tabular}

\begin{tabular}{|c|c|c|c|c|c|c|c|c|c|c|c|}
\hline \multicolumn{12}{|c|}{ July 2016 Field Data for Lanark County } \\
\hline Well Label & Date & Time & $\begin{array}{l}\text { Depth to } \\
\text { Water (m) }\end{array}$ & $\begin{array}{c}\text { Temperature } \\
\left({ }^{\circ} \mathrm{C}\right)\end{array}$ & $\begin{array}{l}\text { Conductivity } \\
\left(\mathrm{mS} / \mathrm{cm}^{2}\right)\end{array}$ & $\begin{array}{c}\mathrm{DO} \\
(\mathrm{mg} / \mathrm{L})\end{array}$ & pH & ORP & $\begin{array}{l}\text { Nitrate } \\
\text { (mg/L) }\end{array}$ & $\begin{array}{l}\text { Water } \\
\text { Quality }\end{array}$ & $\begin{array}{c}\text { Water } \\
\text { Quantity }\end{array}$ \\
\hline TW1 S & $06 / 07 / 2016$ & & Dry & --- & --- & --- & --- & --- & --- & --- & --- \\
\hline TW1 M & 06/07/2016 & 1229 & 5.01 & 11.23 & 0.512 & 12.18 & 6.83 & 48.50 & 1.18 & Clear & High Flow \\
\hline TW1 D & 06/07/2016 & 1251 & 2.35 & 11.52 & 0.545 & 5.89 & 6.86 & 25.60 & 1.36 & Clear & Moderate-high flow \\
\hline TW3 S & 08/07/2016 & 1018 & 5.79 & 12.31 & 0.303 & 10.05 & 11.6 & -48.00 & 0.23 & Black particulate present & Low Flow \\
\hline TW3D & 08/07/2016 & --- & 5.64 & --- & --- & --- & --- & --- & --- & Black particulate present & --- \\
\hline TW4 S & 07/07/2016 & --- & 3.13 & --- & --- & --- & --- & --- & --- & --- & --- \\
\hline TW4D & $07 / 07 / 2016$ & 1205 & 2.85 & 10.59 & 0.528 & 12.25 & 6.06 & 78.70 & -- & $\begin{array}{l}\text { Yellow-brown. Sand } \\
\text { present }\end{array}$ & $\begin{array}{l}\text { Low flow (bailer } \\
\text { was used) }\end{array}$ \\
\hline--- & 07/07/2016 & 1151 & --- & 26.49 & 0.149 & 11.17 & 6.42 & 65.5 & --- & Clear & --- \\
\hline TW5 S & 07/07/2016 & 1007 & 4.83 & 10.10 & 0.411 & 12.41 & 6.81 & 87.6 & 1.02 & Clear & High Flow \\
\hline TW6 S & 07/07/2016 & 939 & 4.46 & 9.55 & 0.387 & 14.40 & 6.74 & 107 & 0.55 & Clear & High Flow \\
\hline TW7 S & 06/07/2016 & 1114 & 5.88 & 11.46 & 0.488 & 4.27 & 5.66 & 22.4 & 0.12 & Clear & High Flow \\
\hline TW7M & 06/07/2016 & 1146 & 5.87 & 11.26 & 0.519 & 5.07 & 5.8 & 8 & 0.08 & Clear & Moderate-high flow \\
\hline TW7 D & 06/07/2016 & 1133 & 5.77 & 10.44 & 0.527 & 8.76 & 5.8 & 45.7 & 0.68 & Clear & Moderate-high flow \\
\hline TW8 (open) & 06/07/2016 & 1546 & 5.62 & 10.46 & 0.448 & 8.17 & 7.25 & -2.1 & 0.18 & Clear & Low Flow \\
\hline TW9 S & 06/07/2016 & 1031 & 1.90 & 10.78 & 0.586 & 3.85 & 5.84 & -79.9 & 0.06 & Clear & High Flow \\
\hline TW11 S & 08/07/2016 & --- & 2.73 & --- & --- & --- & --- & --- & --- & --- & --- \\
\hline TW11 M & | 08/07/2016 & 1447 & 2.77 & 17.78 & 0.774 & 2.84 & 7.16 & -43 & 0.17 & Clear & Very low flow \\
\hline
\end{tabular}




\begin{tabular}{|c|c|c|c|c|c|c|c|c|c|c|c|}
\hline TW11D & 08/07/2016 & 1334 & 2.78 & 18.35 & 0.762 & 2.34 & 7.12 & -53.7 & 0.09 & Clear & Very low flow \\
\hline TW13 S & 08/07/2016 & 1539 & 2.49 & 14.05 & 0.340 & 6.07 & 10.8 & -33 & 0.24 & Iron present & Low-moderate \\
\hline TW13 M & 08/07/2016 & 1612 & 2.49 & 11.29 & 0.319 & 8.35 & 11.1 & $38 . .6$ & 0.25 & Clear & Low-moderate \\
\hline TW13 D & 08/07/2016 & 1641 & 2.48 & 9.66 & 0.305 & 9.66 & 11.9 & 43.4 & 0.28 & Clear & Low-moderate \\
\hline TW16 S & 07/07/2016 & 1497 & 1.55 & 10.06 & 0.819 & 4.06 & 6.56 & -113.3 & 0.16 & Cloudy & High Flow \\
\hline TW16 M & 07/07/2016 & 1530 & 1.53 & 9.35 & 0.827 & 4.10 & 6.58 & 65.3 & 0.1 & Clear & High Flow \\
\hline TW17 (open) & 07/07/2016 & 1402 & 2.95 & 10.27 & 0.687 & 4.76 & 6.96 & 32.3 & 7.94 & Clear & High Flow \\
\hline TW18 S & 07/07/2016 & 1610 & 2.73 & 10.37 & 0.537 & 5.24 & 6.67 & -44.2 & 0.05 & Clear & High Flow \\
\hline TW19 S & 06/07/2016 & 924 & 2.82 & 12.64 & 0.606 & 4.00 & 5.21 & -17.9 & 0.14 & Clear & High Flow \\
\hline TW19 M & 06/07/2016 & --- & --- & --- & --- & --- & --- & --- & --- & --- & --- \\
\hline TW19 D & 06/07/2016 & 947 & 2.31 & 9.75 & 0.548 & 3.77 & 6.76 & -74.2 & 0.08 & Clear & High Flow \\
\hline TW20 (open) & 06/07/2016 & 1500 & 5.49 & 20.89 & 0.178 & 2.20 & 5.75 & 61 & 0.56 & Light brown / gold & Very low flow \\
\hline
\end{tabular}

\begin{tabular}{|c|c|c|c|c|c|c|c|c|c|c|c|}
\hline \multicolumn{12}{|c|}{ July 2016 Sample Analysis for Norfolk and Lanark County ( $\mu \mathrm{g} / \mathrm{L})$} \\
\hline Well Label & Acetamiprid & Atrazine & Azoxystrobin & Clothianidin & Cyantraniliprole & Dinotefuran & Imidacloprid & Mefenoxam & Metolachlor & Thiacloprid & Thiamethoxam \\
\hline LP-MW-02-10 M & 0.0000 & 0.0000 & 0.0000 & 0.0000 & 0.0074 & 0.0000 & 0.0118 & 0.0000 & 0.0000 & 0.0000 & 0.0000 \\
\hline LP-MW-02-10 D & 0.0000 & 0.0000 & 0.0000 & 0.0000 & 0.0000 & 0.0000 & 0.0041 & 0.0000 & 0.0000 & 0.0000 & 0.0000 \\
\hline LP-MW-03-10 S & 0.0000 & 0.0000 & 0.0000 & 0.0000 & 0.0000 & 0.0000 & 0.0000 & 0.0000 & 0.0000 & 0.0000 & 0.0000 \\
\hline LP-MW-03-10 D & 0.0000 & 0.0000 & 0.0000 & 0.0000 & 0.0000 & 0.0000 & 0.0000 & 0.0000 & 0.0000 & 0.0000 & 0.0000 \\
\hline LP-MW-04-10 S & 0.0000 & 0.0000 & 0.0000 & 0.0000 & 0.0000 & 0.0000 & 0.0000 & 0.0000 & 0.0000 & 0.0000 & 0.0000 \\
\hline LP-MW-04-10 M & 0.0000 & 0.0000 & 0.0000 & 0.0000 & 0.0000 & 0.0000 & 0.0070 & 0.0000 & 0.0000 & 0.0000 & 0.0000 \\
\hline LP-MW-04-10 D & 0.0000 & 0.0000 & 0.0000 & 0.0000 & 0.0000 & 0.0000 & 0.0000 & 0.0000 & 0.0000 & 0.0000 & 0.0000 \\
\hline LP-MW-05-10 D & 0.0000 & 0.0000 & 0.0000 & 0.0000 & 0.0000 & 0.0000 & 0.0000 & 0.0000 & 0.0000 & 0.0000 & 0.0000 \\
\hline LP-MW-07-10 S & 0.0000 & 0.0000 & 0.0000 & 0.0000 & 0.0000 & 0.0000 & 0.0000 & 0.0000 & 0.0000 & 0.0000 & 0.0000 \\
\hline LP-MW-07-10 D & 0.0000 & 0.0000 & 0.0000 & 0.0000 & 0.0000 & 0.0000 & 0.0000 & 0.0000 & 0.0000 & 0.0000 & 0.0000 \\
\hline LP-MW-08-10 D & --- & --- & --- & --- & --- & --- & --- & --- & --- & --- & --- \\
\hline LP-MW-08-10 M & --- & --- & --- & --- & --- & --- & --- & --- & --- & --- & --- \\
\hline LP-MW-08-10 S & 0.0000 & 0.0000 & 0.0000 & 0.0000 & 0.0000 & 0.0000 & 0.0700 & 0.1090 & 0.0000 & 0.0000 & 0.0034 \\
\hline LP-MW-10-10 S & 0.0000 & 0.0000 & 0.0000 & 0.0000 & 0.0000 & 0.0000 & 0.0210 & 0.0000 & 0.0000 & 0.0000 & 0.0000 \\
\hline
\end{tabular}




\begin{tabular}{|c|c|c|c|c|c|c|c|c|c|c|c|}
\hline LP-MW-11-10 S & 0.0000 & 0.0000 & 0.0000 & 0.0000 & 0.0000 & 0.0000 & 0.0000 & 0.0000 & 0.0000 & 0.0000 & 0.0000 \\
\hline LP-MW-11-10 D & 0.0000 & 0.0000 & 0.0000 & 0.0000 & 0.0000 & 0.0000 & 0.0000 & 0.0000 & 0.0000 & 0.0000 & 0.0000 \\
\hline LP-MW-12-10 S & 0.0000 & 0.0000 & 0.0000 & 0.0000 & 0.0000 & 0.0000 & 0.0000 & 0.0000 & 0.0000 & 0.0000 & 0.0000 \\
\hline LP-MW-14-10 S & 0.0000 & 0.0000 & 0.0000 & 0.0000 & 0.0000 & 0.0000 & 0.0000 & 0.0000 & 0.0000 & 0.0000 & 0.0000 \\
\hline LP-MW-14-10 M & 0.0000 & 0.0000 & 0.0000 & 0.0000 & 0.0000 & 0.0000 & 0.0000 & 0.0000 & 0.0000 & 0.0000 & 0.0000 \\
\hline LP-MW-14-10 D & 0.0000 & 0.0000 & 0.0000 & 0.0000 & 0.0000 & 0.0000 & 0.0000 & 0.0000 & 0.0000 & 0.0000 & 0.0008 \\
\hline LP-MW-17-10 S & 0.0000 & 0.0000 & 0.0000 & 0.0000 & 0.0000 & 0.0000 & 0.0000 & 0.0000 & 0.1267 & 0.0000 & 0.0000 \\
\hline LP-MW-17-10 M14 & --- & --- & --- & --- & --- & --- & --- & --- & --- & --- & --- \\
\hline LP-MW-17-10 M26 & --- & --- & --- & --- & --- & --- & --- & --- & --- & --- & --- \\
\hline LP-MW-17-10 D & --- & --- & --- & --- & --- & --- & --- & --- & --- & --- & --- \\
\hline LP-MW-18-10 S & 0.0000 & 0.0000 & 0.0000 & 0.0000 & 0.0000 & 0.0000 & 0.0000 & 0.0000 & 0.0000 & 0.0000 & 0.0000 \\
\hline LP-MW-18-10 M & 0.0000 & 0.0000 & 0.0000 & 0.0000 & 0.0000 & 0.0000 & 0.0000 & 0.0000 & 0.0000 & 0.0000 & 0.0000 \\
\hline LP-MW-19-10 S & 0.0000 & 0.0000 & 0.0000 & 0.0000 & 0.0000 & 0.0000 & 0.0000 & 0.0000 & 0.0000 & 0.0000 & 0.0000 \\
\hline LP-MW-22-10 S & 0.0000 & 0.0000 & 0.0000 & 0.0000 & 0.0000 & 0.0000 & 0.0127 & 0.0000 & 0.0000 & 0.0000 & 0.0000 \\
\hline LP-MW-22-10 M & 0.0000 & 0.0000 & 0.0000 & 0.0000 & 0.0000 & 0.0000 & 0.0000 & 0.0000 & 0.0000 & 0.0000 & 0.0000 \\
\hline TW1 S & --- & --- & --- & --- & --- & --- & --- & -- & --- & --- & --- \\
\hline TW1 M & 0.0000 & 0.0486 & 0.0000 & 0.0000 & 0.0000 & 0.0000 & 0.0318 & 0.0000 & 0.0000 & 0.0000 & 0.0000 \\
\hline TW1 D & 0.0000 & 0.0560 & 0.0000 & 0.0000 & 0.0000 & 0.0000 & 0.0143 & 0.0000 & 0.0000 & 0.0000 & 0.0000 \\
\hline TW3 S & 0.0000 & 0.0000 & 0.0000 & 0.0000 & 0.0000 & 0.0000 & 0.0000 & 0.0000 & 0.0000 & 0.0000 & 0.0000 \\
\hline TW3D & --- & --- & --- & --- & --- & --- & --- & --- & --- & --- & --- \\
\hline TW4 S & --- & --- & --- & --- & --- & --- & --- & --- & --- & --- & --- \\
\hline TW4D & 0.0000 & 0.0000 & 0.0000 & 0.0000 & 0.0000 & 0.0000 & 0.0000 & 0.0000 & 0.1033 & 0.0000 & 0.0000 \\
\hline --- & --- & --- & --- & --- & --- & --- & --- & --- & --- & --- & --- \\
\hline TW5 S & 0.0000 & 0.0428 & 0.0000 & 0.0000 & 0.0000 & 0.0000 & 0.0000 & 0.0000 & 0.0000 & 0.0000 & 0.0000 \\
\hline TW6 S & 0.0000 & 0.0000 & 0.0000 & 0.0000 & 0.0000 & 0.0000 & 0.0055 & 0.0000 & 0.0000 & 0.0000 & 0.0000 \\
\hline TW7 S & 0.0000 & 0.0000 & 0.0000 & 0.0000 & 0.0000 & 0.0000 & 0.0074 & 0.0000 & 0.0000 & 0.0000 & 0.0000 \\
\hline TW7M & 0.0000 & 0.0078 & 0.0000 & 0.0000 & 0.0000 & 0.0000 & 0.0000 & 0.0000 & 0.0000 & 0.0000 & 0.0000 \\
\hline TW7 D & 0.0000 & 0.0014 & 0.0000 & 0.0000 & 0.0000 & 0.0000 & 0.0105 & 0.0000 & 0.0000 & 0.0000 & 0.0000 \\
\hline TW8 (open) & 0.0000 & 0.0000 & 0.0000 & 0.0000 & 0.0000 & 0.0000 & 0.0000 & 0.0000 & 0.0000 & 0.0000 & 0.0000 \\
\hline TW9 S & 0.0000 & 0.0000 & 0.0000 & 0.0000 & 0.0000 & 0.0000 & 0.0000 & 0.0000 & 0.0000 & 0.0000 & 0.0000 \\
\hline TW11 S & --- & --- & --- & --- & --- & --- & --- & --- & --- & --- & --- \\
\hline
\end{tabular}




\begin{tabular}{|c|c|c|c|c|c|c|c|c|c|c|c|}
\hline TW11 M & 0.0000 & 0.0000 & 0.0000 & 0.0000 & 0.0000 & 0.0000 & 0.0000 & 0.0000 & 0.0000 & 0.0000 & 0.0000 \\
\hline TW11D & 0.0000 & 0.0000 & 0.0000 & 0.0000 & 0.0000 & 0.0000 & 0.0000 & 0.0000 & 0.0000 & 0.0000 & 0.0000 \\
\hline TW13 S & --- & --- & --- & --- & --- & --- & --- & --- & --- & --- & --- \\
\hline TW13 M & --- & --- & --- & --- & --- & --- & --- & --- & --- & --- & --- \\
\hline TW13 D & --- & --- & --- & --- & --- & --- & --- & --- & --- & --- & --- \\
\hline TW16 S & 0.0000 & 0.0000 & 0.0000 & 0.0000 & 0.0000 & 0.0000 & 0.0000 & 0.0000 & 0.0000 & 0.0000 & 0.0000 \\
\hline TW16 M & 0.0000 & 0.0000 & 0.0000 & 0.0000 & 0.0000 & 0.0000 & 0.0000 & 0.0000 & 0.0000 & 0.0000 & 0.0000 \\
\hline TW17 (open) & 0.0000 & 0.1800 & 0.0000 & 0.0000 & 0.0000 & 0.0000 & 0.0000 & 0.0000 & 0.0000 & 0.0000 & 0.0605 \\
\hline TW18 S & 0.0000 & 0.0000 & 0.0000 & 0.0000 & 0.0000 & 0.0000 & 0.0000 & 0.0000 & 0.0000 & 0.0000 & 0.0000 \\
\hline TW19 S & 0.0000 & 0.0000 & 0.0000 & 0.0000 & 0.0000 & 0.0000 & 0.0000 & 0.0000 & 0.0000 & 0.0000 & 0.0000 \\
\hline TW19 M & --- & --- & --- & --- & --- & --- & --- & --- & --- & --- & --- \\
\hline TW19 D & 0.0000 & 0.0000 & 0.0000 & 0.0000 & 0.0000 & 0.0000 & 0.0000 & 0.0000 & 0.0000 & 0.0000 & 0.0000 \\
\hline TW20 (open) & 0.0000 & 0.0007 & 0.0000 & 0.0000 & 0.0000 & 0.0000 & 0.0000 & 0.0000 & 0.0000 & 0.0000 & 0.0000 \\
\hline $\operatorname{LOD}(\mu \mathrm{g} / \mathrm{L})$ & 0.0163 & 0.0030 & 0.0020 & 0.1171 & 0.0121 & 0.0069 & 0.0221 & 0.0043 & 0.0254 & 0.0023 & 0.0095 \\
\hline LOQ $(\mu \mathrm{g} / \mathrm{L})$ & 0.0482 & 0.0077 & 0.0051 & 0.2755 & 0.0342 & 0.0187 & 0.0664 & 0.0102 & 0.0577 & 0.0066 & 0.0276 \\
\hline
\end{tabular}

Neonicotinoid(s) above LOQ

Neonicotinoid(s) above LOD but below LOQ

All neonicotinoids below LOD 


\begin{tabular}{|c|c|c|c|c|c|c|c|c|c|c|c|}
\hline \multirow[b]{2}{*}{ Well Label } & \multicolumn{11}{|c|}{ August 2016 Field Data for Norfolk County } \\
\hline & Date & Time & $\begin{array}{l}\text { Depth to } \\
\text { Water } \\
\text { (m) }\end{array}$ & $\begin{array}{c}\text { Temperature } \\
\left({ }^{\circ} \mathrm{C}\right)\end{array}$ & $\begin{array}{l}\text { Conductivity } \\
\left(\mathrm{mS} / \mathrm{cm}^{2}\right)\end{array}$ & $\begin{array}{c}\mathrm{DO} \\
(\mathrm{mg} / \mathrm{L})\end{array}$ & $\mathrm{pH}$ & ORP & $\begin{array}{l}\text { Nitrate } \\
\text { (mg/L) }\end{array}$ & $\begin{array}{l}\text { Water } \\
\text { Quality }\end{array}$ & $\begin{array}{c}\text { Water } \\
\text { Quantity }\end{array}$ \\
\hline LP-MW-02-10 M & $17 / 08 / 2016$ & 0925 & 10.20 & 10.84 & 0.857 & 6.90 & 7.39 & -23.20 & 6.78 & Clear & High \\
\hline LP-MW-02-10 D & $17 / 08 / 2016$ & 0940 & 10.13 & 10.83 & 0.848 & 6.21 & 6.41 & -24.20 & 6.23 & Clear & High \\
\hline LP-MW-03-10 S & 17/08/2016 & 1625 & 6.43 & 12.12 & 0.685 & 12.01 & 7.56 & -39.60 & 20.72 & Clear & High \\
\hline LP-MW-03-10 D & $17 / 08 / 2016$ & 1555 & 6.66 & 11.51 & 0.686 & 2.45 & 7.47 & -45.10 & 0.12 & Clear & High flow \\
\hline LP-MW-04-10 S & 17/08/2016 & 1315 & 4.68 & 12.30 & 1.171 & 8.86 & 7.4 & -23.70 & 13.52 & Clear & High flow \\
\hline LP-MW-04-10 M & 17/08/2016 & 1350 & 4.68 & 11.20 & 0.724 & 7.29 & 7.42 & -39.40 & 8.01 & Clear & High \\
\hline LP-MW-04-10 D & $17 / 08 / 2016$ & 1425 & 4.80 & 11.07 & 0.681 & 2.32 & 7.52 & -42.50 & 0.56 & Clear & High \\
\hline LP-MW-05-10 D & $17 / 08 / 2016$ & 1040 & 4.10 & 10.47 & 0.497 & 2.33 & 7.56 & -47.90 & 0.00 & Brown silty-sand & Moderate-high \\
\hline LP-MW-07-10 S & $17 / 08 / 2016$ & 1145 & 6.03 & 10.92 & 0.768 & 8.55 & 7.36 & -36.50 & 0.00 & Clear & High \\
\hline LP-MW-07-10 D & $17 / 08 / 2016$ & 1225 & 6.10 & 10.94 & 0.653 & 2.24 & 7.39 & -39.70 & 0.14 & Clear & High \\
\hline LP-MW-08-10 S & 18/08/2016 & 1820 & 3.60 & 13.60 & 1.368 & 8.98 & 7.65 & 269.70 & 21.56 & Dark grey & Low-moderate \\
\hline LP-MW-08-10 M & 18/08/2016 & 1800 & 4.23 & 13.05 & 0.447 & 2.19 & 7.63 & 268.70 & 1.38 & Cloudy & Low \\
\hline LP-MW-08-10 D & 18/08/2016 & 1735 & 4.30 & 13.42 & 0.237 & 3.03 & 8.87 & 204.70 & 0.30 & Cloudy & Low \\
\hline LP-MW-10-10 S & 18/08/2016 & 1110 & 2.77 & 10.88 & 0.812 & 2.32 & 2.08 & 203.40 & 0.15 & Goldish & High flow \\
\hline LP-MW-11-10 S & $17 / 08 / 2016$ & 1810 & 4.97 & 9.68 & 0.536 & 13.19 & 7.46 & -29.70 & 0.13 & Cloudy & High \\
\hline LP-MW-11-10 D & $17 / 08 / 2016$ & 1725 & 5.13 & 10.29 & 0.447 & 2.73 & 7.72 & -49.80 & 0.00 & Greyish fine sand & Moderate-high \\
\hline LP-MW-12-10 S & 18/08/2016 & 1025 & 3.89 & 12.14 & 0.576 & 5.40 & 7.46 & -39.90 & 4.10 & Brown & High \\
\hline LP-MW-14-10 S & 18/08/2016 & 1630 & 3.78 & 11.80 & 0.702 & 5.74 & 7.79 & 234.50 & 2.77 & Cloudy & High \\
\hline LP-MW-14-10 M & 18/08/2016 & 1600 & 3.80 & 11.62 & 1.281 & 12.03 & 8.61 & 150.60 & 0.10 & Clear & Moderate-high \\
\hline LP-MW-14-10 D & $18 / 08 / 2016$ & 1530 & 4.62 & 11.26 & 0.341 & 2.29 & 10.13 & 94.80 & 0.09 & Clear & High \\
\hline LP-MW-17-10 S & $17 / 08 / 2016$ & 1935 & 4.00 & 13.86 & 3.453 & 8.81 & 7.16 & -4.20 & 10.73 & Light brown & Low-moderate \\
\hline LP-MW-17-10 M14 & --- & --- & --- & --- & --- & --- & --- & --- & --- & --- & --- \\
\hline LP-MW-17-10 M26 & --- & --- & --- & --- & --- & --- & --- & --- & --- & --- & --- \\
\hline LP-MW-17-10 D & $17 / 08 / 2016$ & 1905 & 4.07 & 11.46 & 0.278 & 21.40 & 8.23 & $10 \overline{4} .20$ & 0.00 & $\begin{array}{l}\text { Cloudy. Silty- } \\
\text { sand in bucket }\end{array}$ & Moderate \\
\hline
\end{tabular}




\begin{tabular}{|c|c|c|c|c|c|c|c|c|c|c|c|}
\hline LP-MW-18-10 S & $18 / 08 / 2016$ & 1400 & 3.87 & 13.43 & 0.794 & 11.04 & 10.91 & 82.10 & 2.30 & Cloudt & High \\
\hline LP-MW-18-10 M & $18 / 08 / 2016$ & 1335 & 3.8 & 11.96 & 1.325 & 2.55 & 11.17 & 90.30 & 1.30 & Clear & High \\
\hline LP-MW-19-10 S & $18 / 08 / 2016$ & 1440 & 2.27 & 12.11 & 0.701 & 2.26 & 11.62 & 65.90 & 0.13 & Greenish & High \\
\hline LP-MW-22-10 S & $18 / 08 / 2016$ & 1910 & 2.63 & 12.47 & 1.383 & 2.13 & 10.45 & -4.00 & 0.26 & Yellowish & Low-moderate \\
\hline LP-MW-22-10 M & $18 / 08 / 2016$ & --- & 2.61 & --- & --- & --- & --- & --- & --- & --- & --- \\
\hline
\end{tabular}

\begin{tabular}{|c|c|c|c|c|c|c|c|c|c|c|c|}
\hline \multirow[b]{2}{*}{ Well Label } & \multicolumn{11}{|c|}{ August 2016 Field Data for Lanark County } \\
\hline & Date & Time & $\begin{array}{l}\text { Depth to } \\
\text { Water } \\
\text { (m) }\end{array}$ & $\begin{array}{c}\text { Temperature } \\
\left({ }^{\circ} \mathrm{C}\right)\end{array}$ & $\begin{array}{c}\text { Conductivity } \\
\left(\mathrm{mS} / \mathrm{cm}^{2}\right)\end{array}$ & $\begin{array}{c}\mathrm{DO} \\
(\mathrm{mg} / \mathrm{L})\end{array}$ & $\mathrm{pH}$ & ORP & $\begin{array}{l}\text { Nitrate } \\
\text { (mg/L) }\end{array}$ & $\begin{array}{l}\text { Water } \\
\text { Quality }\end{array}$ & $\begin{array}{c}\text { Water } \\
\text { Quantity }\end{array}$ \\
\hline TW1S & $09 / 08 / 2016$ & --- & Dry & --- & $\begin{array}{ll}-- \\
\end{array}$ & $\begin{array}{ll}-- \\
\end{array}$ & $\begin{array}{ll}-- \\
\end{array}$ & $\begin{array}{ll}-- \\
\end{array}$ & $\begin{array}{ll}-- \\
\end{array}$ & $\begin{array}{ll}-- \\
\end{array}$ & $\begin{array}{ll}-- \\
\end{array}$ \\
\hline TW1 M & 09/08/2016 & 1359 & 6.05 & 12.95 & 0.956 & 7.10 & 7.34 & 16.80 & 2.10 & Clear & Medium \\
\hline TW1 D & 09/08/2016 & 1435 & 6.30 & 12.53 & 1.080 & 3.49 & 7.27 & 14.50 & 1.34 & Clear & Medium \\
\hline TW3 S & 10/08/2016 & --- & 6.49 & --- & --- & --- & --- & --- & --- & --- & --- \\
\hline TW3D & $10 / 08 / 2016$ & --- & 6.22 & --- & --- & --- & --- & --- & --- & --- & --- \\
\hline TW4 S & 10/08/2016 & --- & 3.27 & --- & --- & --- & --- & --- & --- & --- & --- \\
\hline TW4D & 10/08/2016 & 1027 & 3.10 & 12.20 & 0.990 & 5.53 & 7.61 & -18.20 & 0.00 & Brownish & Extremely low (bailer used) \\
\hline River near TW4 & $10 / 08 / 2016$ & 1202 & --- & 26.33 & 0.293 & 9.03 & 8.48 & -35.50 & --- & --- & High river flow \\
\hline TW5 S & 09/08/2016 & 1515 & 5.19 & 12.63 & 0.813 & 7.81 & 7.19 & 16.70 & 0.88 & Clear & Medium \\
\hline TW6 S & 09/08/2016 & 1556 & 4.67 & 9.99 & 0.780 & 10.17 & 7.14 & 101.10 & 0.61 & Clear & Very high \\
\hline TW7 S & 09/08/2016 & 1233 & 6.30 & 11.40 & 0.965 & 2.96 & 6.88 & 30.00 & 0.12 & Clear & High \\
\hline TW7M & 09/08/2016 & 1246 & 6.30 & 11.30 & 1.023 & 3.64 & 7.12 & 23.10 & 0.12 & Clear & High \\
\hline TW7 D & 09/08/2016 & 1310 & 6.30 & 10.96 & 1.083 & 6.46 & 7.15 & 27.00 & 1.10 & Clear & High \\
\hline TW8 (open) & 09/08/2016 & 1632 & 6.14 & 10.06 & 0.934 & 7.10 & 7.21 & 26.20 & 0.61 & Clear & High \\
\hline TW9 S & 09/08/2016 & 1128 & 2.69 & 13.40 & 1.327 & 2.68 & 7.07 & 19.30 & 0.18 & Clear & Low \\
\hline TW11 S & 10/08/2016 & --- & 3.10 & --- & --- & --- & --- & --- & --- & --- & --- \\
\hline TW11 M & $10 / 08 / 2016$ & 1408 & 3.15 & 19.45 & 1.542 & 1.50 & 7.13 & 43.00 & 0.14 & Clear & Very low \\
\hline TW11D & 10/08/2016 & 1507 & 3.15 & 18.54 & 1.509 & 1.70 & 7.29 & -2.00 & 0.10 & Clear & Very low \\
\hline TW13 S & $11 / 08 / 2016$ & --- & 3.05 & --- & --- & --- & --- & --- & --- & --- & --- \\
\hline
\end{tabular}




\begin{tabular}{|c|c|c|c|c|c|c|c|c|c|c|c|}
\hline TW13 M & $11 / 08 / 2016$ & 1242 & 3.05 & 13.59 & 0.671 & 5.11 & 7.65 & -28.00 & 0.22 & Clear & Low-moderate \\
\hline TW13 D & $11 / 08 / 2016$ & 1200 & 3.05 & 10.23 & 0.611 & 6.72 & 7.66 & 16.10 & 0.18 & Clear & High \\
\hline TW16 S & $11 / 08 / 2016$ & --- & 1.86 & --- & --- & --- & --- & --- & --- & --- & --- \\
\hline TW16 M & 11/08/2016 & 1036 & 1.86 & 11.77 & 1.598 & 2.69 & 7.4 & 73.10 & 0.07 & Clear & Low-moderate \\
\hline TW17 (open) & 11/08/2016 & 1010 & 3.24 & 12.51 & 1.349 & 2.60 & 7.26 & 33.20 & 5.73 & Clear & Moderate-high \\
\hline TW18 S & 11/08/2016 & 1340 & 3.17 & 1432.00 & 1.030 & 2.36 & 6.95 & 24.20 & 0.08 & Clear & Moderate \\
\hline TW19 S & 09/08/2016 & 9.36 & 3.10 & 15.17 & 1.157 & 3.44 & 7.18 & 56.90 & 0.14 & Clear & High \\
\hline TW19 M & 09/08/2016 & 1010 & 2.67 & 12.53 & 1.062 & 2.49 & 7.53 & 55.50 & 0.06 & Clear & Low \\
\hline TW19 D & 09/08/2016 & 1041 & 2.67 & 11.63 & 1.081 & 2.39 & 7.56 & -46.90 & 0.06 & Clear & Low \\
\hline TW20 (open) & 10/08/2016 & 1132 & 6.19 & 14.84 & 0.603 & 2.09 & 6.84 & 28.10 & 0.23 & Clear & Low-moderate \\
\hline TW21S & $11 / 08 / 2016$ & 1420 & 4.09 & 13.67 & 1.219 & 2.89 & 8.09 & -60.00 & 0.11 & Brownish & Low \\
\hline TW21M & $11 / 08 / 2016$ & 1451 & 4.09 & 11.91 & 3.581 & 2.28 & 6.83 & 2.40 & 0.32 & Brownish & Low \\
\hline TW21D & $11 / 08 / 2016$ & --- & 3.70 & --- & --- & --- & --- & --- & --- & --- & --- \\
\hline River near TW21 & $11 / 08 / 2016$ & 1504 & --- & 30.12 & 0.294 & 8.19 & 8.73 & -96.00 & --- & --- & --- \\
\hline
\end{tabular}

\begin{tabular}{|c|c|c|c|c|c|c|c|c|c|c|c|}
\hline \multicolumn{12}{|c|}{ August 2016 Sample Analysis for Norfolk and Lanark County ( $\mu g / L)$} \\
\hline Well Label & Acetamiprid & Atrazine & Azoxystrobin & Clothianidin & Cyantraniliprole & Dinotefuran & n Imidacloprid & Mefenoxam & Metolachlor & Thiacloprid & Thiamethoxam \\
\hline LP-MW-02-10 M & 0.0000 & 0.0000 & 0.0175 & 0.0000 & 0.0000 & 0.0000 & 0.0000 & 0.0000 & 0.0000 & 0.0000 & 0.0000 \\
\hline LP-MW-02-10 D & 0.0000 & 0.0000 & 0.0226 & 1.6843 & 0.0000 & 0.0000 & 0.0000 & 0.0000 & 0.0000 & 0.0000 & 0.0000 \\
\hline LP-MW-03-10 S & 0.0000 & 0.0000 & 0.0220 & 0.0098 & 0.0007 & 0.0000 & 0.0000 & 0.0047 & 0.3271 & 0.0000 & 0.0000 \\
\hline LP-MW-03-10 D & 0.0000 & 0.0000 & 0.0201 & 0.0280 & 0.0000 & 0.0000 & 0.0000 & 0.0000 & 0.0000 & 0.0000 & 0.0000 \\
\hline LP-MW-04-10 S & 0.0000 & 0.0000 & 0.0178 & 0.0047 & 0.0000 & 0.0000 & 0.0000 & 0.0000 & 0.0000 & 0.0000 & 0.0000 \\
\hline LP-MW-04-10 M & 0.0000 & 0.0000 & 0.0177 & 0.0000 & 0.0000 & 0.0000 & 0.0000 & 0.0000 & 0.0000 & 0.0000 & 0.0000 \\
\hline LP-MW-04-10 D & 0.0000 & 0.0000 & 0.0172 & 0.0031 & 0.0000 & 0.0000 & 0.0000 & 0.0000 & 0.0000 & 0.0000 & 0.0000 \\
\hline LP-MW-05-10 D & 0.0000 & 0.0000 & 0.0175 & 0.0174 & 0.0000 & 0.0000 & 0.0000 & 0.0000 & 0.0000 & 0.0000 & 0.0000 \\
\hline LP-MW-07-10 S & 0.0000 & 0.0000 & 0.0196 & 0.0285 & 0.0000 & 0.0000 & 0.0000 & 0.0000 & 0.0110 & 0.0000 & 0.0000 \\
\hline LP-MW-07-10 D & 0.0000 & 0.0000 & 0.0177 & 0.0048 & 0.0000 & 0.0000 & 0.0000 & 0.0000 & 0.0000 & 0.0000 & 0.0000 \\
\hline LP-MW-08-10 S & 0.0000 & 0.0000 & 0.0191 & 0.0091 & 0.0000 & 0.0000 & 0.0309 & 0.1159 & 0.0000 & 0.0000 & 0.0000 \\
\hline LP-MW-08-10 M & 0.0000 & 0.0000 & 0.0186 & 0.0005 & 0.0024 & 0.0000 & 0.0000 & 0.0000 & 0.0000 & 0.0000 & 0.0000 \\
\hline
\end{tabular}




\begin{tabular}{|c|c|c|c|c|c|c|c|c|c|c|c|}
\hline LP-MW-08-10 D & 0.0000 & 0.0000 & 0.0240 & 2.0933 & 0.0018 & 0.0000 & 0.0000 & 0.0000 & 0.0000 & 0.0000 & 0.0000 \\
\hline LP-MW-10-10 S & 0.0000 & 0.0000 & 0.0195 & 0.0186 & 0.0000 & 0.0000 & 0.0000 & 0.0055 & 0.0000 & 0.0000 & 0.0000 \\
\hline LP-MW-11-10 S & 0.0000 & 0.0000 & 0.0178 & 0.0298 & 0.0000 & 0.0000 & 0.0000 & 0.0000 & 0.0000 & 0.0000 & 0.0000 \\
\hline LP-MW-11-10 D & 0.0000 & 0.0000 & 0.0230 & 1.6727 & 0.0000 & 0.0000 & 0.0000 & 0.0000 & 0.0000 & 0.0000 & 0.0000 \\
\hline LP-MW-12-10 S & 0.0000 & 0.0000 & 0.0199 & 0.0251 & 0.0000 & 0.0000 & 0.0000 & 0.0000 & 0.0000 & 0.0000 & 0.0113 \\
\hline LP-MW-14-10 S & 0.0000 & 0.0000 & 0.0192 & 0.0107 & 0.0000 & 0.0000 & 0.0000 & 0.0066 & 0.0000 & 0.0000 & 0.0000 \\
\hline LP-MW-14-10 M & 0.0000 & 0.0000 & 0.0197 & 0.0065 & 0.0000 & 0.0000 & 0.0000 & 0.0000 & 0.0000 & 0.0000 & 0.0000 \\
\hline LP-MW-14-10 D & 0.0000 & 0.0000 & 0.0176 & 0.0000 & 0.0000 & 0.0000 & 0.0000 & 0.0000 & 0.0050 & 0.0000 & 0.0000 \\
\hline LP-MW-17-10 S & 0.0000 & 0.0000 & 0.0181 & 0.0015 & 0.0000 & 0.0000 & 0.0000 & 0.0000 & 0.0000 & 0.0000 & 0.0000 \\
\hline LP-MW-17-10 M14 & --- & --- & --- & --- & --- & --- & --- & --- & --- & --- & --- \\
\hline LP-MW-17-10 M26 & --- & --- & --- & --- & --- & --- & --- & --- & --- & --- & --- \\
\hline LP-MW-17-10 D & 0.0000 & 0.0000 & 0.0174 & 0.0010 & 0.0000 & 0.0000 & 0.0000 & 0.0000 & 0.0000 & 0.0000 & 0.0000 \\
\hline LP-MW-18-10 S & 0.0000 & 0.0000 & 0.0200 & 0.0321 & 0.0000 & 0.0000 & 0.0000 & 0.0101 & 0.0000 & 0.0000 & 0.0000 \\
\hline LP-MW-18-10 M & 0.0000 & 0.0000 & 0.0195 & 0.0000 & 0.0000 & 0.0000 & 0.0000 & 0.0000 & 0.0000 & 0.0000 & 0.0000 \\
\hline LP-MW-19-10 S & 0.0000 & 0.0000 & 0.0185 & 0.0259 & 0.0000 & 0.0000 & 0.0000 & 0.0000 & 0.0000 & 0.0000 & 0.0000 \\
\hline LP-MW-22-10 S & 0.0000 & 0.0000 & 0.0193 & 0.0212 & 0.0000 & 0.0000 & 0.0000 & 0.0000 & 0.0000 & 0.0000 & 0.0000 \\
\hline LP-MW-22-10 M & --- & --- & --- & --- & --- & --- & --- & --- & --- & --- & --- \\
\hline TW1S & --- & --- & --- & --- & --- & --- & --- & --- & --- & --- & --- \\
\hline TW1 M & 0.0000 & 0.0793 & 0.0171 & 0.0000 & 0.0000 & 0.0000 & 0.0000 & 0.0000 & 0.0000 & 0.0000 & 0.0000 \\
\hline TW1 D & 0.0000 & 0.0946 & 0.0199 & 1.1627 & 0.0010 & 0.0000 & 0.0000 & 0.0000 & 0.0039 & 0.0000 & 0.0000 \\
\hline TW3 S & --- & --- & --- & --- & --- & --- & --- & --- & --- & --- & --- \\
\hline TW3D & --- & --- & --- & --- & --- & --- & --- & --- & --- & --- & --- \\
\hline TW4 S & --- & --- & --- & --- & --- & --- & --- & --- & --- & --- & --- \\
\hline TW4D & 0.0000 & 0.0000 & 0.0179 & 0.0199 & 0.0002 & 0.0000 & 0.0000 & 0.0000 & 0.0000 & 0.0000 & 0.0000 \\
\hline River near TW4 & 0.0000 & 0.0019 & 0.0200 & 0.0000 & 0.0000 & 0.0000 & 0.0000 & 0.0002 & 0.0000 & 0.0000 & 0.0000 \\
\hline TW5 S & 0.0000 & 0.0000 & 0.0165 & 0.0200 & 0.0000 & 0.0000 & 0.0000 & 0.0000 & 0.0000 & 0.0000 & 0.0000 \\
\hline TW6 S & 0.0000 & 0.0000 & 0.0172 & 0.0135 & 0.0000 & 0.0000 & 0.0000 & 0.0000 & 0.0000 & 0.0000 & 0.0000 \\
\hline TW7 S & 0.0000 & 0.0125 & 0.0167 & 0.0000 & 0.0000 & 0.0000 & 0.0000 & 0.0000 & 0.0000 & 0.0000 & 0.0000 \\
\hline TW7M & 0.0000 & 0.0053 & 0.0181 & 0.0139 & 0.0000 & 0.0000 & 0.0000 & 0.0000 & 0.0000 & 0.0000 & 0.0000 \\
\hline TW7 D & 0.0000 & 0.0072 & 0.0174 & 0.0000 & 0.0000 & 0.0000 & 0.0000 & 0.0000 & 0.0000 & 0.0000 & 0.0000 \\
\hline
\end{tabular}




\begin{tabular}{|c|c|c|c|c|c|c|c|c|c|c|c|}
\hline TW8 (open) & 0.0000 & 0.0000 & 0.0187 & 0.0275 & 0.0018 & 0.0000 & 0.0000 & 0.0000 & 0.0000 & 0.0000 & 0.0000 \\
\hline TW9 S & 0.0000 & 0.0000 & 0.0190 & 0.0067 & 0.0000 & 0.0000 & 0.0000 & 0.0015 & 0.0137 & 0.0000 & 0.0000 \\
\hline TW11 S & --- & --- & --- & --- & --- & --- & --- & --- & --- & --- & --- \\
\hline TW11 M & 0.0000 & 0.0000 & 0.0197 & 0.0000 & 0.0000 & 0.0000 & 0.0000 & 0.0000 & 0.0000 & 0.0000 & 0.0000 \\
\hline TW11D & 0.0000 & 0.0000 & 0.0192 & 0.0264 & 0.0000 & 0.0000 & 0.0033 & 0.0000 & 0.0000 & 0.0000 & 0.0000 \\
\hline TW13 S & --- & --- & --- & --- & --- & --- & --- & --- & --- & --- & --- \\
\hline TW13 M & 0.0000 & 0.0000 & 0.0176 & 0.0000 & 0.0000 & 0.0000 & 0.0000 & 0.0000 & 0.0000 & 0.0000 & 0.0000 \\
\hline TW13 D & 0.0000 & 0.0000 & 0.0175 & 0.0000 & 0.0010 & 0.0000 & 0.0000 & 0.0000 & 0.0000 & 0.0000 & 0.0000 \\
\hline TW16 S & --- & --- & --- & --- & --- & --- & --- & --- & --- & --- & --- \\
\hline TW16 M & 0.0000 & 0.0000 & 0.0174 & 0.0040 & 0.0000 & 0.0000 & 0.0000 & 0.0000 & 0.0000 & 0.0000 & 0.0000 \\
\hline TW17 (open) & 0.0000 & 0.3993 & 0.0172 & 0.0124 & 0.0000 & 0.0000 & 0.0000 & 0.0000 & 0.0000 & 0.0000 & 0.0090 \\
\hline TW18 S & 0.0000 & 0.0000 & 0.0177 & 0.0000 & 0.0000 & 0.0000 & 0.0000 & 0.0000 & 0.0000 & 0.0000 & 0.0000 \\
\hline TW19 S & 0.0000 & 0.0000 & 0.0186 & 0.0310 & 0.0000 & 0.0000 & 0.0000 & 0.0000 & 0.0210 & 0.0000 & 0.0000 \\
\hline TW19 M & 0.0000 & 0.0000 & 0.0168 & 0.0051 & 0.0000 & 0.0000 & 0.0000 & 0.0000 & 0.0000 & 0.0000 & 0.0000 \\
\hline TW19 D & 0.0000 & 0.0000 & 0.0178 & 0.0233 & 0.0000 & 0.0000 & 0.0000 & 0.0000 & 0.0000 & 0.0000 & 0.0000 \\
\hline TW20 (open) & 0.0000 & 0.0031 & 0.0185 & 0.0108 & 0.0000 & 0.0000 & 0.0000 & 0.0000 & 0.0000 & 0.0000 & 0.0000 \\
\hline TW21S & 0.0000 & 0.0000 & 0.0178 & 0.0087 & 0.0000 & 0.0000 & 0.0000 & 0.0000 & 0.0000 & 0.0000 & 0.0000 \\
\hline TW21M & 0.0000 & 0.0000 & 0.0173 & 0.0000 & 0.0000 & 0.0000 & 0.0000 & 0.0000 & 0.0000 & 0.0000 & 0.0000 \\
\hline TW21D & --- & --- & --- & --- & --- & --- & --- & --- & --- & --- & --- \\
\hline River near TW21 & 0.0000 & 0.0000 & 0.0188 & 0.0214 & 0.0000 & 0.0000 & 0.0000 & 0.0000 & 0.0000 & 0.0000 & 0.0000 \\
\hline LOD $(\mu \mathrm{g} / \mathrm{L})$ & 0.0030 & 0.0041 & 0.0252 & 0.0329 & 0.0040 & 0.0051 & 0.0101 & 0.0040 & 0.0161 & 0.0030 & 0.0066 \\
\hline LOQ $(\mu \mathrm{g} / \mathrm{L})$ & 0.0083 & 0.0103 & 0.0063 & 0.0828 & 0.0105 & 0.0137 & 0.0298 & 0.0092 & 0.0359 & 0.0079 & 0.0179 \\
\hline
\end{tabular}

Neonicotinoid(s) above LOQ

Neonicotinoid(s) above LOD but below LOQ

All neonicotinoids below LOD 


\begin{tabular}{|c|c|c|c|c|c|c|c|c|c|c|c|}
\hline \multirow[b]{2}{*}{ Well Label } & \multicolumn{11}{|c|}{ November 2016 Field Data for Norfolk County } \\
\hline & Date & Time & $\begin{array}{l}\text { Depth to } \\
\text { Water } \\
\text { (m) }\end{array}$ & \begin{tabular}{|c|} 
Temperature \\
$\left({ }^{\circ} \mathrm{C}\right)$ \\
\end{tabular} & $\begin{array}{c}\text { Conductivity } \\
\left(\mathrm{mS} / \mathrm{cm}^{2}\right)\end{array}$ & $\begin{array}{c}\mathrm{DO} \\
(\mathrm{mg} / \mathrm{L})\end{array}$ & $\mathrm{pH}$ & ORP & $\begin{array}{l}\text { Nitrate } \\
\text { (mg/L) }\end{array}$ & $\begin{array}{l}\text { Water } \\
\text { Quality }\end{array}$ & $\begin{array}{c}\text { Water } \\
\text { Quantity }\end{array}$ \\
\hline LP-MW-02-10 M & $02 / 11 / 2016$ & 1300 & 10.34 & 10.79 & 1.289 & 7.05 & 7.37 & -127.40 & 6.75 & Clear & Moderate-high \\
\hline LP-MW-02-10 D & 02/11/2016 & 1230 & 10.28 & 10.73 & 1.274 & 6.18 & 7.38 & 134.90 & 5.94 & Clear & Moderate-high \\
\hline LP-MW-03-10 S & 02/11/2016 & 1410 & 6.66 & 12.67 & 1.030 & 12.16 & 7.50 & -101.70 & 17.20 & Clear & High \\
\hline LP-MW-03-10 D & 02/11/2016 & 1435 & 6.91 & 10.96 & 1.018 & 2.61 & 7.44 & -104.60 & 0.12 & Clear & Moderate-high \\
\hline LP-MW-04-10 S & 02/11/2016 & 1524 & 4.85 & 12.97 & 1.375 & 9.40 & 7.43 & -83.60 & 17.60 & Clear & High \\
\hline LP-MW-04-10 M & $02 / 11 / 2016$ & 1600 & 4.88 & 10.64 & 1.063 & 6.29 & 7.41 & -30.50 & 7.60 & Clear & High \\
\hline LP-MW-04-10 D & 02/11/2016 & 1645 & 4.95 & 10.40 & 1.005 & 2.03 & 7.49 & -32.60 & 0.11 & Clear & High \\
\hline LP-MW-05-10 D & $04 / 11 / 2016$ & 0945 & 4.36 & 9.41 & 0.752 & 4.90 & 7.52 & 248.80 & 0.00 & Very silty & High \\
\hline LP-MW-07-10 S & 03/11/2016 & 0955 & 6.27 & 11.22 & 1.177 & 8.94 & 7.31 & -51.40 & 2.41 & Clear & Moderate-high \\
\hline LP-MW-07-10 D & 03/11/2016 & $1740^{*}$ & 6.34 & 9.93 & 0.919 & 2.44 & 7.38 & 222.60 & 0.12 & Clear & High \\
\hline LP-MW-08-10 S & 03/11/2016 & 1335 & 4.26 & 13.78 & 1.135 & 7.62 & 7.58 & -81.00 & 0.00 & Clear & High \\
\hline LP-MW-08-10 M & 03/11/2016 & 1300 & 4.17 & 11.02 & 0.668 & 4.67 & 7.60 & -77.50 & 0.00 & Dirty & Moderate \\
\hline LP-MW-08-10 D & 03/11/2016 & 1225 & 3.72 & 10.46 & 0.465 & 3.65 & 8.02 & -97.50 & 0.00 & Very dirty & Extremely low \\
\hline LP-MW-10-10 S & 02/11/2016 & 1000 & 2.73 & 11.88 & 1.242 & 4.13 & 7.11 & -47.30 & --- & Clear & High \\
\hline LP-MW-11-10 S & 03/11/2016 & 1545 & 5.33 & 9.44 & 0.804 & 13.76 & 7.46 & -127.10 & 0.18 & Goldish & High \\
\hline LP-MW-11-10 D & 03/11/2016 & 1525 & 5.47 & 9.41 & 0.684 & 2.56 & 7.69 & -86.20 & 0.12 & Greyish & High \\
\hline LP-MW-12-10 S & $01 / 11 / 2016$ & 1035 & 4.01 & 15.54 & 0.887 & 5.39 & 7.43 & -62.90 & 6.62 & Dirty & Low (likely pump issue) \\
\hline LP-MW-14-10 S & $04 / 11 / 2016$ & 1325 & 4.01 & 12.23 & 1.071 & 5.82 & 7.56 & 246.20 & 1.60 & Cloudy & High \\
\hline LP-MW-14-10 M & 04/11/2016 & 1255 & 4.04 & 10.57 & 1.908 & 2.07 & 7.18 & 264.70 & 0.15 & Clear & High \\
\hline LP-MW-14-10 D & $04 / 11 / 2016$ & 1230 & 4.55 & 10.38 & 0.514 & 3.75 & 7.95 & 199.10 & 0.06 & Clear & High \\
\hline LP-MW-17-10 S & 03/11/2016 & 1655 & 3.91 & 14.75 & 5.501 & 8.83 & 7.24 & -74.50 & 0.00 & Iron & High \\
\hline LP-MW-17-10 M14 & --- & --- & --- & --- & --- & --- & --- & --- & --- & --- & --- \\
\hline LP-MW-17-10 M26 & --- & --- & --- & --- & --- & --- & --- & --- & --- & --- & --- \\
\hline LP-MW-17-10 D & 03/11/2016 & 1635 & 4.30 & 10.49 & 0.421 & 2.47 & 8.16 & -106.80 & 0.10 & Clear & High \\
\hline LP-MW-18-10 S & $04 / 11 / 2016$ & 1040 & 4.06 & 13.94 & 1.218 & 11.21 & 7.57 & 227.60 & 0.00 & Clear & High \\
\hline
\end{tabular}




\begin{tabular}{|c|c|c|c|c|c|c|c|c|c|c|c|}
\hline LP-MW-18-10 M & 04/11/2016 & 1105 & 3.98 & 11.16 & 1.952 & 2.05 & 7.40 & 258.30 & 1.08 & Clear & High \\
\hline LP-MW-19-10 S & 04/11/2016 & 1150 & 2.21 & 11.76 & 1.023 & 1.11 & 7.19 & 221.00 & 0.15 & Clear & High \\
\hline LP-MW-22-10 S & $02 / 11 / 2016$ & 1100 & 2.50 & 13.34 & 2.598 & 2.45 & 7.00 & -30.40 & --- & Yellowish & High \\
\hline LP-MW-22-10 M & --- & --- & --- & --- & --- & --- & --- & --- & --- & --- & --- \\
\hline
\end{tabular}

\begin{tabular}{|c|c|c|c|c|c|c|c|c|c|c|c|}
\hline \multirow[b]{2}{*}{ Well Label } & \multicolumn{11}{|c|}{ November 2016 Field Data for Lanark County } \\
\hline & Date & Time & $\begin{array}{l}\text { Depth to } \\
\text { Water } \\
\text { (m) }\end{array}$ & $\begin{array}{c}\text { Temperature } \\
\left({ }^{\circ} \mathrm{C}\right)\end{array}$ & $\begin{array}{c}\text { Conductivity } \\
\left(\mathrm{mS} / \mathrm{cm}^{2}\right)\end{array}$ & $\begin{array}{c}\mathrm{DO} \\
(\mathrm{mg} / \mathrm{L})\end{array}$ & $\mathrm{pH}$ & ORP & $\begin{array}{l}\text { Nitrate } \\
\text { (mg/L) }\end{array}$ & $\begin{array}{l}\text { Water } \\
\text { Quality }\end{array}$ & $\begin{array}{c}\text { Water } \\
\text { Quantity }\end{array}$ \\
\hline TW1 S & $07 / 11 / 2016$ & --- & Dry & --- & --- & $\begin{array}{c}-- \\
\end{array}$ & --- & --- & --- & --- & --- \\
\hline TW1 M & $07 / 11 / 2016$ & 1220 & 7.16 & 9.81 & 0.832 & 7.19 & 7.31 & 72.70 & 1.37 & Clear & High \\
\hline TW1 D & $07 / 11 / 2016$ & 1250 & 6.97 & 9.27 & 0.992 & 3.60 & 7.28 & 44.00 & 1.23 & Clear & High \\
\hline TW3 S & 08/11/2016 & --- & 6.40 & --- & --- & --- & --- & --- & --- & --- & --- \\
\hline TW3D & 08/11/2016 & --- & 6.29 & --- & --- & --- & --- & --- & --- & --- & --- \\
\hline TW4 S & 07/11/2016 & --- & 6.40 & --- & --- & --- & --- & --- & --- & --- & --- \\
\hline TW4D & $07 / 11 / 2016$ & --- & 6.29 & --- & --- & --- & --- & --- & --- & --- & --- \\
\hline TW5 S & 07/11/2016 & 1410 & 4.90 & 9.39 & 0.700 & 5.68 & 7.21 & 110.60 & 1.06 & Clear & High \\
\hline TW6 S & $07 / 11 / 2016$ & 1445 & 4.38 & 10.39 & 0.750 & 8.65 & 7.14 & 121.50 & 0.92 & Clear & Very high \\
\hline TW7 S & 07/11/2016 & 1035 & 6.10 & 11.15 & 0.961 & 2.60 & 6.77 & 166.70 & 0.77 & Clear & High \\
\hline TW7M & $07 / 11 / 2016$ & 1105 & 6.10 & 8.96 & 1.053 & 6.13 & 7.21 & 119.60 & 0.52 & Clear & High \\
\hline TW7 D & 07/11/2016 & 1135 & 6.10 & 8.93 & 1.049 & 5.65 & 7.10 & 94.60 & 1.42 & Clear & High \\
\hline TW8 (open) & $07 / 11 / 2016$ & 1520 & 5.93 & 9.36 & 0.865 & 5.13 & 7.03 & 59.20 & 0.47 & Clear & High \\
\hline TW9 S & 07/11/2016 & 1000 & 2.83 & 11.48 & 1.096 & 3.20 & 7.12 & 135.00 & 0.20 & Iron & High \\
\hline TW11 S & 08/11/2016 & --- & 3.14 & --- & --- & --- & --- & --- & --- & --- & --- \\
\hline TW11 M & 08/11/2016 & 0930 & 3.20 & 11.26 & 1.435 & 2.72 & 7.19 & 121.20 & 0.23 & Clear & Extremely low \\
\hline TW11D & 08/11/2016 & 0955 & 3.20 & 12.24 & 1.406 & 1.53 & 7.17 & 135.80 & 0.18 & Clear & Extremely low \\
\hline TW16 S & 08/11/2016 & 1130 & 1.58 & 12.85 & 1.425 & 2.16 & 7.40 & 82.60 & 0.12 & Iron & Low \\
\hline TW16 M & 08/11/2016 & 1155 & 1.58 & 11.19 & 1.463 & 2.25 & 7.39 & 65.80 & 0.12 & Clear & High \\
\hline TW17 (open) & 08/11/2016 & 1045 & 3.07 & 11.31 & 1.240 & 3.09 & 7.19 & 29.20 & 1.78 & Clear & High \\
\hline TW18 S & 08/11/2016 & 1245 & 3.16 & 12.14 & 0.978 & 2.00 & 6.93 & 19.80 & 0.18 & Clear & High \\
\hline
\end{tabular}




\begin{tabular}{|c|cc|cccccccccc} 
TW19 S & $07 / 11 / 2016$ & 0820 & 2.57 & 11.86 & 1.187 & 4.32 & 6.85 & 115.40 & 0.00 & Iron & High & Moder \\
TW19 M & $07 / 11 / 2016$ & 0855 & 2.41 & 8.67 & 0.982 & 2.85 & 7.55 & 88.90 & 0.13 & Clear & Moderate \\
TW19 D & $07 / 11 / 2016$ & 0915 & 2.41 & 8.79 & 1.015 & 3.05 & 7.53 & 52.90 & 0.13 & Clear & Moderate \\
TW20 (open) & $07 / 11 / 2016$ & 1615 & 6.14 & 10.42 & 0.466 & 2.42 & 6.89 & 78.50 & 0.30 & Clear & Low \\
\hline
\end{tabular}

\begin{tabular}{|c|c|c|c|c|c|c|c|c|c|c|c|}
\hline \multirow[b]{2}{*}{ Well Label } & \multicolumn{11}{|c|}{ November 2016 Sample Analysis for Norfolk County ( $\mu \mathrm{g} / \mathrm{L})$} \\
\hline & Acetamiprid & Atrazine & Azoxystrobin & Clothianidin & Cyantraniliprole & Dinotefuran & Imidacloprid & Mefenoxam & Metolachlor & Thiacloprid & Thiamethoxam \\
\hline LP-MW-02-10 M & 0.0000 & 0.0002 & 0.0000 & 0.0000 & 0.0000 & 0.0015 & 0.0172 & 0.0069 & 0.0000 & 0.00 & 0.0000 \\
\hline LP-MW-02-10 D & 0.0000 & 0.0000 & 0.0000 & 0.0000 & 0.0000 & 0.0000 & 0.0259 & 0.0014 & 0.0000 & 0.00 & 0.0000 \\
\hline LP-MW-03-10 S & 0.0000 & 0.0000 & 0.0000 & 0.0000 & 0.0000 & 0.0000 & 0.0000 & 0.0002 & 0.0144 & 0.00 & 0.0008 \\
\hline LP-MW-03-10 D & 0.0000 & 0.0018 & 0.0000 & 0.0000 & 0.0000 & 0.0000 & 0.0221 & 0.0000 & 0.0078 & 0.00 & 0.0091 \\
\hline LP-MW-04-10 S & 0.0000 & 0.0000 & 0.0000 & 0.0000 & 0.0000 & 0.0000 & 0.0225 & 0.0105 & 0.0021 & 0.00 & 0.0041 \\
\hline LP-MW-04-10 M & 0.0000 & 0.0000 & 0.0000 & 0.0057 & 0.0000 & 0.0000 & 0.0006 & 0.0000 & 0.0119 & 0.00 & 0.0009 \\
\hline LP-MW-04-10 D & 0.0000 & 0.0000 & 0.0000 & 0.0017 & 0.0000 & 0.0000 & 0.0180 & 0.0000 & 0.0367 & 0.00 & 0.0136 \\
\hline LP-MW-05-10 D & --- & --- & --- & --- & --- & --- & --- & --- & --- & --- & --- \\
\hline LP-MW-07-10 S & 0.0000 & 0.0021 & 0.0000 & 0.0080 & 0.0000 & 0.0000 & 0.0013 & 0.0000 & 0.0167 & 0.00 & 0.0015 \\
\hline LP-MW-07-10 D & 0.0000 & 0.0000 & 0.0000 & 0.0000 & 0.0000 & 0.0000 & 0.0202 & 0.0000 & 0.0132 & 0.00 & 0.0105 \\
\hline LP-MW-08-10 S & 0.0000 & 0.0000 & 0.0000 & 0.0000 & 0.0000 & 0.0000 & 0.0088 & 0.0103 & 0.0000 & 0.00 & 0.0006 \\
\hline LP-MW-08-10 M & 0.0000 & 0.0000 & 0.0000 & 0.0000 & 0.0000 & 0.0000 & 0.0037 & 0.0011 & 0.0005 & 0.00 & 0.0029 \\
\hline LP-MW-08-10 D & 0.0000 & 0.0000 & 0.0000 & 0.0052 & 0.0000 & 0.0000 & 0.0027 & 0.0000 & 0.0104 & 0.00 & 0.0021 \\
\hline LP-MW-10-10 S & 0.0000 & 0.0000 & 0.0000 & 0.0099 & 0.0000 & 0.0000 & 0.0000 & 0.0000 & 0.0383 & 0.00 & 0.0002 \\
\hline LP-MW-11-10 S & 0.0000 & 0.0000 & 0.0000 & 0.0143 & 0.0000 & 0.0025 & 0.0122 & 0.0000 & 0.0728 & 0.00 & 0.0000 \\
\hline LP-MW-11-10 D & 0.0000 & 0.0000 & 0.0000 & 0.0000 & 0.0000 & 0.0000 & 0.0088 & 0.0103 & 0.0000 & 0.00 & 0.0006 \\
\hline LP-MW-12-10 S & 0.0000 & 0.0006 & 0.0000 & 0.0000 & 0.0000 & 0.0000 & 0.0000 & 0.0000 & 0.0184 & 0.00 & 0.0162 \\
\hline LP-MW-14-10 S & 0.0000 & 0.0000 & 0.0000 & 0.0000 & 0.0000 & 0.0000 & 0.0107 & 0.0000 & 0.0000 & 0.00 & 0.0047 \\
\hline LP-MW-14-10 M & 0.0000 & 0.0000 & 0.0000 & 0.0000 & 0.0000 & 0.0000 & 0.0331 & 0.0000 & 0.0307 & 0.00 & 0.0017 \\
\hline LP-MW-14-10 D & 0.0000 & 0.0000 & 0.0000 & 0.0177 & 0.0000 & 0.0000 & 0.0152 & 0.0000 & 0.0183 & 0.00 & 0.0001 \\
\hline LP-MW-17-10 S & 0.0000 & 0.0000 & 0.0000 & 0.0000 & 0.0000 & 0.0000 & 0.0040 & 0.0000 & 0.0152 & 0.00 & 0.0000 \\
\hline LP-MW-17-10 D & 0.0000 & 0.0000 & 0.0000 & 0.0824 & 0.0000 & 0.0000 & 0.0326 & 0.0000 & 0.0041 & 0.00 & 0.0012 \\
\hline
\end{tabular}




\begin{tabular}{|c|c|c|c|c|c|c|c|c|c|c|c|}
\hline LP-MW-18-10 S & 0.0000 & 0.0000 & 0.0000 & 0.0214 & 0.0000 & 0.0000 & 0.0232 & 0.0000 & 0.0096 & 0.00 & 0.0013 \\
\hline LP-MW-18-10 M & 0.0000 & 0.0000 & 0.0000 & 0.0135 & 0.0000 & 0.0000 & 0.0097 & 0.0000 & 0.0086 & 0.00 & 0.0048 \\
\hline LP-MW-19-10 S & --- & --- & --- & --- & --- & --- & --- & --- & --- & --- & --- \\
\hline LP-MW-22-10 S & --- & --- & --- & --- & --- & --- & --- & --- & --- & --- & --- \\
\hline LP-MW-22-10 M & --- & --- & --- & --- & --- & --- & --- & --- & --- & --- & --- \\
\hline TW1 S & --- & --- & --- & --- & --- & --- & --- & -- & -- & --- & 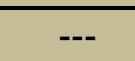 \\
\hline TW1 M & 0.0000 & 0.0004 & 0.0000 & 0.0456 & 0.0000 & 0.0000 & 0.0185 & 0.0004 & 0.0139 & 0.00 & 0.0079 \\
\hline TW1 D & 0.0000 & 0.0080 & 0.0000 & 0.0000 & 0.0000 & 0.0000 & 0.0085 & 0.0000 & 0.0101 & 0.00 & 0.0120 \\
\hline TW3 S & --- & --- & --- & --- & --- & --- & --- & --- & --- & --- & --- \\
\hline TW3D & --- & --- & --- & --- & --- & --- & --- & --- & --- & --- & --- \\
\hline TW4 S & --- & --- & --- & --- & --- & --- & --- & --- & --- & --- & --- \\
\hline TW4D & --- & --- & --- & --- & --- & --- & --- & --- & --- & --- & --- \\
\hline TW5 S & 0.0000 & 0.0000 & 0.0000 & 0.0000 & 0.0000 & 0.0000 & 0.0153 & 0.0016 & 0.0114 & 0.00 & 0.0101 \\
\hline TW6 S & 0.0000 & 0.0000 & 0.0000 & 0.0862 & 0.0000 & 0.0000 & 0.0137 & 0.0013 & 0.0610 & 0.00 & 0.0017 \\
\hline TW7 S & 0.0000 & 0.0000 & 0.0000 & 0.0138 & 0.0000 & 0.0000 & 0.0150 & 0.0027 & 0.0011 & 0.00 & 0.0058 \\
\hline TW7M & 0.0000 & 0.0000 & 0.0000 & 0.0000 & 0.0000 & 0.0000 & 0.0262 & 0.0000 & 0.0233 & 0.00 & 0.0023 \\
\hline TW7 D & 0.0000 & 0.0000 & 0.0000 & 0.0000 & 0.0000 & 0.0000 & 0.0074 & 0.0000 & 0.0000 & 0.00 & 0.0039 \\
\hline TW8 (open) & --- & --- & --- & --- & --- & --- & --- & --- & --- & --- & --- \\
\hline TW9 S & 0.0000 & 0.0000 & 0.0000 & 0.0000 & 0.0000 & 0.0000 & 0.0150 & 0.0000 & 0.0180 & 0.00 & 0.0039 \\
\hline TW11 S & --- & --- & --- & --- & --- & --- & --- & --- & --- & --- & --- \\
\hline TW11 M & 0.0000 & 0.0005 & 0.0000 & 0.0691 & 0.0000 & 0.0000 & 0.0081 & 0.0015 & 0.0099 & 0.00 & 0.0034 \\
\hline TW11D & 0.0000 & 0.0000 & 0.0000 & 0.0096 & 0.0000 & 0.0003 & 0.0210 & 0.0146 & 0.0000 & 0.00 & 0.0019 \\
\hline TW16 S & 0.0000 & 0.0000 & 0.0000 & 0.0197 & 0.0000 & 0.0004 & 0.0139 & 0.0000 & 0.0417 & 0.00 & 0.0024 \\
\hline TW16 M & 0.0000 & 0.0062 & 0.0000 & 0.0098 & 0.0000 & 0.0000 & 0.0287 & 0.0003 & 0.0065 & 0.00 & 0.0106 \\
\hline TW17 (open) & 0.0000 & 0.0015 & 0.0000 & 0.0000 & 0.0000 & 0.0000 & 0.0079 & 0.0000 & 0.0000 & 0.00 & 0.0064 \\
\hline TW18 S & 0.0000 & 0.0000 & 0.0000 & 0.0000 & 0.0000 & 0.0004 & 0.0071 & 0.0000 & 0.0025 & 0.00 & 0.0127 \\
\hline TW19 S & 0.0000 & 0.0000 & 0.0000 & 0.0097 & 0.0000 & 0.0008 & 0.0240 & 0.0000 & 0.0377 & 0.00 & 0.0012 \\
\hline TW19 M & 0.0000 & 0.0000 & 0.0000 & 0.0000 & 0.0000 & 0.0000 & 0.0080 & 0.0000 & 0.0068 & 0.00 & 0.0147 \\
\hline TW19 D & 0.0000 & 0.0000 & 0.0000 & 0.0410 & 0.0000 & 0.0000 & 0.0072 & 0.0024 & 0.0137 & 0.00 & 0.0082 \\
\hline TW20 (open) & 0.0000 & 0.0085 & 0.0000 & 0.0000 & 0.0000 & 0.0004 & 0.0119 & 0.0000 & 0.0005 & 0.00 & 0.0078 \\
\hline
\end{tabular}




\begin{tabular}{|l|llllllllllll} 
LOD $(\mu \mathrm{g} / \mathrm{L})$ & 0.0038 & 0.0027 & 0.0015 & 0.0329 & 0.0039 & 0.0070 & 0.0436 & 0.0022 & 0.0049 & 0.0033 & 0.0111 & 0.135 \\
\hline $\operatorname{LOQ}(\mu \mathrm{g} / \mathrm{L})$ & 0.0118 & 0.0076 & 0.0044 & 0.0991 & 0.0119 & 0.0182 & 0.1359 & 0.0056 & 0.0102 & 0.0096 & 0.0331 &
\end{tabular}

Neonicotinoid(s) above LOQ

Neonicotinoid(s) above LOD but below LOQ

All neonicotinoids below LOD 


\begin{tabular}{|c|c|c|c|c|c|c|c|c|c|c|c|}
\hline \multirow[b]{2}{*}{ Well Label } & \multicolumn{11}{|c|}{ April 2017 Field Data for Norfolk and Lanark County } \\
\hline & Date & Time & $\begin{array}{l}\text { Depth to } \\
\text { Water } \\
\text { (m) }\end{array}$ & $\begin{array}{c}\text { Temperature } \\
\left({ }^{\circ} \mathrm{C}\right)\end{array}$ & $\begin{array}{l}\text { Conductivity } \\
\left(\mathrm{mS} / \mathrm{cm}^{2}\right)\end{array}$ & $\begin{array}{c}\text { DO } \\
(\mathrm{mg} / \mathrm{L})\end{array}$ & $\mathrm{pH}$ & ORP & $\begin{array}{l}\text { Nitrate } \\
\text { (mg/L) }\end{array}$ & $\begin{array}{l}\text { Water } \\
\text { Quality }\end{array}$ & $\begin{array}{c}\text { Water } \\
\text { Quantity }\end{array}$ \\
\hline LP-MW-02-10 M & $07 / 04 / 2017$ & 1650 & 9.37 & 10.88 & 1.527 & 7.63 & 7.27 & 236.00 & 5.70 & Clear & High \\
\hline LP-MW-02-10 D & 07/04/2017 & 1630 & 9.46 & 10.17 & 1.450 & 7.84 & 7.38 & 20.00 & 0.00 & Clear & High \\
\hline LP-MW-03-10 S & 04/04/2017 & 1055 & 6.34 & 9.96 & 1.354 & 16.40 & 7.46 & 1.50 & 21.13 & Clear & High \\
\hline LP-MW-03-10 D & 04/04/2017 & 1115 & 6.58 & 10.54 & 1.107 & 5.57 & 7.37 & 132.10 & 0.22 & Clear & High \\
\hline LP-MW-04-10 S & --- & --- & --- & --- & --- & --- & --- & --- & --- & --- & --- \\
\hline LP-MW-04-10 M & 04/04/2017 & 1005 & 4.52 & 10.62 & 1.274 & 12.02 & 7.32 & 190.40 & 9.01 & Clear & High \\
\hline LP-MW-04-10 D & 04/04/2017 & 1020 & 4.49 & 10.30 & 1.087 & 7.46 & 7.37 & 104.20 & 0.35 & Clear & High \\
\hline LP-MW-05-10 D & 07/04/2017 & 1555 & 3.25 & 10.97 & 0.879 & 4.54 & 7.50 & 249.00 & 0.00 & Cloudy & High \\
\hline LP-MW-07-10 S & 07/04/2017 & 1500 & 5.60 & 10.96 & 1.185 & 9.06 & 7.31 & -231.00 & 1.16 & Clear & High \\
\hline LP-MW-07-10 D & 07/04/2017 & 1525 & 8.85 & 10.30 & 1.054 & 5.88 & 7.28 & 70.30 & 0.15 & Clear & High \\
\hline LP-MW-08-10 S & $07 / 04 / 2017$ & 1255 & 2.80 & 9.16 & 1.563 & 11.36 & 7.52 & 155.00 & 21.45 & Dirty & Low \\
\hline LP-MW-08-10 M & $07 / 04 / 2017$ & 1215 & 3.30 & 9.45 & 0.797 & 4.55 & 7.67 & 7.60 & 0.90 & Clear & Low \\
\hline LP-MW-08-10 D & 07/04/2017 & 1150 & 3.40 & 9.31 & 0.535 & 5.10 & 8.10 & -231.30 & 0.26 & Clear & Low \\
\hline LP-MW-10-10 S & 08/04/2017 & 1340 & 2.10 & 9.09 & 1.662 & 4.60 & 7.09 & 62.40 & 0.19 & Clear & High \\
\hline LP-MW-11-10 S & 07/04/2017 & 1030 & 4.73 & 9.32 & 0.984 & 16.68 & 7.40 & -214.50 & 0.00 & Very Dirty & Low \\
\hline LP-MW-11-10 D & $07 / 04 / 2017$ & 0950 & 4.87 & 8.68 & 0.797 & 9.60 & 7.55 & 516.80 & 0.16 & Silty & Medium \\
\hline LP-MW-12-10 S & 08/04/2017 & 1450 & 3.37 & 11.98 & 1.011 & 7.75 & 7.38 & 200.10 & 7.35 & Dirty & Low \\
\hline LP-MW-14-10 S & 07/04/2017 & 1405 & 2.82 & 9.47 & 1.543 & 3.69 & 7.35 & 229.60 & 0.67 & Clear & High \\
\hline LP-MW-14-10 M & 07/04/2017 & 1345 & 2.84 & 10.20 & 2.160 & 4.08 & 7.13 & 135.90 & 0.15 & Clear & High \\
\hline LP-MW-14-10 D & 07/04/2017 & 1325 & 3.50 & 10.06 & 0.592 & 5.40 & 7.88 & -28.20 & 0.10 & Clear & High \\
\hline LP-MW-17-10 S & --- & --- & --- & --- & --- & --- & --- & --- & --- & --- & --- \\
\hline LP-MW-17-10 M14 & --- & --- & --- & --- & --- & --- & --- & --- & --- & --- & --- \\
\hline LP-MW-17-10 M26 & --- & --- & --- & --- & --- & --- & --- & --- & --- & --- & --- \\
\hline LP-MW-17-10 D & 07/04/2017 & 1105 & 3.64 & 8.79 & 0.486 & 6.76 & 8.10 & -180.00 & 0.12 & Clear & High \\
\hline LP-MW-18-10 S & 08/04/2017 & 1250 & 2.74 & 10.01 & 1.523 & 12.65 & 7.49 & 303.70 & 1.83 & Clear & High \\
\hline
\end{tabular}




\begin{tabular}{|c|c|c|c|c|c|c|c|c|c|c|c|}
\hline LP-MW-18-10 M & $08 / 04 / 2017$ & 1225 & 2.66 & 11.75 & 2.243 & 5.02 & 7.41 & 143.00 & 1.64 & Clear & High \\
\hline LP-MW-19-10 S & 08/04/2017 & 1155 & 1.59 & 8.42 & 1.355 & 7.56 & 7.08 & 309.00 & 0.00 & Clear & High \\
\hline LP-MW-22-10 S & --- & --- & --- & --- & --- & --- & --- & --- & --- & --- & -- \\
\hline LP-MW-22-10 M & --- & --- & --- & --- & --- & --- & --- & --- & --- & --- & --- \\
\hline TW1 S & --- & --- & --- & --- & --- & --- & --- & --- & --- & --- & --- \\
\hline TW1 M & $01 / 04 / 2017$ & 1110 & 2.98 & 8.74 & 0.982 & $19.50^{*}$ & 7.18 & -378.20 & 0.75 & Clear & High \\
\hline TW1 D & $01 / 04 / 2017$ & 1130 & 3.71 & 8.73 & 1.145 & $7.81^{*}$ & 7.24 & -800.00 & 1.25 & Clear & High \\
\hline TW3 S & --- & --- & --- & --- & --- & --- & --- & --- & --- & --- & -- \\
\hline TW3D & --- & --- & --- & --- & --- & --- & --- & --- & --- & --- & --- \\
\hline TW4 S & --- & --- & --- & --- & --- & --- & -- & --- & --- & --- & --- \\
\hline TW4D & --- & --- & --- & --- & --- & --- & --- & --- & --- & --- & --- \\
\hline TW5 S & $01 / 04 / 2017$ & 1350 & 3.67 & 8.09 & 0.741 & $19.91^{*}$ & 7.27 & -346.10 & 0.66 & Clear & High \\
\hline TW6 S & $01 / 04 / 2017$ & 1415 & 3.25 & 7.60 & 0.711 & $19.86^{*}$ & 7.29 & -391.50 & 0.73 & Clear & High \\
\hline TW7 S & $01 / 04 / 2017$ & 1005 & 4.40 & 6.02 & 0.896 & 12.70 & 6.95 & -469.30 & 0.30 & Silty & High \\
\hline TW7M & $01 / 04 / 2017$ & 1020 & 4.44 & 8.40 & 1.182 & 11.71 & 7.17 & -424.00 & 0.27 & Clear & High \\
\hline TW7 D & $01 / 04 / 2017$ & 1030 & 4.50 & 8.09 & 0.918 & 12.75 & 7.14 & -366.40 & 0.55 & Clear & High \\
\hline TW8 (open) & $01 / 04 / 2017$ & 1450 & 4.31 & 7.40 & 0.885 & 14.37 & 6.99 & 760.30 & 0.51 & Clear & High \\
\hline TW9 S & $01 / 04 / 2017$ & 0930 & 1.10 & 5.43 & 1.297 & 12.50 & 7.16 & -781.00 & 0.50 & Iron & High \\
\hline TW11 S & --- & --- & --- & --- & --- & --- & --- & --- & --- & --- & --- \\
\hline TW11 M & $02 / 04 / 2017$ & 1000 & 1.45 & 9.07 & 1.671 & 5.42 & 7.05 & 130.20 & 0.40 & Clear & Low \\
\hline TW11D & 02/04/2017 & 1055 & 1.45 & 9.55 & 1.644 & 5.45 & 7.21 & -58.10 & 0.20 & Clear & Low \\
\hline TW16 S & 02/04/2017 & 1245 & 0.70 & 7.27 & 1.643 & 7.35 & 7.34 & 83.50 & 0.15 & Clear & High \\
\hline TW16 M & 02/04/2017 & 1300 & 0.70 & 7.27 & 1.643 & 7.35 & 7.34 & 83.50 & 0.15 & Clear & High \\
\hline TW17 (open) & 02/04/2017 & 1210 & 1.70 & 4.60 & 1.446 & 8.04 & 6.63 & 173.90 & 6.04 & Iron & High \\
\hline TW18 S & 02/04/2017 & 1400 & 1.20 & 6.10 & 1.001 & 6.45 & 7.00 & 84.50 & 2.04 & Clear & High \\
\hline TW19 S & $01 / 04 / 2017$ & 0815 & 1.97 & 3.87 & 1.131 & 13.65 & 7.12 & -165.00 & 0.31 & Sandy & High \\
\hline TW19 M & $01 / 04 / 2017$ & 0840 & 1.14 & 8.18 & 1.146 & 9.77 & 7.51 & 7.10 & 0.17 & Clear & Moderate \\
\hline TW19 D & $01 / 04 / 2017$ & 0855 & 1.14 & 8.04 & 1.193 & 8.68 & 7.46 & 61.20 & 0.22 & Clear & Moderate \\
\hline TW20 (open) & $01 / 04 / 2017$ & 1530 & 2.25 & 6.28 & 0.203 & 14.57 & 6.89 & -298.00 & 0.56 & Clear & High \\
\hline
\end{tabular}




\begin{tabular}{|c|c|c|c|c|c|c|c|c|c|c|c|}
\hline & & & April 201 & 17 Sampl & le Analysis & for Norfo & olk and La & nark Col & unty ( $\mu g / L$ & L) & \\
\hline Well Label & Acetamiprid & Atrazine & Azoxystrobin & Clothianidin & Cyantraniliprole & Dinotefuran & Imidacloprid I & Mefenoxam & Metolachlor T & Thiacloprid & Thiamethoxam \\
\hline LP-MW-02-10 M & 0.0000 & 0.0000 & 0.0000 & 0.0000 & 0.0000 & 0.0000 & 0.0000 & 0.0000 & 0.0000 & 0.0000 & 0.0000 \\
\hline LP-MW-02-10 D & 0.0000 & 0.0000 & 0.0000 & 0.0000 & 0.0000 & 0.0000 & 0.0000 & 0.0000 & 0.0000 & 0.0000 & 0.0000 \\
\hline LP-MW-03-10 S & 0.0000 & 0.0000 & 0.0000 & 0.0000 & 0.0000 & 0.0000 & 0.0000 & 0.0000 & 0.0000 & 0.0000 & 0.0005 \\
\hline LP-MW-03-10 D & 0.0000 & 0.0000 & 0.0000 & 0.0000 & 0.0000 & 0.0000 & 0.0000 & 0.0000 & 0.0000 & 0.0000 & 0.0000 \\
\hline LP-MW-04-10 S & --- & --- & --- & --- & --- & --- & --- & --- & --- & --- & --- \\
\hline LP-MW-04-10 M & 0.0000 & 0.0000 & 0.0000 & 0.0000 & 0.0000 & 0.0000 & 0.0000 & 0.0000 & 0.0000 & 0.0000 & 0.0012 \\
\hline LP-MW-04-10 D & 0.0000 & 0.0000 & 0.0000 & 0.0000 & 0.0000 & 0.0000 & 0.0000 & 0.0000 & 0.0000 & 0.0000 & 0.0000 \\
\hline LP-MW-05-10 D & 0.0000 & 0.0000 & 0.0000 & 0.0000 & 0.0000 & 0.0000 & 0.0000 & 0.0000 & 0.0000 & 0.0000 & 0.0000 \\
\hline LP-MW-07-10 S & 0.0000 & 0.0019 & 0.0000 & 0.0000 & 0.0000 & 0.0000 & 0.0000 & 0.0000 & 0.0205 & 0.0000 & 0.0000 \\
\hline LP-MW-07-10 D & 0.0000 & 0.0000 & 0.0000 & 0.0000 & 0.0000 & 0.0000 & 0.0000 & 0.0000 & 0.0000 & 0.0000 & 0.0000 \\
\hline LP-MW-08-10 S & 0.0000 & 0.0001 & 0.0000 & 0.0000 & 0.0000 & 0.0000 & 0.0000 & 0.0209 & 0.0049 & 0.0209 & 0.0000 \\
\hline LP-MW-08-10 M & 0.0000 & 0.0000 & 0.0000 & 0.0000 & 0.0000 & 0.0000 & 0.0000 & 0.0000 & 0.0000 & 0.0000 & 0.0000 \\
\hline LP-MW-08-10 D & 0.0000 & 0.0000 & 0.0000 & 0.0000 & 0.0000 & 0.0000 & 0.0000 & 0.0000 & 0.0000 & 0.0000 & 0.0000 \\
\hline LP-MW-10-10 S & 0.0000 & 0.0000 & 0.0000 & 0.0000 & 0.0000 & 0.0000 & 0.0000 & 0.0000 & 0.0184 & 0.0000 & 0.0000 \\
\hline LP-MW-11-10 S & 0.0000 & 0.0000 & 0.0000 & 0.0000 & 0.0000 & 0.0000 & 0.0000 & 0.0000 & 0.0000 & 0.0000 & 0.0000 \\
\hline LP-MW-11-10 D & 0.0000 & 0.0000 & 0.0000 & 0.0000 & 0.0000 & 0.0000 & 0.0000 & 0.0000 & 0.0000 & 0.0000 & 0.0000 \\
\hline LP-MW-12-10 S & 0.0000 & 0.0000 & 0.0000 & 0.0000 & 0.0000 & 0.0000 & 0.0000 & 0.0000 & 0.0043 & 0.0000 & 0.0000 \\
\hline LP-MW-14-10 S & 0.0000 & 0.0000 & 0.0000 & 0.0000 & 0.0000 & 0.0000 & 0.0000 & 0.0000 & 0.0045 & 0.0000 & 0.0000 \\
\hline LP-MW-14-10 M & 0.0000 & 0.0000 & 0.0000 & 0.0000 & 0.0000 & 0.0000 & 0.0000 & 0.0000 & 0.0407 & 0.0000 & 0.0000 \\
\hline LP-MW-14-10 D & 0.0000 & 0.0000 & 0.0000 & 0.0000 & 0.0000 & 0.0000 & 0.0000 & 0.0004 & 0.0000 & 0.0004 & 0.0026 \\
\hline LP-MW-17-10 S & --- & --- & --- & --- & --- & --- & --- & --- & --- & --- & --- \\
\hline LP-MW-17-10 M14 & --- & --- & --- & --- & --- & --- & --- & --- & --- & --- & --- \\
\hline LP-MW-17-10 M26 & --- & --- & --- & --- & --- & --- & --- & --- & --- & --- & --- \\
\hline LP-MW-17-10 D & 0.0000 & 0.0000 & 0.0000 & 0.0000 & 0.0000 & 0.0000 & 0.0000 & 0.0000 & 0.0000 & 0.0000 & 0.0009 \\
\hline LP-MW-18-10 S & 0.0000 & 0.0000 & 0.0000 & 0.0000 & 0.0000 & 0.0000 & 0.0000 & 0.0000 & 0.0005 & 0.0000 & 0.0000 \\
\hline LP-MW-18-10 M & 0.0000 & 0.0000 & 0.0000 & 0.0000 & 0.0338 & 0.0000 & 0.0000 & 0.0000 & 0.0035 & 0.0000 & 0.0000 \\
\hline LP-MW-19-10 S & 0.0000 & 0.0000 & 0.0000 & 0.0000 & 0.0000 & 0.0000 & 0.0000 & 0.0000 & 0.0012 & 0.0000 & 0.0000 \\
\hline
\end{tabular}




\begin{tabular}{|c|c|c|c|c|c|c|c|c|c|c|c|}
\hline LP-MW-22-10 S & --- & --- & --- & --- & --- & --- & --- & --- & --- & --- & --- \\
\hline LP-MW-22-10 M & --- & --- & --- & --- & --- & --- & --- & --- & --- & --- & --- \\
\hline TW1S & $\overline{---}$ & --- & --- & --- & --- & --- & --- & $\overline{c--}$ & --- & --- & --- \\
\hline TW1 M & 0.0000 & 0.0174 & 0.0000 & 0.0000 & 0.0000 & 0.0000 & 0.0000 & 0.0000 & 0.0000 & 0.0000 & 0.0000 \\
\hline TW1 D & 0.0000 & 0.0599 & 0.0000 & 0.0000 & 0.0000 & 0.0000 & 0.0000 & 0.0000 & 0.0000 & 0.0000 & 0.0000 \\
\hline TW3 S & --- & --- & --- & --- & --- & --- & --- & --- & --- & --- & --- \\
\hline TW3D & --- & --- & --- & --- & --- & --- & --- & --- & --- & --- & --- \\
\hline TW4 S & --- & --- & --- & --- & --- & --- & --- & --- & --- & --- & --- \\
\hline TW4D & --- & --- & --- & --- & --- & --- & --- & --- & --- & --- & --- \\
\hline TW5 S & 0.0000 & 0.0013 & 0.0000 & 0.0106 & 0.0007 & 0.0000 & 0.0000 & 0.0000 & 0.0000 & 0.0000 & 0.0000 \\
\hline TW6 S & 0.0000 & 0.0000 & 0.0000 & 0.0000 & 0.0000 & 0.0000 & 0.0000 & 0.0000 & 0.0000 & 0.0000 & 0.0000 \\
\hline TW7 S & 0.0000 & 0.0000 & 0.0000 & 0.0000 & 0.0000 & 0.0000 & 0.0000 & 0.0000 & 0.0000 & 0.0000 & 0.0035 \\
\hline TW7M & 0.0000 & 0.0033 & 0.0000 & 0.0000 & 0.0000 & 0.0000 & 0.0000 & 0.0000 & 0.0000 & 0.0000 & 0.0000 \\
\hline TW7 D & 0.0000 & 0.0000 & 0.0000 & 0.0000 & 0.0000 & 0.0000 & 0.0000 & 0.0000 & 0.0000 & 0.0000 & 0.0000 \\
\hline TW8 (open) & 0.0000 & 0.0002 & 0.0000 & 0.0000 & 0.0000 & 0.0000 & 0.0000 & 0.0000 & 0.0016 & 0.0000 & 0.0019 \\
\hline TW9 S & 0.0000 & 0.0000 & 0.0000 & 0.0000 & 0.0000 & 0.0000 & 0.0000 & 0.0000 & 0.0000 & 0.0000 & 0.0000 \\
\hline TW11 S & --- & --- & --- & --- & --- & --- & --- & --- & --- & --- & --- \\
\hline TW11 M & 0.0000 & 0.0000 & 0.0000 & 0.0000 & 0.0000 & 0.0000 & 0.0000 & 0.0000 & 0.0000 & 0.0000 & 0.0000 \\
\hline TW11D & 0.0000 & 0.0000 & 0.0000 & 0.0000 & 0.0000 & 0.0000 & 0.0000 & 0.0000 & 0.0036 & 0.0000 & 0.0000 \\
\hline TW16 S & 0.0000 & 0.0000 & 0.0000 & 0.0000 & 0.0000 & 0.0000 & 0.0000 & 0.0000 & 0.0000 & 0.0000 & 0.0000 \\
\hline TW16 M & 0.0000 & 0.0000 & 0.0000 & 0.0000 & 0.0000 & 0.0000 & 0.0000 & 0.0000 & 0.0000 & 0.0000 & 0.0000 \\
\hline TW17 (open) & 0.0000 & 0.0878 & 0.0000 & 0.0000 & 0.0000 & 0.0000 & 0.0000 & 0.0000 & 0.0021 & 0.0000 & 0.4235 \\
\hline TW18 S & 0.0000 & 0.0000 & 0.0000 & 0.0000 & 0.0000 & 0.0000 & 0.0000 & 0.0000 & 0.0000 & 0.0000 & 0.0001 \\
\hline TW19 S & 0.0000 & 0.0000 & 0.0000 & 0.0000 & 0.0000 & 0.0000 & 0.0000 & 0.0000 & 0.0000 & 0.0000 & 0.0000 \\
\hline TW19 M & 0.0000 & 0.0000 & 0.0000 & 0.0000 & 0.0000 & 0.0000 & 0.0000 & 0.0000 & 0.0000 & 0.0000 & 0.0011 \\
\hline TW19 D & 0.0000 & 0.0000 & 0.0000 & 0.0000 & 0.0000 & 0.0000 & 0.0000 & 0.0000 & 0.0091 & 0.0000 & 0.0000 \\
\hline TW20 (open) & 0.0000 & 0.0000 & 0.0000 & 0.0088 & 0.0000 & 0.0000 & 0.0000 & 0.0000 & 0.0000 & 0.0000 & 0.0009 \\
\hline LOD $(\mu \mathrm{g} / \mathrm{L})$ & 0.003 & 0.002 & 0.001 & 0.012 & 0.003 & 0.011 & 0.020 & 0.002 & 0.013 & 0.046 & 0.022 \\
\hline $\mathrm{LOQ}(\mu \mathrm{g} / \mathrm{L})$ & 0.009 & 0.006 & 0.004 & 0.036 & 0.008 & 0.032 & 0.061 & 0.006 & 0.028 & 0.122 & 0.068 \\
\hline
\end{tabular}


Neonicotinoid(s) above LOQ

Neonicotinoid(s) above LOD but below LOQ

All neonicotinoids below LOD

\begin{tabular}{|c|c|c|c|c|c|c|c|c|c|c|c|}
\hline \multicolumn{12}{|c|}{ July 2016 Soil Sample Analysis ( $\mu \mathrm{g} / \mathrm{L})$} \\
\hline Well Label & Acetamiprid & Atrazine & Azoxystrobin & Clothianidin & Cyantraniliprole & Dinotefuran & Imidacloprid & Mefenoxam & Metolachlor & Thiacloprid & Thiamethoxam \\
\hline LP-MW-02-10 & 0.00 & 1.20 & 0.00 & 0.75 & 0.00 & 0.00 & 0.00 & 0.00 & 0.30 & 0.00 & 0.00 \\
\hline LP-MW-04-10 & 0.00 & 0.27 & 0.36 & 1.52 & 0.00 & 0.00 & 0.13 & 0.00 & 0.00 & 0.00 & 0.07 \\
\hline LP-MW-05-10 & 0.00 & 0.17 & 0.00 & 0.00 & 0.00 & 0.00 & 0.21 & 0.00 & 0.00 & 0.00 & 0.00 \\
\hline LP-MW-08-10 & 0.00 & 0.31 & 0.15 & 0.63 & 0.00 & 0.00 & 0.01 & 0.00 & 0.00 & 0.00 & 0.00 \\
\hline LP-MW-10-10 & 0.00 & 13.15 & 0.00 & 0.40 & 0.00 & 0.00 & 0.00 & 0.00 & 0.00 & 0.00 & 0.00 \\
\hline LP-MW-11-10 & 0.00 & 0.03 & 0.00 & 0.00 & 0.00 & 0.00 & 0.00 & 0.00 & 0.00 & 0.00 & 0.00 \\
\hline LP-MW-12-10 & 0.00 & 0.16 & 0.00 & 0.07 & 0.00 & 0.00 & 0.00 & 0.00 & 0.26 & 0.00 & 0.00 \\
\hline LP-MW-14-10 & 0.00 & 0.09 & 0.08 & 0.26 & 0.00 & 0.00 & 0.10 & 0.00 & 0.03 & 0.00 & 0.00 \\
\hline LP-MW-18-10 & 0.00 & 0.24 & 0.67 & 4.30 & 0.00 & 0.00 & 0.82 & 0.00 & 1.45 & 0.00 & 0.21 \\
\hline LP-MW-19-10 & 0.00 & 0.04 & 0.07 & 0.04 & 0.00 & 0.00 & 0.29 & 0.00 & 0.02 & 0.00 & 0.00 \\
\hline LP-MW-22-10 & 0.00 & 0.12 & 0.16 & 0.21 & 0.00 & 0.00 & 5.00 & 0.00 & 0.00 & 0.00 & 0.00 \\
\hline Hay Field & 0.00 & 0.26 & 0.00 & 0.76 & 0.00 & 0.00 & 0.04 & 0.00 & 0.64 & 0.00 & 0.00 \\
\hline TW9 & 0.00 & 0.12 & 0.00 & 0.00 & 0.00 & 0.00 & 0.00 & 0.00 & 0.00 & 0.00 & 0.00 \\
\hline TW11 & 0.00 & 0.10 & 0.00 & 0.00 & 0.00 & 0.00 & 0.00 & 0.00 & 0.00 & 0.00 & 0.00 \\
\hline TW13 & 0.00 & 0.01 & 0.00 & 0.00 & 0.00 & 0.00 & 0.00 & 0.00 & 0.00 & 0.00 & 0.00 \\
\hline TW17 & 0.00 & 0.12 & 0.00 & 6.33 & 0.00 & 0.00 & 0.00 & 0.00 & 0.08 & 0.00 & 1.01 \\
\hline TW18 & 0.00 & 0.08 & 0.00 & 0.00 & 0.00 & 0.00 & 0.00 & 0.00 & 0.00 & 0.00 & 0.00 \\
\hline LOD (ng/g) & 0.01 & 0.02 & 0.01 & 0.32 & 0.01 & 0.04 & 0.14 & 0.01 & 0.05 & 0.00 & 0.03 \\
\hline LOQ (ng/g) & 0.04 & 0.06 & 0.02 & 0.81 & 0.04 & 0.11 & 0.43 & 0.04 & 0.13 & 0.01 & 0.08 \\
\hline
\end{tabular}

Neonicotinoid(s) above LOQ

Neonicotinoid(s) above LOD but below LOQ

All neonicotinoids below LOD 
Appendix C - Pressure Transducer Data 


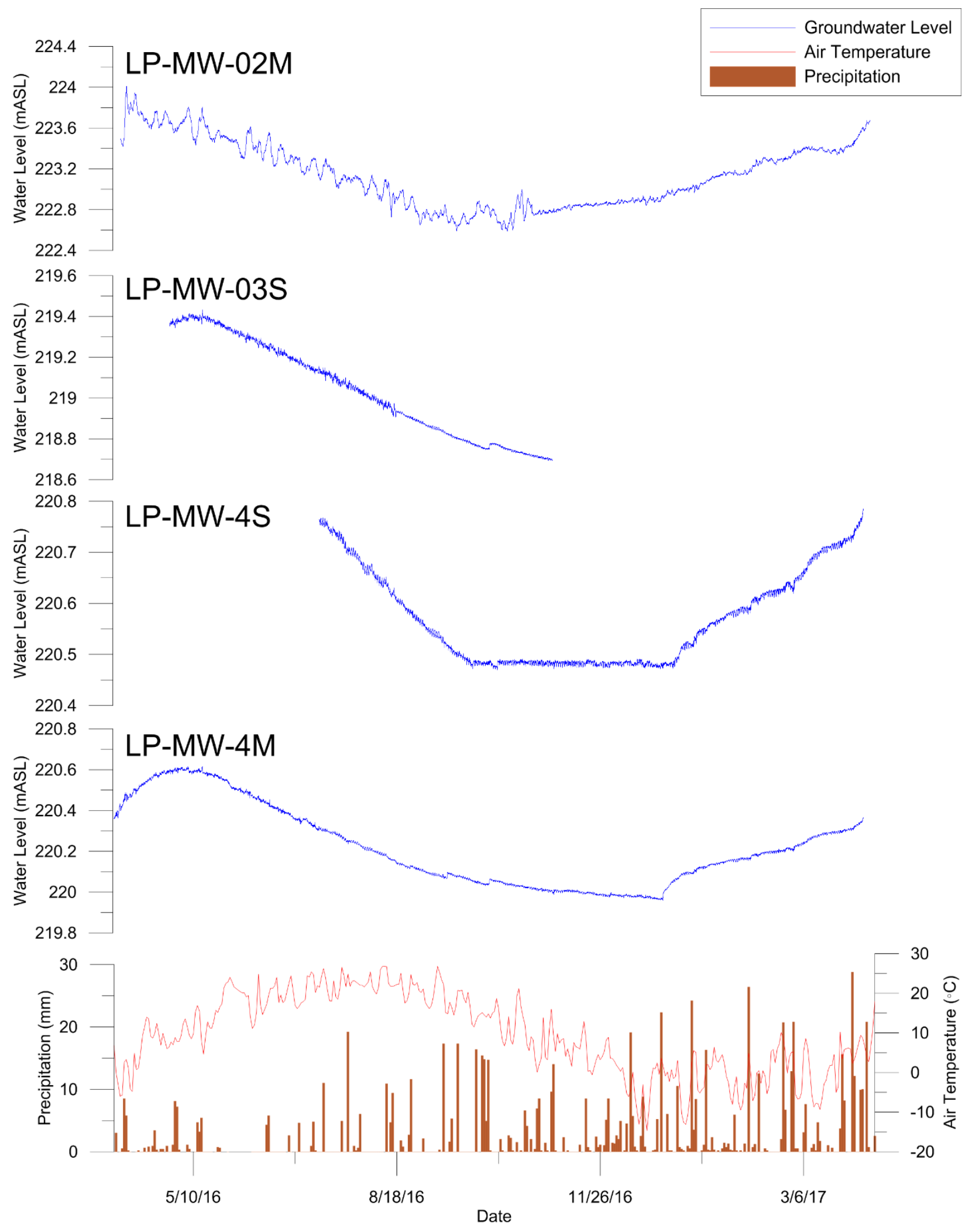









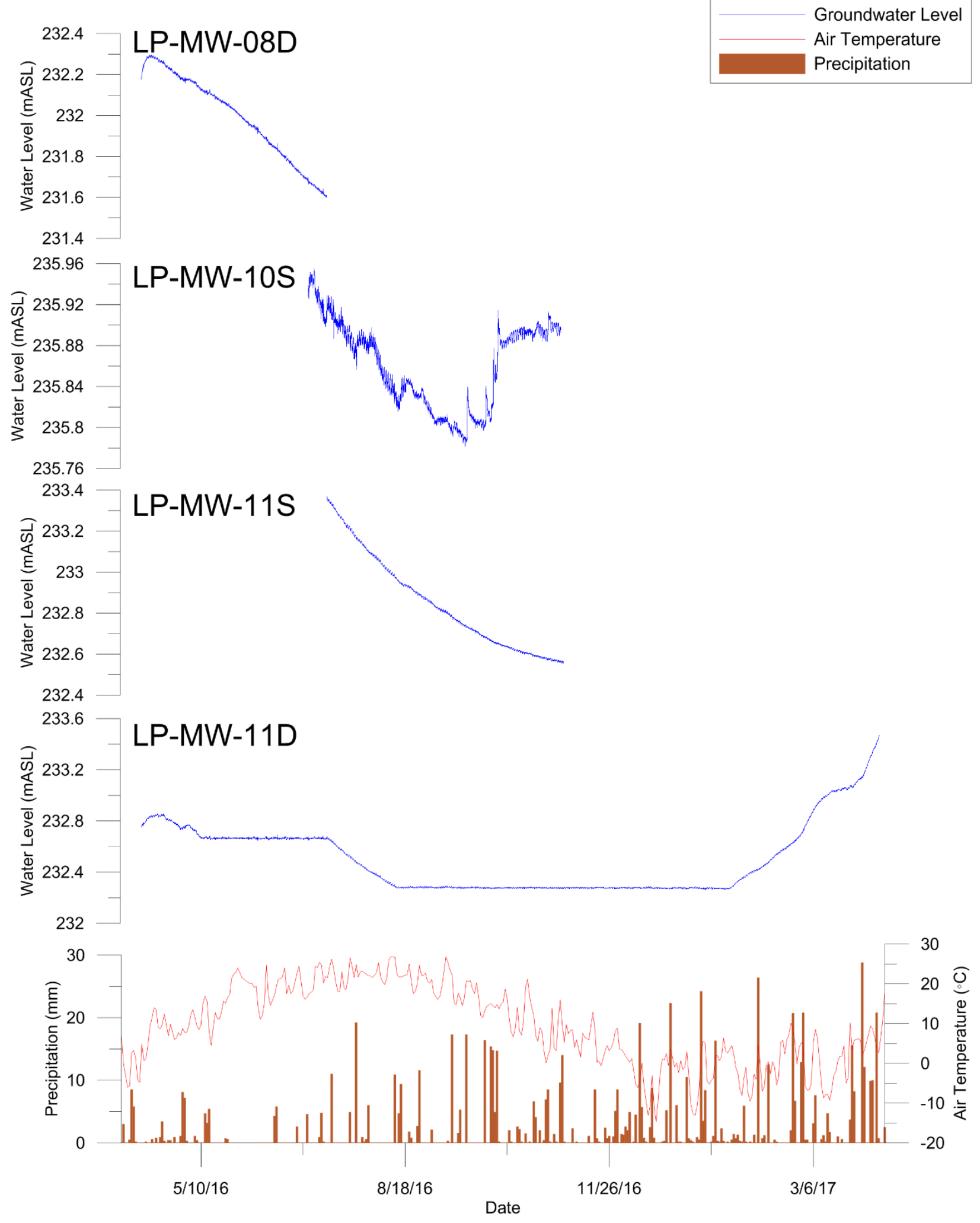




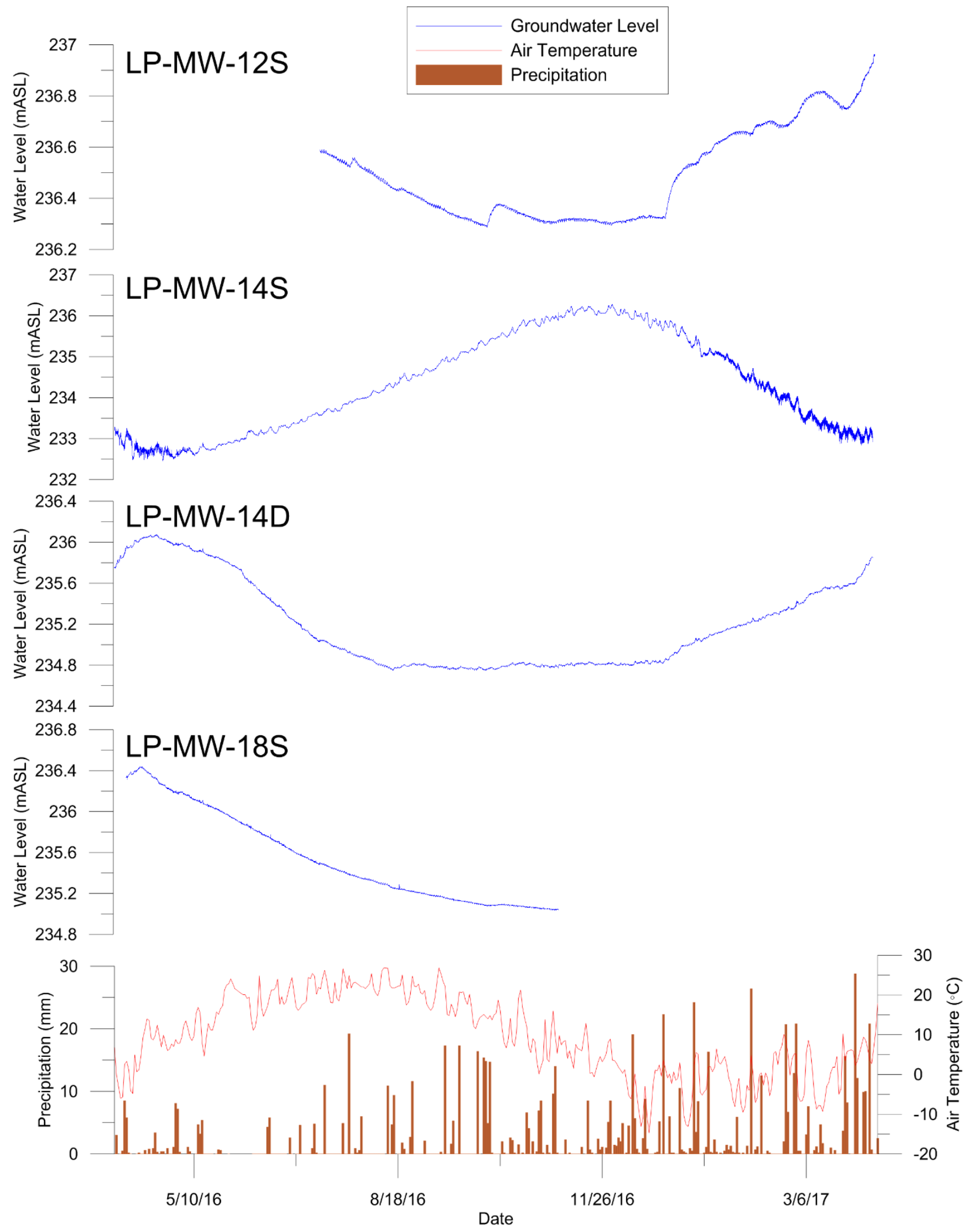



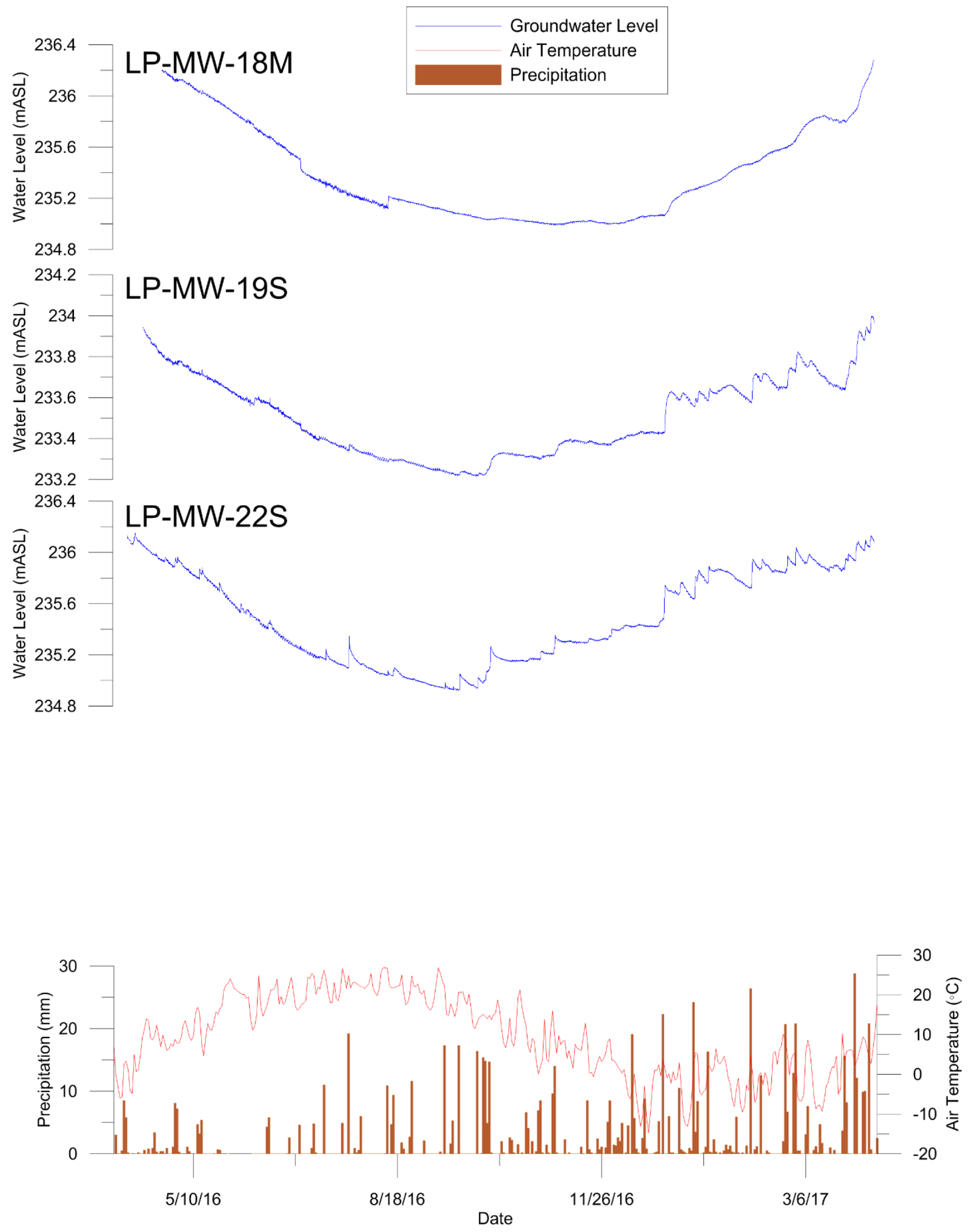


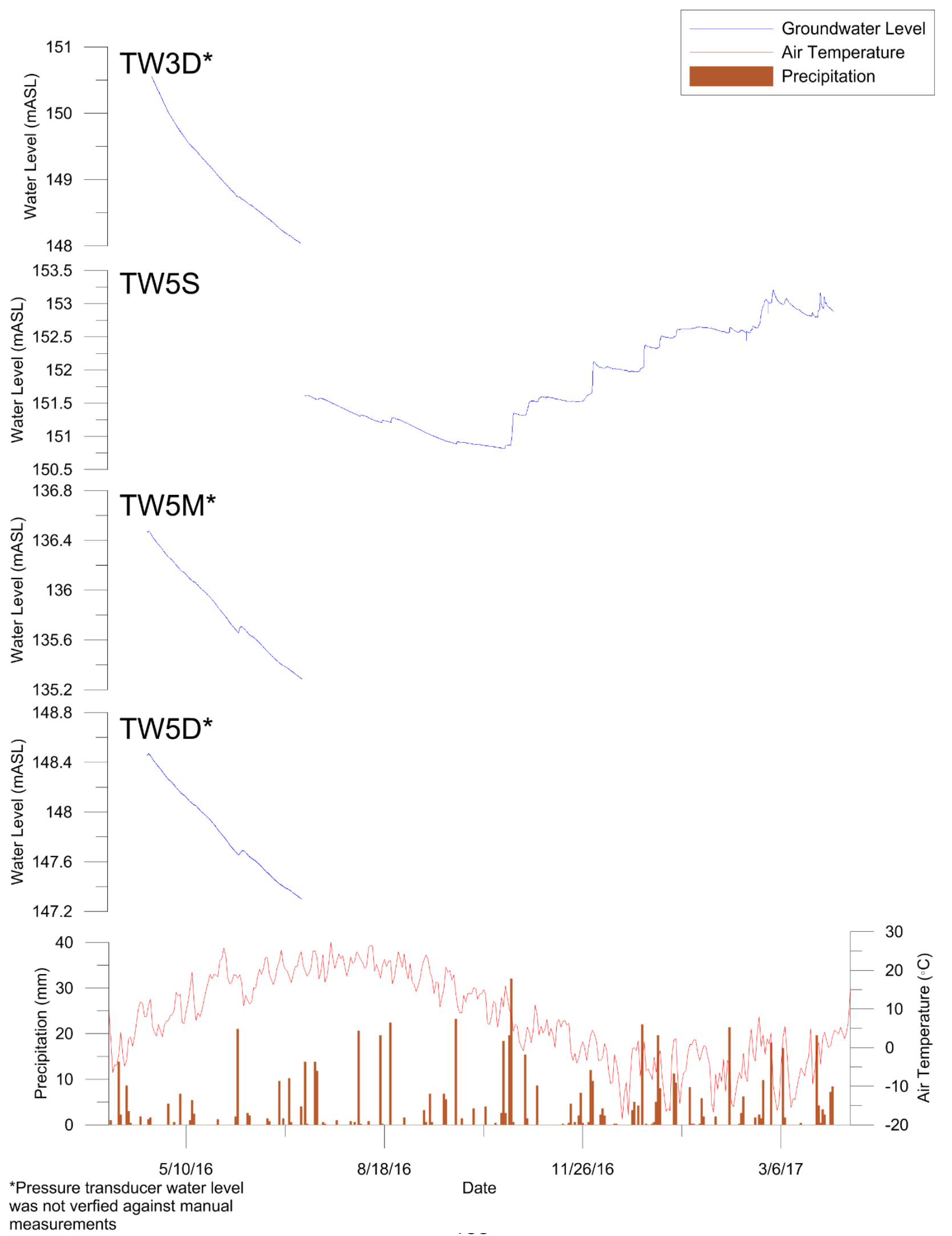




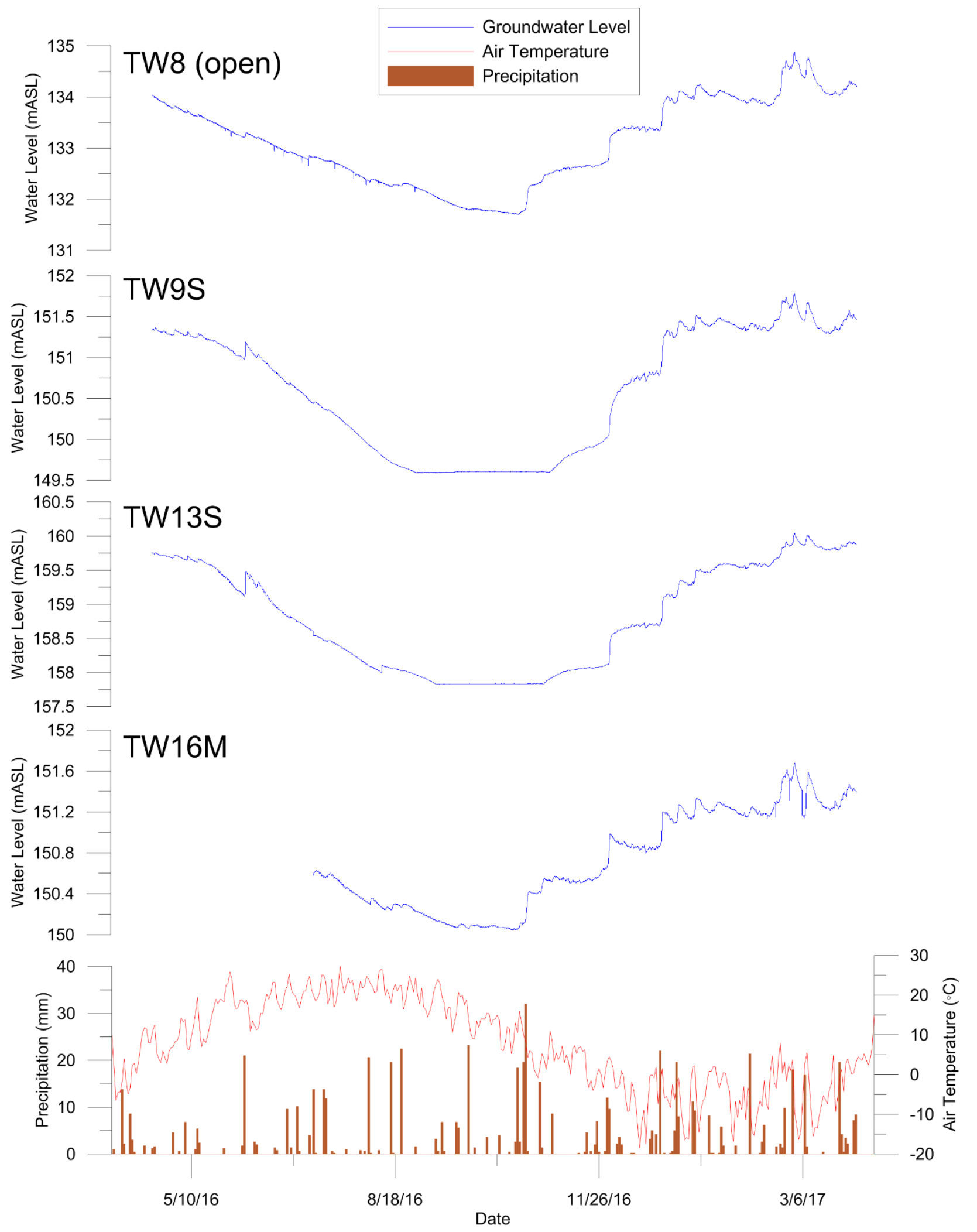




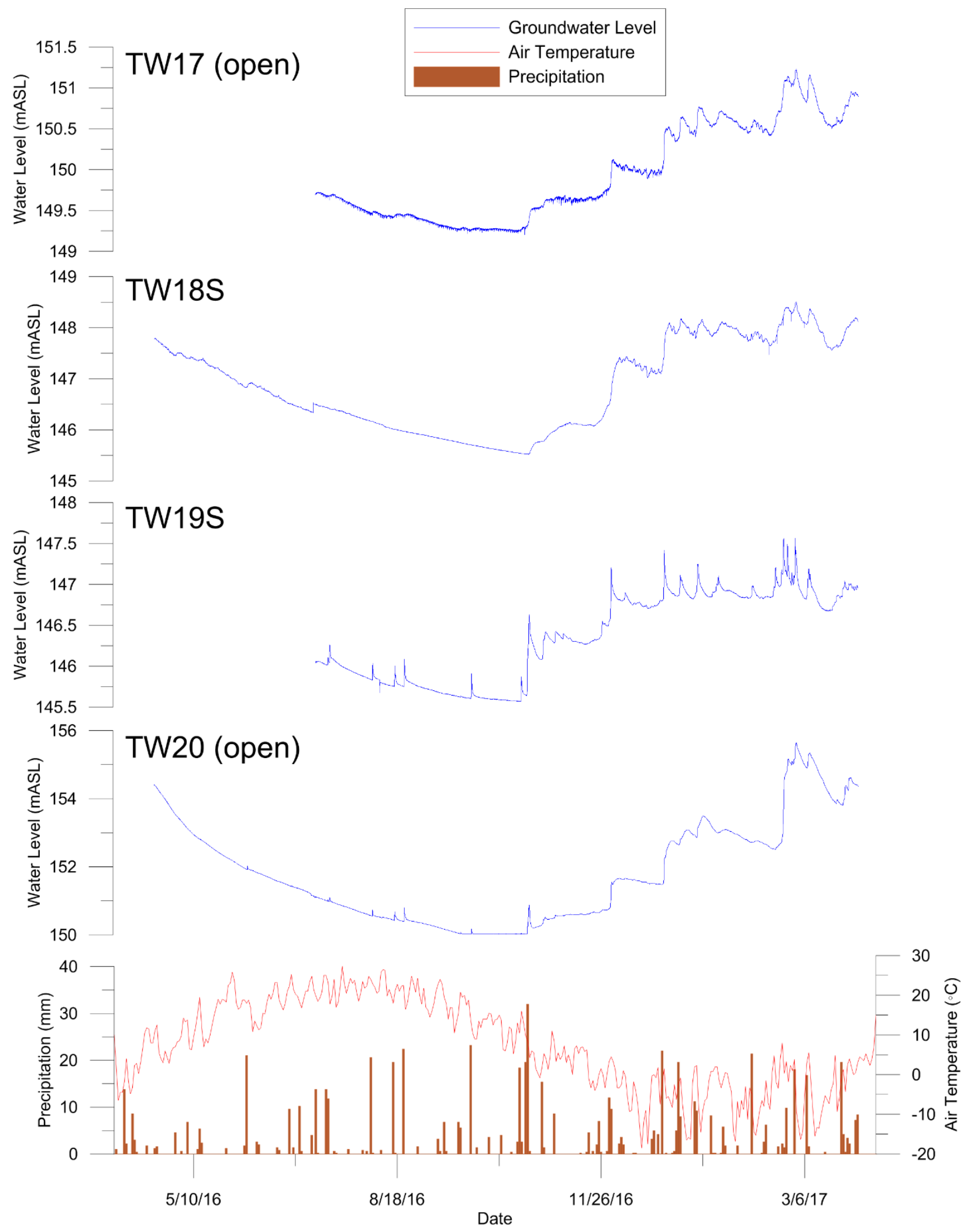


Appendix D - Farmer Survey Questionnaire 


\section{GENERAL INFORMATION}

Survey Date:

Time:

Questionnaire ID Number:

1. How many farms do you have in the aquifer? Please outline their extents and area on the map. Do any of these farms have tile drainage or irrigation?

2. What is the typical planting period for different crops (month/week)?

\begin{tabular}{|l|l|l|}
\hline Crop type & $\begin{array}{l}\text { Typical planting period } \\
\text { (please list month/week) }\end{array}$ & $\begin{array}{l}\text { Typical harvesting period } \\
\text { (please list month/week) }\end{array}$ \\
\hline Corn & & \\
\hline Soybean & & \\
\hline Wheat & & \\
\hline
\end{tabular}




\begin{tabular}{|c|c|c|c|c|c|c|c|c|c|}
\hline & \multicolumn{3}{|c|}{ Acres per Farm } & \multicolumn{3}{|c|}{$\begin{array}{l}\text { Which treated seeds and sprays } \\
\text { have been used? }\end{array}$} & \multicolumn{3}{|c|}{ Tillage Practices } \\
\hline Year & Corn & Soybeans & Wheat & Corn Hybrids & Soybean Variety & Wheat & Corn & Soybeans & Wheat \\
\hline 2016 & & & & & & & & & \\
\hline 2015 & & & & & & & & & \\
\hline 2014 & & & & & & & & & \\
\hline 2013 & & & & & & & & & \\
\hline
\end{tabular}




\section{Appendix E - Mathematical Modelling Inputs}


Hydrus 1D (version 4.16.0110) solves the Richard's equation for saturated-unsaturated water flow and Fickian-based advection-dispersion equations for solute transport (Šimůnek et al., 2013). The Ogata-Banks solution solves the advection-dispersion equation in $1 \mathrm{D}$ given a constant source concentration, the Darcy velocity, longitudinal dispersion coefficient, retardation factor, decay coefficient, and duration of contaminant input. CRAFLUSH is a one-dimensional discrete fracture network model that analytically solves the Laplace transformed solution from Sudicky and Frind (1982) and Tang et al. (1981). Inputs for CRAFLUSH include the contaminant concentration at the fracture origin, velocity in the fracture, dispersivity, aperture, spacing, matrix porosity, tortuosity, diffusion, retardation, and half-life. 
Pcp_File_Version $=4$

\section{*** BLOCK A: BASIC INFORMATION}

\section{Heading}

LP-MW-02-10

LUnit TUnit MUnit (indicated units are obligatory for all input data)

$\mathrm{cm}$

days

ppb

\begin{tabular}{|c|c|c|c|c|c|c|c|c|c|c|}
\hline & & & & & & & & & & Ilnvers \\
\hline IWat & IChem & ITemp & ISink & IRoot & IShort & IWDep & IScreen & IVariabBC & IEquil & e \\
\hline $\mathrm{t}$ & $\mathrm{t}$ & $f$ & $\mathrm{t}$ & $\begin{array}{c}f \\
\text { IActive }\end{array}$ & $\mathrm{t}$ & $f$ & $\begin{array}{c}\mathrm{t} \\
\text { IDumm }\end{array}$ & $\mathrm{t}$ & f & $f$ \\
\hline ISnow & IHP1 & IMeteo & IVapor & $U$ & IFluxes & IIrrig & $y$ & IDummy & IDummy & \\
\hline$f$ & $f$ & $f$ & $f$ & $f$ & $\mathrm{t}$ & $f$ & $f$ & $f$ & $f$ & \\
\hline NMat & NLay & CosAlpha & & & & & & & & \\
\hline 4 & 4 & 1 & & & & & & & & \\
\hline *** BLOCK B: WATER & RMATION *; & 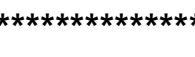 & 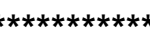 & 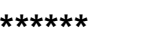 & & & & & & \\
\hline Maxlt & TolTh & TolH & (maxim & m numbe & of iteratic & s and tol & rances) & & & \\
\hline 1000 & 0.001 & 0.1 & & & & & & & & \\
\hline Toplnf & WLayer & KodTop & $\begin{array}{l}\text { InitCon } \\
\mathrm{d}\end{array}$ & & & & & & & \\
\hline $\mathrm{t}$ & f & -1 & $f$ & & & & & & & \\
\hline Botlnf & qGWLF & FreeD & SeepF & KodBot & DrainF & hSeep & & & & \\
\hline $\mathrm{t}$ & $f$ & $f$ & $f$ & 1 & $f$ & 0 & & & & \\
\hline hTab1 & hTabN & & & & & & & & & \\
\hline $1.00 \mathrm{E}-06$ & 10000 & & & & & & & & & \\
\hline Model & Hysteresis & & & & & & & & & \\
\hline 5 & 0 & & & & & & & & & \\
\hline thr & ths & Alfa & $\mathrm{n}$ & Ks & I & w2 & Alfa2 & $\mathrm{n} 2$ & & \\
\hline 0.0416 & 0.3873 & 0.03 & 1.5 & 341.46 & 0.5 & 0.5 & 0.03 & 1.5 & & \\
\hline 0.0485 & 0.3904 & 0.03 & 1.5 & 105.12 & 0.5 & 0.5 & 0.03 & 1.5 & & \\
\hline 0.1169 & 0.3854 & 0.03 & 1.5 & 80 & 0.5 & 0.5 & 0.03 & 1.5 & & \\
\hline & & & & & 146 & & & & & \\
\hline
\end{tabular}




\begin{tabular}{|c|c|c|c|c|c|c|c|c|c|c|c|c|}
\hline 0.053 & 0.3747 & 0.03 & 1.5 & 642.98 & 0.5 & 0.5 & 0.03 & 1.5 & & & & \\
\hline \multicolumn{13}{|c|}{${ }^{\star * \star}$ BLOCK C: TIME INFORMATION ${ }^{* \star \star \star \star \star \star \star \star \star \star \star ~}$} \\
\hline $\mathrm{dt}$ & dtMin & dtMax & DMul & DMul2 & ItMin & ItMax & MPL & & & & & \\
\hline $\begin{array}{c}1.00 \mathrm{E}-05 \\
\text { tlnit }\end{array}$ & $\begin{array}{l}\text { 1.00E-05 } \\
\text { tMax }\end{array}$ & 100 & 1.3 & 0.7 & 3 & 7 & 50 & & & & & \\
\hline 0 & $\begin{array}{c}183 \\
\text { nPrintStep }\end{array}$ & tPrintInterv & & & & & & & & & & \\
\hline IPrintD & $\mathrm{s}$ & al & IEnter & & & & & & & & & \\
\hline $\mathrm{t}$ & 1 & 7 & $\mathrm{t}$ & & & & & & & & & \\
\hline \multicolumn{13}{|c|}{ TPrint(1),TPrint(2),.., TPrint(MPL) } \\
\hline 3 & 6 & 9 & 12 & 15 & 18 & & & & & & & \\
\hline 21 & 24 & 27 & 30 & 33 & 36 & & & & & & & \\
\hline 39 & 42 & 45 & 48 & 51 & 54 & & & & & & & \\
\hline 57 & 60 & 63 & 66 & 69 & 72 & & & & & & & \\
\hline 75 & 78 & 81 & 84 & 87 & 90 & & & & & & & \\
\hline 93 & 96 & 99 & 102 & 105 & 108 & & & & & & & \\
\hline 111 & 114 & 117 & 120 & 123 & 126 & & & & & & & \\
\hline 129 & 132 & 135 & 138 & 141 & 144 & & & & & & & \\
\hline 147 & 183 & & & & & & & & & & & \\
\hline \multicolumn{13}{|c|}{ 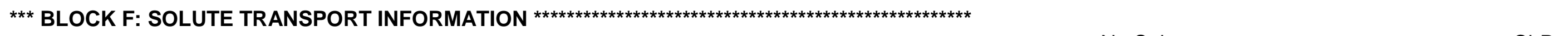 } \\
\hline Epsi & IUpW & IArtD & ITDep & cTolA & cTolR & MaxltC & $\mathrm{PeCr}$ & $\begin{array}{c}\text { No.Solute } \\
\mathrm{s}\end{array}$ & ITort & iBacter & IFiltr & $\underset{r}{\mathrm{nChPa}}$ \\
\hline 1 & f & f & f & 0.001 & 0.001 & $\begin{array}{c}10 \\
\text { IDumm }\end{array}$ & $\begin{array}{c}2 \\
\text { IDumm }\end{array}$ & 3 & $\mathrm{f}$ & 1 & $f$ & 16 \\
\hline iNonEqul & IWatDep & IDualNEq & IInitM & IInitEq & ITort & $y$ & $y$ & IDummy & IDummy & ICFTr & & \\
\hline 3 & $f$ & $f$ & $\mathrm{t}$ & $f$ & $\stackrel{f}{\mathrm{f}}$ & $f$ & $f$ & $f$ & $f$ & $\mathrm{t}$ & & \\
\hline Bulk.d. & DisperL. & Frac & Mobile & WC & ) & & & & & & & \\
\hline $1.60 \mathrm{E}+06$ & 5 & 0 & 0 & & & & & & & & & \\
\hline $1.40 \mathrm{E}+06$ & 20 & 0 & 0 & & & & & & & & & \\
\hline $1.70 \mathrm{E}+06$ & 100 & 0 & 0 & & & & & & & & & \\
\hline $1.40 \mathrm{E}+06$ & 210 & 0 & 0 & & & & & & & & & \\
\hline
\end{tabular}




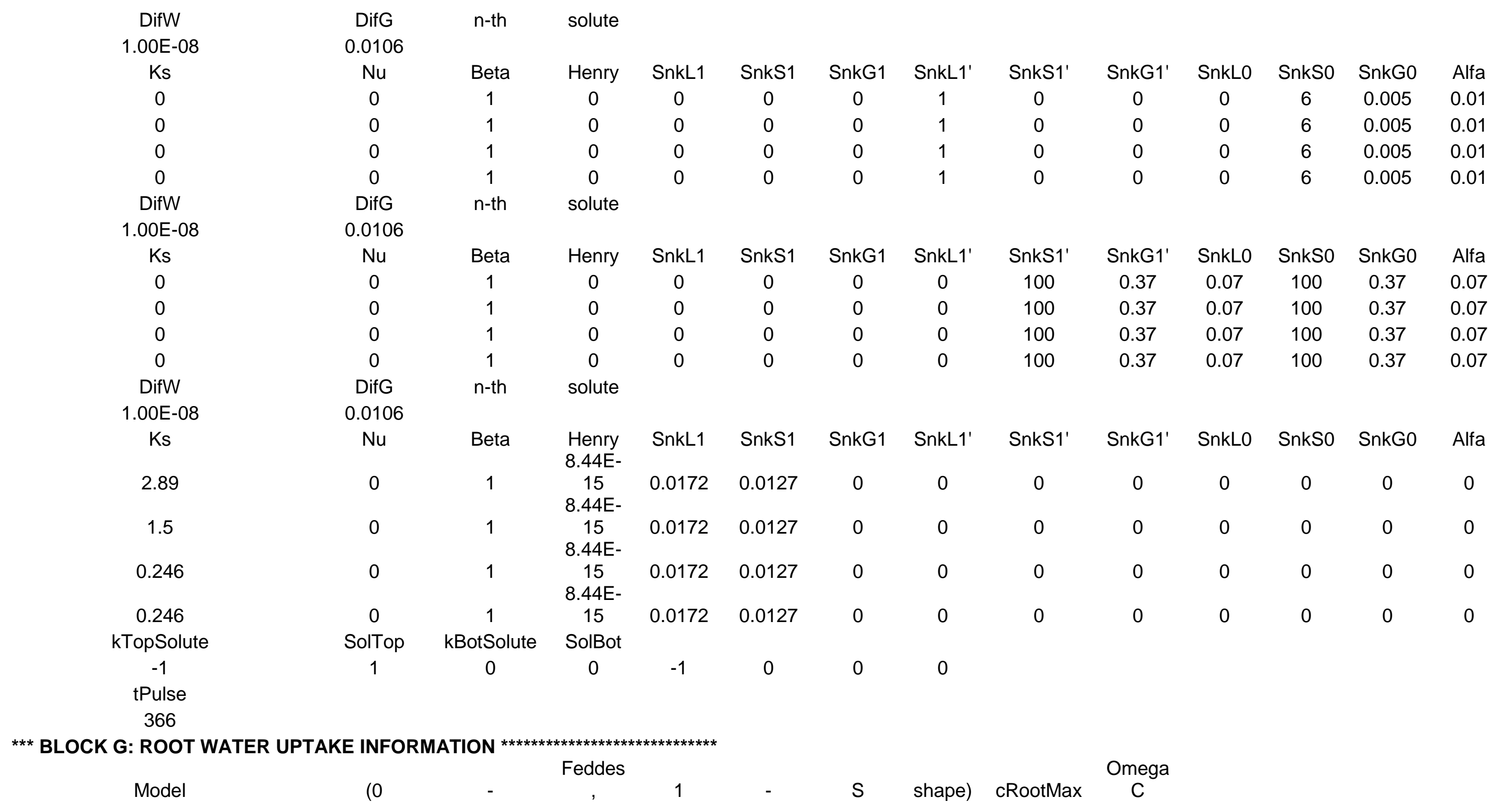




$\begin{array}{cccccc}0 & 0 & 0 & 0 & 1 & \\ \text { P0 } & \text { P2H } & \text { P2L } & \text { P3 } & \text { r2H } & \text { r2L } \\ -15 & -325 & -600 & -8000 & 0.5 & 0.1 \\ \text { POptm(1),POptm(2),..,POptm(NM } & & & & & \\ \text { at) } & & & & & \\ -30 & -30 & -30 & -30 & & \\ \text { Solute } & \text { Reduction } & & & & \\ f & & & & \end{array}$


Pcp_File_Version $=4$

\section{*** BLOCK A: BASIC INFORMATION}

Heading

TW17

LUnit TUnit MUnit (indicated units are obligatory for all input data)

$\mathrm{cm}$

days

$\mathrm{ppb}$

IWat IChem ITemp

$t \quad f \quad$ IMeteo

ISink IRoot IShort

$\mathrm{t}$

ISnow

f

$f \quad f$

NMat

NLay

CosAlpha

\section{*** BLOCK B: WATER FLOW INFORMATION}

Maxlt TolTh TolH

$10 \quad 0.001$

TopInf WLayer KodTop

$t \quad f$

$f$

Botinf

qGWLF

Freed 0.1

(maximum number of iterations and tolerances)

$\mathrm{t}$

InitCond

$-1 \mathrm{f}$

hTab1 hTabN

1.00E-06 10000

Model Hysteresis

50

ths Alf

$0.0411 \quad 0.3858$

Alfa 0.05

n 5

Ks 0.8

$\begin{array}{lll} & \text { I } & \\ & 0.1\end{array}$

w2 $\quad \begin{array}{cc}\text { Alfa2 } & \mathrm{n} 2 \\ 0.5 & 0.03\end{array}$

1.5

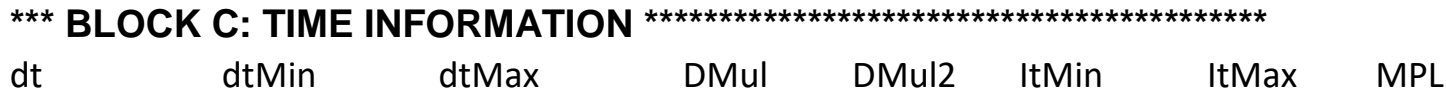




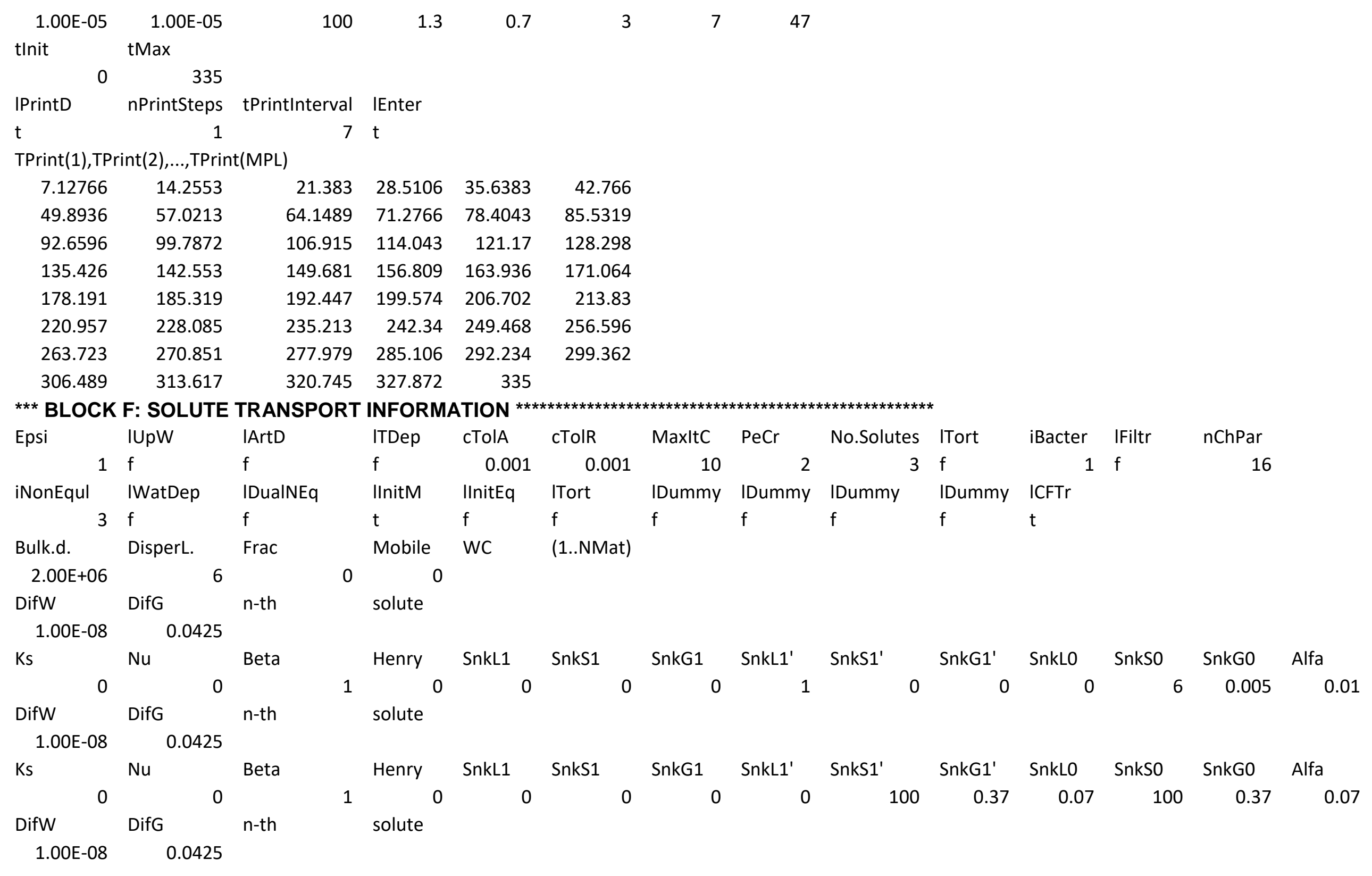




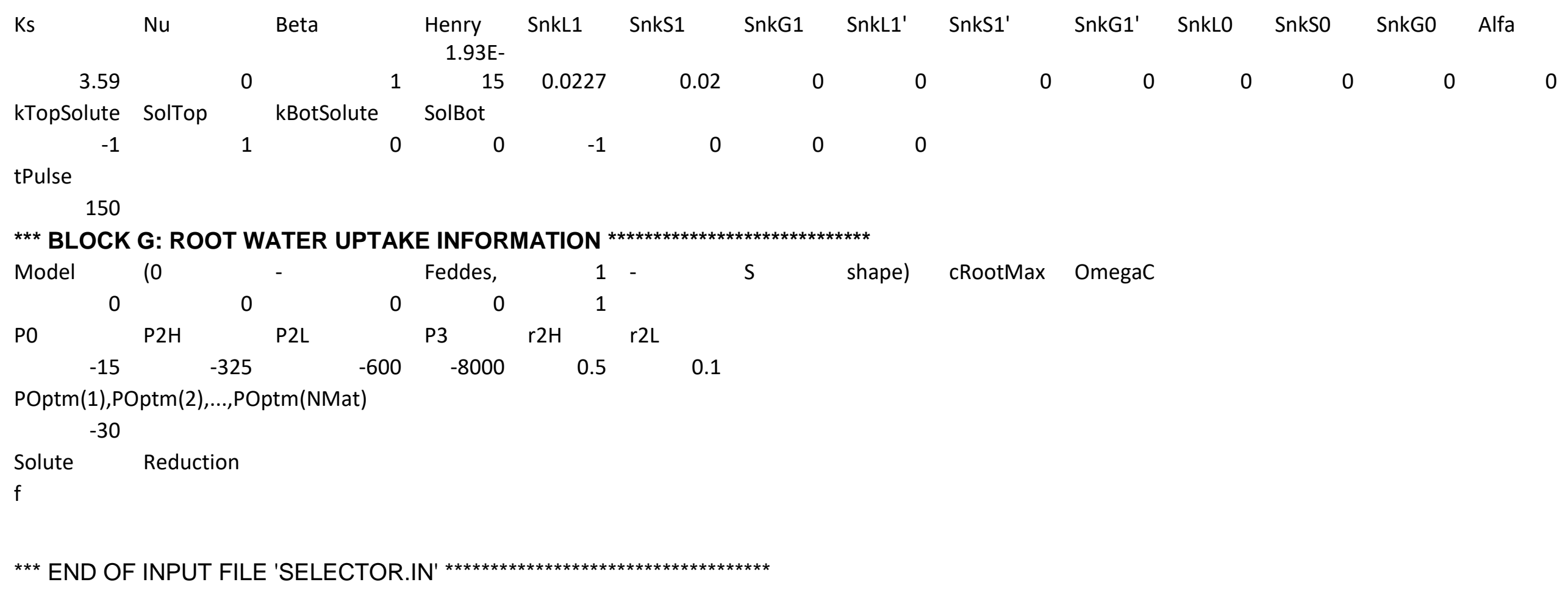


Pcp_File_Version $=4$

${ }^{* * *}$ BLOCK A: BASIC INFORMATION

Heading

LP-MW-02-10 with Increased Spin-Up (Starting in September 2014)

LUnit TUnit MUnit (indicated units are obligatory for all input data)

$\mathrm{cm}$

days

$\mathrm{ppb}$

IWat IChem ITemp ISink IRoot IShort IWDep IScreen IVariabBC IEquil IInverse

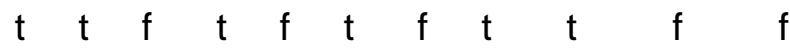

ISnow IHP1 IMeteo IVapor IActiveU IFluxes IIrrig IDummy IDummy IDummy

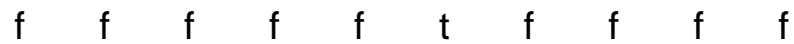

NMat NLay CosAlpha

$\begin{array}{lll}4 & 4 & 1\end{array}$

*** BLOCK B: WATER FLOW INFORMATION ***

Maxlt TolTh TolH

(maximum number of iterations and tolerances)

$1000 \quad 0.001 \quad 0.1$ 
TopInf WLayer KodTop InitCond

$\begin{array}{llll}t & f & -1 & f\end{array}$

BotInf qGWLF FreeD SeepF KodBot DrainF hSeep

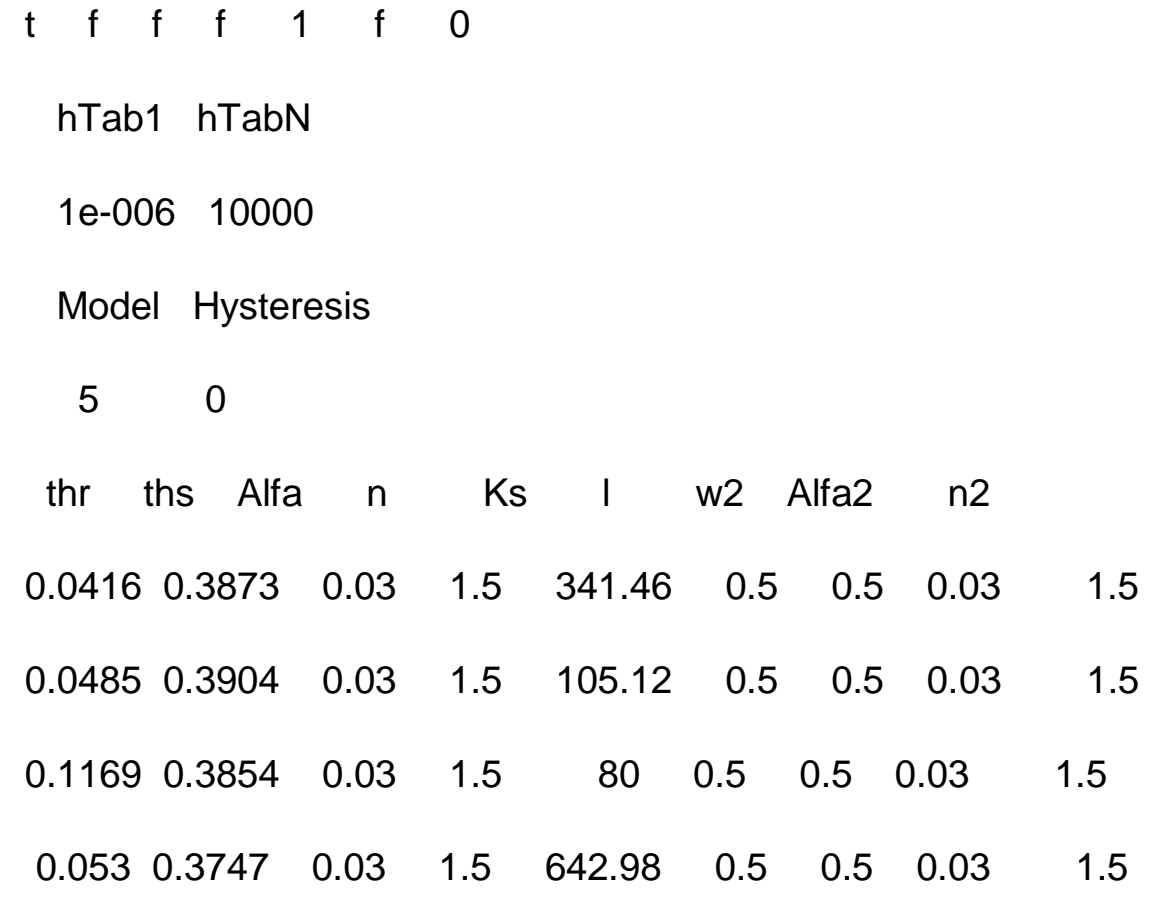

dt dtMin dtMax DMul DMul2 ItMin ItMax MPL

$\begin{array}{llllllll}\text { 1e-005 } & 1 \mathrm{e}-005 & 100 & 1.3 & 0.7 & 3 & 7 & 50 \\ \text { tlnit } & \text { tMax } & & & & & & \\ \end{array}$


$-618 \quad 184$

IPrintD nPrintSteps tPrintInterval IEnter

$\begin{array}{llll}\mathrm{t} & 1 & 7 & \mathrm{t}\end{array}$

TPrint(1),TPrint(2),...,TPrint(MPL)

$\begin{array}{llllll}3 & 6 & 9 & 12 & 15 & 18 \\ 21 & 24 & 27 & 30 & 33 & 36 \\ 39 & 42 & 45 & 48 & 51 & 54 \\ 57 & 60 & 63 & 66 & 69 & 72 \\ 75 & 78 & 81 & 84 & 87 & 90 \\ 93 & 96 & 99 & 102 & 105 & 108 \\ 111 & 114 & 117 & 120 & 123 & 126 \\ 129 & 132 & 135 & 138 & 141 & 144 \\ 147 & 183 & & & & \end{array}$

*** BLOCK F: SOLUTE TRANSPORT INFORMATION

Epsi IUpW IArtD ITDep cTolA cTolR MaxltC PeCr No.Solutes ITort iBacter IFiltr nChPar

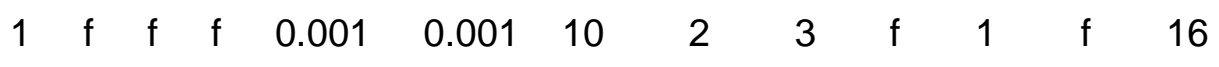

iNonEqul IWatDep IDualNEq IInitM IInitEq ITort IDummy IDummy IDummy IDummy ICFTr 
Bulk.d. DisperL. Frac Mobile WC (1..NMat)

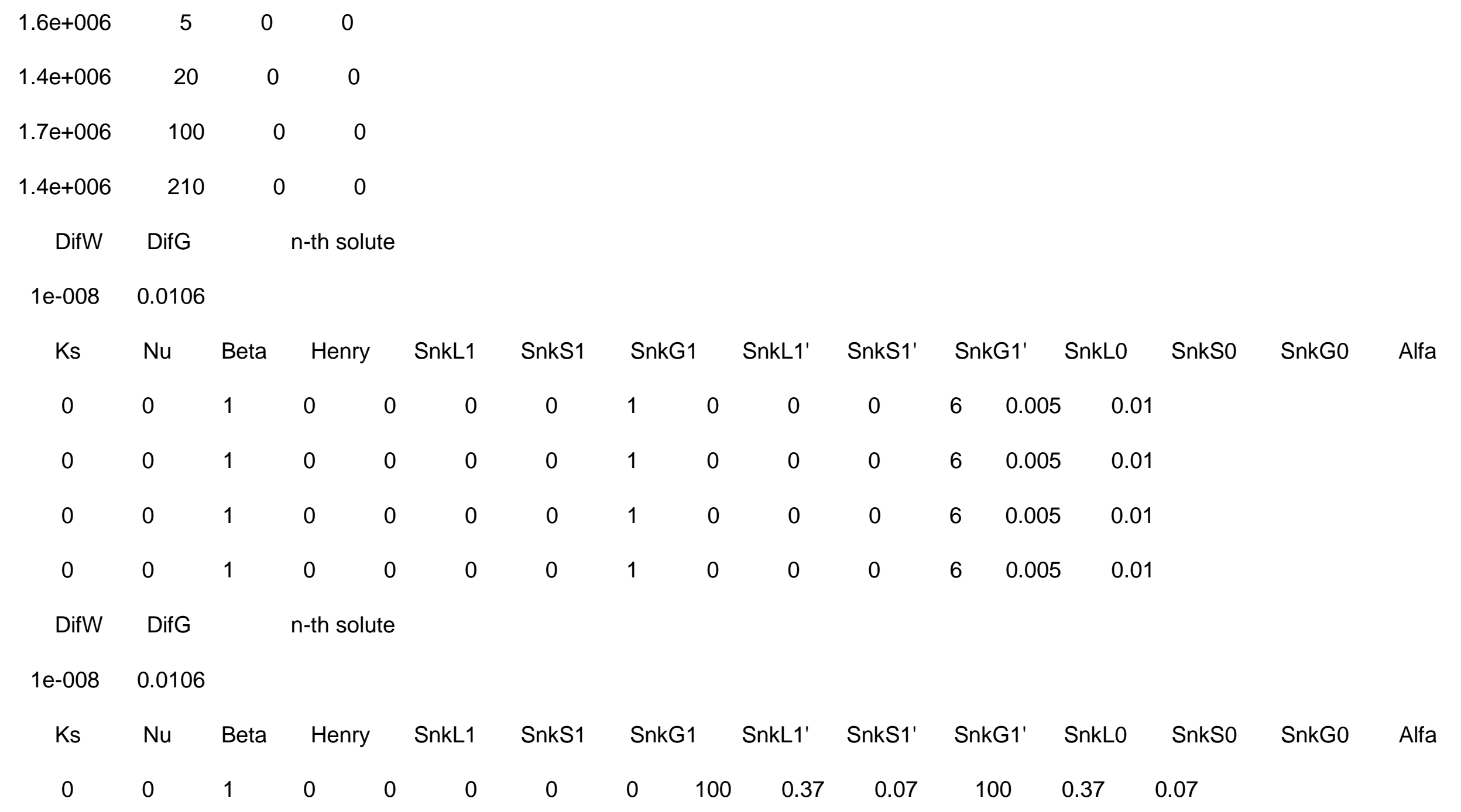




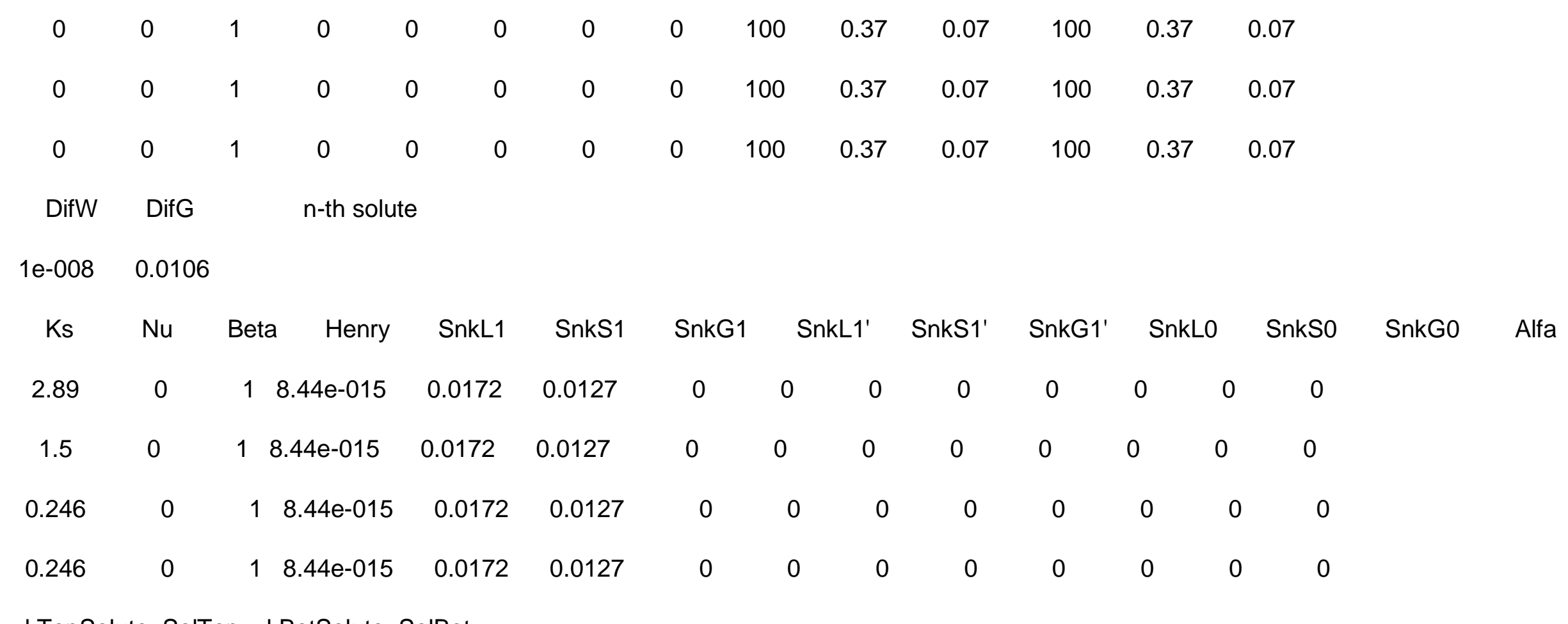

kTopSolute SolTop kBotSolute SolBot

$\begin{array}{llllllll}-1 & 1 & 0 & 0 & -1 & 0 & 0 & 0\end{array}$

tPulse

366

*** BLOCK G: ROOT WATER UPTAKE INFORMATION

Model (0 - Feddes, 1 - S shape) cRootMax OmegaC
0
$0 \quad 0$ 


$\begin{array}{llllll}\mathrm{P} 2 \mathrm{H} & \mathrm{P} 2 \mathrm{~L} & \mathrm{P} 3 & \mathrm{r} 2 \mathrm{H} & \mathrm{r} 2 \mathrm{~L}\end{array}$

$\begin{array}{llllll}-15 & -325 & -600 & -8000 & 0.5 & 0.1\end{array}$

POptm(1),POptm(2),...,POptm(NMat)

$\begin{array}{llll}-30 & -30 & -30 & -30\end{array}$

Solute Reduction

f

\section{${ }^{\star * *}$ END OF INPUT FILE 'SELECTOR.IN'}

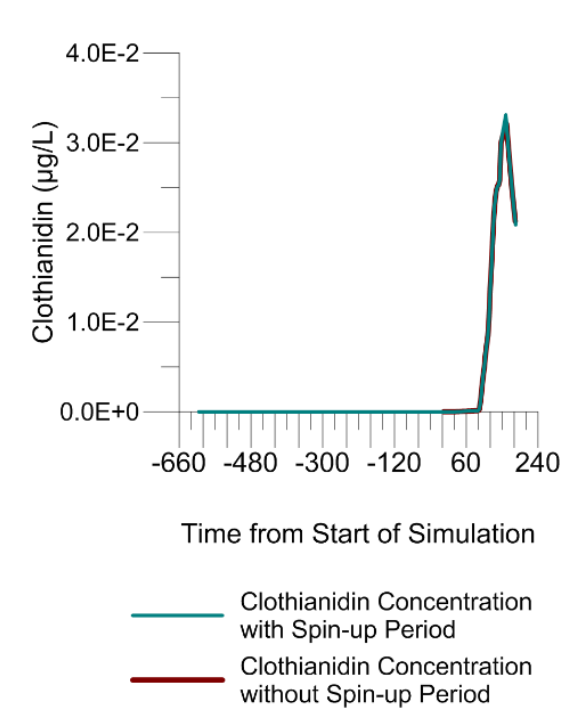

The above graph shows clothianidin release through the LP-MW-02 model with a spin-up period and no spin-up period. A modified contaminant input needed to be used for this scenario in order to accommodate the contaminant input that occurs part-way through the simulation. As a result, the magnitudes of these peaks are not consistent with other modelling scenarios. However, this exercise did display that a spin-up period did not influence the release pattern of clothianidin from the saturated subsurface. 






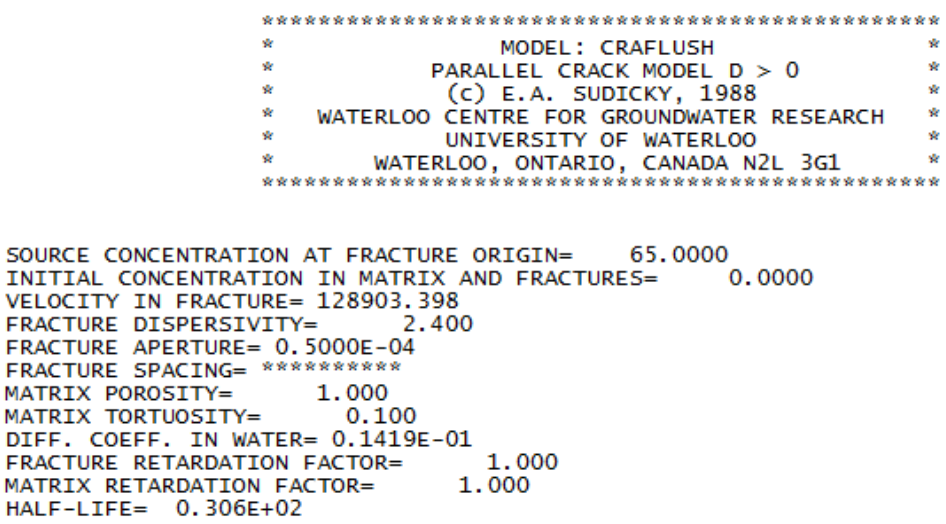

\begin{tabular}{|c|c|c|c|c|c|}
\hline TIME & DISTANCE : & ALONG FRACTURE, & IN MATRIX & $c(t)$ & STEADY C \\
\hline $14155 E-03$ & & 0.000 & 0.000 & 65.0000000 & 65.000000 \\
\hline $14155 \mathrm{E}-03$ & & 1.000 & 0.000 & 44.6607011 & 64.8862152 \\
\hline $14155 \mathrm{E}-03$ & & 2.000 & 0.000 & 29.5031975 & 64.7726288 \\
\hline $14155 \mathrm{E}-03$ & & 3.000 & 0.000 & 18.7813865 & 64.6592331 \\
\hline $14155 \mathrm{E}-03$ & & 4.000 & 0.000 & 11.5500002 & 64.5460434 \\
\hline $14155 \mathrm{E}-03$ & & 5.000 & 0.000 & 6.8731333 & 64.4330521 \\
\hline $14155 \mathrm{E}-03$ & & 6.000 & 0.000 & 3. 9643288 & 64.3202591 \\
\hline $14155 \mathrm{E}-03$ & & 7.000 & 0.000 & 2. 2192807 & 64.2076645 \\
\hline $14155 \mathrm{E}-03$ & & 8.000 & 0.000 & 1. 2072940 & 64.0952606 \\
\hline $14155 \mathrm{E}-03$ & & 9.000 & 0.000 & 0.6388987 & 63.9830589 \\
\hline $14155 \mathrm{E}-03$ & & 10.000 & 0.000 & 0.3292251 & 63.8710518 \\
\hline $14155 \mathrm{E}-03$ & & 11.000 & 0.000 & 0.1653339 & 63.7592392 \\
\hline$E-03$ & & 12.000 & 0.000 & 0.0809799 & 63.6476250 \\
\hline$E-03$ & & 13.000 & 0.000 & 0.0387117 & 63.5362091 \\
\hline-03 & & 14.000 & 0.000 & 0.0180730 & 63.4249840 \\
\hline$E-03$ & & 15.000 & 0.000 & 0.0082451 & 63.3139534 \\
\hline$E-03$ & & 16.000 & 0.000 & 0.0036777 & 63.20311 \\
\hline 141 & & 17.000 & 0.000 & 0.0016046 & 63.0924759 \\
\hline-03 & & 18.000 & 0.000 & 0.0006852 & 62.9820290 \\
\hline 03 & & 19.000 & 0.000 & 0.0002864 & 62.8717728 \\
\hline-03 & & 20.000 & 0.000 & 0.0001173 & 62.7617111 \\
\hline & & 21.000 & 0.000 & 0.0000471 & 62.6518440 \\
\hline-03 & & 22.000 & 0.000 & 0.0000185 & 62.5421677 \\
\hline 03 & & 23.000 & 0.000 & 0.0000071 & 62.4326820 \\
\hline 03 & & 24.000 & 0.000 & 0.0000027 & 62.3233871 \\
\hline-03 & & 25.000 & 0.000 & 0.0000010 & 62.2142 \\
\hline-1 & & 26. & 0.000 & 0.0000004 & 62.105 \\
\hline 03 & & 27.000 & 0. & 0.0000 & 61.996 \\
\hline 03 & & 28.000 & 0.000 & 0.0000000 & 61.8881302 \\
\hline 03 & & 29. & 0.000 & 0.0000 & 61.77978 \\
\hline 03 & & 30.000 & 0.000 & 0.0000000 & 61.671638 \\
\hline & & 31. & & 0.0000 & 61.563 \\
\hline 03 & & 32.000 & 0.000 & 0.0000 & 61.455 \\
\hline & & 33.000 & 0.000 & 0.0000000 & 61.3483238 \\
\hline 3 & & 34.000 & & 0.0000 & 61.240 \\
\hline & & 35.000 & 0. & 0.0000000 & 61.1337242 \\
\hline & & & 0 . & 0.0000000 & 61.026706 \\
\hline-0 & & 000 & 0.000 & 0.0000000 & 60.9198723 \\
\hline & & & & 0.0000 & 60.813 \\
\hline & & 0 & 0 . & 0.0000000 & 60.7067 \\
\hline $14+$ & & 40.000 & 0.000 & 0.0000000 & 60.6005020 \\
\hline
\end{tabular}


Ogata-Banks Manual Calculations (with Retardation)

$$
C(x, t)=\frac{1}{2} C_{o}\left[\operatorname{erfc}\left(\frac{x-\frac{v}{R} t}{\sqrt{4 \frac{D}{R} t}}\right)+e^{v \frac{x}{D}} * \operatorname{erfc}\left(\frac{x-\frac{v}{R} t}{\sqrt{4 \frac{D}{R} t}}\right)\right]
$$

$C_{o}:$ Source concentration $\left(\frac{\mu g}{L}\right)$

v: Average linear groundwater velocity $\left(\frac{m}{d}\right)$

$D:$ Dispersion $\left(\frac{m^{2}}{d}\right)$

$R:$ Retardation factor $(-)$

$C(x, t)$ : Concentration at point $x(m)$ and time $t(d)$

$K$ : Hydraulic Conductivity for Sand $\left(\frac{m}{d}\right)$

$i$ : Hydraulic Gradient (-)

$n$ : Porosity (-)

$\alpha_{L}:$ Longitudinal Dispersivity $(m)$

$\rho_{b}$ : Bulk Density of sand $\left(\frac{\mathrm{g}}{\mathrm{cm}^{3}}\right)$

$K_{O C}$ : Soil Organic Carbon-Water Partitioning Coefficient $\left(\frac{\mathrm{cm}^{3}}{\mathrm{~g}}\right)$

$f_{\text {OC }}$ : Organic carbon content in soil (-)

$K_{d}$ : Distribution Coefficient $\left(\frac{\mathrm{cm}^{3}}{\mathrm{~g}}\right)$

$K=518.40 \frac{m}{d}$ (Domenico and Schwartz, 1990)

$i=0.002$ (obtained from pressure transducer data in April 2016)

$n=0.25$ (Domenico and Schwartz, 1990)

$\alpha_{L}=2 m$ (Gelhar et al., 1992)

$\rho_{b}: 1.7 \frac{\mathrm{g}}{\mathrm{cm}^{3}}$ (United States Department of Agriculture, 2017)

$K_{O C}=123 \frac{\mathrm{cm}^{3}}{\mathrm{~g}}$ (Pesticide Properties Database, 2017)

$f_{\text {OC }}=0.002$ (US EPA, 1996)

$v=K \frac{i}{n}=518.40 \frac{\mathrm{m}}{\mathrm{d}} * \frac{0.002}{0.25}=4.15 \frac{\mathrm{m}}{\mathrm{d}}$

$D=\alpha_{L} v=2 m * 4.15 \frac{m}{d}=8.30 \frac{m^{2}}{d}$

$K_{d}=K_{O C} * f_{O C}=123 \frac{\mathrm{cm}^{3}}{\mathrm{~g}} * 0.002=0.246 \frac{\mathrm{cm}^{3}}{\mathrm{~g}}$

$R=1+\frac{\rho_{b} K_{d}}{n}=1+\frac{1.7 \frac{g}{\mathrm{~cm}^{3}} * 0.246 \frac{\mathrm{cm}^{3}}{\mathrm{~g}}}{0.25}=1.67$ 
Sample Calculation:

$$
\begin{aligned}
& C(x, t)=\frac{1}{2} C_{o}\left[\operatorname{erfc}\left(\frac{x-\frac{v}{R} t}{\sqrt{4 \frac{D}{R} t}}\right)+e^{v \frac{x}{D}} * \operatorname{erfc}\left(\frac{x+\frac{v}{R} t}{\sqrt{4 \frac{D}{R} t}}\right)\right] \\
& C(30,10)=\frac{1}{2}(0.15)\left[\operatorname{erfc}\left(\frac{30-\frac{4.15}{1.67} 10}{\sqrt{4 \frac{8.30}{1.67} 10}}\right)+e^{4.15 \frac{10}{8.30}} * \operatorname{erfc}\left(\frac{30+\frac{4.15}{1.67} 10}{\sqrt{4 \frac{8.30}{1.67} 10}}\right)\right] \\
& C(30,10)=(0.075)\left[\operatorname{erfc}\left(\frac{5.1497}{\sqrt{198.802}}\right)+e^{5} * \operatorname{erfc}\left(\frac{54.8503}{\sqrt{198.802}}\right)\right] \\
& C(30,10)=(0.075)[0.60549+(148.4132 * 0)] \\
& C(30,10)=0.0454 \frac{\mu g}{L}
\end{aligned}
$$


Outputs:

\begin{tabular}{|c|c|c|c|c|c|c|c|c|}
\hline $\begin{array}{c}\mathrm{C}(\mathrm{x}, \mathrm{t}) \\
(\mu \mathrm{g} / \mathrm{L})\end{array}$ & $\begin{array}{c}\mathrm{C} \\
(\mathrm{x}, 1 \mathrm{~d})\end{array}$ & $\begin{array}{c}\mathrm{C} \\
(\mathrm{x}, 5 \mathrm{~d})\end{array}$ & $\begin{array}{c}\mathrm{C} \\
(\mathrm{x}, 10 \mathrm{~d})\end{array}$ & $\begin{array}{c}\mathrm{C} \\
(\mathrm{x}, 24 \mathrm{~d})\end{array}$ & $\begin{array}{c}\mathrm{C} \\
(\mathrm{x}, 49 \mathrm{~d})\end{array}$ & $\begin{array}{c}\mathrm{C} \\
(\mathrm{x}, 65 \mathrm{~d})\end{array}$ & $\begin{array}{c}\mathrm{C} \\
(\mathrm{x}, 81 \mathrm{~d})\end{array}$ & $\begin{array}{c}\mathrm{C} \\
(\mathrm{x}, 101 \mathrm{~d})\end{array}$ \\
\hline $\begin{array}{c}\text { Concentration } \\
\text { at } 10 \mathrm{~m}\end{array}$ & $2.13 \mathrm{E}-03$ & $1.12 \mathrm{E}-01$ & $1.45 \mathrm{E}-01$ & $1.50 \mathrm{E}-01$ & $1.50 \mathrm{E}-01$ & $1.50 \mathrm{E}-01$ & $1.50 \mathrm{E}-01$ & $1.50 \mathrm{E}-01$ \\
\hline $\begin{array}{c}\text { Concentration } \\
\text { at 30m }\end{array}$ & $0.00 \mathrm{E}+00$ & $9.66 \mathrm{E}-04$ & $4.54 \mathrm{E}-02$ & $1.46 \mathrm{E}-01$ & $1.50 \mathrm{E}-01$ & $1.50 \mathrm{E}-01$ & $1.50 \mathrm{E}-01$ & $1.50 \mathrm{E}-01$ \\
\hline $\begin{array}{c}\text { Concentration } \\
\text { at 50m }\end{array}$ & $0.00 \mathrm{E}+00$ & $0.00 \mathrm{E}+00$ & $8.83 \mathrm{E}-04$ & $1.10 \mathrm{E}-01$ & $1.50 \mathrm{E}-01$ & $1.50 \mathrm{E}-01$ & $1.50 \mathrm{E}-01$ & $1.50 \mathrm{E}-01$ \\
\hline $\begin{array}{c}\text { Concentration } \\
\text { at 100m }\end{array}$ & $0.00 \mathrm{E}+00$ & $0.00 \mathrm{E}+00$ & $0.00 \mathrm{E}+00$ & $6.86 \mathrm{E}-04$ & $1.26 \mathrm{E}-01$ & $1.49 \mathrm{E}-01$ & $1.50 \mathrm{E}-01$ & $1.50 \mathrm{E}-01$ \\
\hline $\begin{array}{c}\text { Concentration } \\
\text { at } 160 \mathrm{~m}\end{array}$ & $0.00 \mathrm{E}+00$ & $0.00 \mathrm{E}+00$ & $0.00 \mathrm{E}+00$ & $0.00 \mathrm{E}+00$ & $6.28 \mathrm{E}-03$ & $7.86 \mathrm{E}-02$ & $1.39 \mathrm{E}-01$ & $1.50 \mathrm{E}-01$ \\
\hline
\end{tabular}

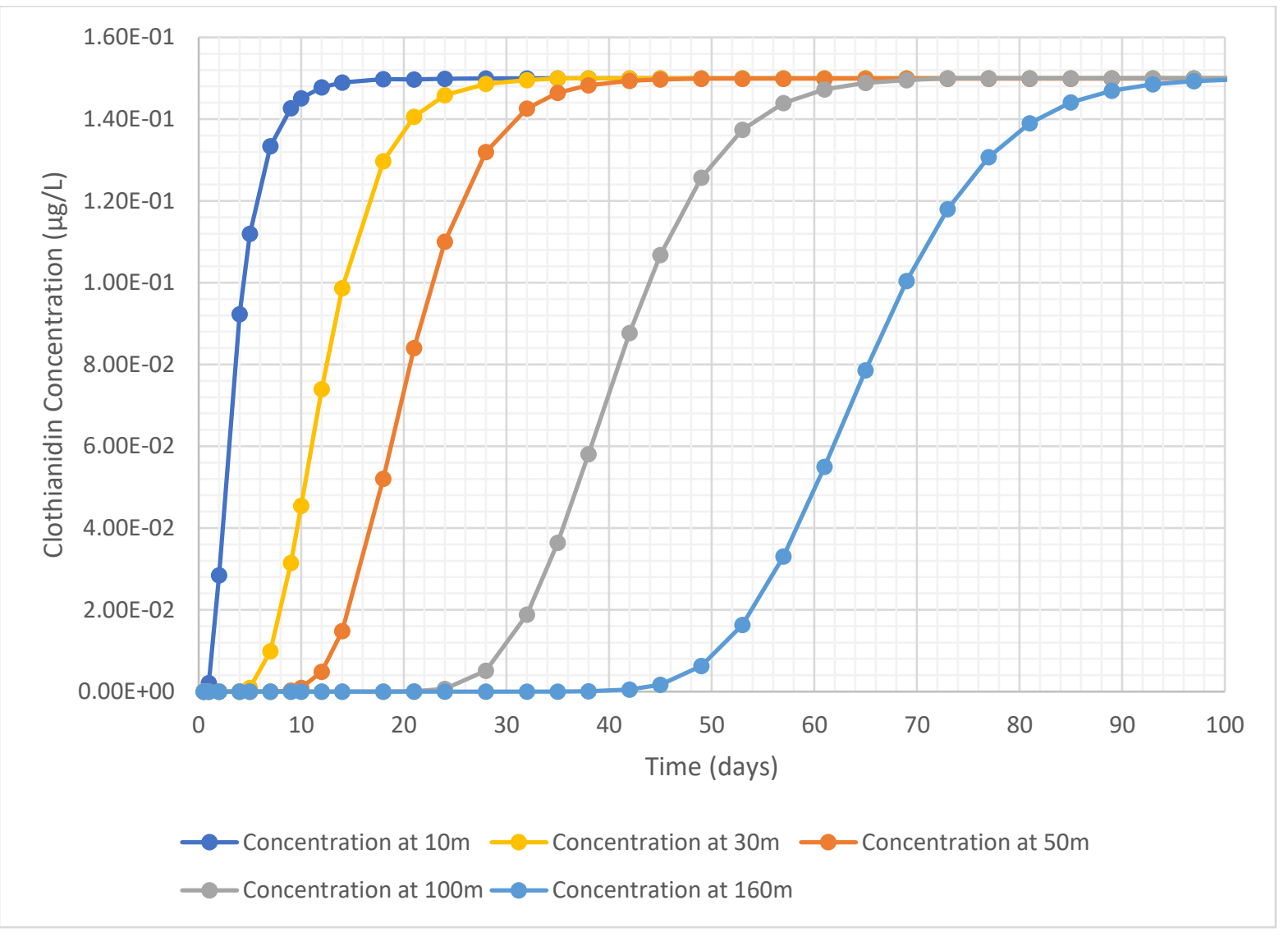




\begin{tabular}{|c|c|c|c|c|c|c|c|c|c|}
\hline $\begin{array}{c}\mathrm{C} / \mathrm{C}_{\mathrm{o}}(\mathrm{x}, \mathrm{t}) \\
(\mu \mathrm{g} / \mathrm{L})\end{array}$ & $\begin{array}{c}\mathrm{C} \\
(\mathrm{x}, 1 \mathrm{~d})\end{array}$ & $\begin{array}{c}\mathrm{C} \\
(\mathrm{x}, 5 \mathrm{~d})\end{array}$ & $\begin{array}{c}\mathrm{C} \\
(\mathrm{x}, 10 \mathrm{~d})\end{array}$ & $\begin{array}{c}\mathrm{C} \\
(\mathrm{x}, 2 \mathrm{~d})\end{array}$ & $\begin{array}{c}\mathrm{C} \\
(\mathrm{x}, 35 \mathrm{~d})\end{array}$ & $\begin{array}{c}\mathrm{C} \\
(\mathrm{x}, 49 \mathrm{~d})\end{array}$ & $\begin{array}{c}\mathrm{C} \\
(\mathrm{x}, 65 \mathrm{~d})\end{array}$ & $\begin{array}{c}\mathrm{C} \\
(\mathrm{x}, 81 \mathrm{~d})\end{array}$ & $\begin{array}{c}\mathrm{C} \\
(\mathrm{x}, 101 \mathrm{~d})\end{array}$ \\
\hline $\begin{array}{c}\text { Relative } \\
\begin{array}{c}\text { Concentration } \\
\text { at 10m }\end{array}\end{array}$ & 0.01 & 0.75 & 0.97 & 1.00 & 1.00 & 1.00 & 1.00 & 1.00 & 1.00 \\
\hline $\begin{array}{c}\text { Relative } \\
\text { Concentration } \\
\text { at 30m }\end{array}$ & 0.00 & 0.01 & 0.30 & 0.97 & 1.00 & 1.00 & 1.00 & 1.00 & 1.00 \\
\hline $\begin{array}{c}\text { Relative } \\
\text { Concentration } \\
\text { at 50m }\end{array}$ & 0.00 & 0.00 & 0.01 & 0.73 & 0.98 & 1.00 & 1.00 & 1.00 & 1.00 \\
\hline $\begin{array}{c}\text { Relative } \\
\text { Concentration } \\
\text { at 100m }\end{array}$ & 0.00 & 0.00 & 0.00 & 0.00 & 0.24 & 0.84 & 0.99 & 1.00 & 1.00 \\
\hline $\begin{array}{c}\text { Relative } \\
\text { Concentration } \\
\text { at 160m }\end{array}$ & 0.00 & 0.00 & 0.00 & 0.00 & 0.00 & 0.04 & 0.52 & 0.93 & 1.00 \\
\hline
\end{tabular}

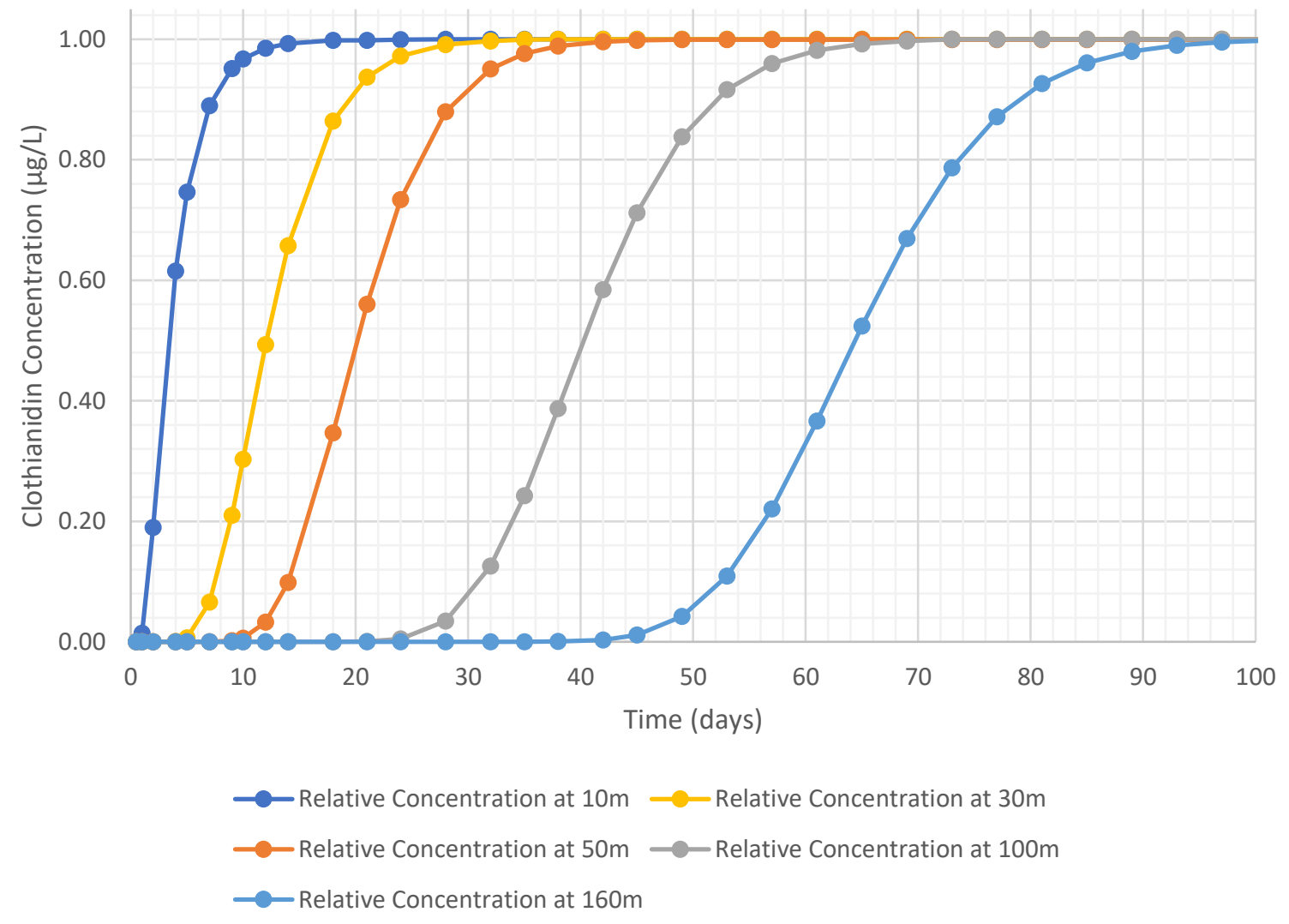


Tang Solution Manual Calculations (neglecting longitudinal dispersion)

$$
C(x, t)=\frac{1}{2} C_{o}\left[e^{-\frac{\lambda R x}{v}}\right]\left[e^{\left(-\frac{\sqrt{\lambda} R x}{v A}\right)} \operatorname{erfc}\left(\frac{x}{2 v A T^{\prime}}-\sqrt{\lambda} T^{\prime}\right)+e^{\left(-\frac{\sqrt{\lambda} R x}{v A}\right)} \operatorname{erfc}\left(\frac{x}{2 v A T^{\prime}}+\sqrt{\lambda} T^{\prime}\right)\right]
$$

$C_{o}:$ Source concentration $\left(\frac{\mu g}{L}\right)$

v: Groundwater velocity through fracture $\left(\frac{m}{d}\right)$

$\lambda$ : Decay Constant $\left(d^{-1}\right)$

$R:$ Retardation factor $(-)$

$C(x, t)$ : Concentration at point $x(m)$ and time $t(d)$

$K$ : Fracture hydraulic conductivity $\left(\frac{m}{s}\right)$

$2 b$ : Fracture Aperture $(m)$

$\rho:$ Water density $\left(\frac{\mathrm{g}}{\mathrm{cm}^{3}}\right)$

$\rho_{b}$ : Bulk density of the matrix $\left(\frac{\mathrm{g}}{\mathrm{cm}^{3}}\right)$

$\mu:$ Water Viscosity $\left(\frac{N * S}{m^{3}}\right)$

$i$ : Hydraulic Gradient (-)

$\theta$ : Fracture Porosity (-)

$K_{O C}:$ Soil Organic Carbon-Water Partitioning Coefficient $\left(\frac{\mathrm{cm}^{3}}{\mathrm{~g}}\right)$

$f_{O C}:$ Organic carbon content in soil (-)

$K_{d}$ : Distribution Coefficient $\left(\frac{\mathrm{cm}^{3}}{\mathrm{~g}}\right)$

$\tau$ : Fracture tortuosity (-)

$D^{*}:$ Molecular Diffusion Coefficent in Free Water $\left(\frac{m^{2}}{d}\right)$

Half-life $=30.6$ d for thiamethoxam in the water phase (Pesticide Properties Database, 2017)

$2 b=5\left(10^{-4}\right) m$ (Praamsma, 2016)

$\rho: 1000 \frac{\mathrm{kg}}{\mathrm{m}^{3}}$

$\mu: 0.001 \frac{N * s}{m^{2}}$

$i=0.02$ (obtained from regional pressure transducer data from April 2016)

$\theta=1$ (fracture porosity)

$K_{f}=K_{M}=0$ (no organic matter in crystalline fractured bedrock)

$D^{*}=3.89\left(10^{-5}\right) \frac{m^{2}}{d}$ (Praamsma, 2016)

$\tau=0.1$ (Praamsma, 2016) 


$$
\begin{aligned}
& \lambda=\frac{\ln (2)}{\text { Half-life }(d)}=\frac{\ln (2)}{30.6 d}=0.023 d^{-1} \\
& K=\frac{\rho g(2 \mathrm{~b})^{2}}{12 \mu}=\frac{1000 \frac{\mathrm{kg}}{\mathrm{m}^{3}} * 9.81 \frac{\mathrm{N}}{\mathrm{kg}} *\left(5 * 10^{-5}\right)^{2}}{12 * 0.001 \frac{\mathrm{N} * \mathrm{~S}}{\mathrm{~kg}}}=0.204 \frac{\mathrm{m}}{\mathrm{s}}=17,658 \frac{\mathrm{m}}{\mathrm{d}} \\
& v=K \frac{i}{\theta}=17,658 \frac{m}{d} * \frac{0.02}{1}=353.16 \frac{\mathrm{m}}{\mathrm{d}} \\
& R=1+\frac{K_{f}}{b}=1+0=1 \\
& T^{\prime}=\sqrt{t-\frac{R z}{v}}=\sqrt{t-\frac{x}{353.16 \frac{m}{d}}} \\
& D^{\prime}=\tau D^{*}=0.1 * 3.89\left(10^{-5}\right) \frac{m^{2}}{d}=3.89\left(10^{-6}\right) \frac{m^{2}}{d} \\
& R^{\prime}=1+\frac{\rho_{b} K_{M}}{\theta}=1+0=1 \\
& A=\frac{b R}{\theta \sqrt{R^{\prime} D^{\prime}}}=\frac{2.5\left(10^{-5}\right) m * 1}{1 \sqrt{1 * 3.89\left(10^{-6}\right) \frac{m^{2}}{d}}}=0.0127
\end{aligned}
$$

Sample Calculation:

$$
\begin{aligned}
& C(x, t)=\frac{1}{2} C_{o}\left[e^{-\frac{\lambda R x}{v}}\right]\left[e^{\left(-\frac{\sqrt{\lambda} R x}{v A}\right)} \operatorname{erfc}\left(\frac{x}{2 v A T^{\prime}}-\sqrt{\lambda} T^{\prime}\right)+e^{\left(\frac{\sqrt{\lambda} R x}{v A}\right)} \operatorname{erfc}\left(\frac{x}{2 v A T^{\prime}}+\sqrt{\lambda} T^{\prime}\right)\right] \\
& C(10,1)=\frac{1}{2}(0.065)\left[e^{-\frac{0.023 * 1 * 10}{353.16}}\right]\left[e ^ { ( - \frac { \sqrt { 0 . 0 2 3 } * 1 * 1 0 } { 3 5 3 . 1 6 * 0 . 0 1 2 7 } ) } \operatorname { e r f c } \left(\frac{10}{2 * 353.16 * 0.0127 * \sqrt{1-\frac{10}{353.16}}}\right.\right. \\
& \left.-\sqrt{0.023} * \sqrt{1-\frac{10}{353.16}}\right) \\
& +e^{\left(\frac{\sqrt{0.023} * 1 * 10}{353.16 * 0.0127}\right)} \operatorname{erfc}\left(\frac{10}{2 * 353.16 * 0.0127 * \sqrt{1-\frac{10}{353.16}}}+\sqrt{0.023}\right. \\
& \left.\left.* \sqrt{1-\frac{10}{353.16}}\right)\right] \\
& \left.+e^{(0.338)} \operatorname{erfc}(1.131+\sqrt{0.023} * 0.9857)\right]
\end{aligned}
$$




$$
\begin{gathered}
C(10,1)=0.0325\left[e^{-0.0006513}\right]\left[e^{(-0.338)} \operatorname{erfc}(0.9815)+e^{(0.338)} \operatorname{erfc}(1.28)\right] \\
C(10,1)=0.0325\left[e^{(-0.338)} * 0.1651+e^{(0.338)} * 0.07027\right] \\
C(10,1)=0.0325[0.1177+0.0985] \\
C(10,1)=0.00703 \frac{\mu g}{L}
\end{gathered}
$$


Outputs:

\begin{tabular}{|c|c|c|c|c|c|c|c|c|}
\hline $\begin{array}{c}\mathrm{C}(\mathrm{x}, \mathrm{t}) \\
(\mu \mathrm{g} / \mathrm{L})\end{array}$ & $\begin{array}{c}\mathrm{C} \\
(\mathrm{x}, 1 \mathrm{~d})\end{array}$ & $\begin{array}{c}\mathrm{C} \\
(\mathrm{x}, 5 \mathrm{~d})\end{array}$ & $\begin{array}{c}\mathrm{C} \\
(\mathrm{x}, 1 \mathrm{~d})\end{array}$ & $\begin{array}{c}\mathrm{C} \\
(\mathrm{x}, 18 \mathrm{~d})\end{array}$ & $\begin{array}{c}\mathrm{C} \\
(\mathrm{x}, 28 \mathrm{~d})\end{array}$ & $\begin{array}{c}\mathrm{C} \\
(\mathrm{x}, 35 \mathrm{~d})\end{array}$ & $\begin{array}{c}\mathrm{C} \\
(\mathrm{x}, 42 \mathrm{~d})\end{array}$ & $\begin{array}{c}\mathrm{C} \\
(\mathrm{x}, 65 \mathrm{~d})\end{array}$ \\
\hline $\begin{array}{c}\text { Concentration } \\
\text { at } 5 \mathrm{~m}\end{array}$ & $2.75 \mathrm{E}-02$ & $4.58 \mathrm{E}-02$ & $5.01 \mathrm{E}-02$ & $5.25 \mathrm{E}-02$ & $5.36 \mathrm{E}-02$ & $5.40 \mathrm{E}-02$ & $5.43 \mathrm{E}-02$ & $5.46 \mathrm{E}-02$ \\
\hline $\begin{array}{c}\text { Concentration } \\
\text { at } 10 \mathrm{~m}\end{array}$ & $7.02 \mathrm{E}-03$ & $2.97 \mathrm{E}-02$ & $3.73 \mathrm{E}-02$ & $4.17 \mathrm{E}-02$ & $4.39 \mathrm{E}-02$ & $4.47 \mathrm{E}-02$ & $4.52 \mathrm{E}-02$ & $4.59 \mathrm{E}-02$ \\
\hline $\begin{array}{c}\text { Concentration } \\
\text { at 30m }\end{array}$ & $0.00 \mathrm{E}+00$ & $1.96 \mathrm{E}-03$ & $7.44 \mathrm{E}-03$ & $1.36 \mathrm{E}-02$ & $1.78 \mathrm{E}-02$ & $1.94 \mathrm{E}-02$ & $2.06 \mathrm{E}-02$ & $2.24 \mathrm{E}-02$ \\
\hline $\begin{array}{c}\text { Concentration } \\
\text { at 50m }\end{array}$ & $0.00 \mathrm{E}+00$ & $2.05 \mathrm{E}-05$ & $6.51 \mathrm{E}-04$ & $3.00 \mathrm{E}-03$ & $5.81 \mathrm{E}-03$ & $7.28 \mathrm{E}-03$ & $8.39 \mathrm{E}-03$ & $1.04 \mathrm{E}-02$ \\
\hline $\begin{array}{c}\text { Concentration } \\
\text { at } 100 \mathrm{~m}\end{array}$ & $0.00 \mathrm{E}+00$ & $0.00 \mathrm{E}+00$ & $2.23 \mathrm{E}-08$ & $8.09 \mathrm{E}-06$ & $1.04 \mathrm{E}-04$ & $2.51 \mathrm{E}-04$ & $4.43 \mathrm{E}-04$ & $1.11 \mathrm{E}-03$ \\
\hline
\end{tabular}

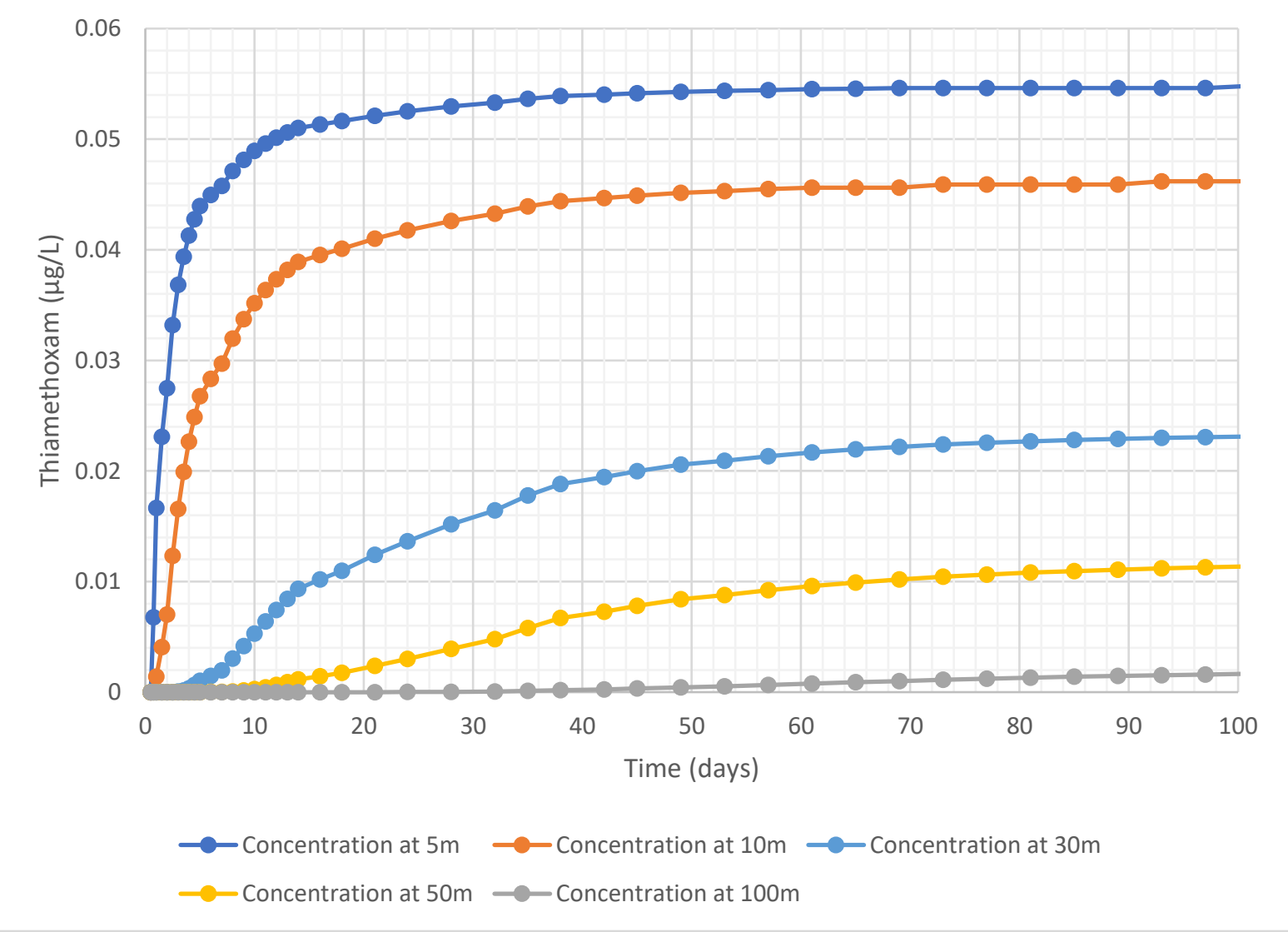




\begin{tabular}{|c|c|c|c|c|c|c|c|c|}
\hline $\begin{array}{c}\mathrm{C} / \mathrm{C}_{\mathrm{o}}(\mathrm{x}, \mathrm{t}) \\
(\mu \mathrm{g} / \mathrm{L})\end{array}$ & $\begin{array}{c}\mathrm{C} / \mathrm{C}_{\mathrm{o}} \\
(\mathrm{x}, 1 \mathrm{~d})\end{array}$ & $\begin{array}{c}\mathrm{C} / \mathrm{C}_{\mathrm{o}} \\
(\mathrm{x}, 5 \mathrm{~d})\end{array}$ & $\begin{array}{c}\mathrm{C} / \mathrm{C}_{\mathrm{o}} \\
(\mathrm{x}, 10 \mathrm{~d})\end{array}$ & $\begin{array}{c}\mathrm{C} / \mathrm{C}_{\mathrm{o}} \\
(\mathrm{x}, 18 \mathrm{~d})\end{array}$ & $\begin{array}{c}\mathrm{C} / \mathrm{C}_{\mathrm{o}} \\
(\mathrm{x}, 28 \mathrm{~d})\end{array}$ & $\begin{array}{c}\mathrm{C} / \mathrm{C}_{\mathrm{o}} \\
(\mathrm{x}, 35 \mathrm{~d})\end{array}$ & $\begin{array}{c}\mathrm{C} / \mathrm{C}_{\mathrm{o}} \\
(\mathrm{x}, 42 \mathrm{~d})\end{array}$ & $\begin{array}{c}\mathrm{C} / \mathrm{C}_{\mathrm{o}} \\
(\mathrm{x}, 65 \mathrm{~d})\end{array}$ \\
\hline $\begin{array}{c}\text { Concentration } \\
\text { at 5m }\end{array}$ & $4.23 \mathrm{E}-01$ & $7.04 \mathrm{E}-01$ & $7.71 \mathrm{E}-01$ & $8.08 \mathrm{E}-01$ & $8.25 \mathrm{E}-01$ & $8.31 \mathrm{E}-01$ & $8.35 \mathrm{E}-01$ & $8.40 \mathrm{E}-01$ \\
\hline $\begin{array}{c}\text { Concentration } \\
\text { at 10m }\end{array}$ & $1.08 \mathrm{E}-01$ & $4.57 \mathrm{E}-01$ & $5.74 \mathrm{E}-01$ & $6.42 \mathrm{E}-01$ & $6.76 \mathrm{E}-01$ & $6.87 \mathrm{E}-01$ & $6.95 \mathrm{E}-01$ & $7.06 \mathrm{E}-01$ \\
\hline $\begin{array}{c}\text { Concentration } \\
\text { at 30m }\end{array}$ & $0.00 \mathrm{E}+00$ & $3.01 \mathrm{E}-02$ & $1.14 \mathrm{E}-01$ & $2.10 \mathrm{E}-01$ & $2.74 \mathrm{E}-01$ & $2.99 \mathrm{E}-01$ & $3.16 \mathrm{E}-01$ & $3.44 \mathrm{E}-01$ \\
\hline $\begin{array}{c}\text { Concentration } \\
\text { at 50m }\end{array}$ & $0.00 \mathrm{E}+00$ & $3.15 \mathrm{E}-04$ & $1.00 \mathrm{E}-02$ & $4.61 \mathrm{E}-02$ & $8.93 \mathrm{E}-02$ & $1.12 \mathrm{E}-01$ & $1.29 \mathrm{E}-01$ & $1.60 \mathrm{E}-01$ \\
\hline $\begin{array}{c}\text { Concentration } \\
\text { at 100m }\end{array}$ & $0.00 \mathrm{E}+00$ & $0.00 \mathrm{E}+00$ & $3.42 \mathrm{E}-07$ & $1.24 \mathrm{E}-04$ & $1.59 \mathrm{E}-03$ & $3.86 \mathrm{E}-03$ & $6.82 \mathrm{E}-03$ & $1.71 \mathrm{E}-02$ \\
\hline
\end{tabular}

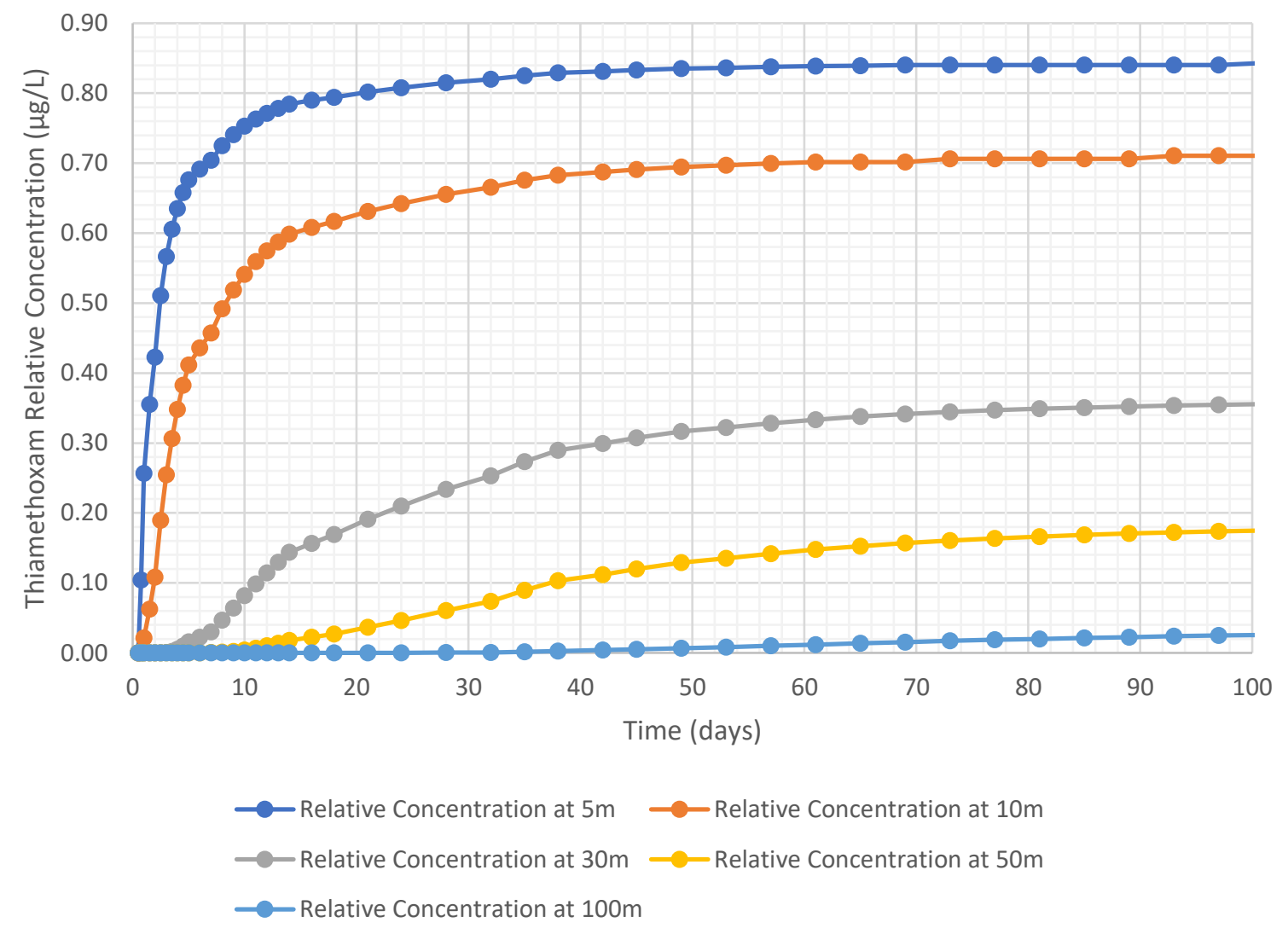




\section{Appendix F - Soil Sampling Locations}




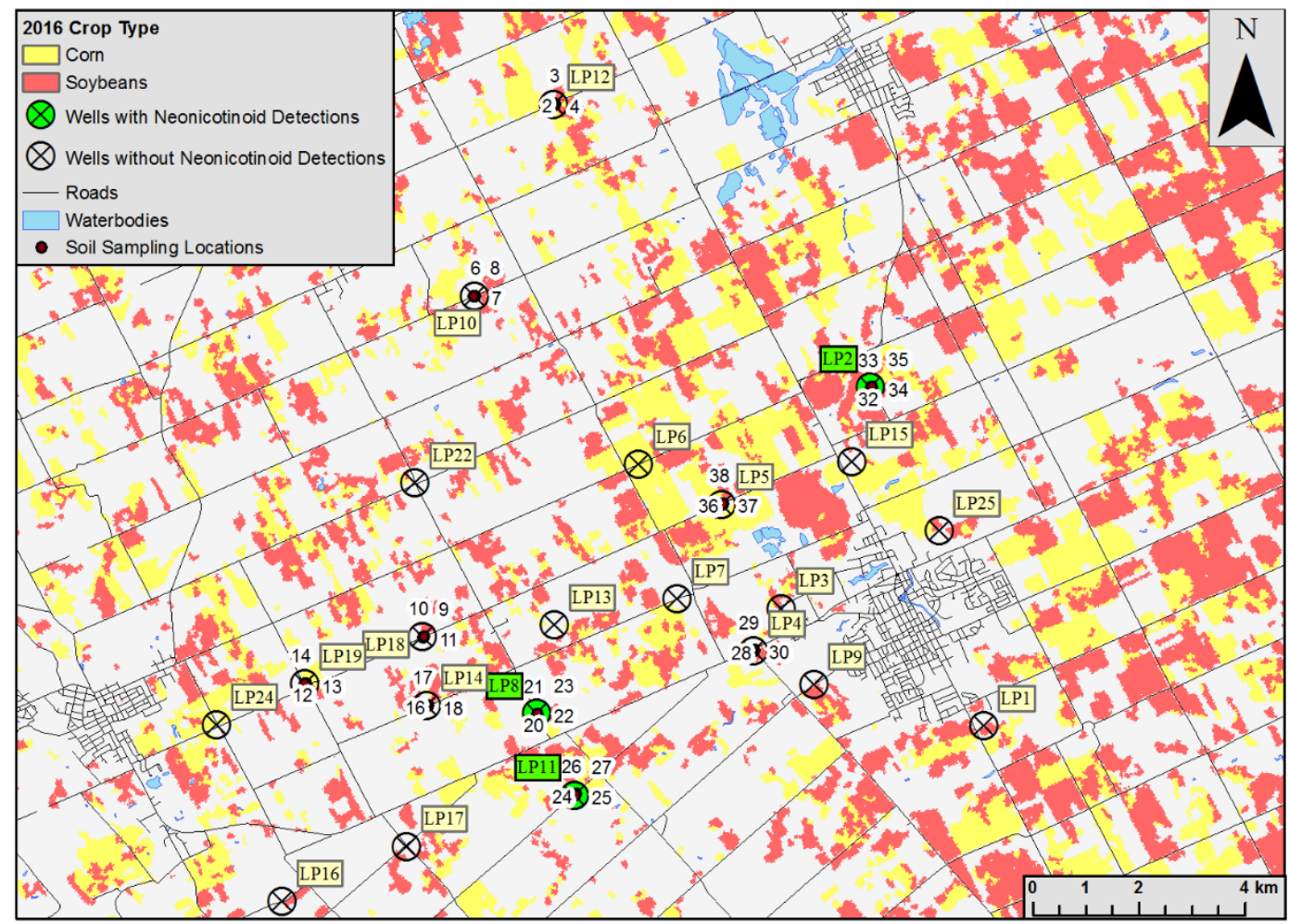

Soil sampling locations from July 2016 for Norfolk County. Several soil samples are missing from the map. These include point 1 (LP12), 5 (LP10), 15 (LP19), 31 (LP4), and 39 (LP5).

\begin{tabular}{|c|c|c|c|}
\hline $\begin{array}{l}\text { Long Point } \\
\text { Monitoring } \\
\text { Well ID }\end{array}$ & Soil Sample & Latitude $(\mathrm{dd})$ & Longitude (dd) \\
\hline \multirow{4}{*}{ LP-MW-12 } & 1 & 42.9368 & -80.3621 \\
\hline & 2 & 42.9369 & -80.3619 \\
\hline & 3 & 42.9370 & -80.3618 \\
\hline & 4 & 42.9369 & -80.3621 \\
\hline \multirow{4}{*}{ LP-MW-10 } & 5 & 42.9369 & -80.3621 \\
\hline & 6 & 42.9077 & -80.3889 \\
\hline & 7 & 42.9077 & -80.3889 \\
\hline & 8 & 42.9077 & -80.3893 \\
\hline \multirow{3}{*}{ LP-MW-18 } & 9 & 42.8526 & -80.4171 \\
\hline & 10 & 42.8527 & -80.4169 \\
\hline & 11 & 42.8526 & -80.4168 \\
\hline \multirow{4}{*}{ LP-MW-19 } & 12 & 42.8490 & -80.4458 \\
\hline & 13 & 42.8490 & -80.4456 \\
\hline & 14 & 42.8490 & -80.4458 \\
\hline & 15 & 42.8489 & -80.4459 \\
\hline \multirow{2}{*}{ LP-MW-14 } & 16 & 42.8410 & -80.4191 \\
\hline & 17 & 42.8410 & -80.4193 \\
\hline
\end{tabular}




\begin{tabular}{|c|c|c|c|} 
& 18 & 42.8409 & -80.4195 \\
\cline { 2 - 4 } & 19 & 42.8410 & -80.4195 \\
\hline \multirow{4}{*}{ LP-MW-08 } & 20 & 42.8358 & -80.3949 \\
\cline { 2 - 4 } & 21 & 42.8357 & -80.3948 \\
\cline { 2 - 4 } & 22 & 42.8357 & -80.3948 \\
\hline \multirow{4}{*}{ LP-MW-11 } & 23 & 42.8358 & -80.3949 \\
\cline { 2 - 4 } & 24 & 42.8209 & -80.3902 \\
\cline { 2 - 4 } & 25 & 42.8209 & -80.3902 \\
\cline { 2 - 4 } & 26 & 42.8210 & -80.3901 \\
\hline & 27 & 42.8208 & -80.3902 \\
\cline { 2 - 4 } & 28 & 42.8385 & -80.3429 \\
\cline { 2 - 4 } & 29 & 42.8387 & -80.3429 \\
\cline { 2 - 4 } & 30 & 42.8388 & -80.3432 \\
\hline \multirow{4}{*}{ LP-MW-02 } & 31 & 42.8388 & -80.3434 \\
\cline { 2 - 4 } & 32 & 42.8785 & -80.3041 \\
\cline { 2 - 4 } & 33 & 42.8783 & -80.3040 \\
\cline { 2 - 4 } LP-MW-05 & 34 & 42.8783 & -80.3039 \\
\cline { 2 - 4 } & 35 & 42.8784 & -80.3039 \\
\cline { 2 - 4 } & 36 & 42.8642 & -80.3433 \\
\cline { 2 - 4 } & 37 & 42.8642 & -80.3433 \\
\hline & 38 & 42.8643 & -80.3430 \\
\hline
\end{tabular}




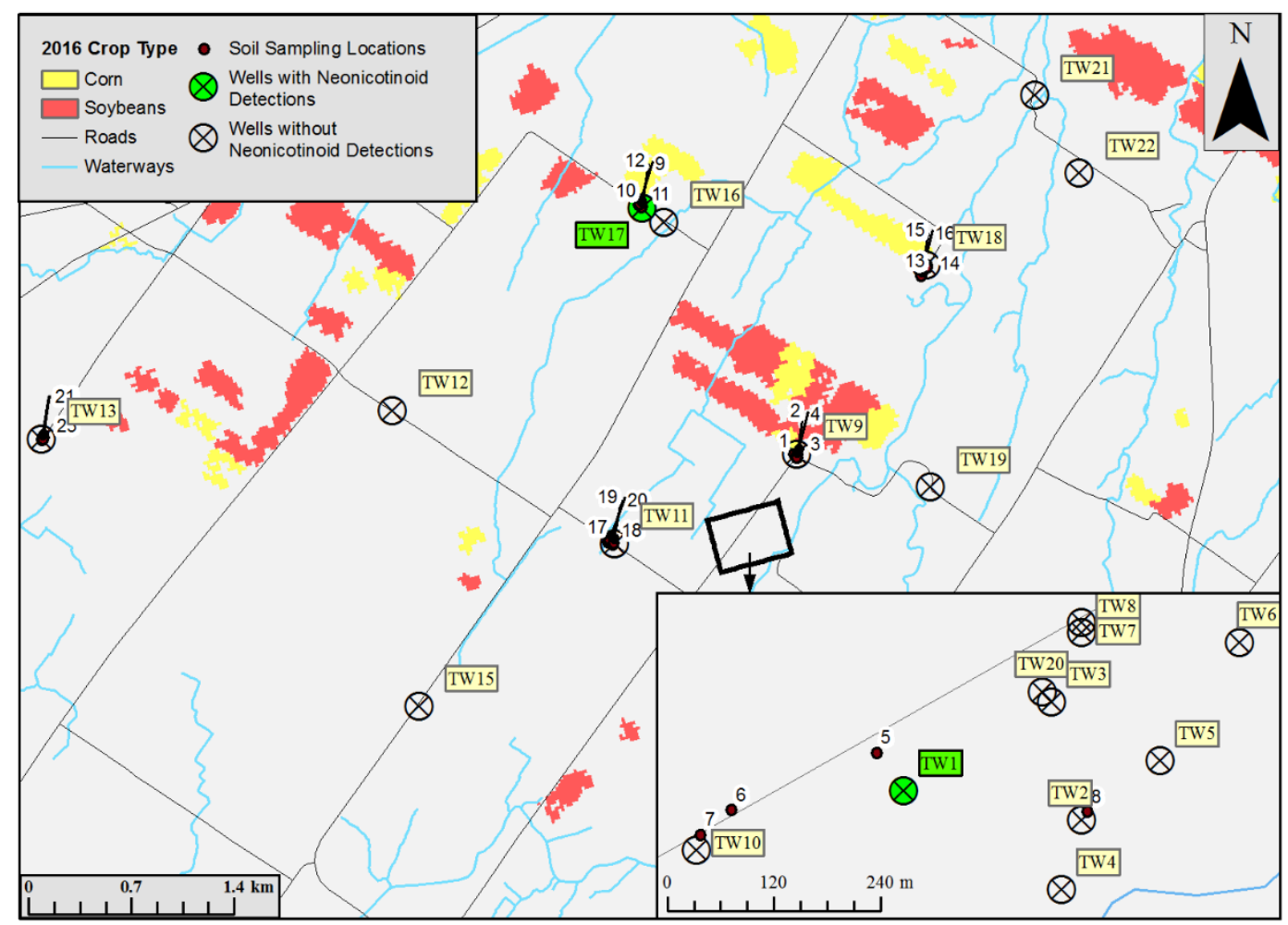

Soil sampling locations from July 2016 for Lanark County. Points 21, 22, 23, and 24 were taken near TW13.

\begin{tabular}{|c|c|c|c|}
\hline $\begin{array}{c}\text { Tay } \\
\text { Well ID }\end{array}$ & Soil Sample & Latitude (dd) & Longitude (dd) \\
\hline \multirow{4}{*}{ TW9 } & 1 & 44.8443 & -76.3427 \\
\hline & 2 & 44.8442 & -76.3424 \\
\hline & 3 & 44.8440 & -76.3425 \\
\hline & 4 & 44.8440 & -76.3426 \\
\hline \multirow{4}{*}{$\begin{array}{l}\text { Hay } \\
\text { Field }\end{array}$} & 5 & 44.8401 & -76.3492 \\
\hline & 6 & 44.8395 & -76.3507 \\
\hline & 7 & 44.8393 & -76.3510 \\
\hline & 8 & 44.8395 & -76.3471 \\
\hline \multirow{4}{*}{ TW17 } & 9 & 44.8613 & -76.3499 \\
\hline & 10 & 44.8613 & -76.3499 \\
\hline & 11 & 44.8615 & -76.3501 \\
\hline & 12 & 44.8615 & -76.3500 \\
\hline \multirow{4}{*}{ TW18 } & 13 & 44.8533 & -76.3274 \\
\hline & 14 & 44.8532 & -76.3275 \\
\hline & 15 & 44.8529 & -76.3280 \\
\hline & 16 & 44.8527 & -76.3281 \\
\hline \multirow{4}{*}{ TW11 } & 17 & 44.8418 & -76.3598 \\
\hline & 18 & 44.8420 & -76.3601 \\
\hline & 19 & 44.8421 & -76.3600 \\
\hline & 20 & 44.8418 & -76.3597 \\
\hline
\end{tabular}




\begin{tabular}{|c|c|c|c|}
\multirow{4}{*}{ TW13 } & 21 & 44.8570 & -76.4050 \\
\cline { 2 - 4 } & 22 & 44.8571 & -76.4050 \\
\cline { 2 - 4 } & 23 & 44.8572 & -76.4048 \\
\cline { 2 - 4 } & 24 & 44.8571 & -76.4049 \\
\hline
\end{tabular}


Appendix G - Lab Analysis Information 
Limits of detection, quantification, percentage of recovery and optimized mass spectrometry parameters used for the LC-ESI(+)-MS/MS analysis of 11 pesticides in water with their relevant deuterium internal standard.

\begin{tabular}{|c|c|c|c|c|c|c|c|c|c|c|}
\hline Analyte & $\begin{array}{c}\mathrm{R}_{\mathrm{t}}^{\mathrm{A}} \\
(\min )\end{array}$ & $\begin{array}{c}\text { Precusor ion } \\
(\mathrm{m} / \mathrm{z})\end{array}$ & $\begin{array}{l}\text { Product ions }{ }^{B} \\
(m / z)\end{array}$ & $\begin{array}{l}\mathrm{DP}^{\mathrm{C}} \\
(\mathrm{V})\end{array}$ & $\begin{array}{l}\mathrm{FPD}^{\mathrm{D}} \\
(\mathrm{V})\end{array}$ & $\begin{array}{l}\mathrm{CE}^{\mathrm{E}} \\
(\mathrm{V})\end{array}$ & $\begin{array}{l}\mathrm{CXPF}^{\mathrm{F}} \\
(\mathrm{V})\end{array}$ & $\begin{array}{l}\mathrm{LOD} \pm S D^{G} \\
\left(\mathrm{ng} \mathrm{mL} \mathbf{m}^{-1}\right)\end{array}$ & $\begin{array}{c}\mathrm{LOQ} \pm \mathrm{SD}^{\mathrm{H}} \\
(\mathrm{ng} \mathrm{mL}-1) \\
\end{array}$ & $\begin{array}{c}\% \mathrm{R} \pm \mathrm{SD} \\
(\%)\end{array}$ \\
\hline Acetamiprid & 10.3 & $222.9[\mathrm{M}+\mathrm{H}]+$ & $126 / 56$ & 36 & 20 & $27 / 25$ & $13 / 13$ & $0.008 \pm 0.001$ & $0.025 \pm 0.003$ & $96.3 \pm 7.2$ \\
\hline Clothianidin & 10 & $250[\mathrm{M}+\mathrm{H}]+$ & $169 / 132$ & 20 & 25 & $18 / 18$ & $15 / 15$ & $0.043 \pm 0.006$ & $0.114 \pm 0.017$ & $91.7 \pm 4.4$ \\
\hline Dinotefuran & 6.7 & $202.8[\mathrm{M}+\mathrm{H}]+$ & $114 / 87$ & 14 & 22 & $18 / 23$ & $11 / 9$ & $0.009 \pm 0.012$ & $0.025 \pm 0.035$ & $77.6 \pm 3.5$ \\
\hline Imidacloprid & 9.4 & $256[\mathrm{M}+\mathrm{H}]+$ & $209 / 175$ & 30 & 30 & $23 / 27$ & $17 / 18$ & $0.025 \pm 0.012$ & $0.076 \pm 0.034$ & $78.9 \pm 0.6$ \\
\hline Thiacloprid & 11.4 & $253[\mathrm{M}+\mathrm{H}]+$ & $126 / 99$ & 33.9 & 31 & $31 / 20$ & $15 / 20$ & $0.012 \pm 0.041$ & $0.032 \pm 0.128$ & $77.1 \pm 3.0$ \\
\hline Thiamethoxan & 8 & $291.9[\mathrm{M}+\mathrm{H}]+$ & 211/181 & 19 & 16 & $18 / 31$ & $20 / 18$ & $0.012 \pm 0.001$ & $0.038 \pm 0.003$ & $92.6 \pm 3.1$ \\
\hline Cyantraniliprole & 14 & $475.2[\mathrm{M}+\mathrm{H}]+$ & $286 / 444$ & 21 & 32 & $22 / 28$ & $28 / 35$ & $0.005 \pm 0.003$ & $0.016 \pm 0.008$ & $65 \pm 2.4$ \\
\hline Atrazine & 15.1 & $216[\mathrm{M}+\mathrm{H}]+$ & $174 / 96$ & 40 & 30 & $25 / 33$ & $18 / 18$ & $0.004 \pm 0.002$ & $0.013 \pm 0.005$ & $115.4 \pm 11.9$ \\
\hline Metalochlor & 17.3 & $284[\mathrm{M}+\mathrm{H}]+$ & $252 / 176$ & 19 & 20 & $22 / 37$ & $39 / 30$ & $0.015 \pm 0.006$ & $0.033 \pm 0.013$ & $73.3 \pm 1.1$ \\
\hline Azoxyatrobin & 15.6 & $404.3[\mathrm{M}+\mathrm{H}]+$ & $372 / 344$ & 30 & 25 & $22 / 34$ & $29 / 25$ & $0.007 \pm 0.001$ & $0.017 \pm 0.004$ & $71 \pm 9.3$ \\
\hline $\begin{array}{c}\text { Mefenoxam } \\
\text { Internal Standards }\end{array}$ & 14.7 & $280.1[\mathrm{M}+\mathrm{H}]+$ & 220/192 & 19 & 28 & $20 / 25$ & $15 / 28$ & $0.003 \pm 0.002$ & $0.008 \pm 0.004$ & $86 \pm 8.2$ \\
\hline Acetamiprid-d3 & 10.3 & $226[\mathrm{M}+\mathrm{H}]+$ & $126 / 59.2$ & 40 & 32 & $26 / 35$ & $16 / 15$ & & & \\
\hline Atrazine-d5 & 15.1 & $221[\mathrm{M}+\mathrm{H}]+$ & 179.2/101.1 & 40 & 32 & $26 / 35$ & $16 / 15$ & & & \\
\hline Clothianidin-d3 & 10 & $253.1[\mathrm{M}+\mathrm{H}]+$ & 172.1/131.9 & 20 & 20.5 & $19.3 / 22$ & $18 / 18$ & & & \\
\hline Imidacloprid-d4 & 9.4 & $260[\mathrm{M}+\mathrm{H}]+$ & 213.1/179.3 & 21 & 29 & $25 / 25$ & $23 / 23$ & & & \\
\hline Metalochlor-d4 & 17.3 & $290.1[\mathrm{M}+\mathrm{H}]+$ & 258.3/182.2 & 25.7 & 7 & $22 / 35$ & $24.5 / 16$ & & & \\
\hline Thiamethoxan-d3 & 8 & $295[\mathrm{M}+\mathrm{H}]+$ & 214/184 & 15.2 & 25.2 & $18.8 / 31.5$ & & $.1 / 22.5$ & & \\
\hline
\end{tabular}


Appendix $\mathrm{H}$ - Field Parameters and Lab Analysis Graphs 

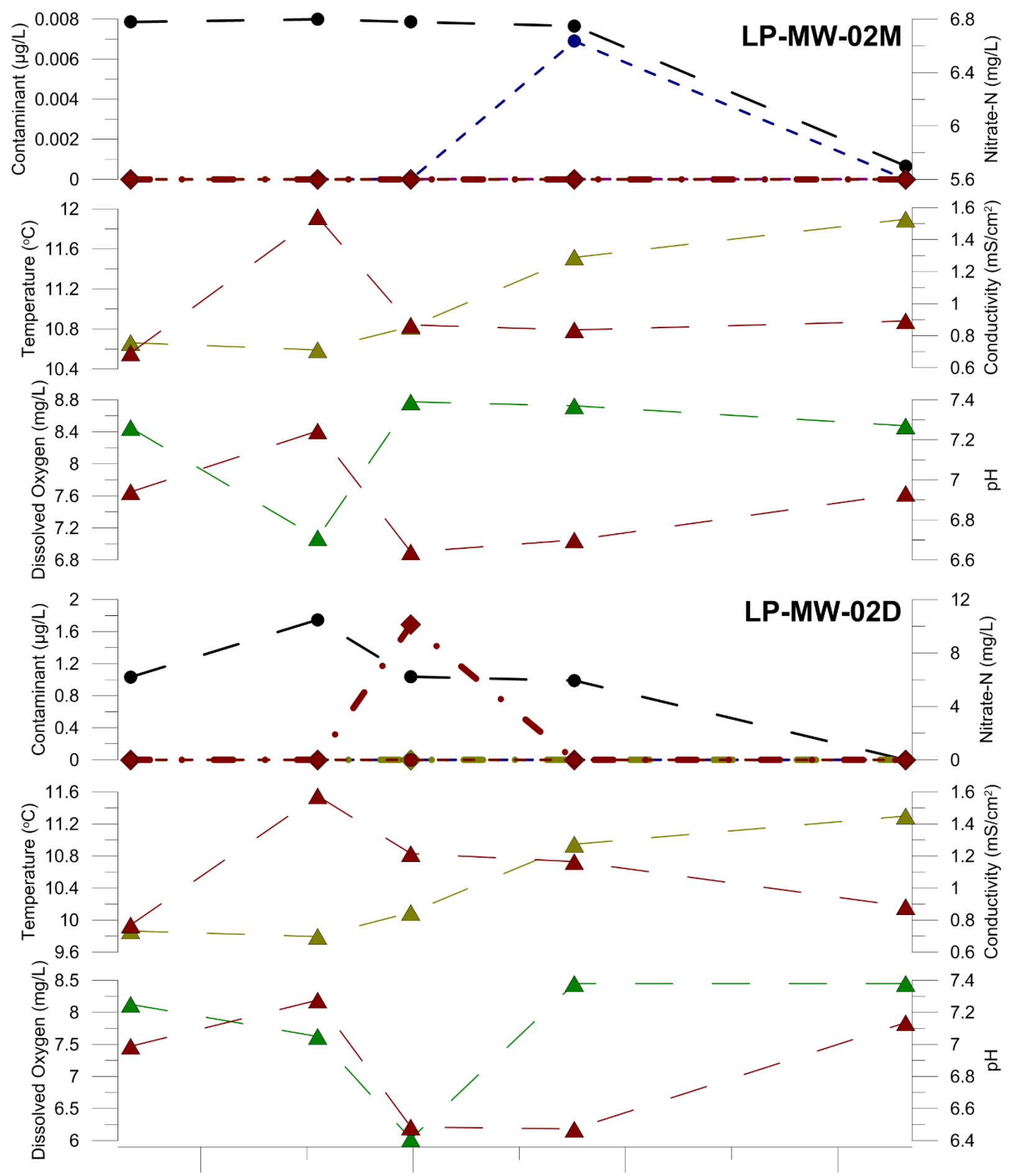

May 10, $2016 \quad$ Aug 18, $2016 \quad$ Nov 26, $2016 \quad$ Mar 06, 2017

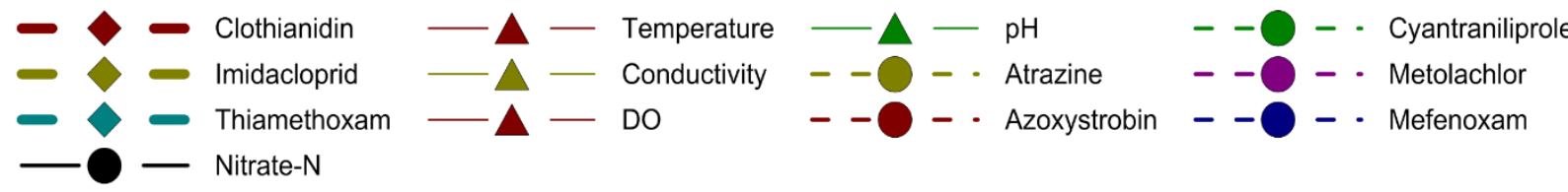



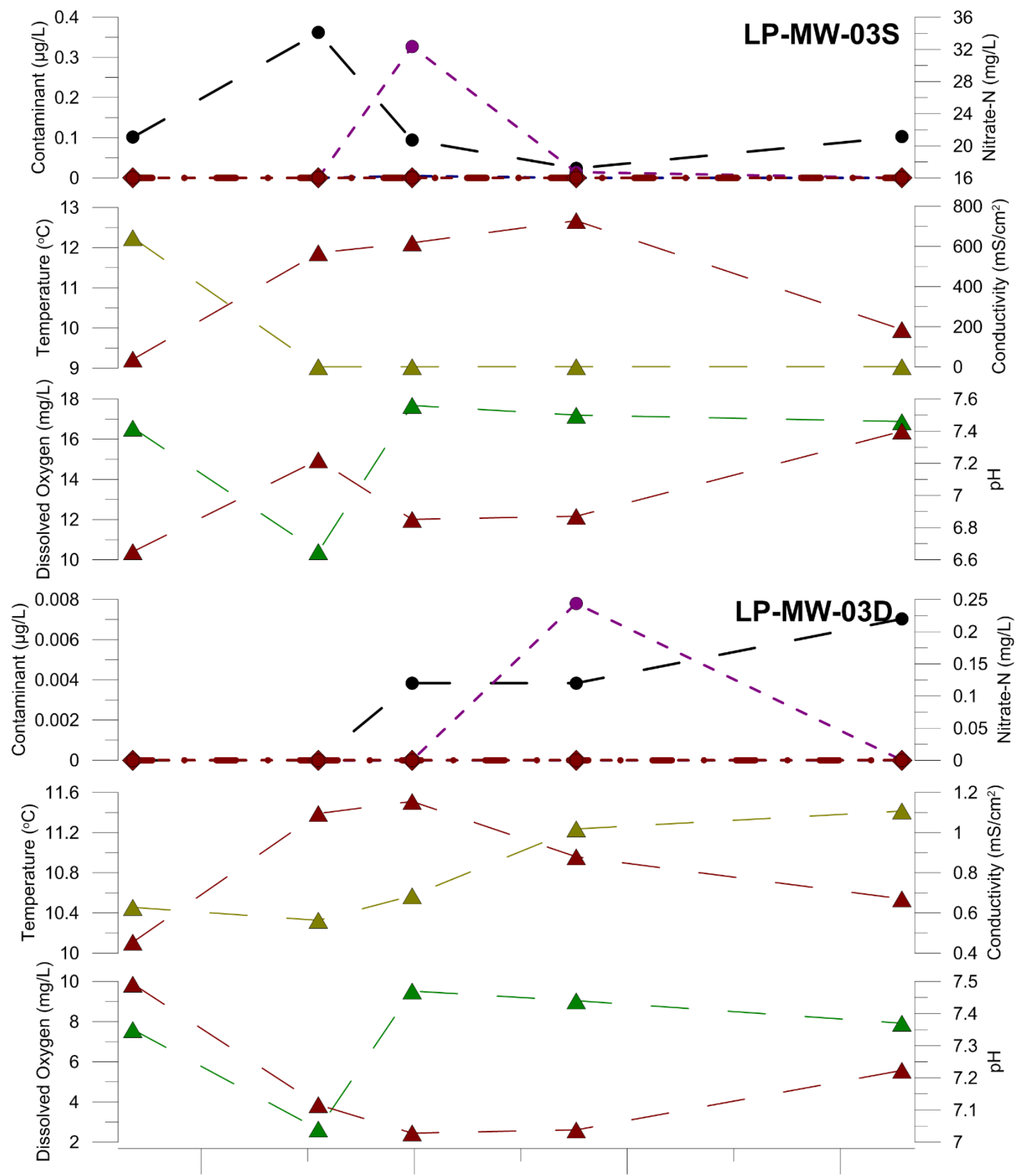

May 10, 2016

Aug 18, 2016

Nov 26, 2016

Mar 06, 2017

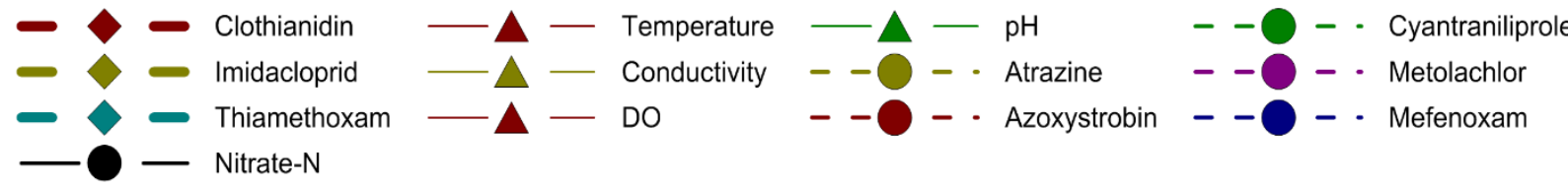



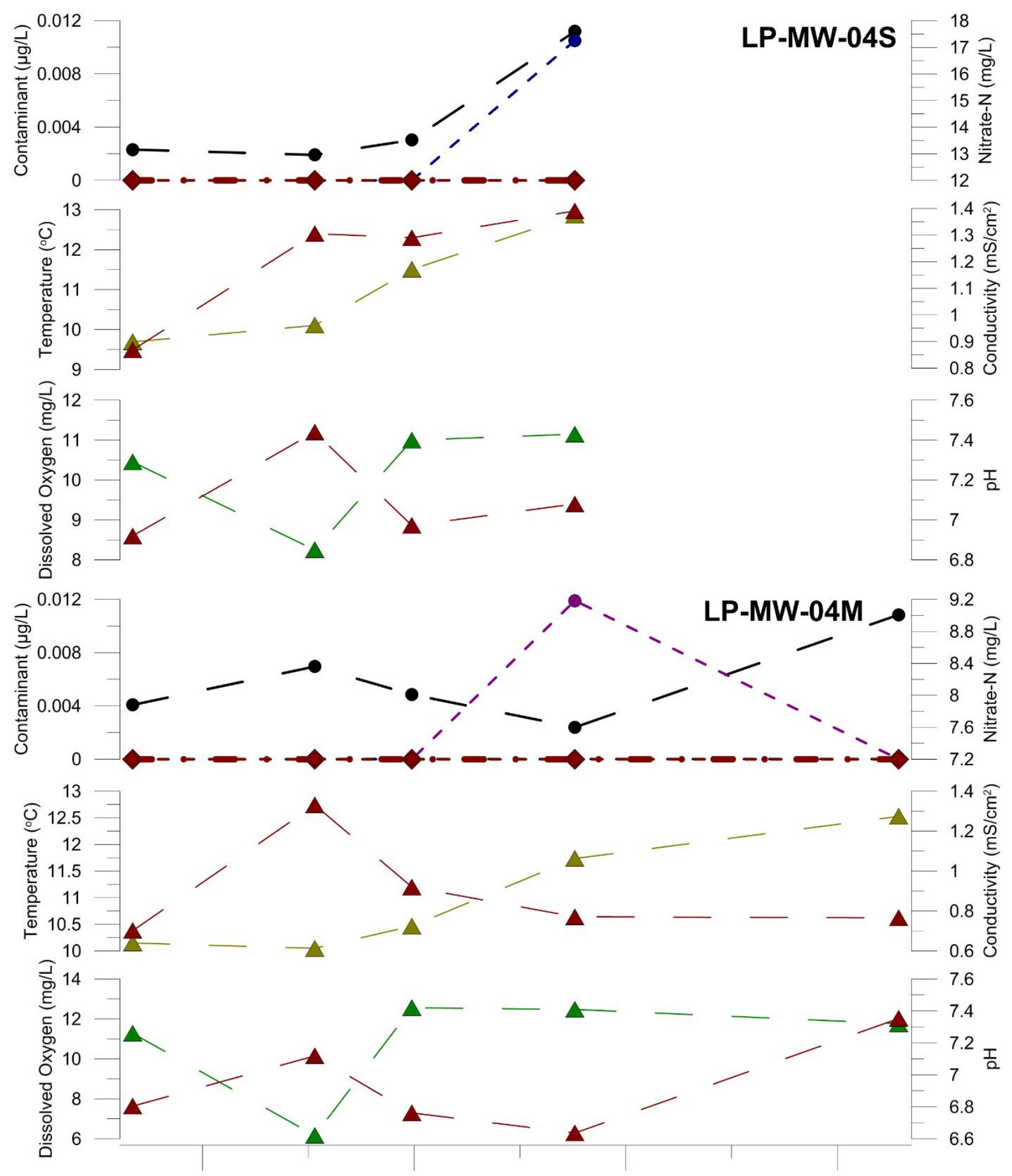

May 10, $2016 \quad$ Aug 18, 2016 Nov 26, $2016 \quad$ Mar 06, 2017

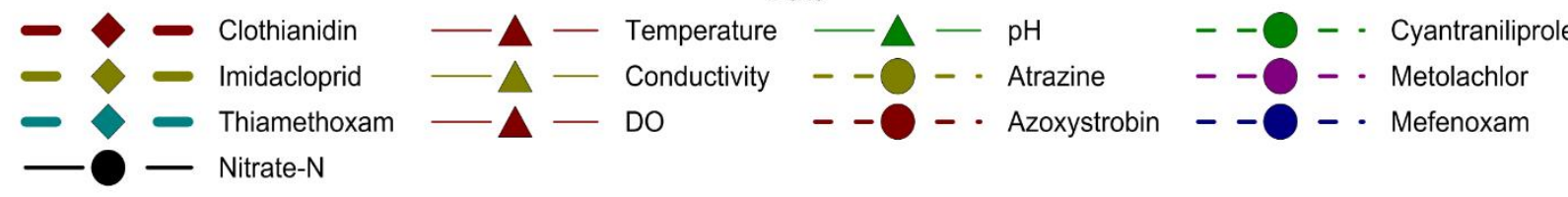



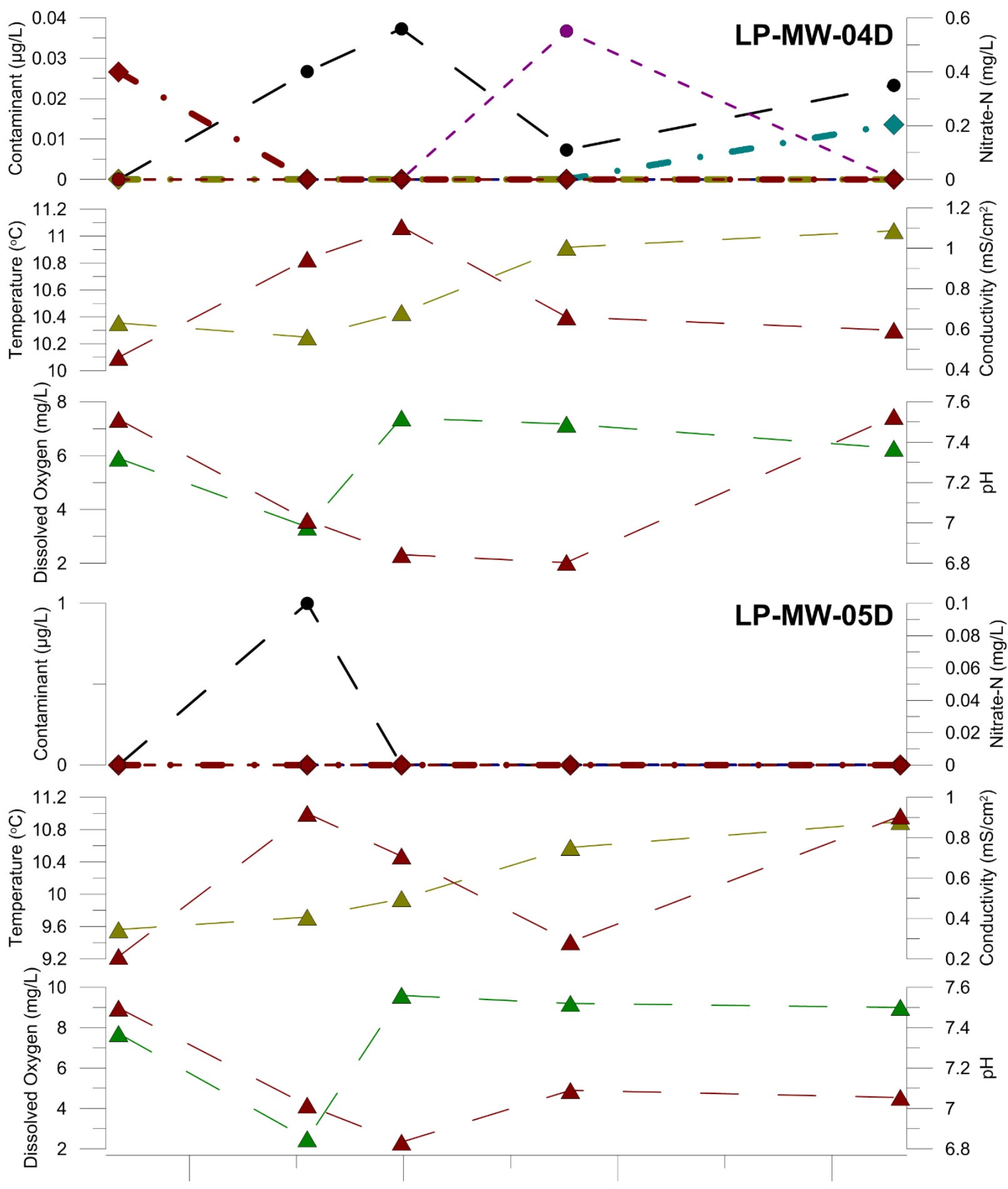

May 10, $2016 \quad$ Aug 18, $2016 \quad$ Nov 26, $2016 \quad$ Mar 06, 2017

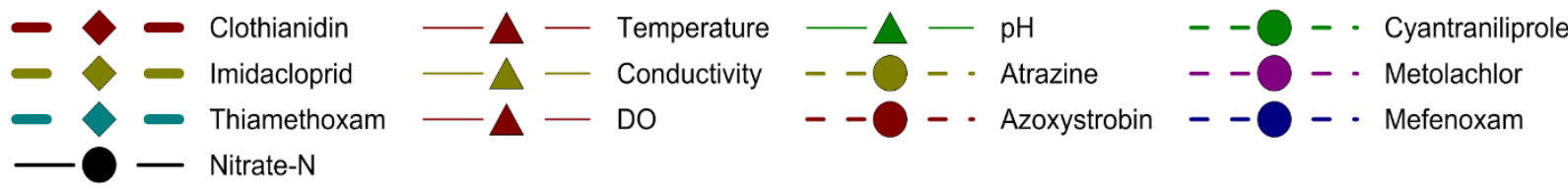



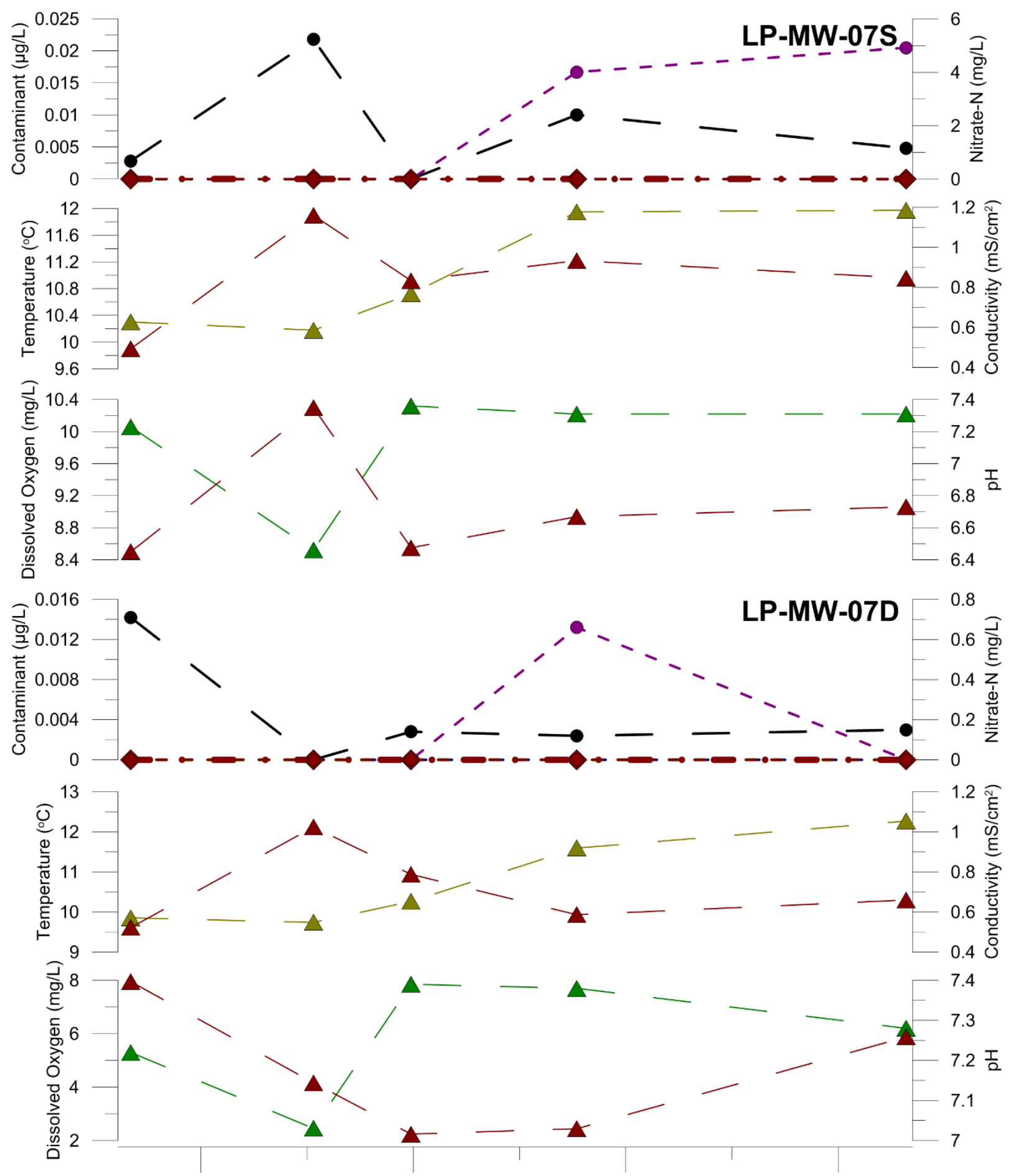

May 10, 2016

Aug 18, 2016 Date Nov 26, 2016

Mar 06, 2017

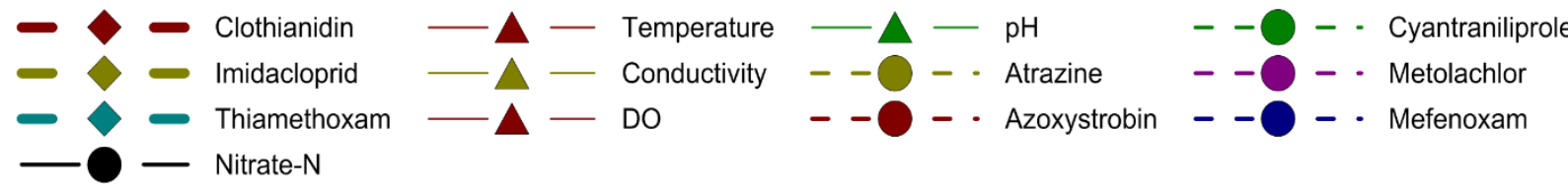



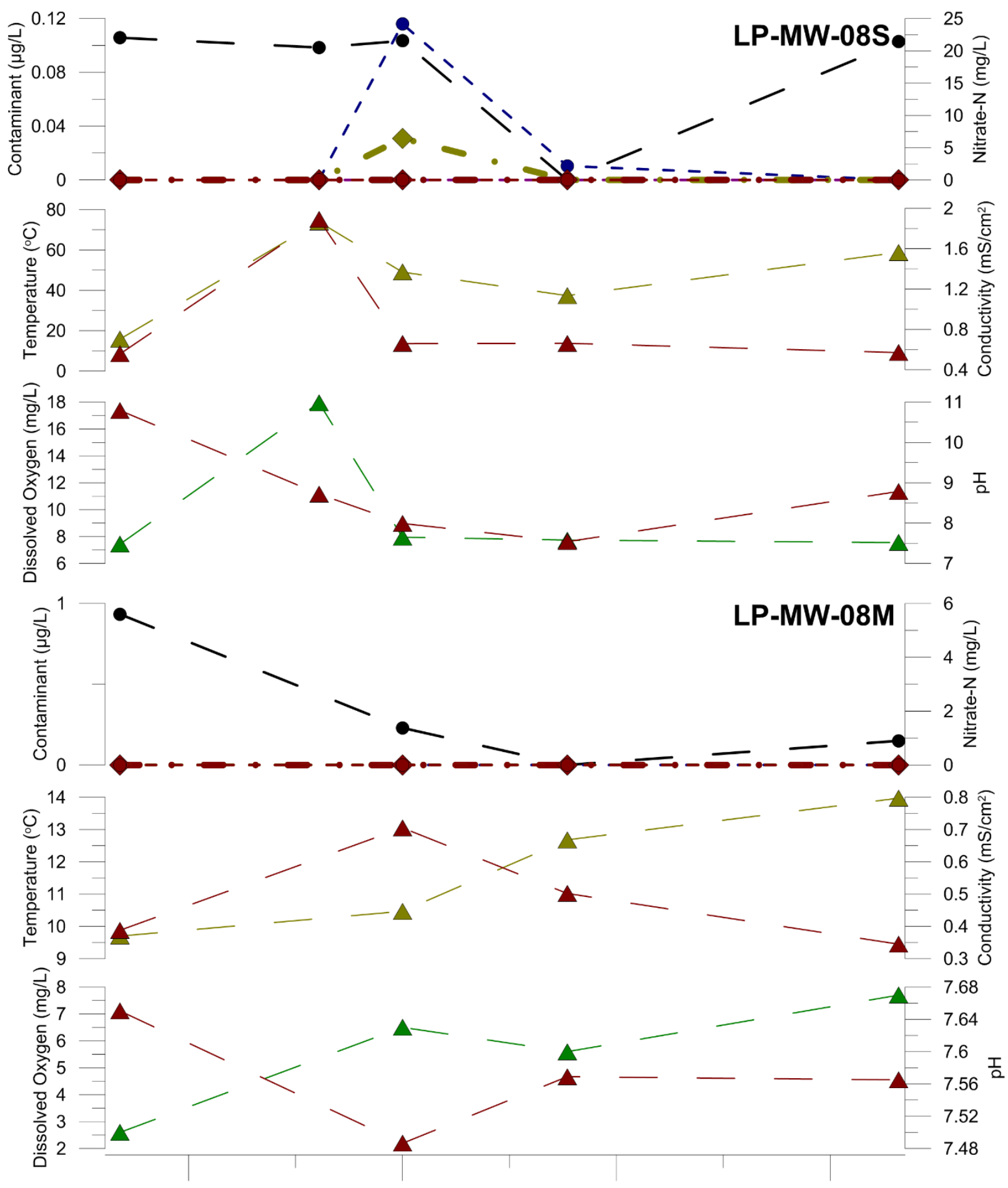

May 10, $2016 \quad$ Aug 18, $2016 \quad$ Nov 26, $2016 \quad$ Mar 06, 2017

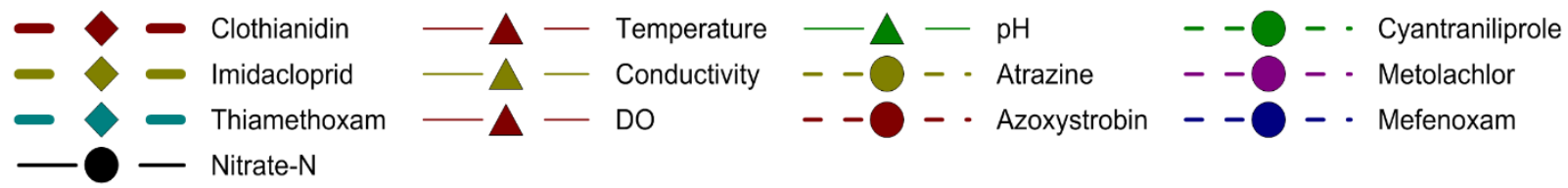



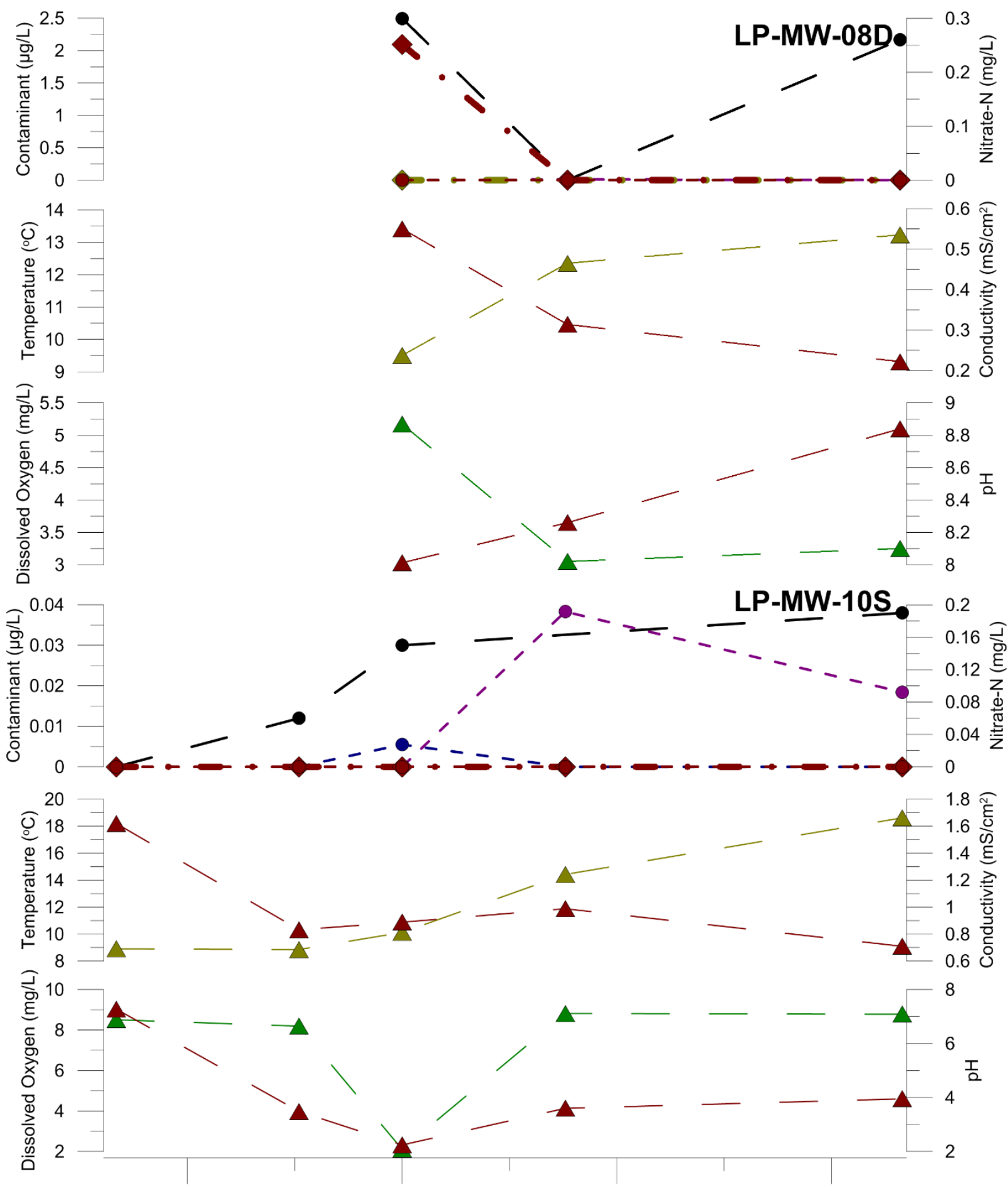

May 10, $2016 \quad$ Aug 18, $2016 \quad$ Nov 26, $2016 \quad$ Mar 06, 2017

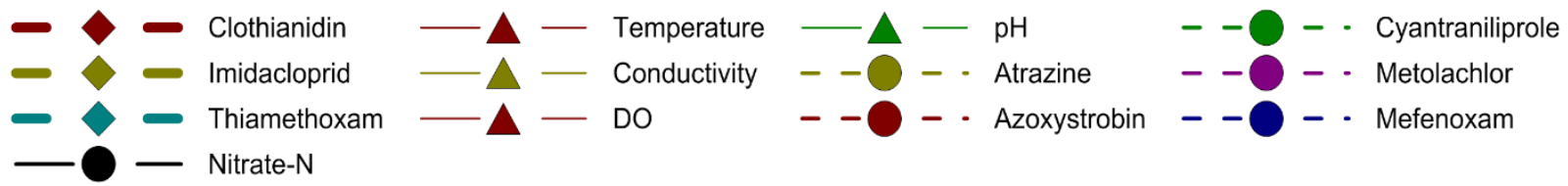





4

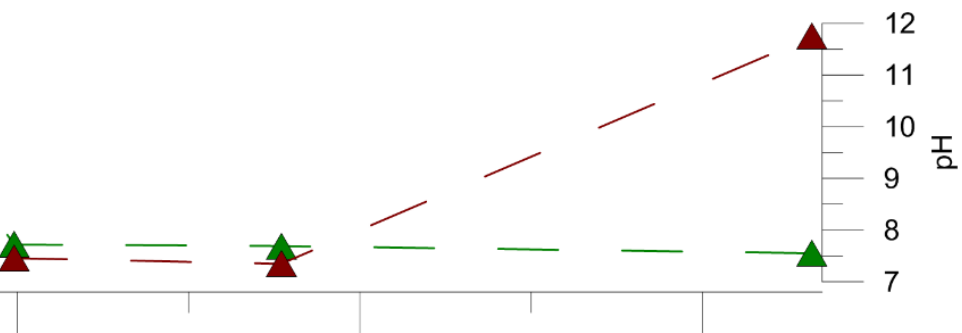

May 10, 2016

Aug 18, 2016

Nov 26, 2016

Mar 06, 2017

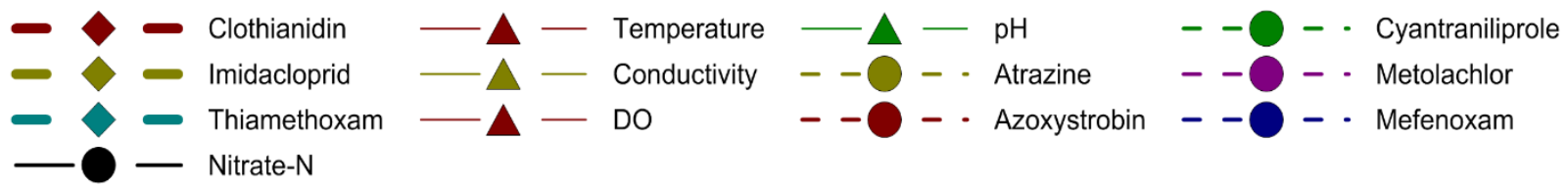



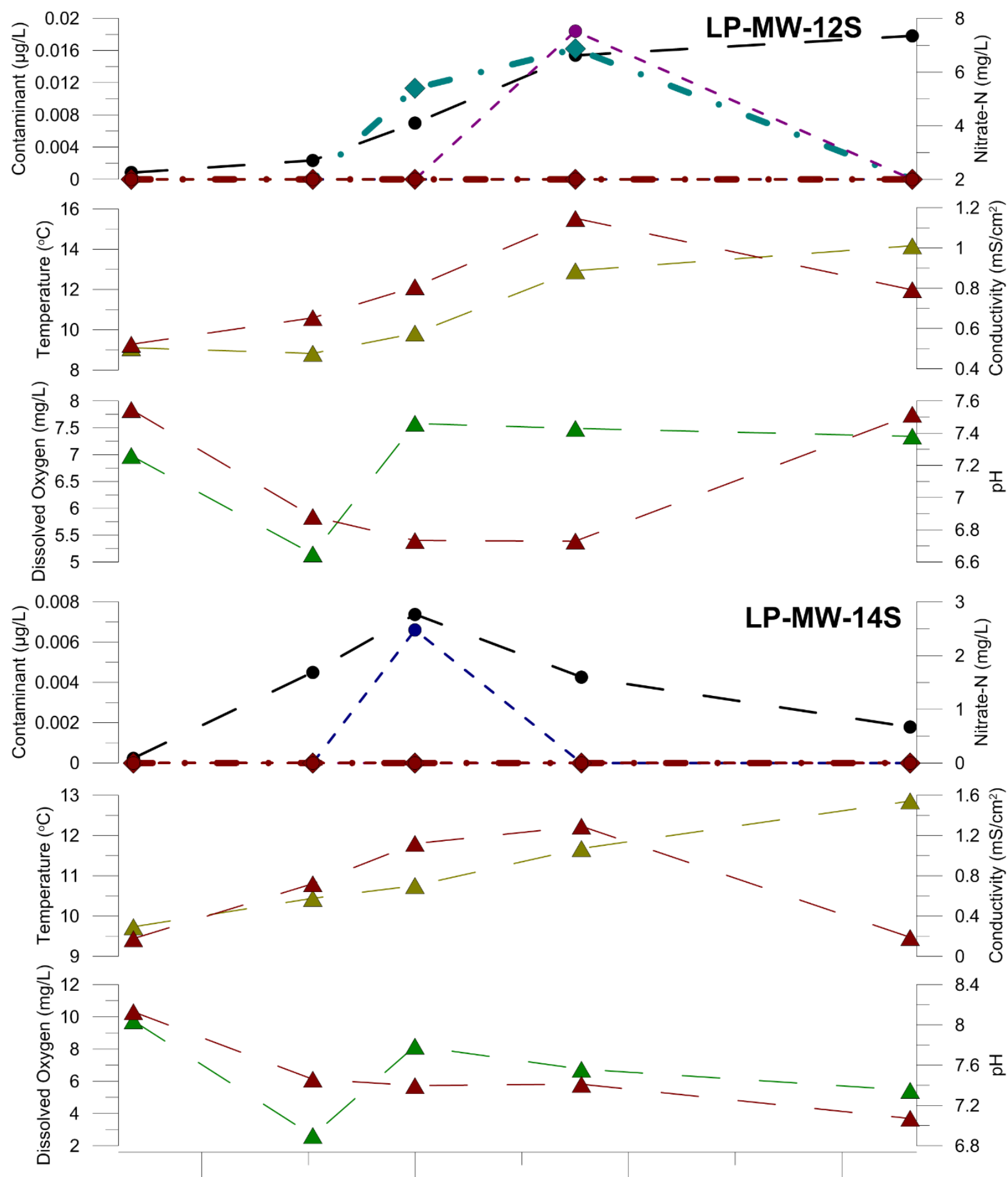

May 10, 2016

Aug 18, 2016

Nov 26, 2016

Mar 06, 2017

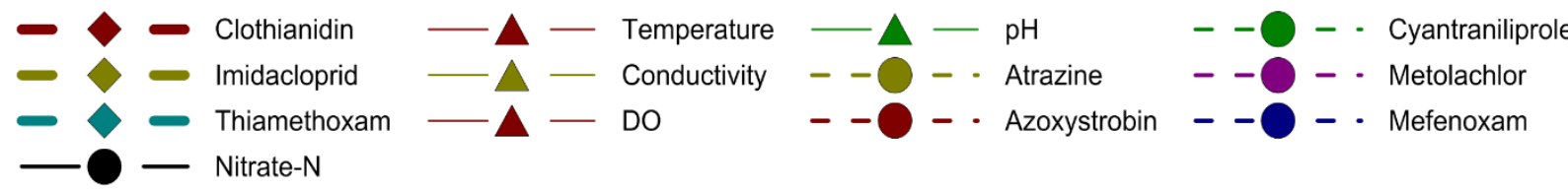



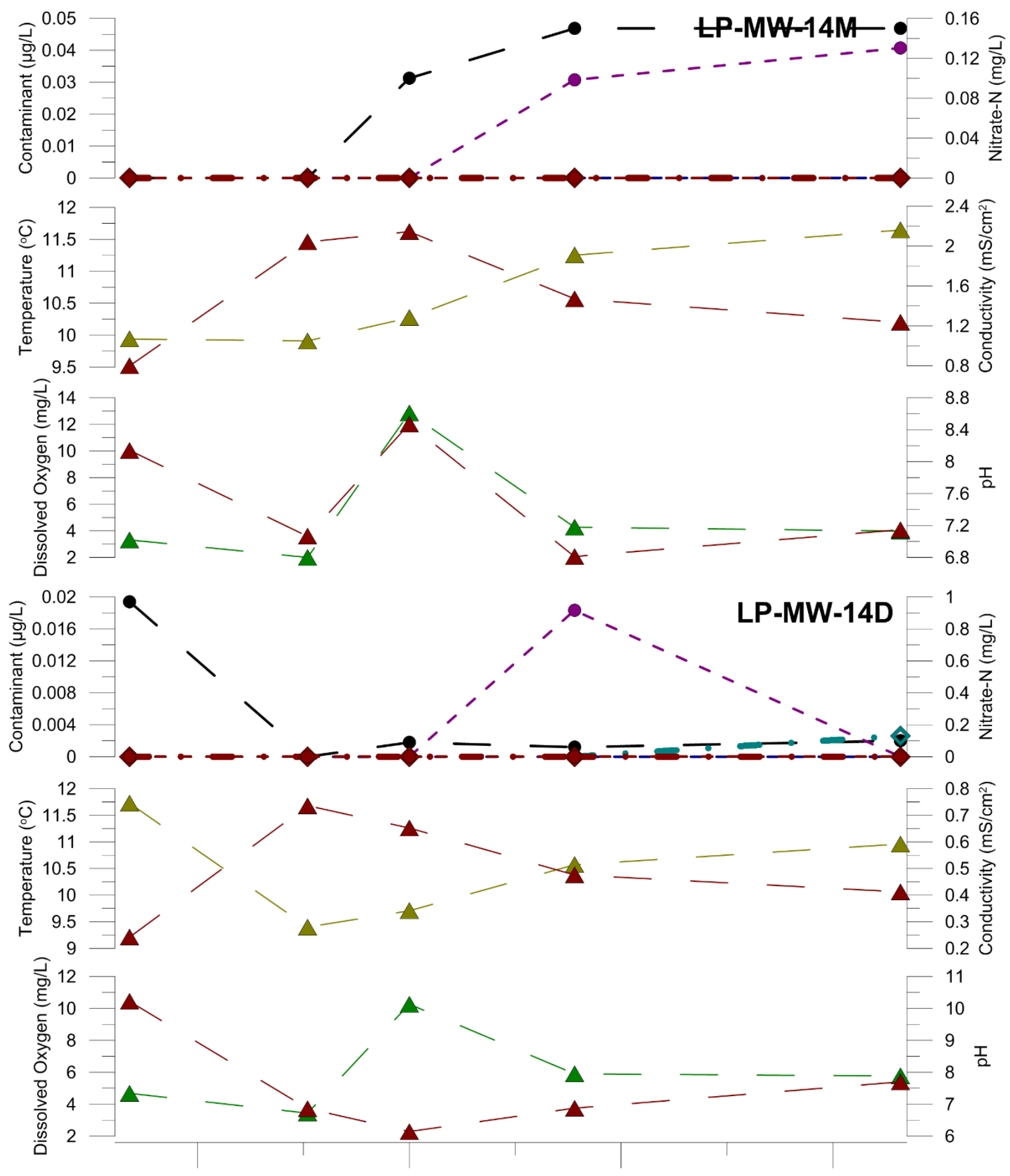

May 10, 2016 Aug 18, 2016 Date Nov 26, $2016 \quad$ Mar 06, 2017

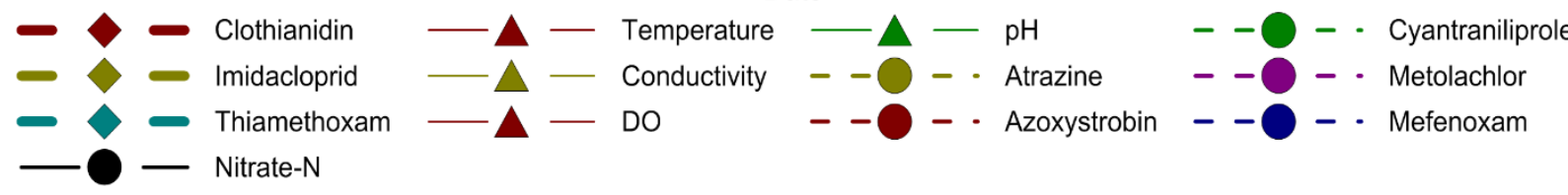



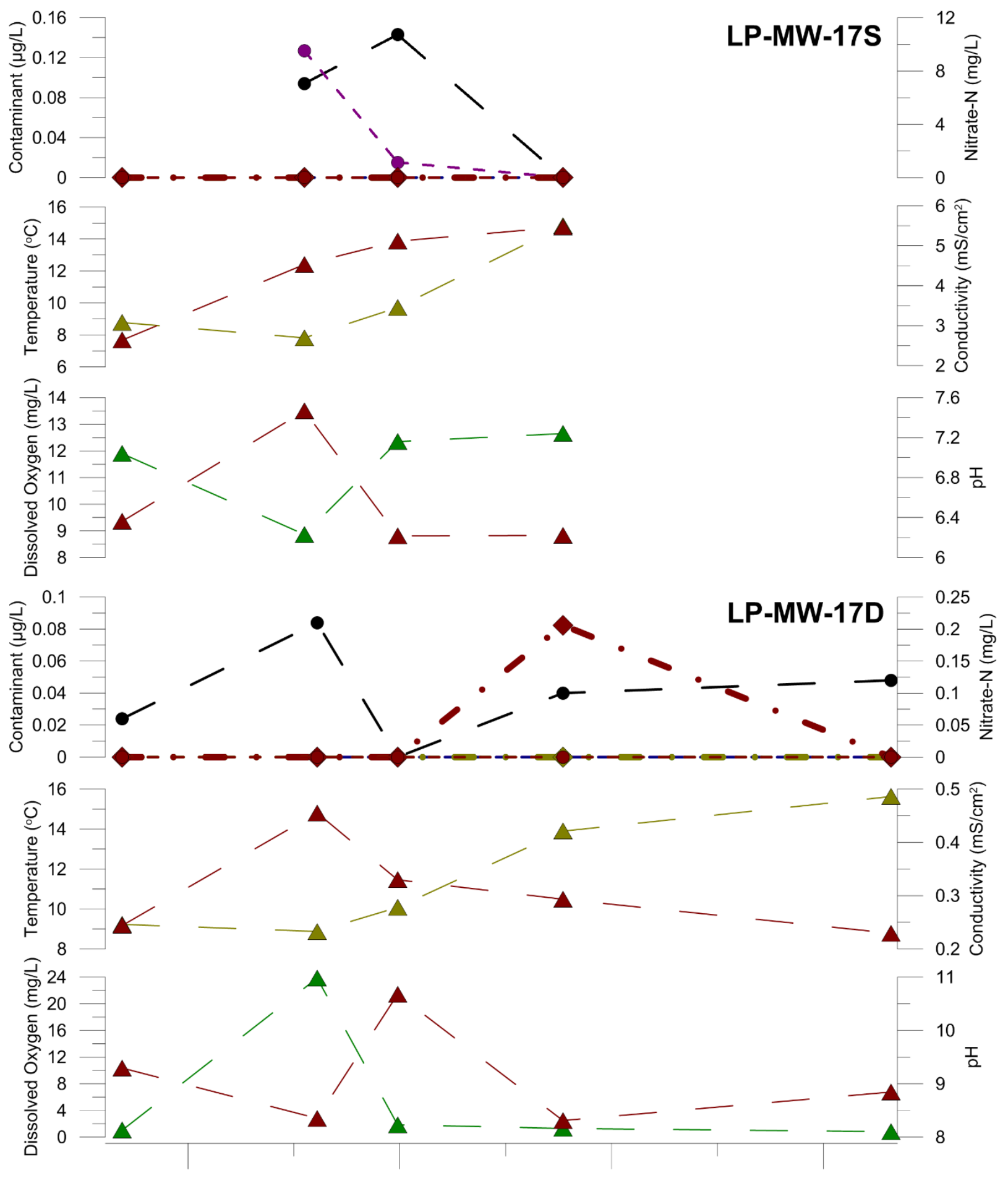

May 10, $2016 \quad$ Aug 18, $2016 \quad$ Nov 26, $2016 \quad$ Mar 06, 2017

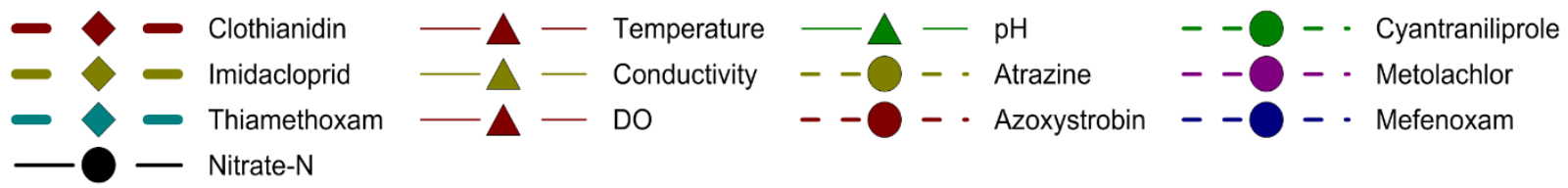



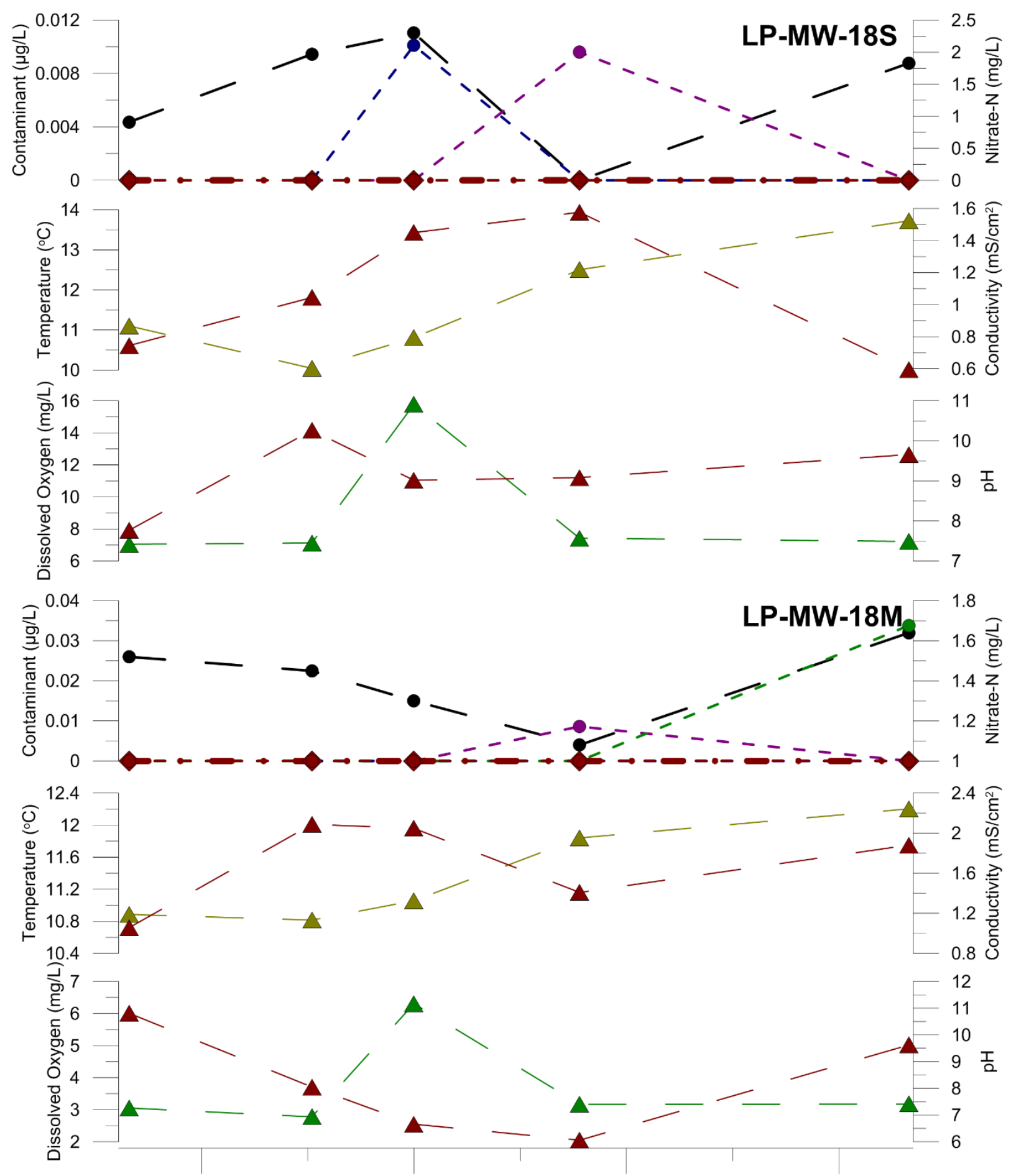

May 10, $2016 \quad$ Aug 18, $2016 \quad$ Nov 26, $2016 \quad$ Mar 06, 2017

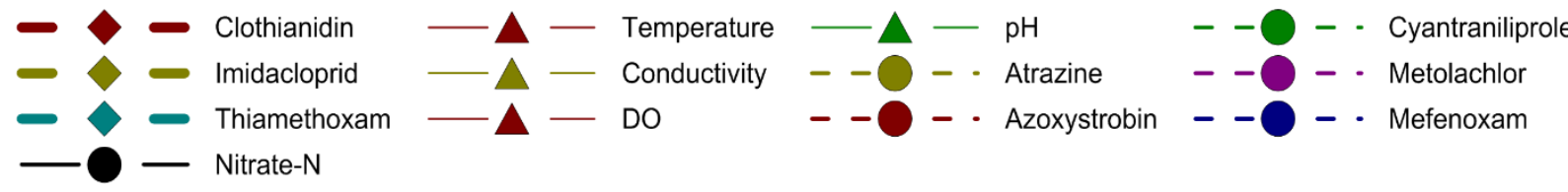



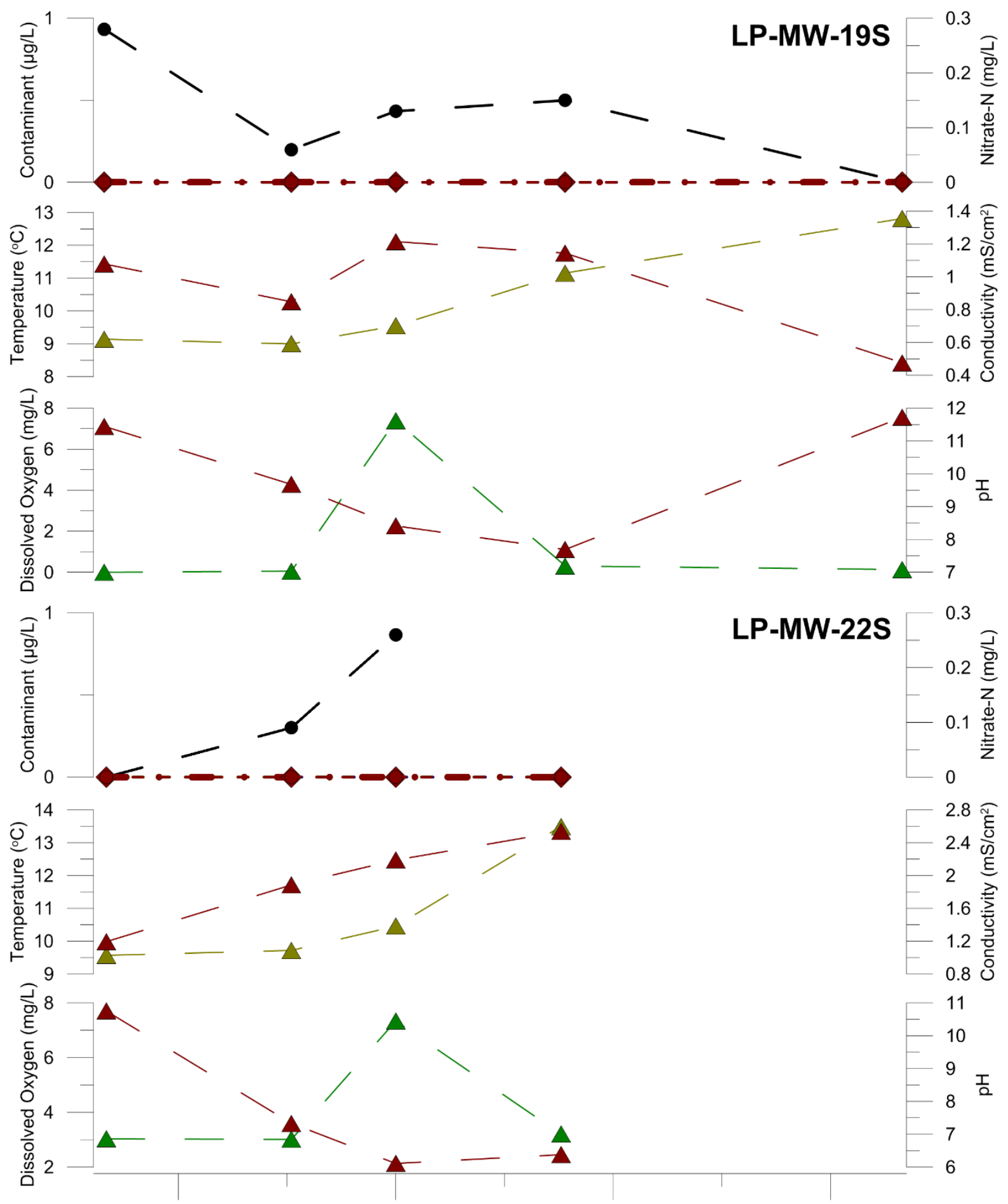

May 10, $2016 \quad$ Aug 18, $2016 \quad$ Nov 26, $2016 \quad$ Mar 06, 2017

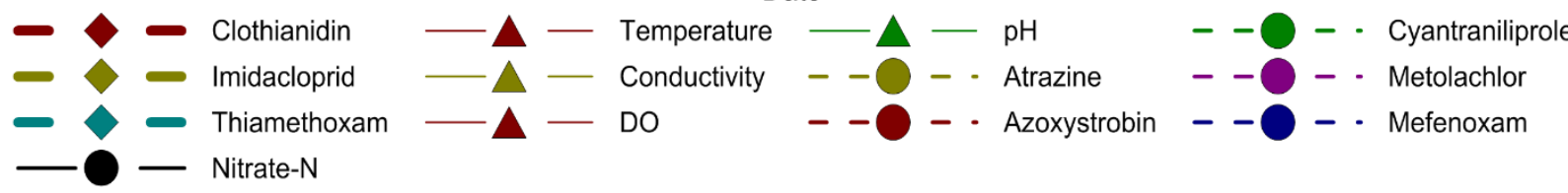



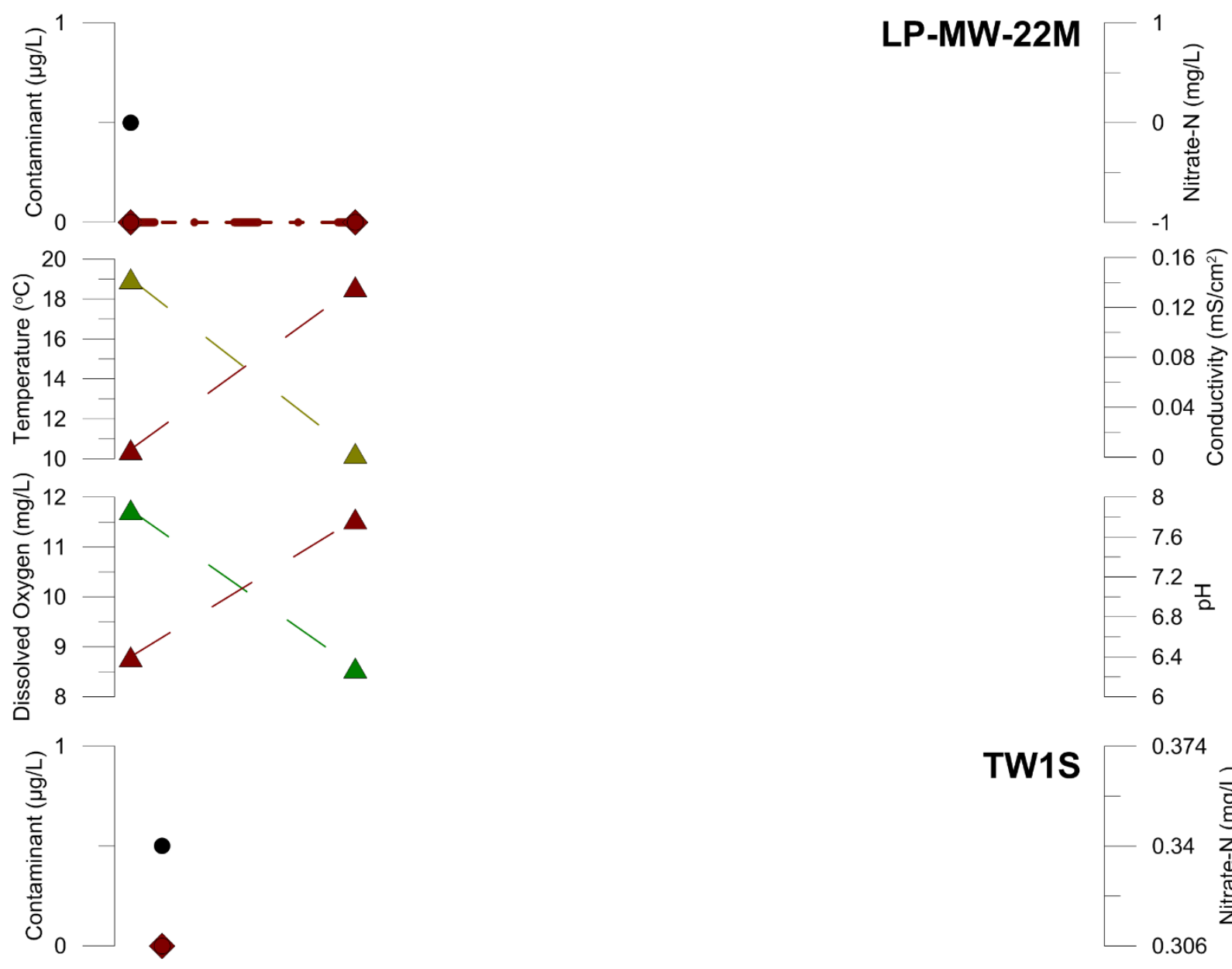

TW1S
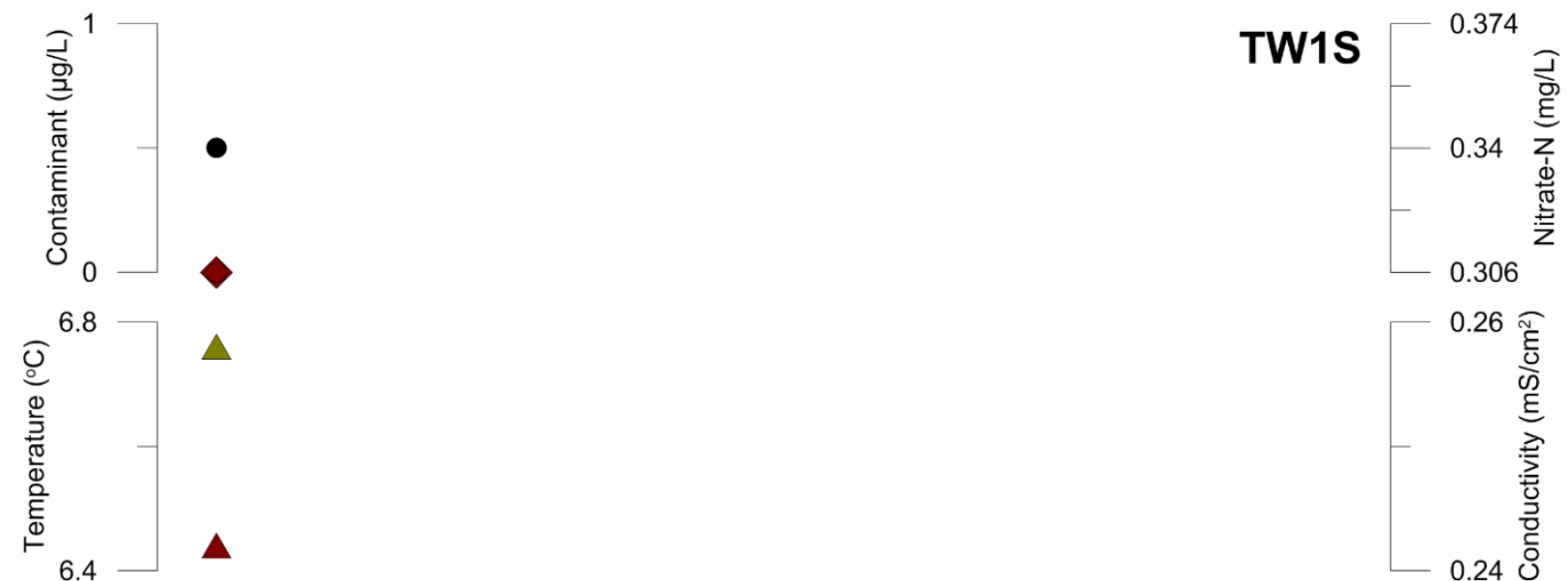

$\Delta$
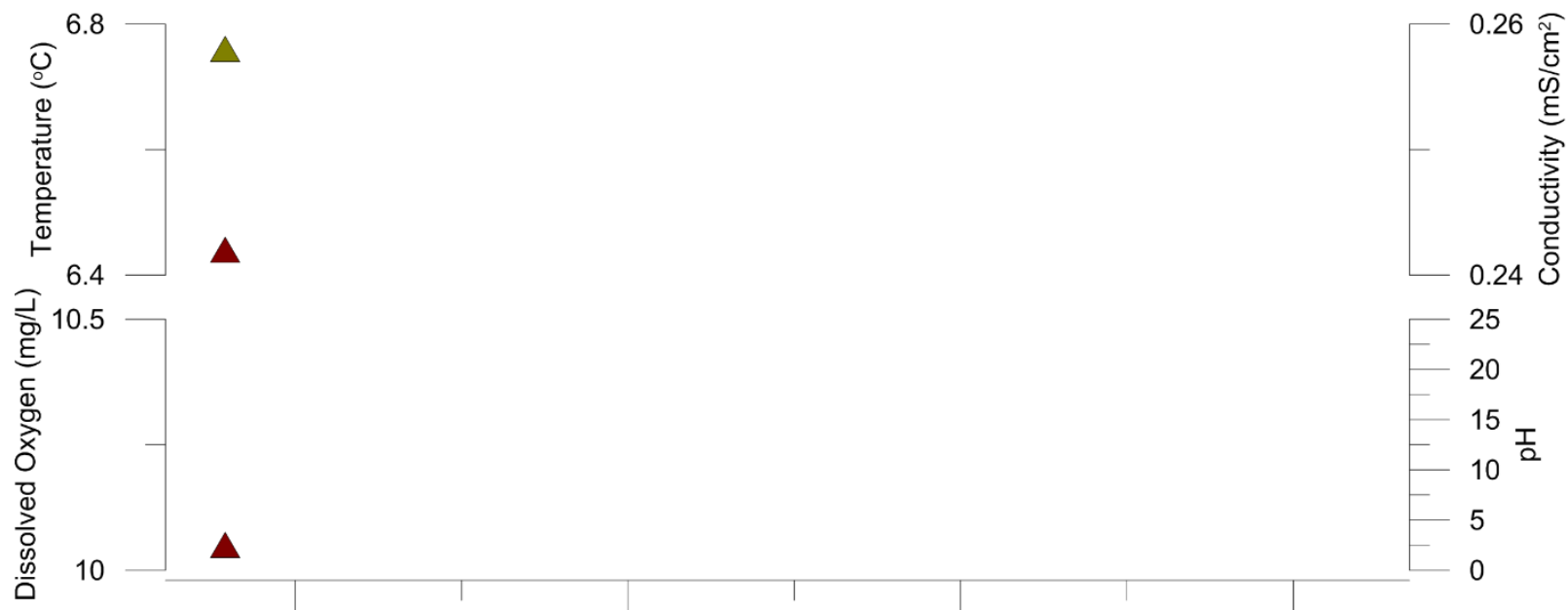

$\Delta$

25

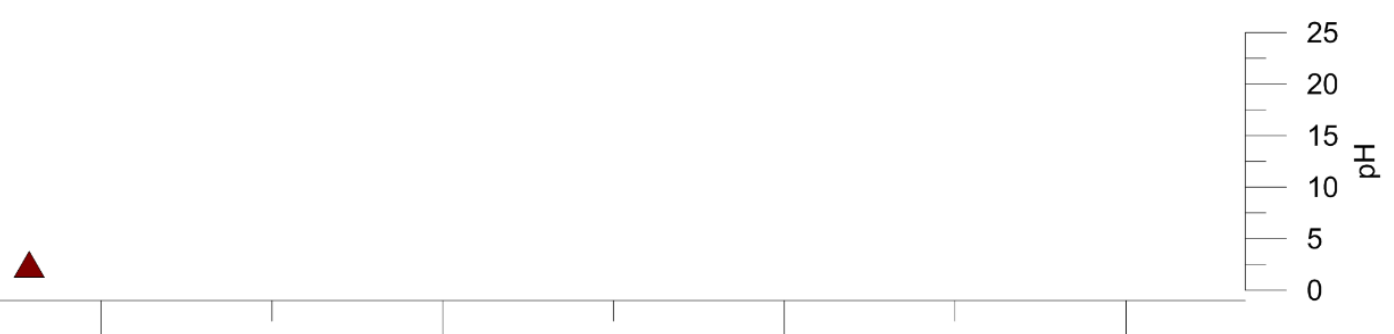

May 10, 2016

Aug 18, 2016

Nov 26, 2016

Mar 06, 2017





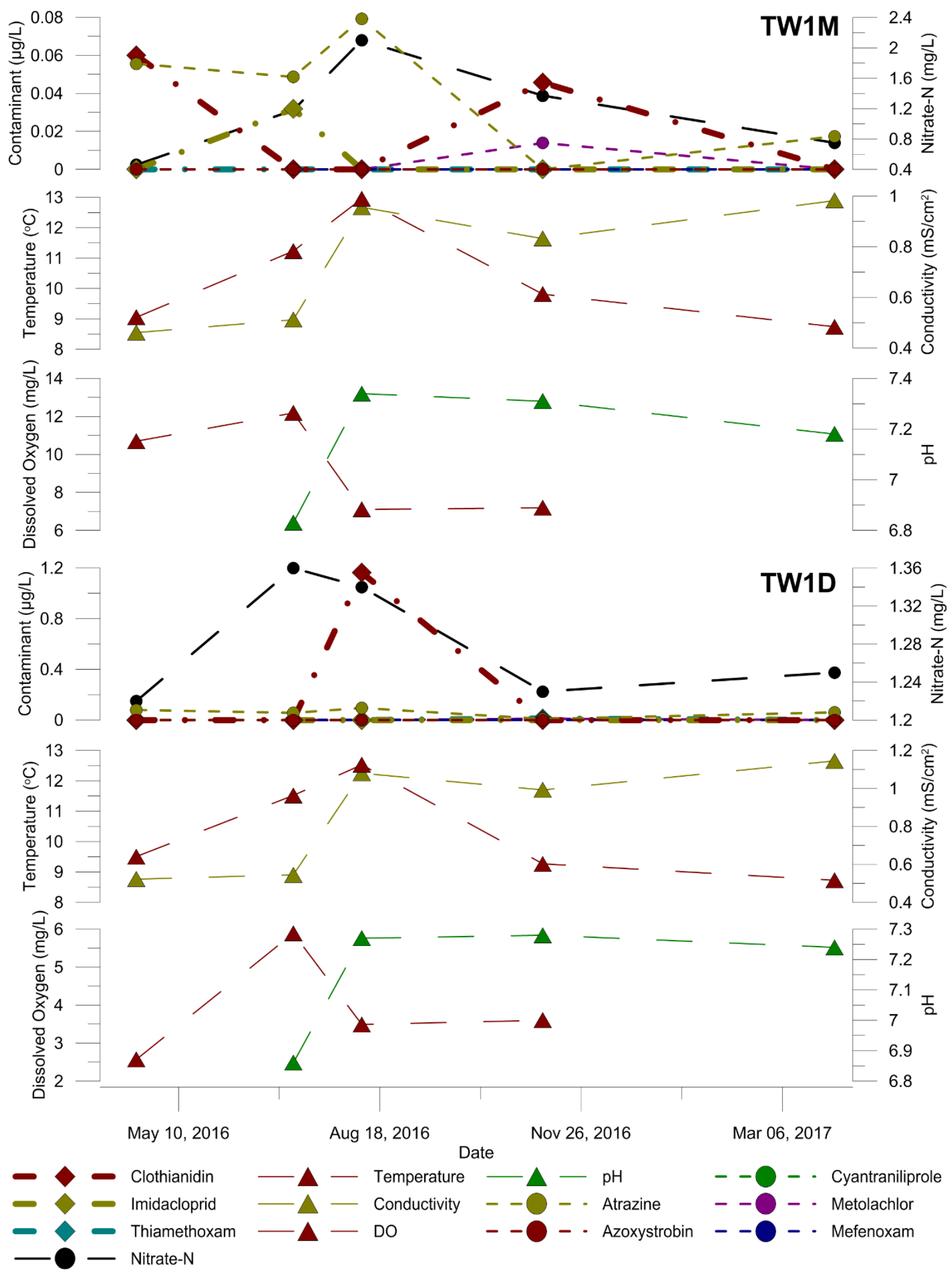


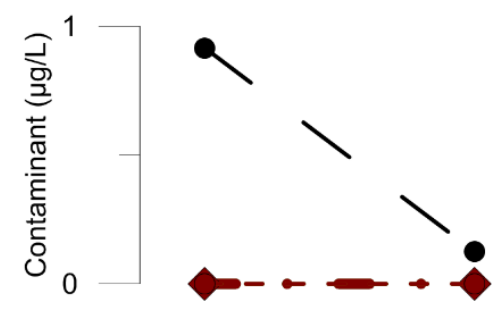

TW3S

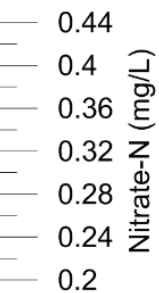

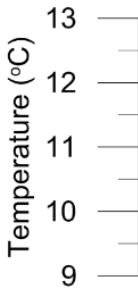
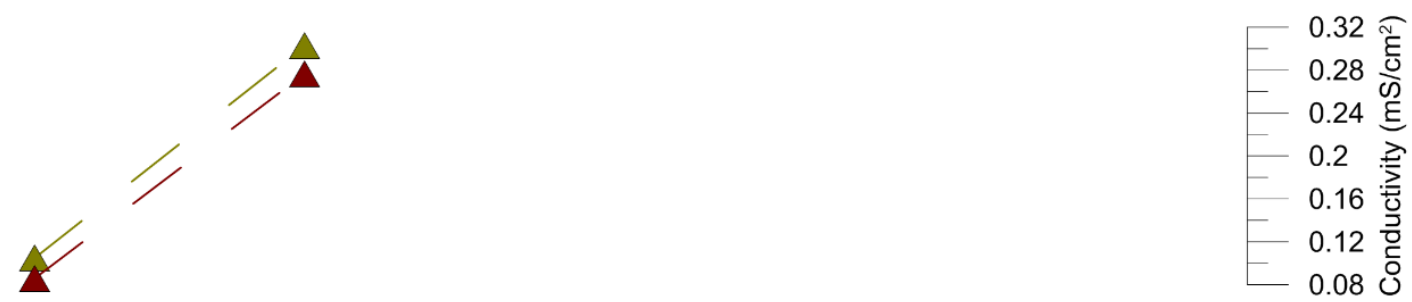

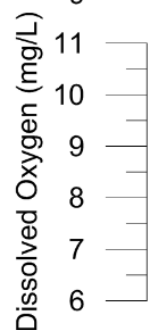
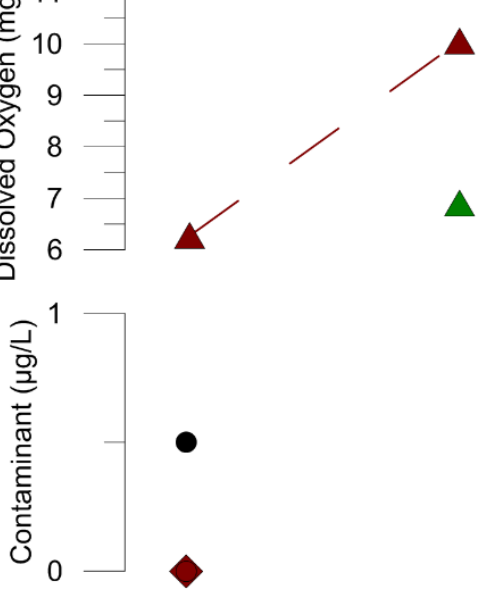

TW4S

11.5

동
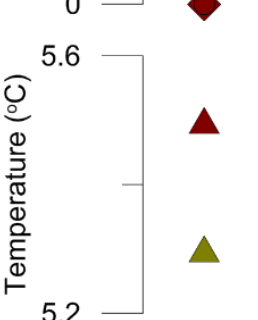

$\Delta$

5.2

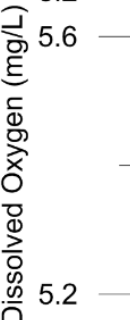

$\Delta$

0.209
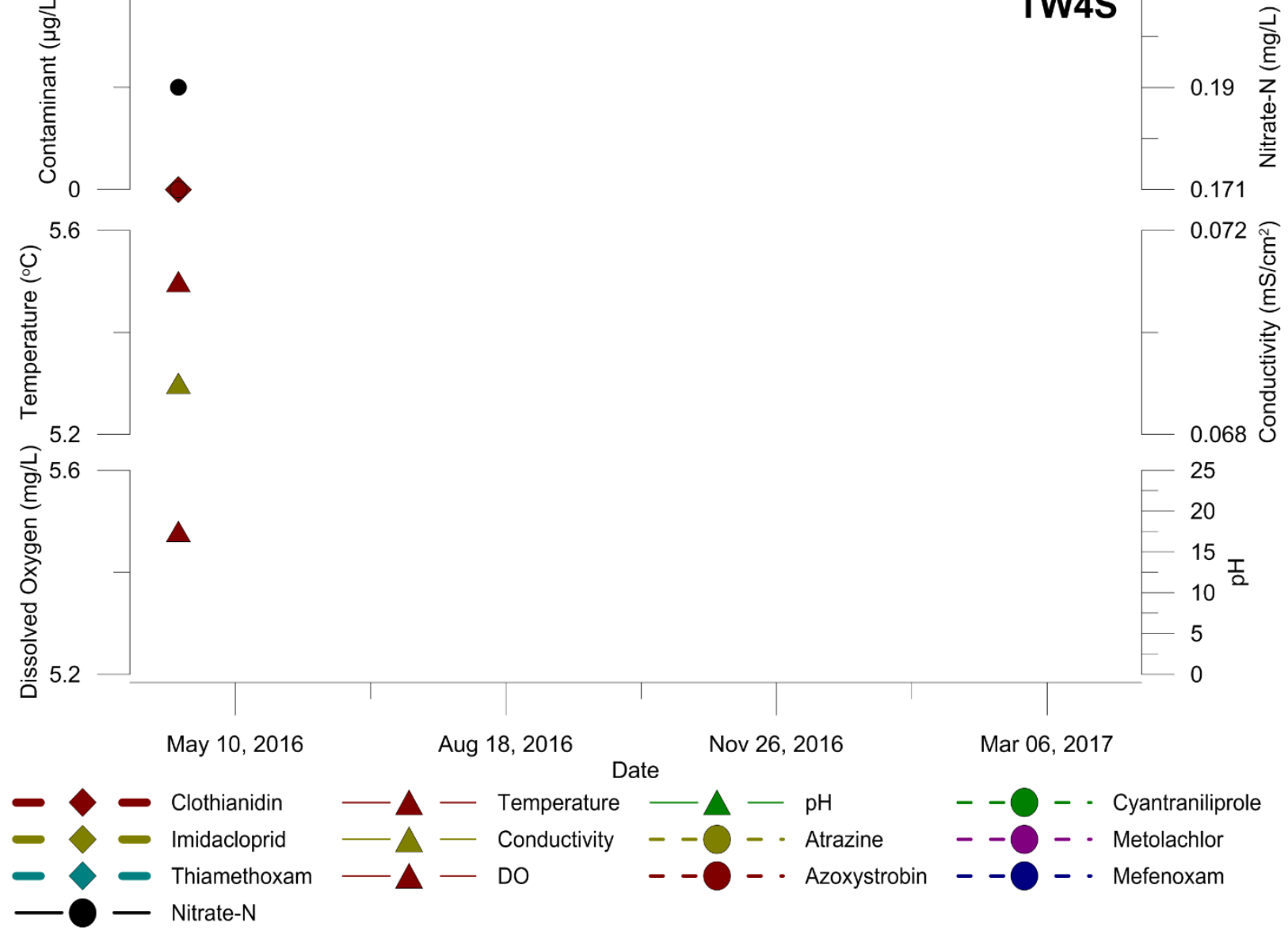

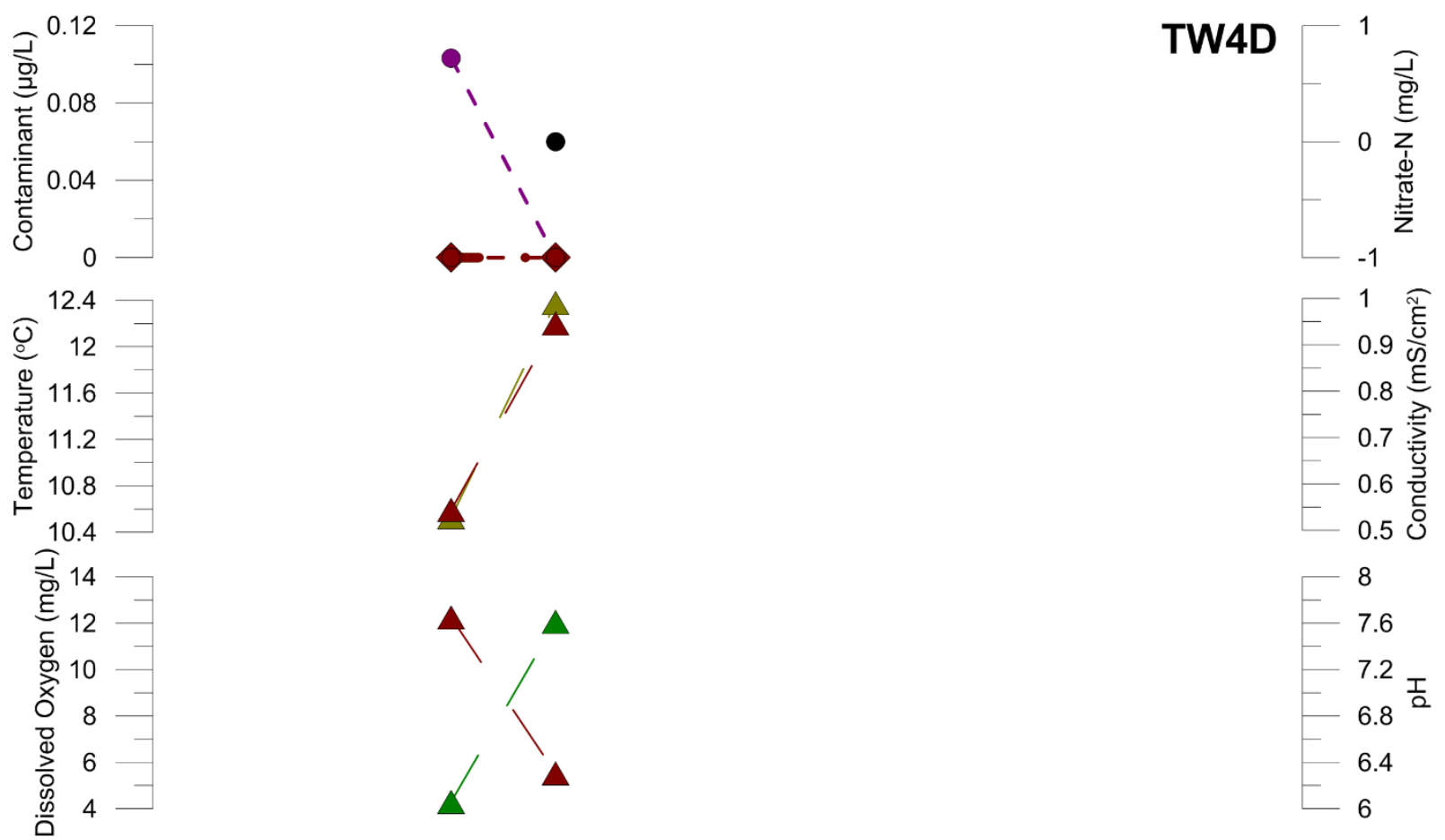

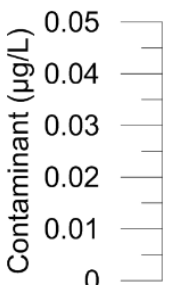
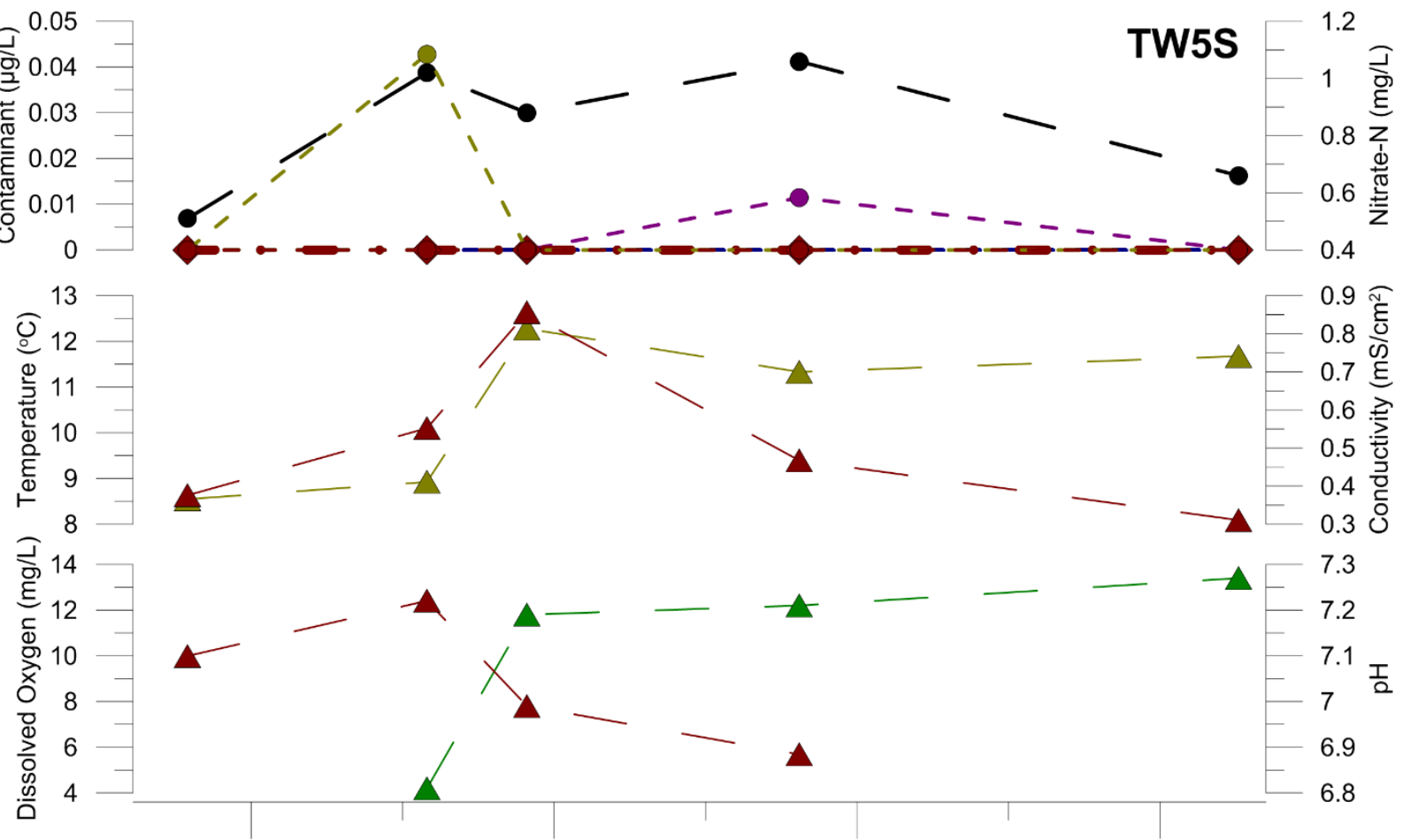

May 10, 2016

Aug 18, 2016

Nov 26, 2016

Mar 06, 2017

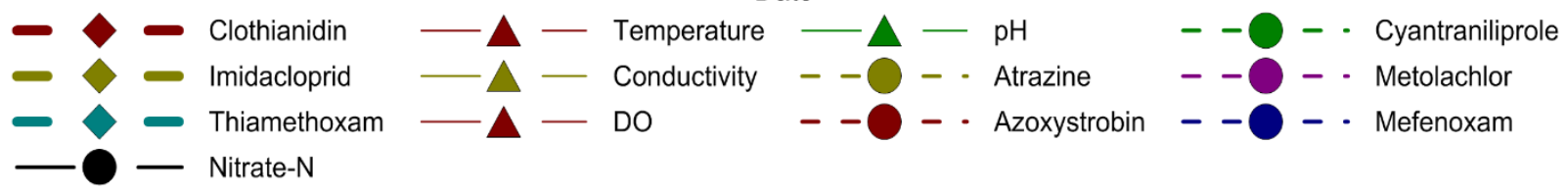



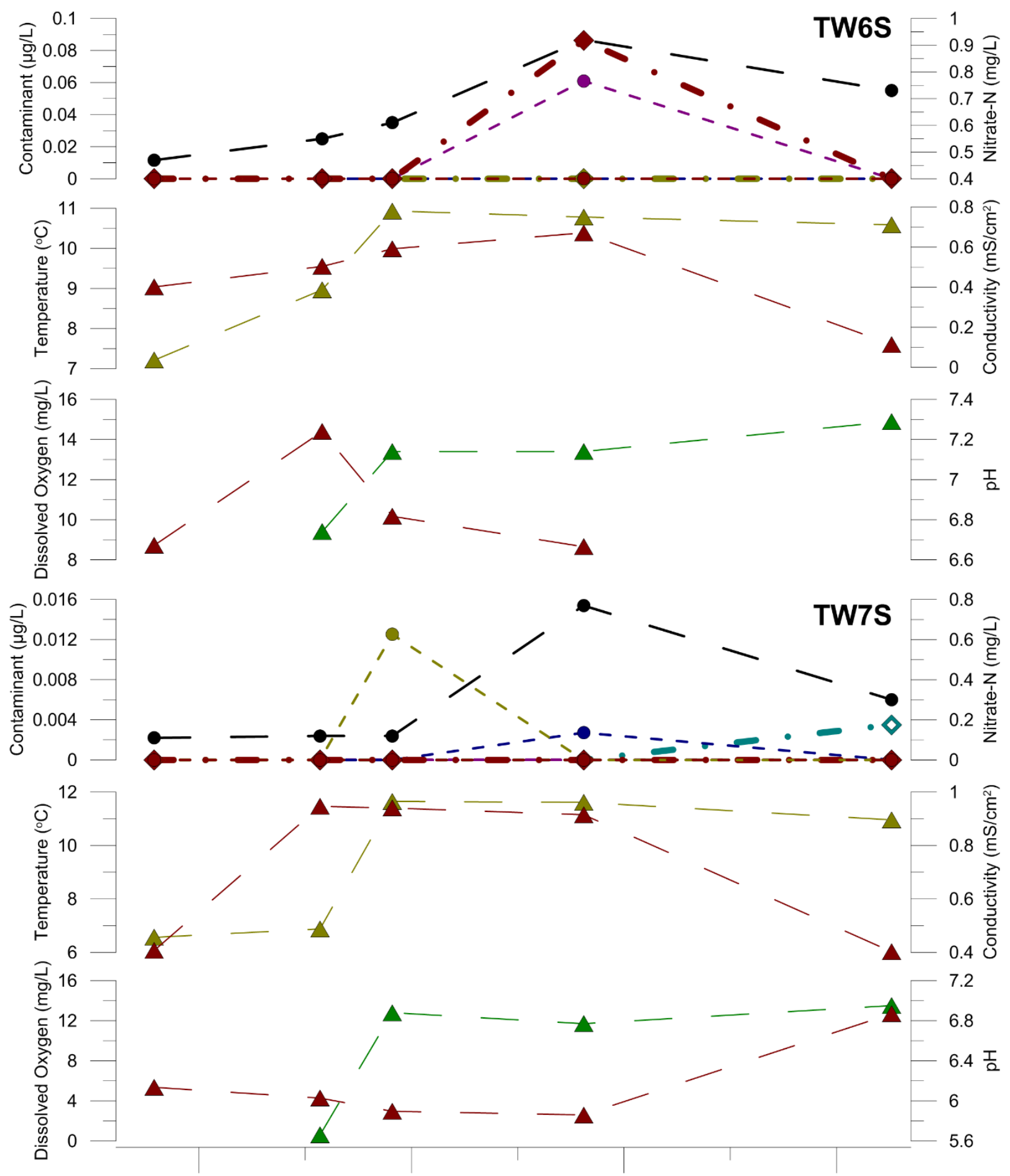

May 10, $2016 \quad$ Aug 18, 2016 Nov 26, $2016 \quad$ Mar 06, 2017

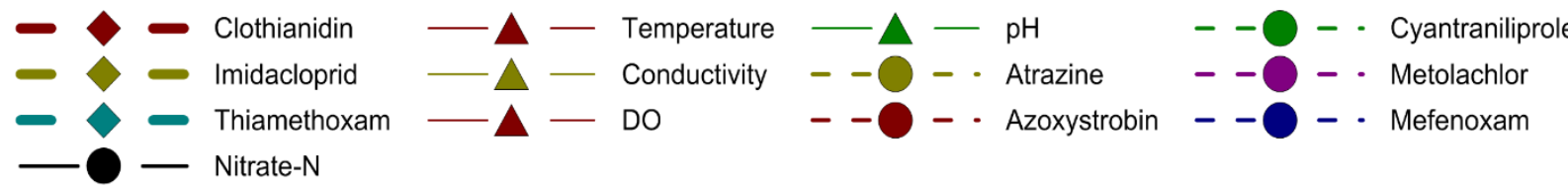



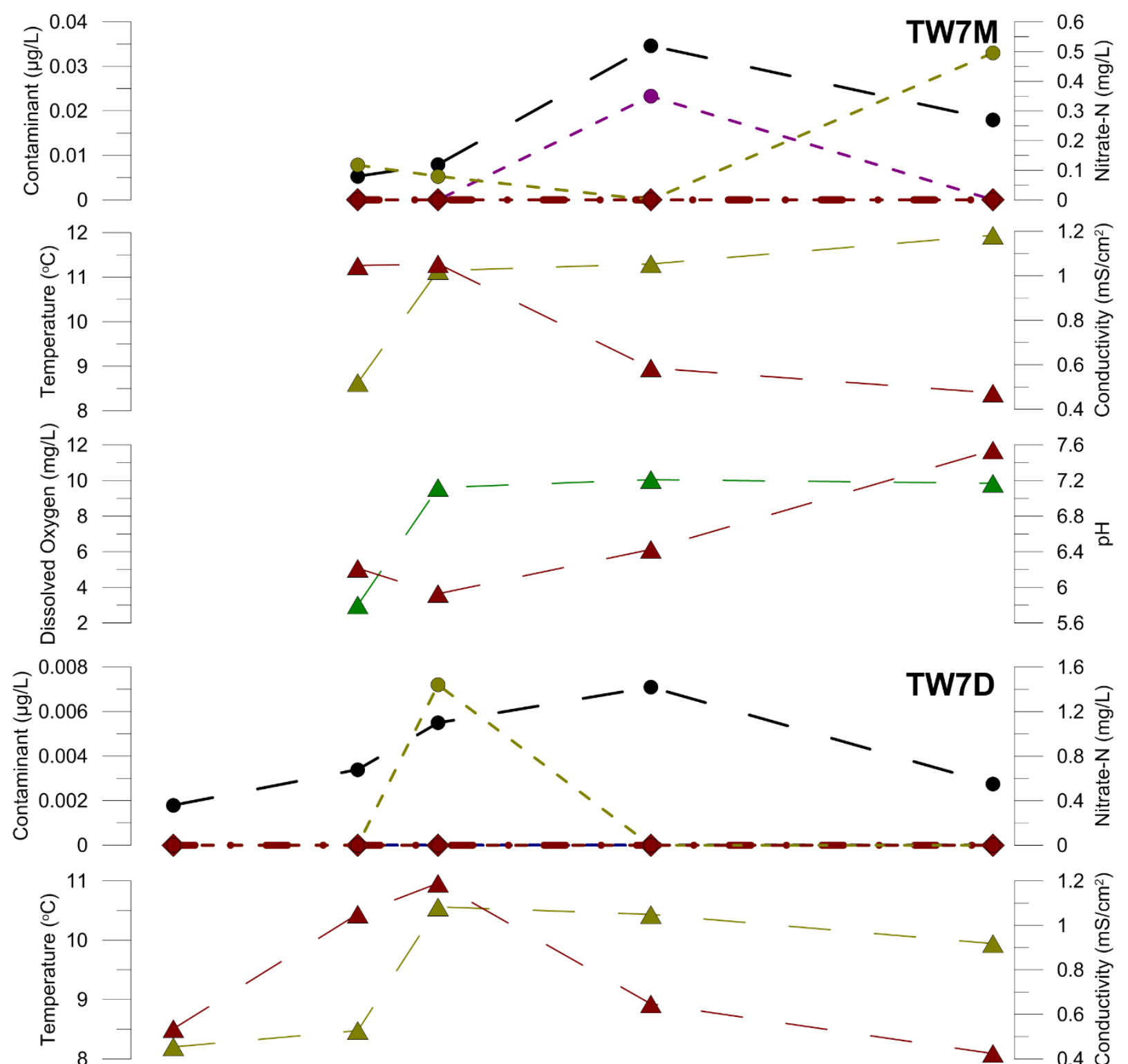


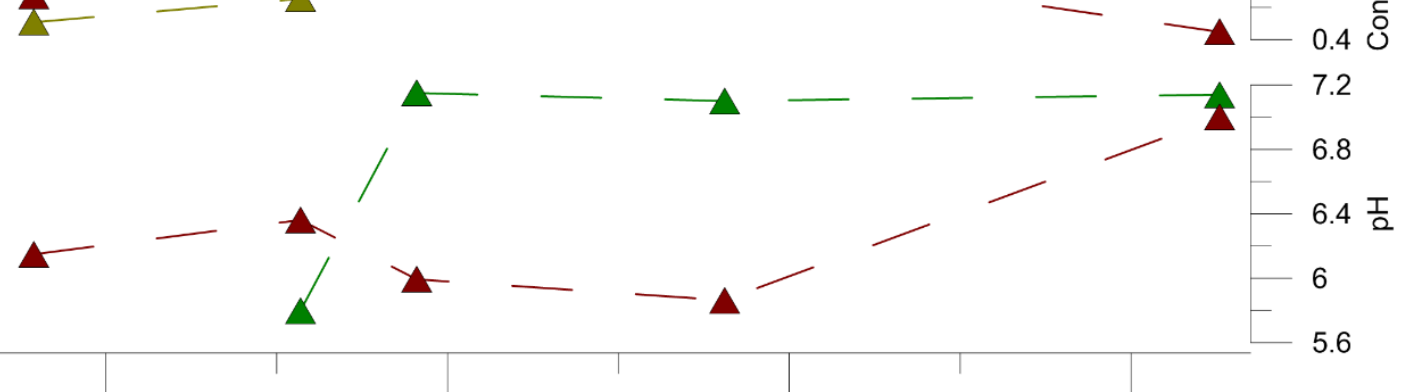

May 10, 2016

Aug 18, 2016

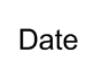

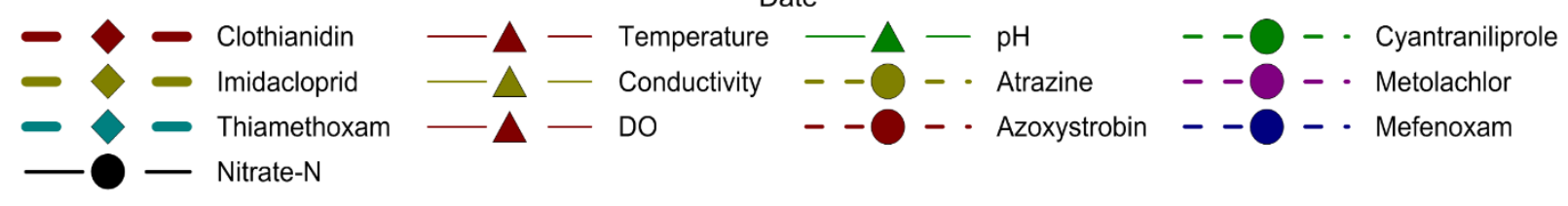



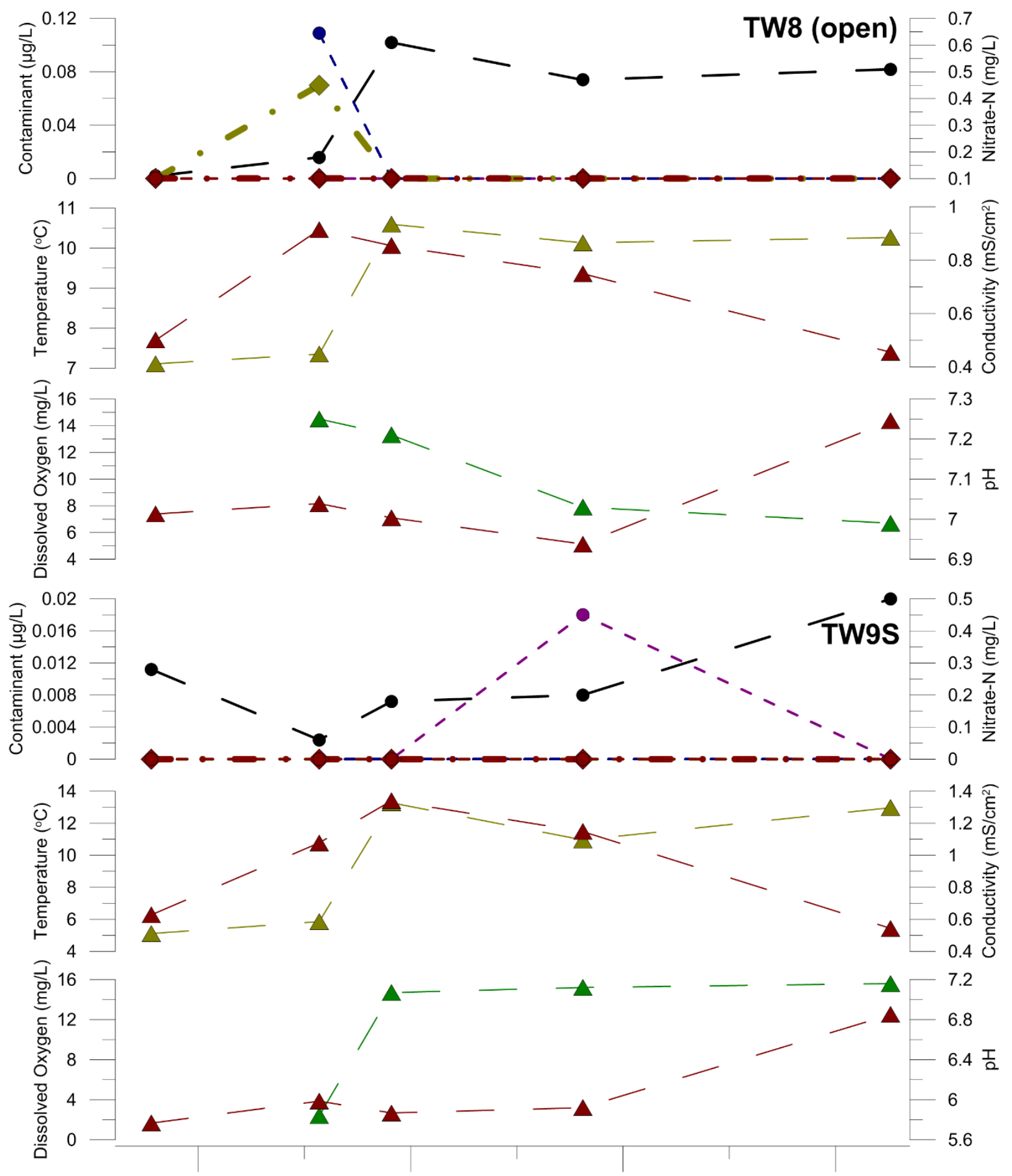

May 10, $2016 \quad$ Aug 18, $2016 \quad$ Nov 26, $2016 \quad$ Mar 06, 2017

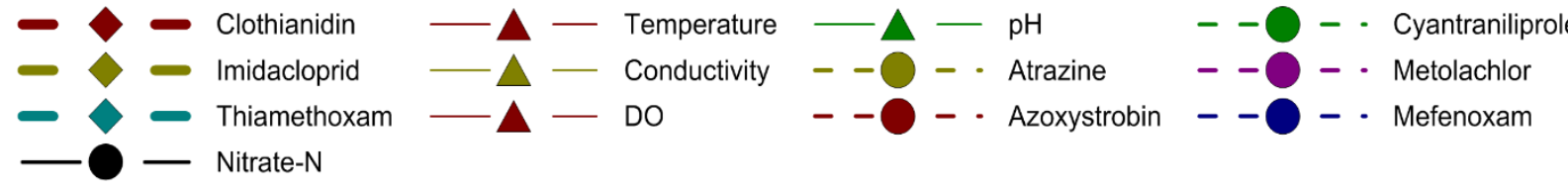




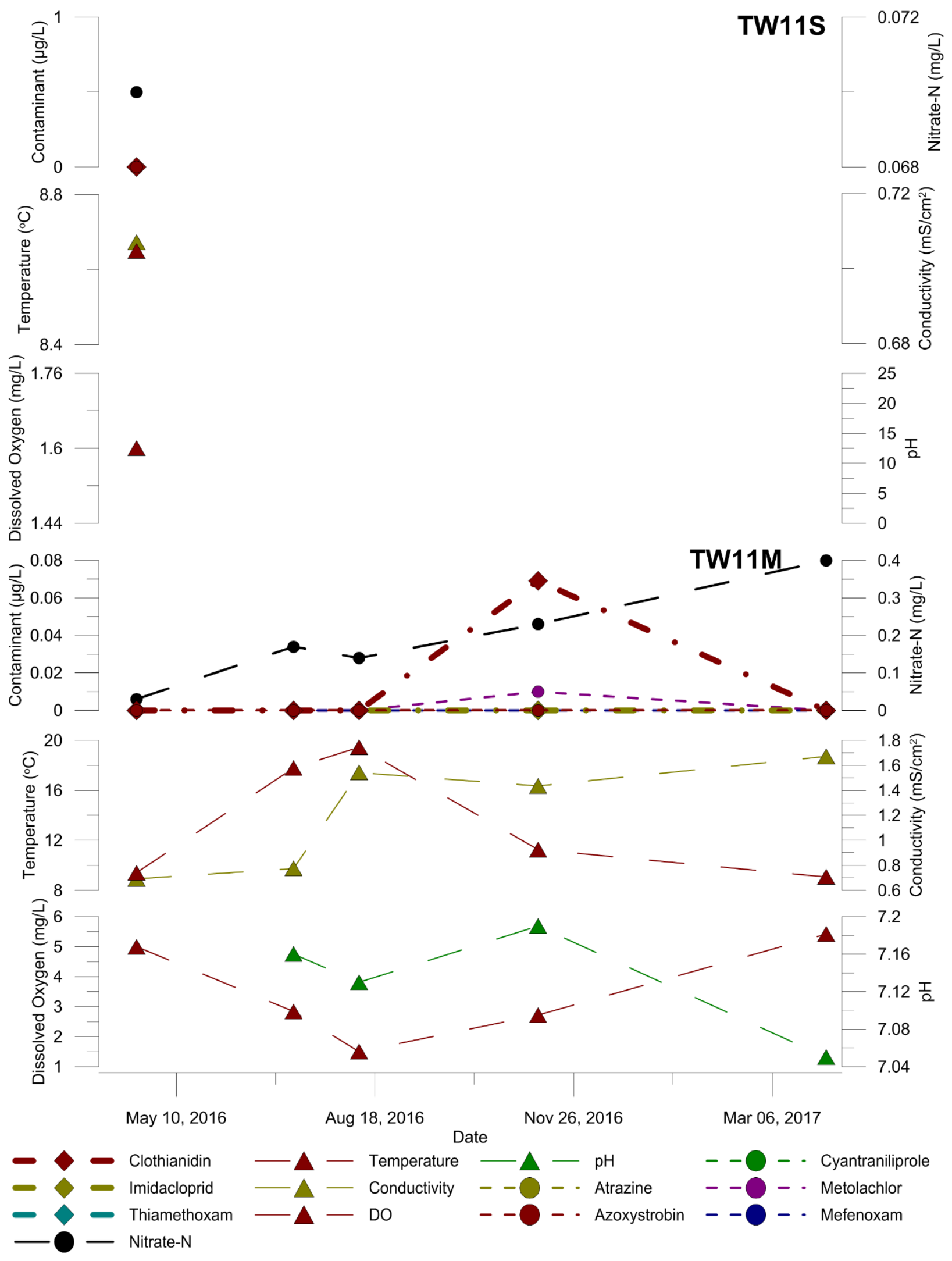



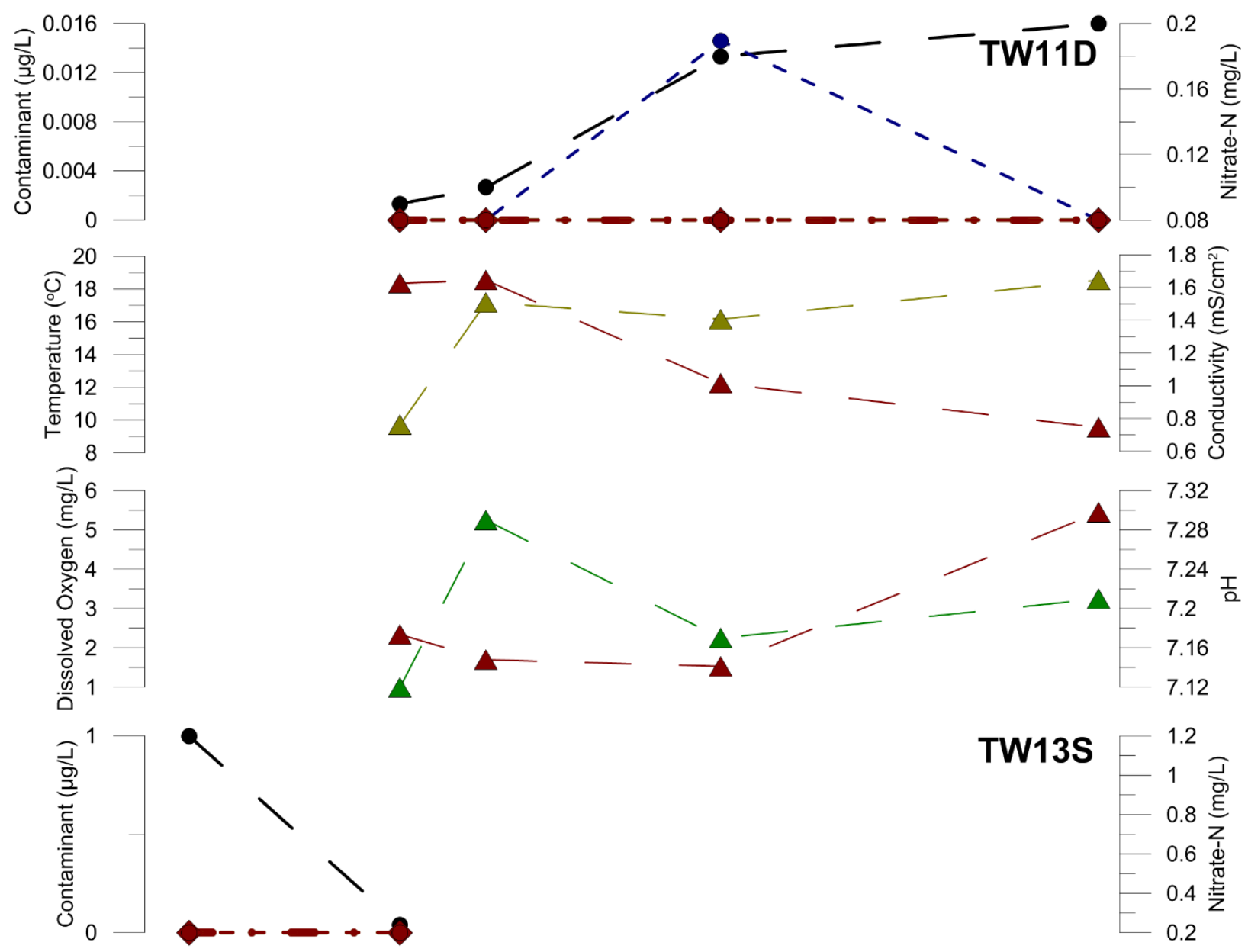

TW13S
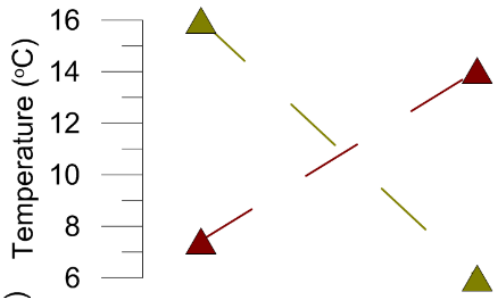

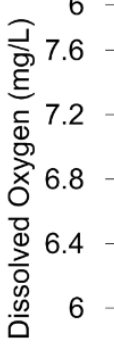
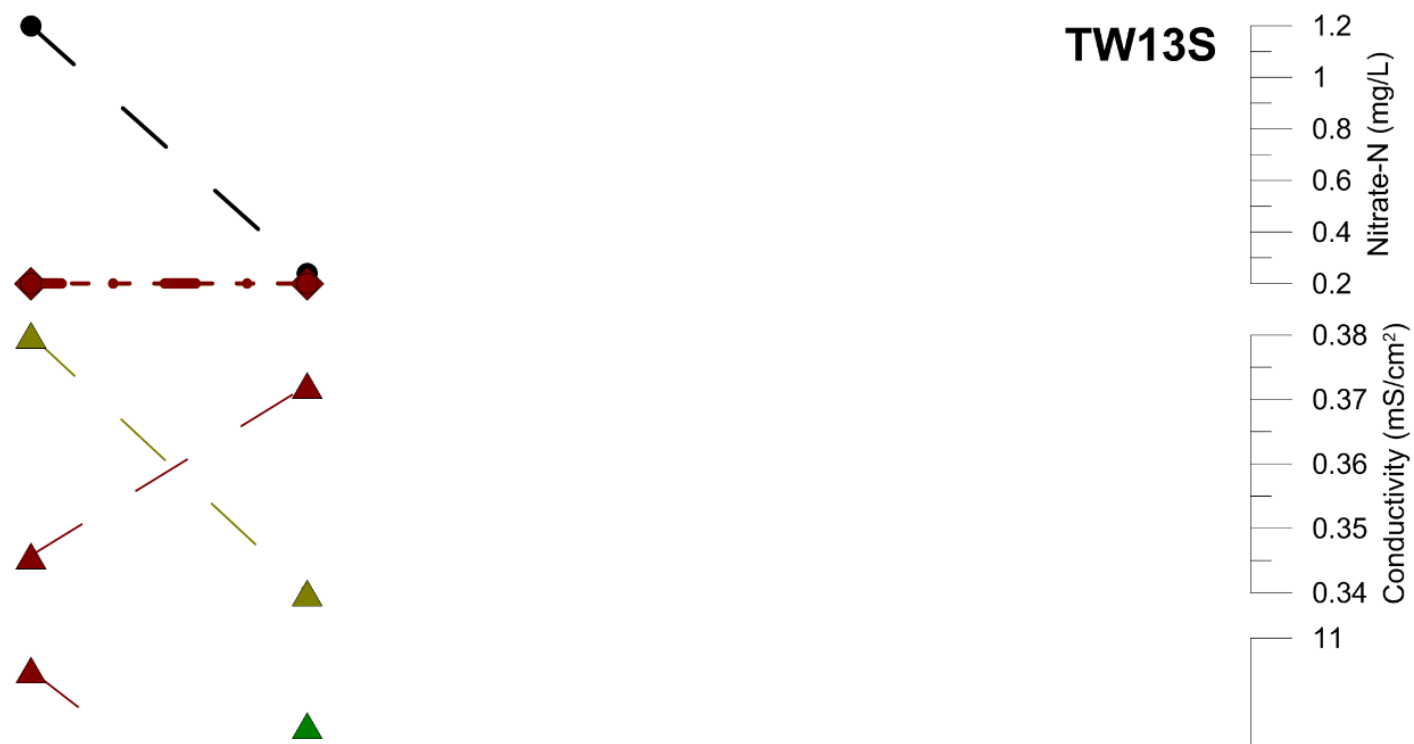

May 10, 2016

Aug 18, 2016

Nov 26, 2016

Mar 06, 2017

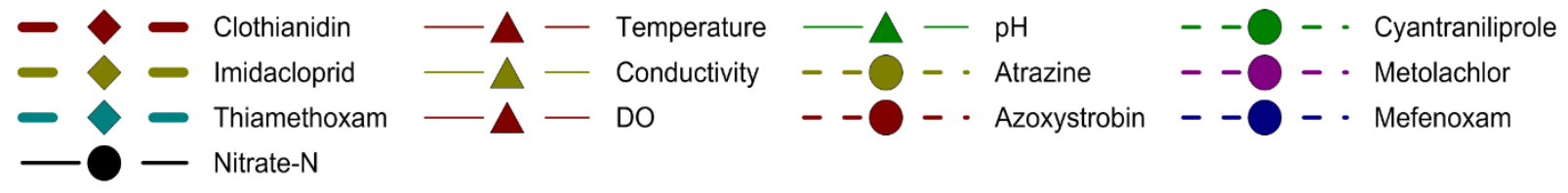



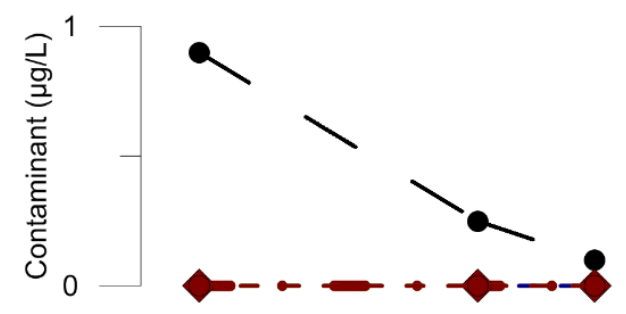

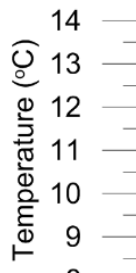
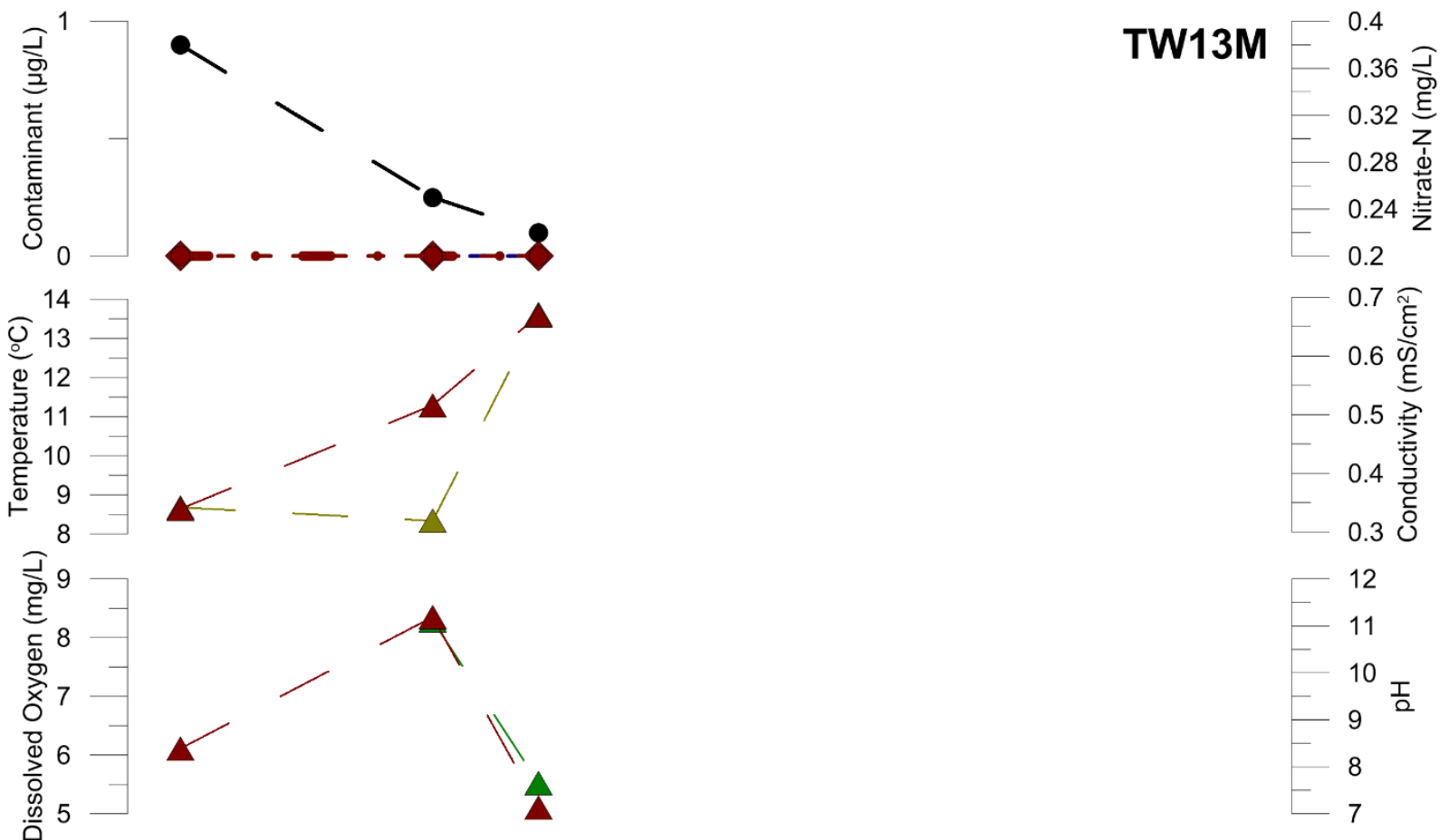

- 0.7 ส

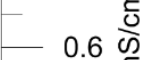

6 ह

-0.5 ?

- 0.4 른

- 0.3 वृ

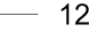

- 11

$-10$

- $9^{\frac{T}{2}}$

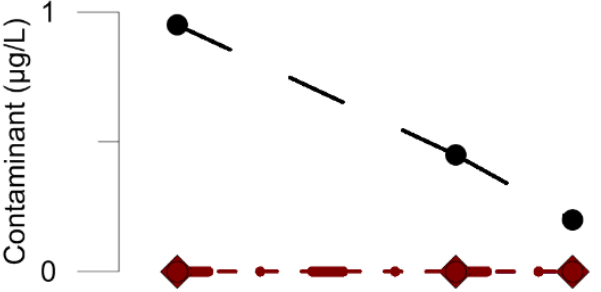

TW13D

- 8

- 7

\section{(1)} 工

8

$-7$
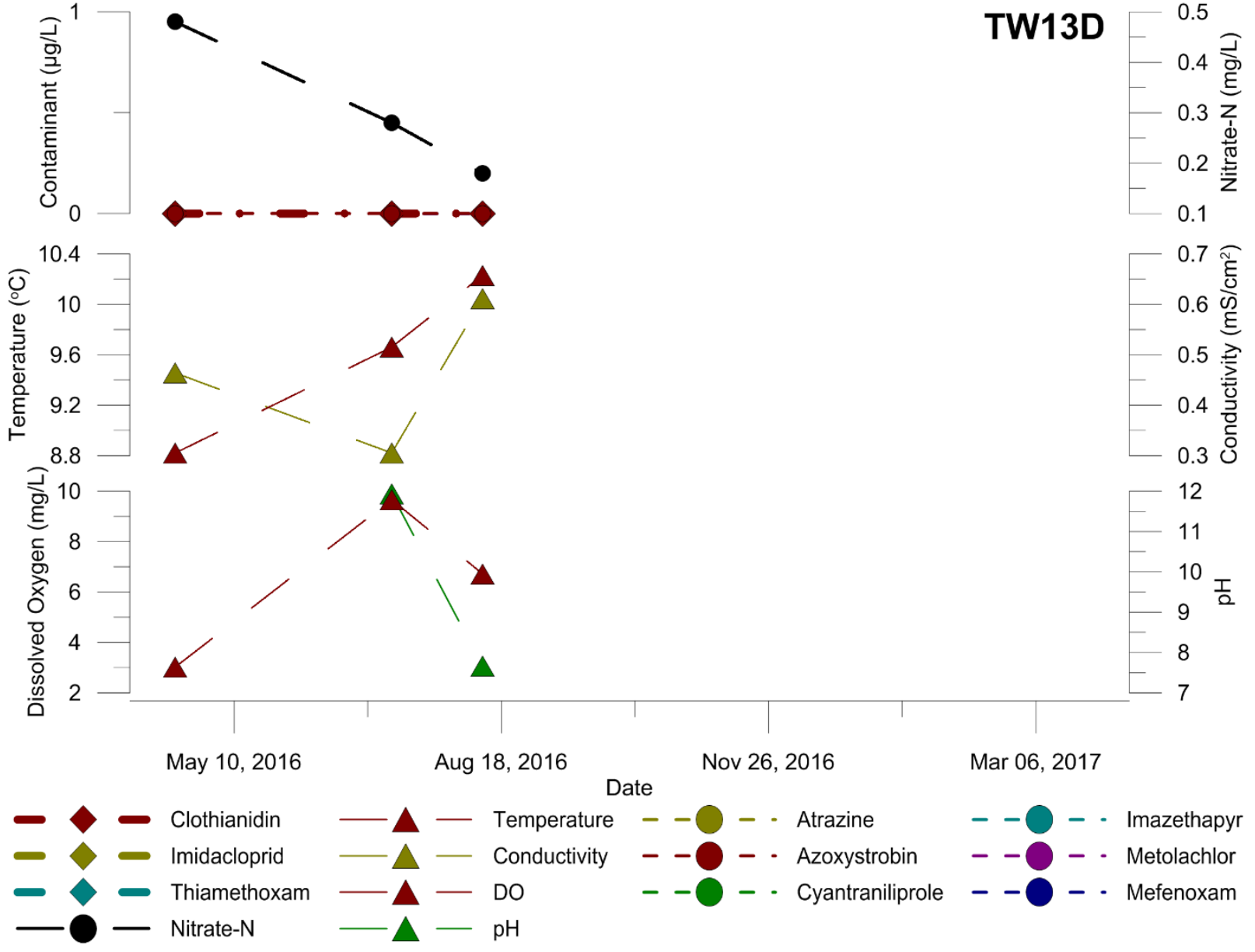

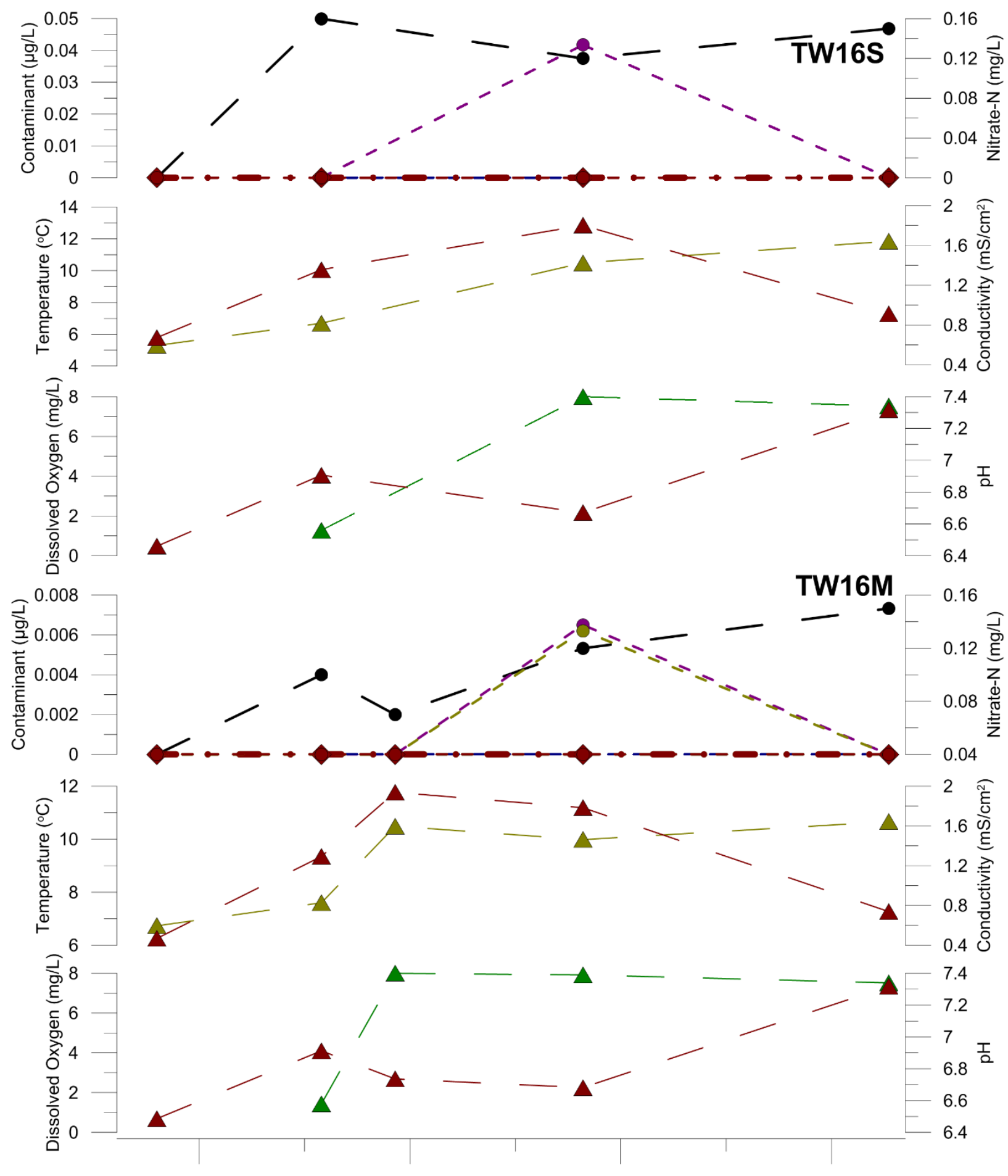

May 10, 2016

Aug 18, 2016

Nov 26, 2016

Mar 06, 2017

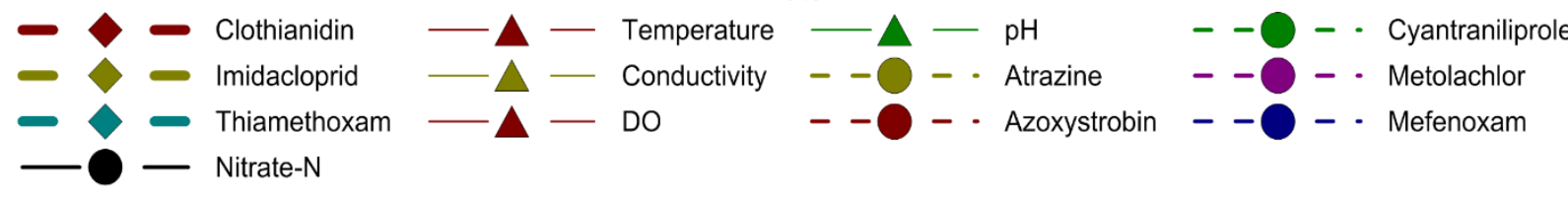



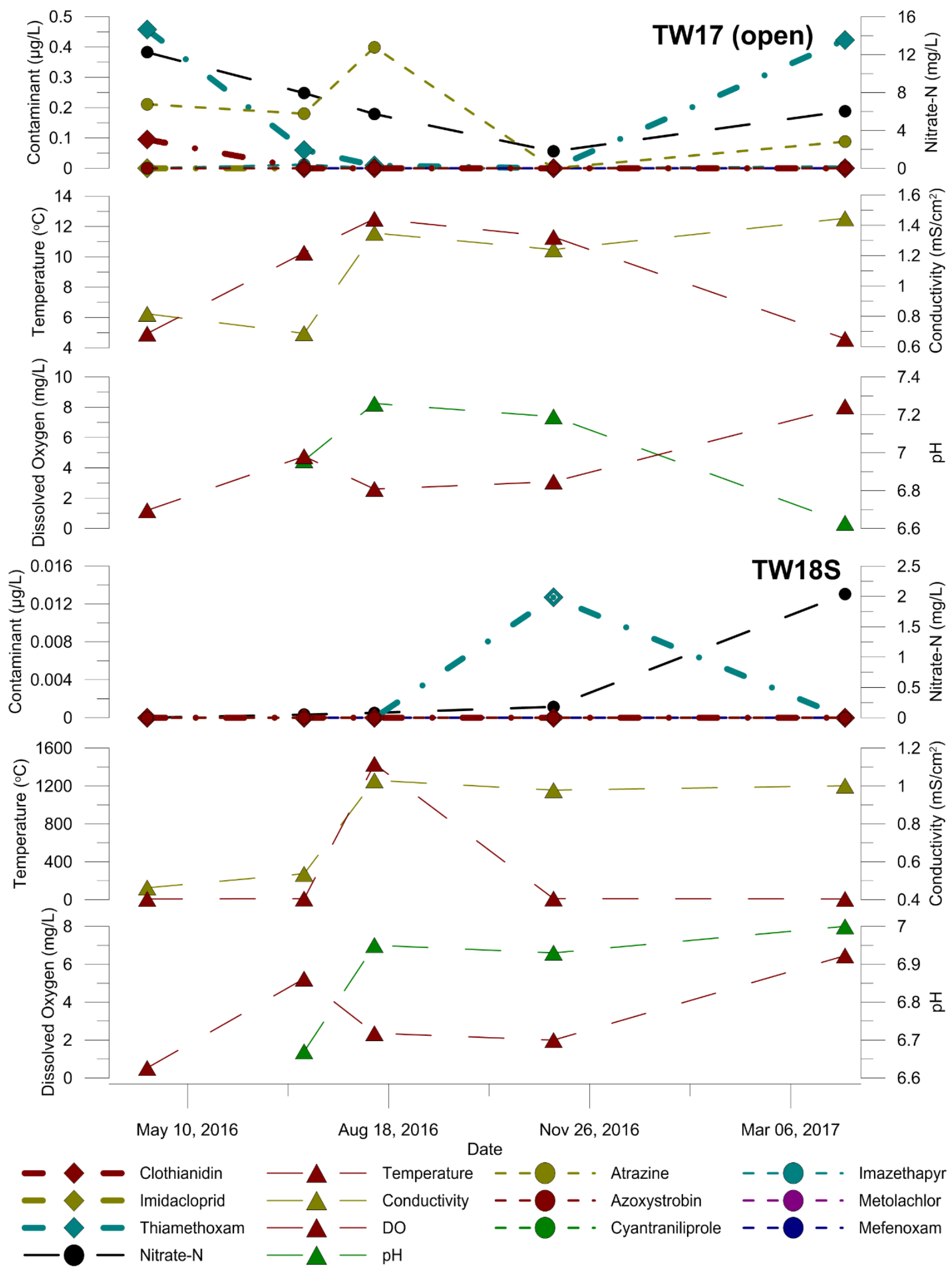

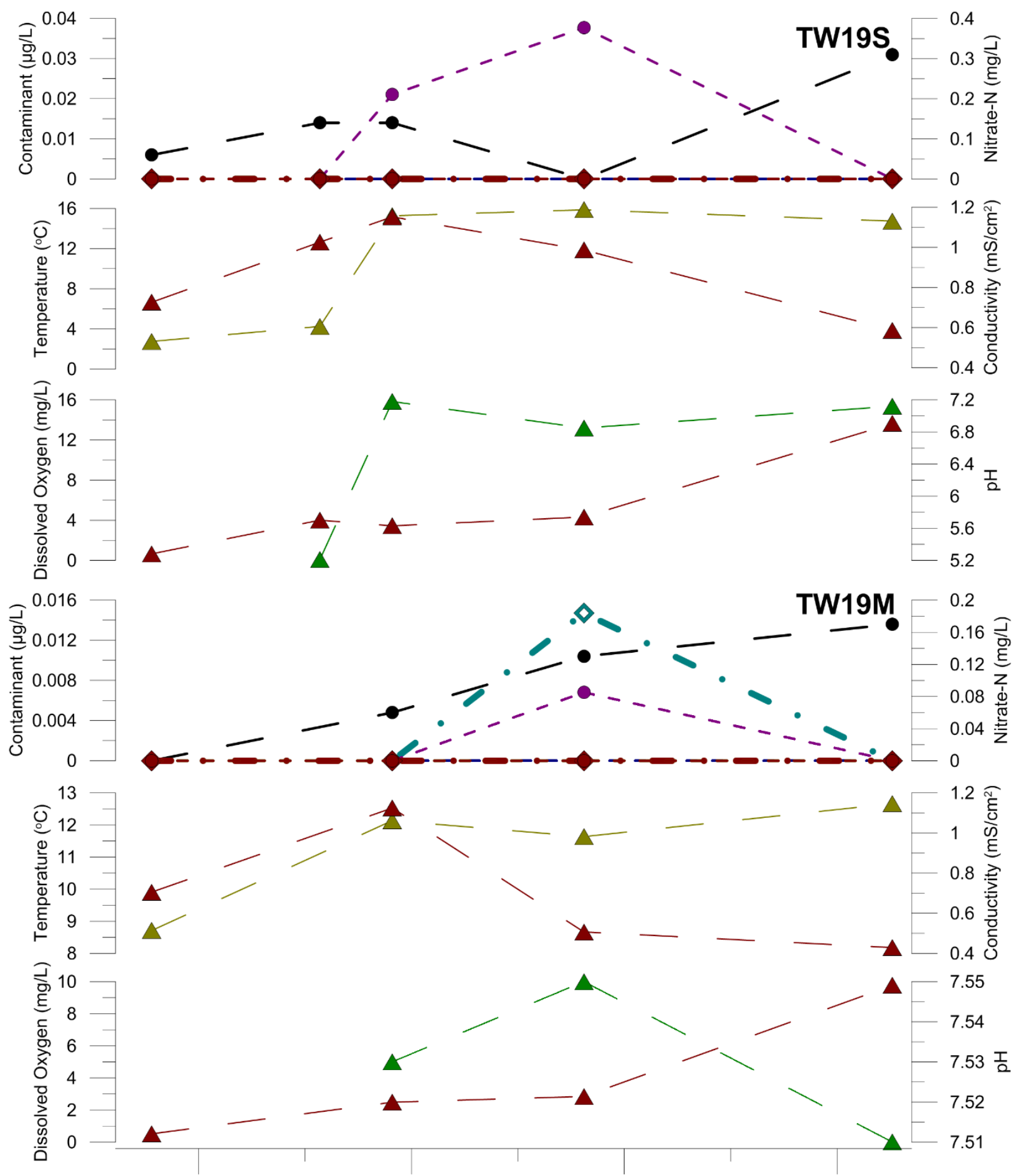

May 10, $2016 \quad$ Aug 18, $2016 \quad$ Nov 26, $2016 \quad$ Mar 06, 2017

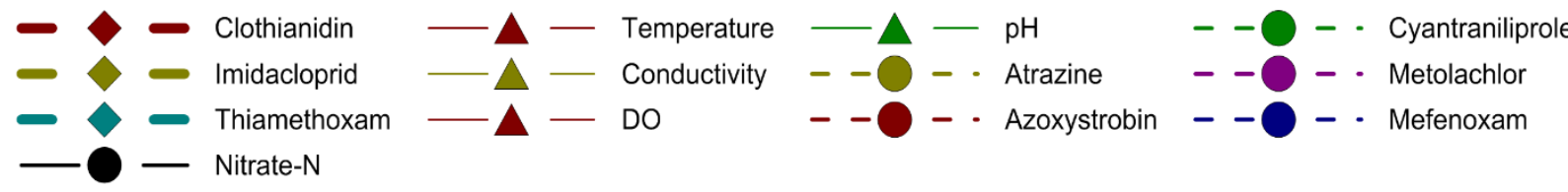



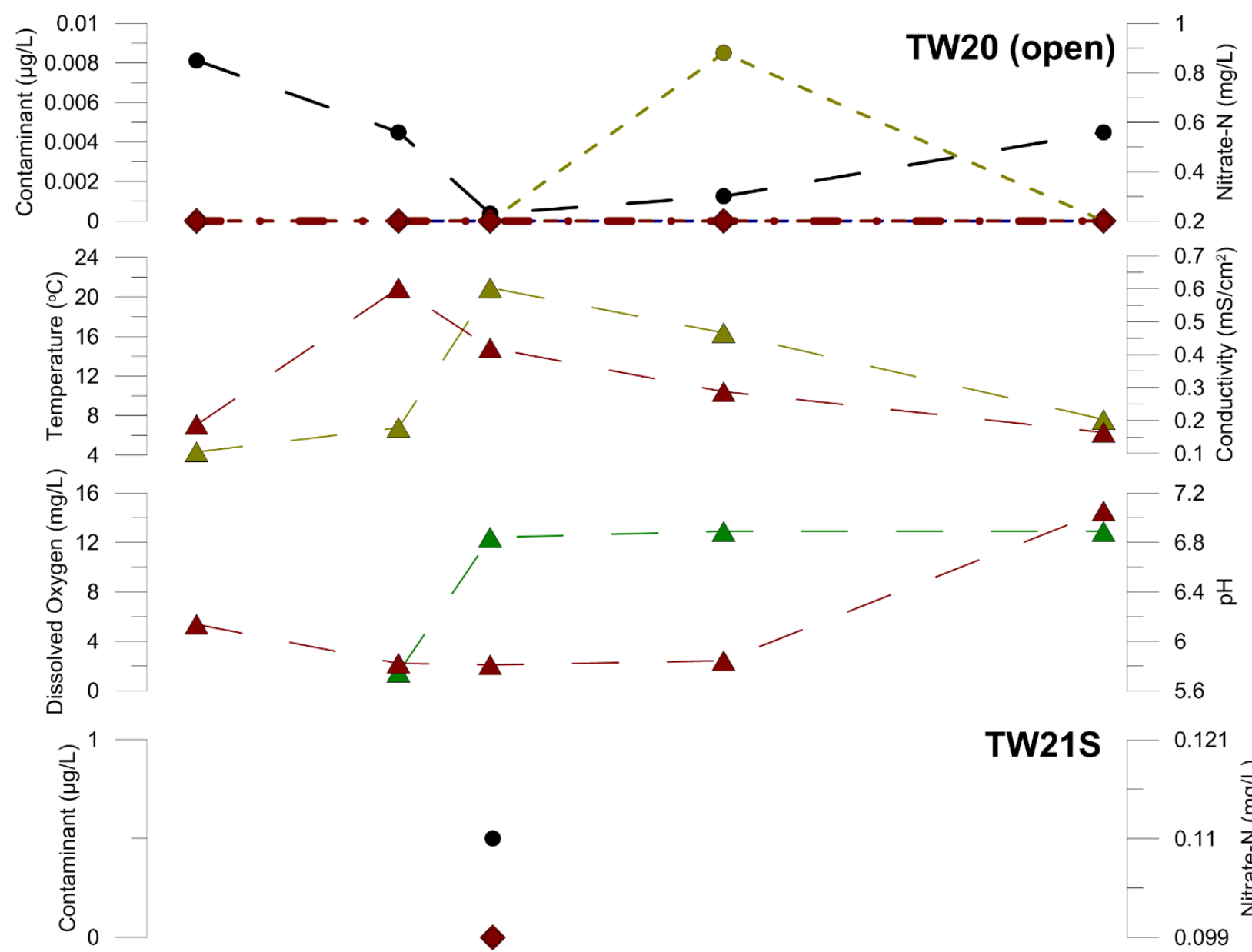

TW21S

0.121
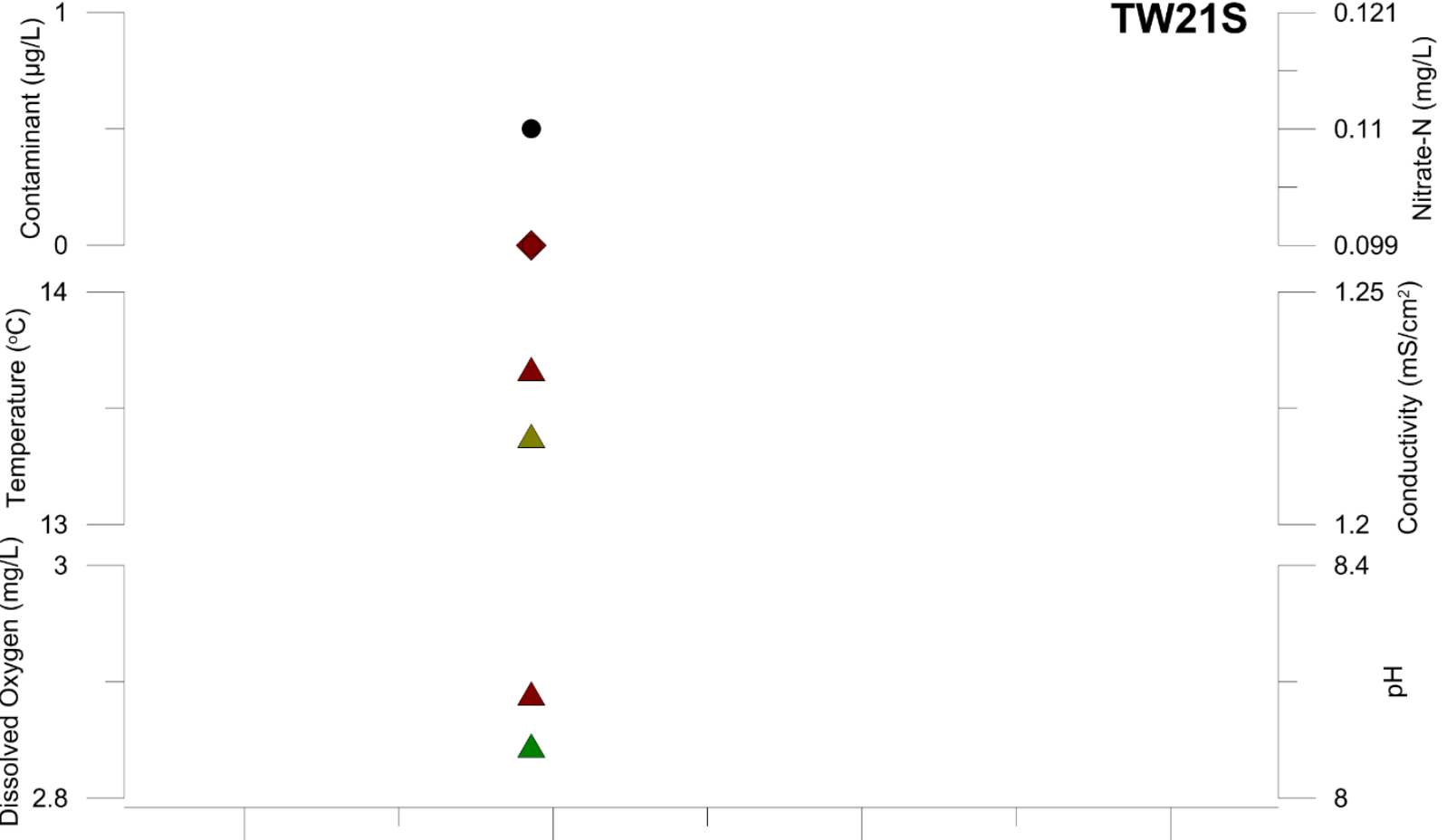

$\Delta$

$\triangle$

May 10, 2016

Aug 18, 2016

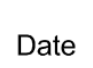

Nov 26, 2016

Mar 06, 2017

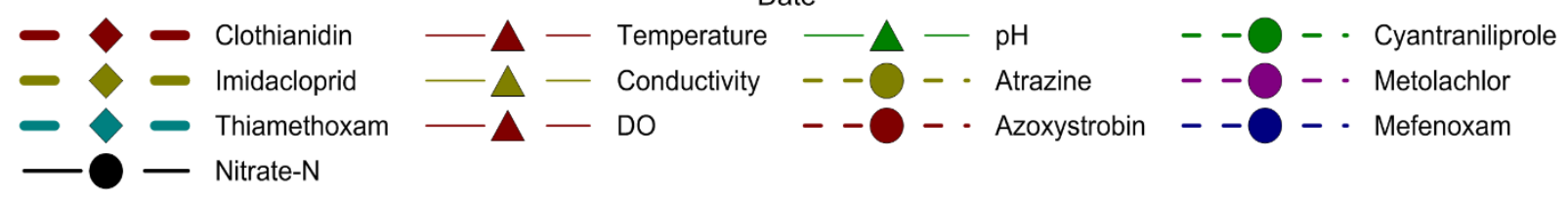



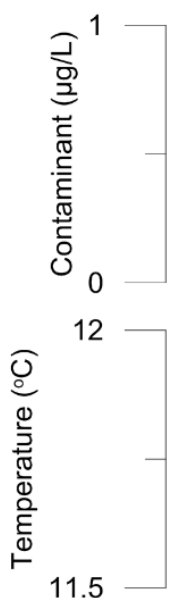

วิ 2.3

है 2.3

吕

จุ

밀

员 2.2

May 10, 2016
○

人

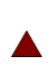

$\Delta$

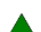

$\Delta$

Aug 18, 2016
TW21M
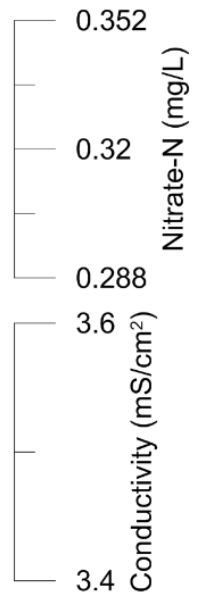

7.2

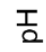

6.8




Appendix I - Sensitivity Analysis 
A sensitivity analysis was performed on the Hydrus 1D model for the Norfolk County research site. A summary of input parameters that were changed and the resulting output are seen in the below table. The sensitivity analysis was performed through calculating a relative sensitivity coefficient as follows:

$$
S_{R}=\frac{\left[\frac{F^{\prime}-F_{R E F}}{F_{R E F}}\right]}{\left[\frac{X^{\prime}-X_{R E F}}{X_{R E F}}\right]}
$$

Where

$S_{R}$ : Relative sensitivity;

F': Adjusted output;

FREF: Reference (original) output;

$X$ ': Adjusted parameter; and

$\mathrm{X}$ : Reference parameter.

\begin{tabular}{|c|c|c|c|c|c|c|}
\hline Parameter & $\begin{array}{l}\text { Reference } \\
\text { Parameter }\end{array}$ & $\begin{array}{c}\text { Reference } \\
\text { Output }\end{array}$ & $\begin{array}{l}\text { Adjusted } \\
\text { Parameter }\end{array}$ & $\begin{array}{c}\text { Adjusted } \\
\text { Output }\end{array}$ & $\begin{array}{c}\text { Relative } \\
\text { Sensitivity }\end{array}$ & Notes \\
\hline $\begin{array}{l}\text { Bulk Density } \\
\text { Mat } 1\end{array}$ & $1.60 \mathrm{E}+00$ & $4.00 \mathrm{E}-01$ & $1.60 \mathrm{E}+01$ & 4.00E-01 & $0.00 \mathrm{E}+00$ & \\
\hline $\begin{array}{l}\text { Bulk Density } \\
\text { Mat } 2\end{array}$ & $1.40 \mathrm{E}+00$ & 4.00E-01 & $1.40 \mathrm{E}+02$ & 4.00E-01 & $0.00 \mathrm{E}+00$ & \\
\hline $\begin{array}{l}\text { Bulk Density } \\
\text { Mat } 3\end{array}$ & $1.70 \mathrm{E}+00$ & $4.00 \mathrm{E}-01$ & $1.70 \mathrm{E}+02$ & $4.00 \mathrm{E}-01$ & $0.00 \mathrm{E}+00$ & \\
\hline $\begin{array}{c}\text { Dispersivity } \\
\text { Mat } 1\end{array}$ & $4.70 \mathrm{E}+00$ & $4.00 \mathrm{E}-01$ & $4.70 \mathrm{E}+02$ & $3.70 \mathrm{E}-01$ & $7.58 \mathrm{E}-04$ & $\begin{array}{c}\text { More } \\
\text { gradual } \\
\text { increase } \\
\text { before peak } \\
\text { More }\end{array}$ \\
\hline $\begin{array}{c}\text { Dispersivity } \\
\text { Mat } 2\end{array}$ & $9.40 \mathrm{E}+00$ & $4.00 \mathrm{E}-01$ & $9.40 \mathrm{E}+02$ & $3.70 \mathrm{E}-01$ & $7.58 \mathrm{E}-04$ & $\begin{array}{c}\text { gradual } \\
\text { increase } \\
\text { before peak }\end{array}$ \\
\hline $\begin{array}{c}\text { Dispersivity } \\
\text { Mat } 3\end{array}$ & $2.40 \mathrm{E}+01$ & 4.00E-01 & $2.40 \mathrm{E}+03$ & $3.20 \mathrm{E}-01$ & $2.02 \mathrm{E}-03$ & \\
\hline $\begin{array}{l}\text { Diameter of } \\
\text { soil grains }\end{array}$ & 1.06E-02 & $4.00 \mathrm{E}-01$ & $1.06 \mathrm{E}+01$ & $4.20 \mathrm{E}-01$ & 5.01E-05 & \\
\hline $\begin{array}{l}\text { Molecular } \\
\text { Diffusion }\end{array}$ & $1.00 \mathrm{E}-08$ & 4.00E-01 & $1.00 \mathrm{E}-04$ & $4.10 \mathrm{E}-01$ & $2.50 \mathrm{E}-06$ & \\
\hline $\begin{array}{l}\text { Kd Mat } 1 \text { (ie } \\
\% O M=20)\end{array}$ & $2.89 \mathrm{E}+00$ & 4.00E-01 & $2.46 \mathrm{E}+01$ & 4.10E-01 & 3.33E-03 & \\
\hline $\begin{array}{l}\text { Kd Mat } 2 \text { (ie } \\
\% O M=20) \\
\text { Liquid }\end{array}$ & $1.50 \mathrm{E}+00$ & 4.00E-01 & $2.46 \mathrm{E}+01$ & 4.10E-01 & $1.62 \mathrm{E}-03$ & \\
\hline $\begin{array}{l}\text { Degradation } \\
\text { Rate } \\
\text { Solid }\end{array}$ & 1.72E-02 & 4.00E-01 & $1.72 \mathrm{E}+01$ & 4.00E-05 & $1.00 \mathrm{E}-03$ & \\
\hline $\begin{array}{l}\text { Degradation } \\
\text { Rate }\end{array}$ & 1.27E-03 & 4.00E-01 & $1.27 \mathrm{E}+00$ & 4.10E-02 & 8.98E-04 & \\
\hline
\end{tabular}


As a result of the low relative sensitivity values obtained in this exercise, it was deemed unnecessary to repeat for the overburden at the Lanark County site due to the identical Hydrus 1D code and similar contaminant properties. However, further sensitivity exercises were performed on both Hydrus 1D models through adjusting the precipitation and evapotranspiration inputs by $+15 \%$ and $-15 \%$. The graphical outputs are seen below.
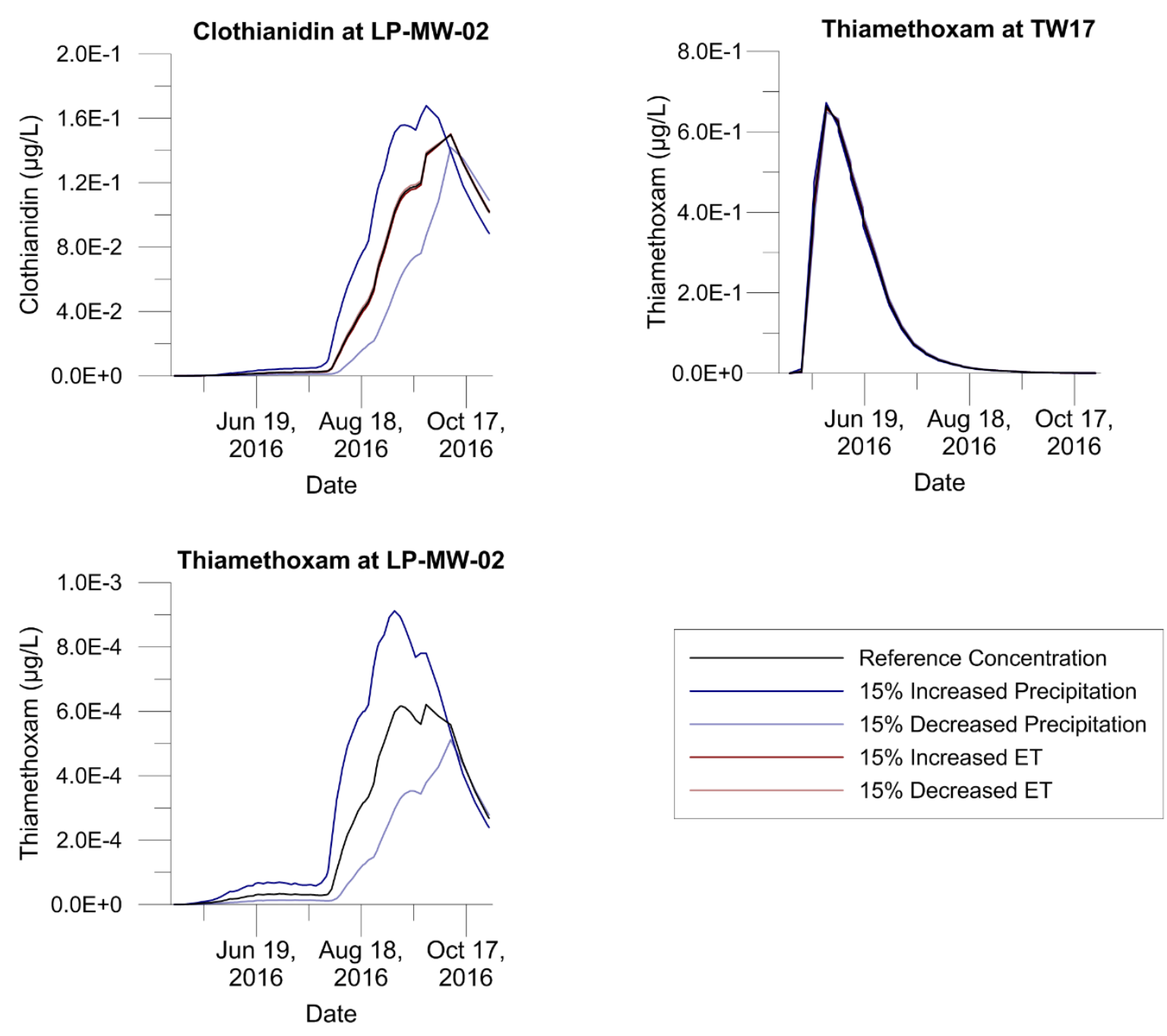


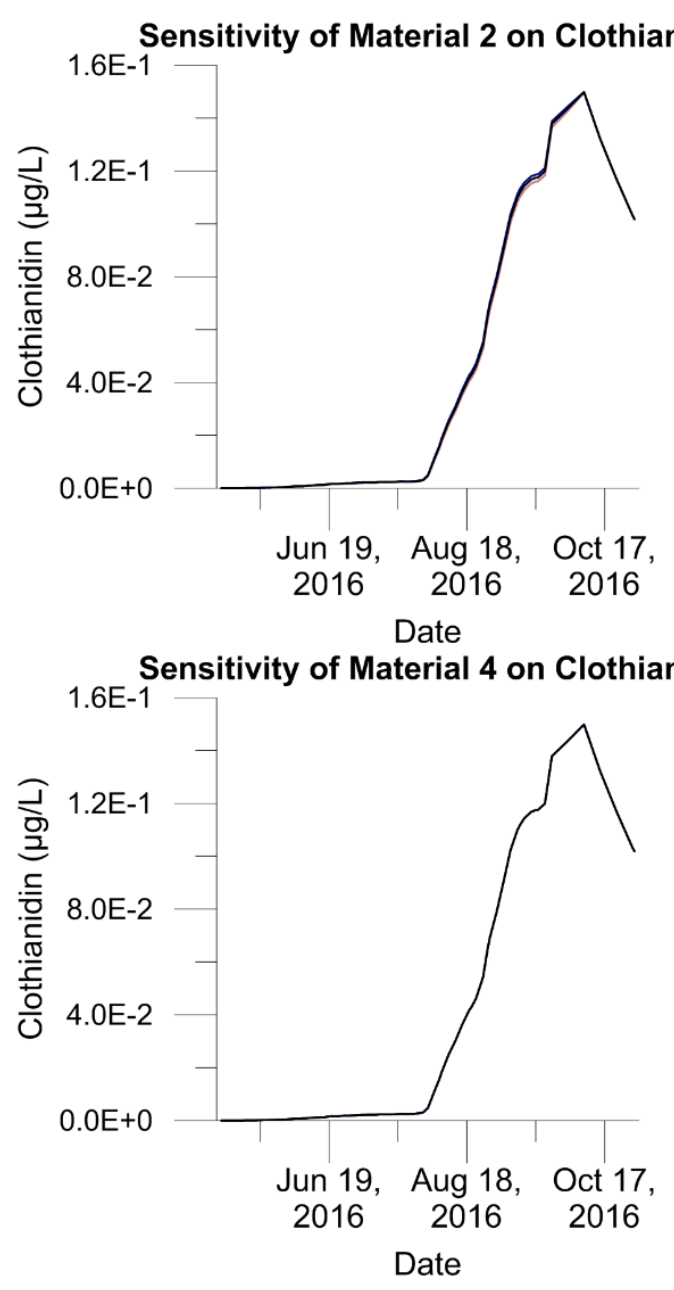

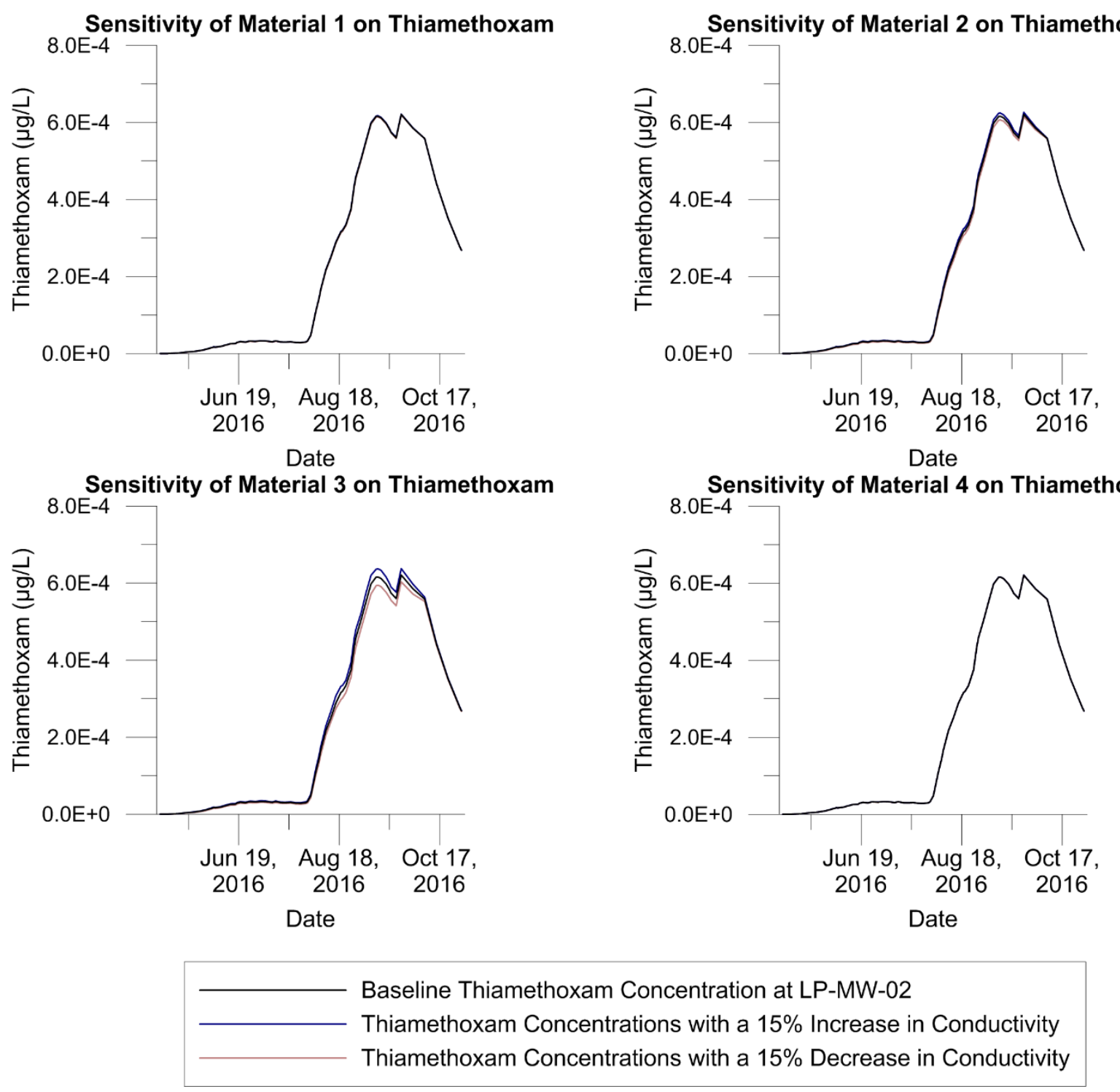

The above graphs show a sensitivity analysis that was performed on each of the four materials in Norfolk County. Material 1 extends from the ground surface to $0.5 \mathrm{mBGS}$, material 2 extends from 0.5 to $2.0 \mathrm{mBGS}$, material 3 extends from 2.0 to $10 \mathrm{mBGS}$, and material 4 extends from $10 \mathrm{mBGS}$ to $21 \mathrm{mBGS}$. All outputs are from the top of the groundwater table (10 mBGS). There are minor changes observed to the transport of thiamethoxam through the vadose zone when material 3 hydraulic conductivity is increased or decreased by $15 \%$. 


\begin{tabular}{cccc}
\hline Depth & $\begin{array}{c}\text { Original CLO } \\
\text { Inputs }(\mu \mathrm{g} / \mathrm{L})\end{array}$ & $\begin{array}{c}\mathrm{x7} \mathrm{CLO} \\
\text { Inputs } \\
(\mu \mathrm{g} / \mathrm{L})\end{array}$ & $\begin{array}{c}\mathrm{X9} \mathrm{CLO} \\
\text { Inputs } \\
(\mu \mathrm{g} / \mathrm{L})\end{array}$ \\
\hline 0 & 17.07 & 119.49 & 153.63 \\
8.75 & 1.26 & 8.82 & 11.34 \\
17.5 & 12.08 & 84.56 & 108.72 \\
26.25 & 7.43 & 52.01 & 66.87 \\
\hline
\end{tabular}

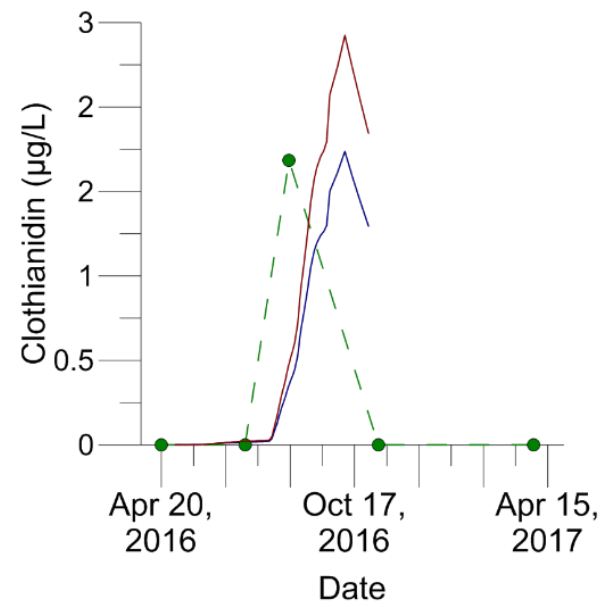

_ $\ldots$ Field Clothianidin Concentration at LP-MW-02

Modelled Clothianidin Concentration with $\times 7$ Concentration Inputs

Modelled Clothianidin Concentration with $\times 9$ Concentration Inputs

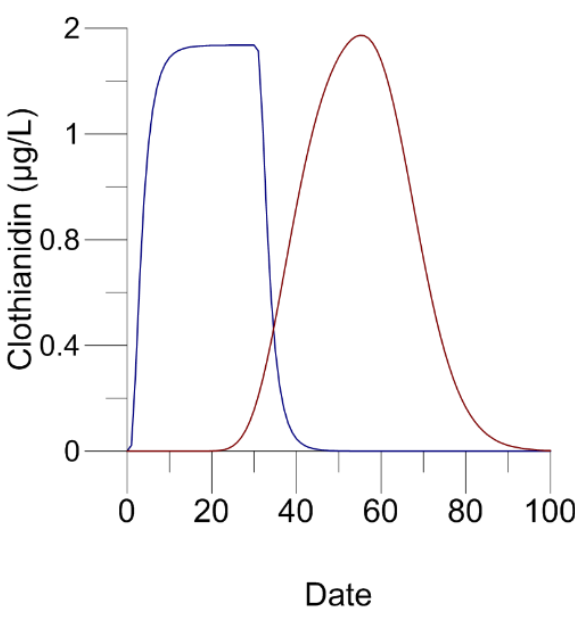

Modelled Clothianidin Concentration with $\times 7$ Concentration Inputs $10 \mathrm{~m}$ Downstream in Saturated Zone Modelled Clothianidin Concentration with $\times 9$ Concentration Inputs $100 \mathrm{~m}$ Downstream in Saturated Zone

The above graphs were developed through manipulating the model input concentration in order to match outputs to peak clothianidin concentrations that were found in the field. In order to match the highest field concentration to the modelled concentration $10 \mathrm{~m}$ downstream in the sandy aquifer, the clothianidin input to the Hydrus 1D model was increased by 7 . In order to match the field peak to the modelled peak $100 \mathrm{~m}$ downstream in the sandy aquifer, the input clothianidin concentration to the Hydrus 1D model was increased by 9 . 